\title{
UC-NRLF
}

|

В $3,371,536$ 


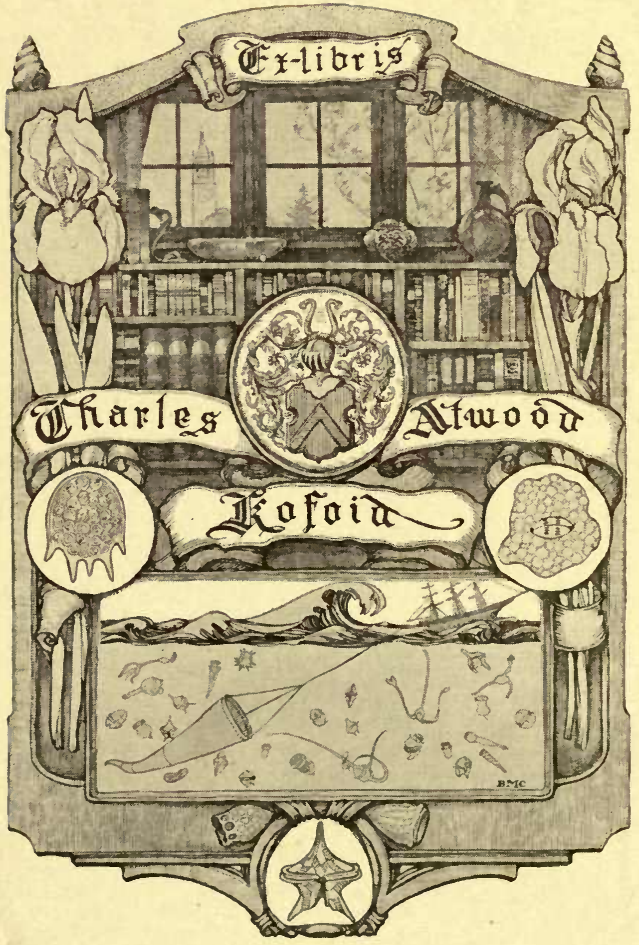



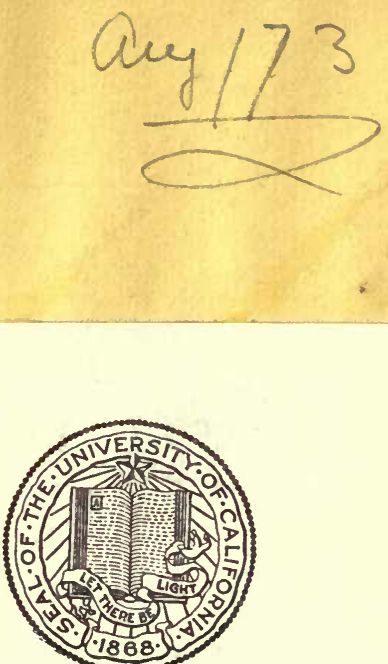

.

THE LIBRARY OF THE UNIVERSITY OF CALIFORNIA

PRESENTED BY

PROF. CHARLES A. KOFOID AND MRS. PRUDENCE W. KOFOID 


$$
\begin{aligned}
& 6^{5 t}+/ / 2 \\
& 4-2
\end{aligned}
$$


GEODEPHAGA BRITANNICA. 


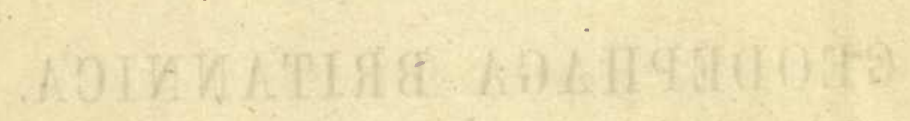




\title{
GEODEPHAGA BRITANNICA.
}

A MONOGRAPH

OF THE

\section{CARNIVOROUS GROUND-BEETLES}

\author{
INDIGENOUS TO THE
}

B R I T I S H IS L E S.

BY

JOHN FREDERIC DAWSON, LL.B.

$$
\text { L O N D O N : }
$$

JOHN VAN VOORST, PATERNOSTER ROW. 


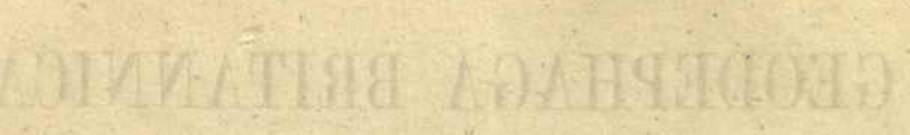

PRINTED BX TAYLOR AND FRANCIS,
RED LION COURT, FLEET STREET. 


\section{$K-Q L 591$

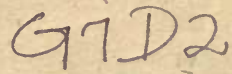 \\ Bul. \\ Lib.}

\section{PRELIMINARY OBSERVATIONS.}

In consequence of a suggestion made to me by several of my entomological friends and correspondents, I have been induced to undertake, and at length to publish, a specific arrangement of the Carnivorous Ground-Beetles indigenous to the British Isles, a group to which I have paid much attention. No small amount of confusion appears to have existed in their nomenclature, which has arisen from the circumstance of an undue importance having been assigned to varieties, differing merely in size and colour, which have either been formed into imaginary species, or have been mistaken for others which have never been found in Britain, the result of which has been that the total amount of actual species has been considerably overrated.

In order, if possible, to place their nomenclature and synonymy on a more satisfactory footing, I applied myself to a careful examination and comparison of the various-species contained in all the public and private collections to which I could gain access, especially in those of Messrs. Curtis and Stephens, those of the British Museum, of the Linnæan Society, and the Kirbian collections of the Entomological Society, by which means I have been enabled to arrive at a tolerably correct estimate of their actual value in point of numbers. Some of my more distant correspondents have likewise sent me their entire collections of Carabideous insects for examination, among which I may mention the late Rev. Mr. Rudd's specimens in the Museum of the York Philosophical Institution. The original examples on which Mr. Waterhouse founded the details of his Monograph on the British Notiophili, 
which was published some years ago in the Entomological Magazine, I have likewise had an opportunity of examining, and have the satisfaction of being able to state on his authority, that the opinion which he at that time entertained with regard to their supposed specific differences has since become materially modified, and does not now differ in any important particular from those which I have advanced respecting them. I have been enabled, moreover, through the attention of others, and especially through the facilities kindly afforded by M. Javet in his periodical visits to this country, to compare with continental types several of our more obscure and doubtful forms, all which has tended materially to facilitate my object. To my obliging correspondent, M. Jacquelin-Duval, I am particularly indebted for the careful consideration which he bestowed on my collection of indigenous Bembidia, types of which he had in his possession during the period in which he was engaged in preparing his Monograph 'De Bembidiis Europæis'; and which were returned to me accompanied by much useful information.

Some important notes on a portion of the Carabida contained in Mr. Stephens's cabinet were made by Dr. Schaum, during his first visit to England in 1846, which were communicated to me at that time and subsequently published in the Stettin Transactions, of which a translation appeared more recently in the 'Annals and Magazine of Natural History': to the general accuracy of those notes I am enabled to bear testimony; and to the kindness with which Mr. Stephens afforded me every facility at all times for making myself thoroughly acquainted with the contents of his cabinet, I have been indebted for the means of identifying the species and correcting their arrangement*.

I have been unwilling to reject any reputed indigenous species which I felt that I could reasonably retain, and yet, after full consideration, have been compelled to reduce their aggregate amount very considerably, either because many of them are evidently varieties of others, or because no sufficiently conclusive evidence exists to warrant their retention in the British Fauna. In the subfamily Bembidides, particularly, I have been compelled to reject about two-fifths as mere varieties or immature exarnples,

* Since Mr. Stephens's death his collections have become the property of the nation, and are now in the British Museum. 
which may satisfactorily be resolved into some one or other of the remainder. Equally unwilling have I been to record any as novel, until I had failed to procure its recognition. Of the several species described in this work as new, all have been submitted to the opinion of continental entomologists, with one or two exceptions, and returned as unknown; and whether the latter may ultimately prove to have been undescribed or not, I have thought it better to introduce them as species which are undoubtedly indigenous, than to pass them over without notice.

As an additional aid in determining the differences between certain closely allied species, some outlines are added representing those external parts of the insects in which the most material distinctions of character are to be found, which, as well as the dissections, and the entire figures of newly introduced species, have been carefully delineated by Mr. Westwood from typical examples.

I have confined my citations to a few only of the principal authorities, in preference to extending them, as I conceived unnecessarily, beyond the limits of what was requisite to identify the species. The references given to Mr. Stephens's works of those reputed British Carabida, of which no indigenous examples exist in any collection (and of which the supposed representatives contained in his cabinet must unquestionably be referred to other species), are to be considered as applicable to those supposed representatives, and not to the actual species of the authors, whose names he has assigned to them, except where it is otherwise stated: but this remark does not apply to those veritable species of continental authors, which are correctly designated by Mr. Stephens as British, because in some instances the descriptions given by our English author apply to the actual species whose names he has affixed to those descriptions, rather than to their supposed representatives contained in his collection. The reputed British species, above alluded to, will be found noticed under the respective heads to which they really belong, and need not here be enumerated: but besides these, there are a few others (not to mention such exotic insects whose claim to admission into the British Fauna has long been abandoned) which are not noticed in the body of this work, and of which no sufficiently 
authenticated examples exist in any collection, which may as well be here disposed of.

Lebia ephippium, Steph. Manual, App. p. 433. Doubtless imported.

Carabus agrestis, Creutz., et Lippii, Dahl. Said to have been found in Lincolnshire.

Nebria picicornis, Fab. Stated to have been captured by the Rev. F. W. Hope in Longmont Forest. Its natural habitat is on the muddy banks of rivers and lakes, and the locality in which it is reputed to have been found is so widely different from those which it naturally affects, that I am inclined to suspect it has been introduced into the British Fauna by mistake.

Helobia impressa, Newm. I have not seen this insect; it probably belongs to Nebria nivalis.

Licinus cassideus, Fab. Not indigenous; a specimen is reputed to have been found at Aldborough.

Epomis circumscriptus, Dufts. Not British; it is represented in the Stephensian cabinet by two Chlanii from the Cape, as stated by Dr. Schaum in the 'Stettin Transactions.'

Sogines punctulatus, Ill.

Cophosus elongatus, Sam.

Pterostichus fasciopunctatus, Fab.

$$
\text { Panzeri, Meg. }
$$

Cheporus metallicus, Fab.

Agonum Bogemanni, Gyll.

Amara municipalis, Dufts.

Zabrus obesus, Latr.

Pangus Scaritides, Sturm.

Peryphus Fellmanni, Gyll.

Lopha nana, Steph.

No example exists in any British Collection to represent the above species.

Although the present work has been undertaken merely with the view of furnishing a descriptive arrangement of the species of Geodephagous insects indigenous to the British Isles, yet it will be proper to offer some remarks on the Generic arrangement which I have employed, inasmuch as it differs from that which is ordinarily received by English entomologists.

It is evident that the principle upon which the Brachinida, Scaritida, Harpalida, and Bembidida have been erected into distinct families, and placed upon a footing of equal importance 
with the Cicindelida and Carabida, cannot be maintained, but that the most consistent and natural division will be found in Latreille's two grand families Cicindeletes and Carabici, which arrangement I have accordingly resumed under the terms Cicindelide and Carabida, the distinctive characters of which will be found stated; and I have furthermore divided the latter into five groups or subfamilies, according to the plan set forth by Mr. Westwood in his 'Introduction to the Modern Classification of Insects,' with this difference however, that I have transposed the third and fourth groups, considering it more desirable that the Harpalides should immediately precede the Bembidides; and the natural transition from Trechus to Bembidium be maintained through the intimate affinities which subsist between those remarkable insects Aëpys* marinus, Blemus areolatus, Lymnaum nigropiceum, and Cillenus lateralis; and I have placed Pelophila and the Elaphridea in their natural juxtaposition with Nebria, though by so doing, the foreign genus Homophron is further removed from the Hydrocantharides, to which at first view, and judging merely from its external structure, it would seem to be more nearly allied than it really is : in this arrangement $I$ have consequently followed, under certain modifications, Dejean, Erichson, Heer, Redtenbacher, and in fact most of the continental entomologists.

The first group (Brachinides) comprises all the genera which were comprehended in the family Brachinida of MacLeay and Stephens; and corresponds with Dejean's subfarnily Truncatipennes, or Ground-Beetles with the apex of their elytra truncate and not quite covering the abdomen; these also have the anterior tibiæ notched within before the apex and the anterior tarsi in the $\delta$ rarely dilated.

The second group (Scaritides) corresponds with the Scaritides of Dejean and the family Scaritida of MacLeay and Stephens, and comprises insects of a very remarkable form, being usually elongate and cylindrical, with their abdomen remote from the thorax with which it is connected by a narrow collar or neck; these have their elytra entire; their anterior tibiæ deeply notched within and generally expanded or palmated externally; the anterior tarsi being simple in both sexes.

* Properly Aëpys, ainvis altus pro profundus. 
The third group (Carabides) corresponds with the Simplicipedes of Dejean, and comprises the Carabida of MacLeay and Stephens and the Elaphrida of Stephens (Carabini and Elaphrini, Erichson). These have the elytra also entire; the anterior tibiæ entire and not notched; the anterior tarsi being more or less dilated in the $\delta$.

The fourth group (Harpalides) comprehends the Patellimanes, Feroniens and Harpaliens of Dejean, and corresponds with the Harpalide of MacLeay and Stephens; they have the elytra entire or very slightly emarginate before the apex; the anterior tibiæ notched within; and the anterior tarsi of the $\delta$ with from two to four joints at the base more or less considerably dilated, in some genera the intermediate tarsi being likewise dilated.

The fifth group (Bembidides) comprises the insects assigned by Dejean to his group Subulipalpes, with the exception of the genus Trechus (Blemus, Steph.), and corresponds with the Bembidiidae of Stephens. The insects which compose this group have their elytra entire ; the anterior tibiæ notched within; and the anterior tarsi of the $\delta$ with usually two joints dilated.

The generic characters employed in this work are chiefly borrowed and adopted from Erichson and Heer, or based upon Mr. Curtis's admirable dissections. The modern subdivisions of genera having proved unsatisfactory, being sometimes founded on almost imaginary differences, at any rate far from constant, are altogether rejected, and I have merely inserted the names of the subgenera in brackets for the convenience of those English entomologists who have been most accustomed to Stephens's arrangement, without meaning to attach to them any importance otherwise.

The Woodlands,

April 6, 1854. 


\section{REFERENCES TO AUTHORS.}

Ahrens, Archiv. Ahrens: Thon's Entomologisches Archiv. 1830. Faun. Eur. Fauna Insectorum Europæ. Ahrens et Germar. 1812 , \&c.

Babington, Ent. Trans. C. C. Babington in the Entomological Transactions, vol. i.

Bonelli, Obs. Ent. Bonelli, Observations Entomologiques. 1809.

Brull. Nat. Hist. Histoire naturelle des Insectes, par MM. Audouin et Brullé. (Coléoptères.) 1834, \&c.

Chaudoir, Carab. Carabiques de Crimée. Supplement to Enumération des Carabiques et des Hydrocanthares du Caucase, par M. de Chaudoir. 1846.

Clairv. Ent. Helv. Entomologie Helvétique, ou Catalogue des Insectes de la Suisse. 1798-1806.

Creutz. Ent.Ver. Creutzer, Entomologische Versuche. 1799.

Curtis, Ent. British Entomology, by J. Curtis. 1824, \&c.

Guide. Guide to an Arrangement of British Insects, by J. Curtis. 1838.

Davis, Loudon's Mag. N. H. Davis in Loudon's Magazine of Natural History, vol. v.

Dawson, Ann. Nat. Hist. Descriptions of new species of Coleoptera, by J. F. Dawson, in the Annals of Natural History, vol. iii. (2nd Series) 1849.

De Geer, Ins. Mérnoires pour servir à l'Histoire des Insectes, par De Geer.

Dej. Cat. Catalogue des Coléoptères de la Collection de M. le Comte Dejean. 1837. 
Schrank. En. Enumeratio Insectorum Austriæ indigenarum. Schrank. 1781.

Scop. Ent. Carn. Scopoli, Entomologia Carniolica. 1763.

Steph. Mand. Illustrations of British Entomology. Mandibulata. By J. F. Stephens. 1827-1835.

Steph. Manual. A Manual of British Coleoptera, by J. F. Stephens. 1839.

Ström. Act. Hafn. Norske Insecters beskrivelse med anmärkninge af H. Ström. Nye Saml. Danske Viden. Selsk. Skrift. ii. (1783.)

Sturm, D. F. Deutschlands Fauna. Käfer, von Jacob Sturm. $1805-1839$.

Thunb. Nov. Spec. Dissertatio Entomologica novas Insectorum species sistens, \&c., by C. P. Thunberg. Upsal, 1784.

Villers, Linn. Ent. Caroli Linnæi, Entomologia, Faunæ Suecicæ descriptionibus aucta Scopoli, Geoffroy, De Geer, \&c., curante et augente $\mathrm{C}$. de Villers. 1789.

Waterhouse, Ent. Mag. Monographia Notiophilon Angliæ, by G. R. Waterhouse, published in the Entomological Magazine, vol. i. 1833.

Wesmael, Bull. Acad. Wesmael, dans le Bulletin de l'Académie Royale des Sciences de Bruxelles. 1835.

Zimm. Gist. Faun. Monograph on Amara, in Gistl's Faunus. 1st band, 1st heft. Munchen, 1832, by Zimmermann. 


\section{T A B U L A}

\section{FAMILIARUM GENERUM AC SPECIERUM.}

\section{Page}

I. CICINDELID A. 1 CICINDELA

1. sylvatica

2. hybrida

3. maritima

4. campestris

5. germanica

II. CARABIDAE.

\section{(1. Brachinides)} DRYPTA

1. emarginata

1. melanura

\section{DEMETRIAS}

1. imperialis

2. atricapilla

3. unipunctata

\section{DROMIUS}

1. longiceps

2. linearis
3. agilis

4. quadrimaculatus

5. quadrinotatus

6. quadrisignatus

7. sigma

8. fasciatus

9. melanocephalus

10. glabratus

11. truncatellus

4 12. foveolus

13. obscuro-guttatus

14. quadrillum 4

4

\section{5}

5

1. crux minor

LEBIA

2. turcica

3. hæmorrhoidalis

5

6

6

7

7

7

8

1. crepitans
Page

8

9

10

10

11

12

12

13

13

14

14

15

16

17

17

18

(Lamprias) $\quad 18$

4. cyanocephala $\quad 19$

5. chlorocephala $\quad 19$

BRACHINUS 19

20

20 


\section{TARUS}

1. humeralis

2. axillaris

3. vaporariorum

1. Sycophanta

CALOSOMA

1. fasciolatus

POLYSTICHUS

24

LEISTUS

2. inquisitor

\section{(2. Scaritides)}

24

1. spinibarbis

2. fulvibarbis

3. montanus

4. ferrugineus

\section{CLIVINA}

1. fossor

5. rufescens

2. collaris

\section{DYSCHIRIUS}

NEBRIA

1. inermis

2. nitidus

3. politus

4. salinus

1. complanata

2. livida

5. obscurus

6. impunctipennis

7. thoracicus

29

8. jejunus

9. æneus

10. globosus

(3. Carabides)

(Helobia)

4. nivalis

\section{(Pelophila)}

49

5. borealis

1. uliginosus

2. cupreus

3. Lapponicus

4. riparius

\section{CYCHRUS}

33

1. rostratus

(Blethisa)

52

33

\section{CARABUS}

1. intricatus

2. catenulatus

3. monilis

4. arvensis

5. granulatus

6. cancellatus

7. clathratus

34

34

35

35

36

37

37

8. auratus

9. nitens

10. violaceus

11. convexus

12. glabratus

13. nemoralis

38

38

39

39

5. multipunctatus

53

53

NOTIOPHILUS 53

\section{1. aquaticus}

54

2. palustris

3. rufipes

54

4. semipunctatus

55

5. quadripunctatus

55

57

$$
\text { (4. Harpalides) } 57
$$

41

1. pilicornis

PANAGEUS

58

58

58

59 
xvii

$\begin{array}{lrcr} & \text { Page } & \text { Page } \\ \text { BADISTER } & 59 & \text { 7. micropterus } & 78 \\ \text { ustulatus } & 60 & \text { 8. nubigena } & 79 \\ \text { pustulatus } & 60 & \text { SYNUCHUS } & 80 \\ \text { (Trimorphus) } & 61 & \text { 1. vivalis } & 80\end{array}$

3. peltatus

4. humeralis

61

LICINUS

1. depressus

2. Silphoides

62

62

63

OÖDES

1. Helopioides

\section{CHLAENIUS}

1. sulcicollis

2. holosericeus

3. nigricornis

4. agrorum

5 . vestitus

CALLISTUS

1. lunatus

\section{POGONUS}

1. luridipennis

2. chalceus

3. littoralis

PATROBUS

1. excavatus

2. septentrionis

PRISTONYCHUS

1. terricola

SPHODRUS

1. leucophthalmus

CALATHUS

1. piceus

2. Cisteloides

63

64

64

64

65

66

67

67

68

68

ANCHOMENUS

81

(Platynus)

1. junceus

81

81

(Anchomenus)

2. livens

3. dorsalis

4. pallipes

82

5. oblongus

83

84

84

6. marginatus

(Agonum)

84

7. sexpunctatus

8. modestus

9. fulgens

85

86

87

87

88

89

69 13. atratus 89

69 14. fuliginosus $\quad 90$

70 15. gracilis 91

70 16. scitulus 91

71 17. micans 92

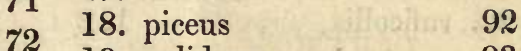

72 19. pelidnus 93

72 20. Thoreyi 94

73 21. quadripunctatus $\quad 95$

73 OLISTHOPUS 95

73 1. rotundatus 95

74. PTEROSTICHUS 96

74. (Poecilus) $\quad 97$

74 1. cupreus 97

$\begin{array}{lll}75 & \text { 2. dimidiatus } & 97\end{array}$

3. flavipes

75

4. fuscus

3. lepidus

98

5. mollis

76

6. melanocephalus

77

$77 \quad 4$ striola

(Abax) $\quad 99$ 
xviii

$\begin{array}{ll}\text { (Pterostichus) } & 100 \\ \text { 5. niger } & 100 \\ \text { 6. parumpunctatus } & 100\end{array}$

Page

3. acuminata

Page

(Platysma) $\quad 101$

4. trivialis

118

119

5. spreta $\quad 119$

6. vulgaris 120

7. oblongo-punctatus

7. communis

121

101

8. picimanus

(Adelosia) 102

8. curta

121

9. familiaris $\quad 122$

102

10. lucida

122

11. tibialis 123

(Steropus)

9. madidus

103

103

10. Ethiops

103

12. strenua

13. plebeia

124

124

(Omaseus)

11. aterrimus

104

14. ingenua

(Celia)

125

104

12. Orinomus

13. melanarius

105

14. nigrita

106

15. anthracinus

16. gracilis

106

17. minor

107

108

18. vernalis

(Argutor)

19. inæqualis

20. erythropus

15. oricalcica

125

125

21. strenuus

109

109

110

110

111

(Platyderus)

22. ruficollis

112

112

1. pumicatus

STOMIS

113

113

BROSCUS

113

1. cephalotes

114

MISCODERA

115

1. arctica

115

2. ZABRUS

115

1. piger

AMARA

1. obsoleta

116

116

2. similata

(Acrodon)

126

16. brunnea

(Percosia)

17. patricia

(Bradytus)

18. consularis

19. apricaria

20. fulva

(Curtonotus)

21. spinipes

22. convexiuscula

ANISODACTYLUS 131

1. binotatus

2. pœeciloides

131

131

DIACHROMUS 132

1. germanus

132

HARPALUS

133

(Ophonus) 133

1. sabulicola

133

2. obscurus

3. azureus

4. punctatulus

134

5. cordatus

134

135

6. rupicola 
xix

Page

7. puncticollis $\quad 137$

8. cribellum 138

9. pubescens 138

10. obsoletus

139

(Harpalus) 139

11. ruficornis

12. æneus

13. honestus

14. sulphuripes

15. cuniculinus

16. luteicornis

17. attenuatus

18. atricornis

19. Wollastoni

20. discoideus

21. fulvipes

22. rubripes

23. cupreus

24. depressus

25. tardus

26. melancholicus

27. serripes

28. anxius

29. neglectus

139

140

141

141

142

143

2. cognatus

Page

3. fulvus

163

4. collaris

164

5. similis

165

30 . vernalis

MASOREUS

143

144

144

145

146

147

148

148

149

150

150

151

152

152

153

1. Wetterhallii

153

STENOLOPHUS 154

1. Teutonus

2. Skrimshiranus

154

3 . vespertinus

155

4. elegans

5. consputus

6. dorsalis

\section{TRECHUS}

165

1. discus

165

2. micros 166

3. longicornis $\quad 167$

4. rubens

5. lapidosus

167

6. incilis

168

7. minutus

168

8. secalis

(Epaphius)

170

$\begin{aligned} \text { AËPYS } & 170 \\ & 170\end{aligned}$

1. marinus

171

2. Robinii

171

(5. Bembidides) 172 BLEMUS 172

1. areolatus $\quad 173$

LYMN EUM $\quad 173$

1. nigxopiceum $\quad 174$

BEMBIDIUM 174

(Cillenus) $\quad 175$

1. laterale

175

155

156

157

158

7. meridianus

8. derelictus

159

159

9. flavicollis

160

10. luridus

160

11. exiguus

161

BRADYCELLUS

162

1. placidus

162

(Tachys)

175

2. scutellare

3. bistriatum

175

4. obtusum

176

177

(Ocys) 177

5. quinquestriatum $\quad 177$

6. rufescens 178

(Philocthus) , 179

7. biguttatum $\quad 179$

8. æneum 180

9. guttula 181 


\section{Pag}

10. femoratum

11. Bruxellense

12. concinnum

13. littorale

14. fluviatile

15. lunatum

16. saxatile

17. testaceum

18. decorum

19. Stomoides

20. monticulum

21. nitidulum

22. affine

23. tibiale

24. prasinum

(Notaphus)

25. flammulatum

26. ustulatum

27. obliquum

28. rupestre

29. fumigatum

30. ephippium

31. assimile

32. Clarkii
181

181

182

183

184

184

185

185

186

187

188

189

190

190

191

192

193

193

194

195

196

197

197

198

199
Page

200

33. lampros $\quad 200$

34. Schuppelii 201

35. gilvipes 201

36. pusillum 202

(Lopha) 203

37. doris 203

38. normannum 204

39. articulatum 205

40. quadriguttatum 205

41. callosum 206

42. quadrimaculatum 207

- (Bembidium) 207

43. bipunctatum 207

44. velox 208

45. pallidipenne 209

46. paludosum 210

(Tachypus) 211

47. flavipes

211

48. pallipes

211 


\section{GEODEPHAGA BRITANNICA.}

\section{COLEOPTERA.}

\section{GEODEPHAGA, MacLeay.}

Mandibulæ corneæ; palpi sex, quatuor maxillares, duo labiales, palpi maxillares externi 4-articulati, interni 2 -articulati; antennæ filiformes rarò submoniliformes; pedes cursorii ; tarsi omnes 5-articulati.

\section{Fam. 1. CICINDELID E.}

Mandibulæ acutè dentatæ; maxillæ ungue corneo, articulato terminatæ; palpi labiales articulis quatuor, basilari e stipite libero efformato; ligula cornea, inflexa, paraglossis nullis; mentum breve. Pedes longi, tibiis nunquam emarginatis. Cicindeletes, Latr. Gen. Crust. et Ins. 1. 173.

\section{Genus 1. CICINDELA, $L$.}

Mentum dente medio prominulo, acuto. Tarsi antici maris articulis tribus dilatatis, linearibus, subtus densè spongiosis.

1. C. sylvatica : nigro-subanea, elytris lunula humerali fasciâ obliquâ sinuatá abbreviatá punctoque marginali ante apicem albis.

Linn. F. S. 748.-Fab. S. El. 1. 235.-Gyll. Ins. Suec. 2. 4.Sturm, D. F. 7. 114.-Dej. Spec. 1. 71 ; Icon. 1. 29. pl. 3.Steph. Mand. 1. 7, et Manual, p. 5.-Erichson, Käfer, 2.-Heer, Faun. Helv. 3.

Bronze with a purplish tinge. Head finely striated and granulated; upper lip black, and more acuminated than in others of the genus, with an elevated longitudinal line in the centre 
terminated by a sharp tooth; antennæ fuscous with the four joints at the base coppery. Thorax rather wider than the head, scarcely narrowed behind; scutellum small, fuscous black. Elytra oblong, about double the width of the thorax, deeply and irregularly foveated near the suture and rugose-punctate throughout, having a small white spot on the shoulders, an oblique fascia rather behind the middle, and a roundish spot just before the apex, none of them, except the humeral one, touching the margin : underside of the legs and body clothed with white pile and their surface greenish blue, sides of the thorax and breast coppery. Length $7-8$ lines.

Abundant on sandy heaths; Cobham; Ripley; Weybridge; Christchurch; Manton Common near Brigg.

\section{C. hybrida : fusco-subanea, elytris lunula humerali apicalique fasciâque mediá sinuatâ abbreviatá albis.}

Linn. F. S. 747.-Fab. S. El. 1. 234.-Gyll. Ins. Suec. 2. 3.Dej. Spec. 1. 64 ; Icon. 1. 19. pl. 2.-Steph. Manual, p. 5.Erichson, Käfer, 2.

C. aprica, Steph. Mand. 1. 8.

C. riparia, Steph. Mand. 1. 9. pl. 1.

C. sylvicola, Curtis, Ent. pl. 1.-Steph. Mand. 1. 10, et Manual, p. 5.

Brownish (or greenish) bronze with purplish tints, head and thorax coppery, with the elytra green in less frequent individuals, but more generally fuscous. Head with an oblong green fovea on each side in front, very finely punctured and striated; upper lip yellowish white, with a minute tooth in the middle; antennæ fuscous, with the four joints at the base green or coppery. Thorax quadrate, scarcely narrowed behind, sides with long white pile, the transverse impressions on the anterior and posterior margins brilliant coppery red, bordered by a fine green line; scutellum large and much pointed. Elytra more coarsely granulated all over than in campestris, each with three white spots disposed thus, one lunular spot on the shoulder sometimes interrupted, one central band sinuated behind and denticulated in front not touching the outer margin and terminating in a roundish spot before reaching the suture, and a third on the margin before the apex and reaching to the tip of the suture; body beneath purplish green, with the breast and sides of the thorax coppery red; legs purplish copper, very pubescent, with the joints and tarsi purplish green. Length $6-7$ lines.

The insect described by Mr. Curtis as sylvicola is a green example of hybrida. The original representative of sylvicola, Meg., is by most entomologists considered a distinct species and is a 
larger insect, but is not found in Britain. Abundant on the sandy coasts of Lancashire and North Wales.

\section{C. maritima : fusco-subæenea, elytris lunula humerali apicalique fasciáque mediâ retrorsùm valdè flexuosá abbreviatá albis.}

Dej. Spec. 1. 67 ; Icon. 1. 22. pl. 3.-Steph. Manual, p. 5. C. hybrida, Steph. Mand. 1. 8.

In structure this species is similar to hybrida, but is usually smaller and more slender; in colour more variable, being more or less coppery, purplish, olivaceous, or lighter green. The spots on the elytra chiefly distinguish it, the humeral one being larger, and the central band considerably deflexed. Length 6 lines.

It is a maritime species, and found in profusion on the sandy coasts of Devonshire, Dorset and South Wales, and between Christchurch and Bournemouth, Hants ; and in countless multitudes on the shore near Burnham Market, Norfolk, in July and Angust.

\section{C. campestris : viridis, elytris punctis quinque marginalibus} sextoque discoidali albis.

Linn. F. S. 746.-Fab. S. El. 1. 233.-Gyll. Ins. Suec. 2. 2.Sturm, D. F. 7. 103.-Dej. Spec. 1. 59; Icon. 1. 16. pl. 2.Steph. Mand. 1. 11, et Manual, p. 5.-Erichson, Käfer, 2.Heer, Faun. Helv. 1.

Light green or bluish green. Head large, pilose, punctured and wrinkled; forehead deeply excavated, sides of the head striated with golden purple; upper lip with a minute tooth in the middle, and together with the base of the mandibles yellowish white; antennæ with four joints at the base purplish or reddish copper, the rest fuscous. Thorax short, narrowed behind, anterior and posterior margins rich golden red; scutellum small and red. Elytra ovate, much wider than the thorax, finely shagreened throughout, the suture and apex brassy, each with six round white spots; abdomen brilliant green, with the sides of the thorax and breast fiery copper; legs densely pilose, coppery, with the tarsi brassy green. Length 6 lines.

Very common both inland and on the coast.

5. C. germanica : viridis, cyanea vel nigricans, elytris puncto humerali maculâ marginali lunulâque apicali albis.

Linn. S. N. 1. 657.-Fab. S. El. 1. 237.-Dej. Spec. 1. 138 ; Icon. 1. 49. pl. 6.-Sturm, D. F. 7. 106.-Steph. Mand. 1. 11, et Manual, p. 5.-Erichson, Käfer, 3.-Heer, Faun. Helv. 4.

Bright green, bluish green, olivaceous or obscure black. Head 
as large as the thorax, finely granulated and striated; upper lip with a small tooth, and together with the mandibles externally white; antennæ with four basal joints coppery. Thorax long, narrow and cylindric, finely granulated; scutellum rather small. Elytra oblong, rather narrowed in front, widest behind the middle, with a small white spot on the humeral angle, an oblong one near the margin about the middle, and a minute one at the apex; underside brilliant purplish green, sides of the thorax and breast coppery; legs greenish, with the tibiæ testaceous. Length 5 lines.

Local ; but found in profusion near Charmouth and Swanwich, Dorset; Black Gang Chine, Isle of Wight, \&c. Unlike its congeners, it does not make use of its wings to effect its escape, but runs with amazing rapidity.

\section{Fam. 2. CARABID E.}

Mandibulæ firmæ, non aut levitèr dentatæ ; maxillæ apice arcuatæ, ungue fixo terminatæ; palpi labiales articulis tribus, stipite raro libero; ligula porrecta, cornea, paraglossis aucta. $\mathrm{Ca}$ rabici, Latr. Gen. Crust. et Ins. 1. $17 \%$.

\section{Subfam. 1. Brachinides, Westwood.}

\section{Genus 1. DRYPTA, Fabricius.}

Mentum maximum corneum. Ligula elongata, setis tribus longis ornata; paraglossis brevibus, acutis, apice liberis. Palpi articulis ultimis incrassatis, subsecuriformibus. Mandibulæ porrecta, elongata, uncinatc. Labrum breve, transversum, apice bisinuatum. Tarsi antici maris articulo primo levitèr dilatato, ultimo bifido.

1. D. emarginata : viridi-carulea, ore antennis pedibusque rufis.

Fab. S. El. 1. 230.-Dej. Spec. 1. 183 ; Icon. 1. 66. pl. 7.Steph. Mand. 1. 13, et Manual, p. 6.-Curtis, Ent. pl. 454.Heer, Faun. Helv. 6.

This elegant species is bright green or blue-green above and beneath. Head thickly punctured; eyes black and prominent; mandibles, palpi and antennæ red, the apex of the first joint of the latter, and a ring round the second and third black. Thorax elongate, rather narrowed behind, somewhat cylindric, with a central longitudinal line, and thickly punctured. Elytra wide, the shoulders rounded, dilated behind the middle, slightly notched at the apex, distinctly punctate-striated, interstices punctured, villose; legs red, tarsi sometimes pitchy. Length 4 lines. 
It is very rare in England. In 1815 several examples were captured near Hastings and Faversham; since which time it does not seem to have occurred till 1845, when I captured three specimens at Luccombe in the Isle of Wight, from the crevices of a clay bank, and for several succeeding seasons met with it sparingly during the months of March and April in the same locality. It has been found also at Lyme Regis, Dorset, by Mr. F. Walker.

\section{Genus 2. ODACANTHA, Paykull.}

Mentum dente medio integro. Ligula apice rotundata; paraglossis membranaceis, apice prominulo, ligulam haud superantibus. Palpi articulo ultimo acuminato. Tarsi articulo quarto integro; unguiculis simplicibus.

1. O. melanura: viridi-cyanea, antennis basi pectore pedibus elytrisque testaceis, his apice geniculisque nigro-cyaneis.

Attelabus melanurus, Linn. S. N. 2. 620.

- Odacantha melanura, Payk. Faun. 1. 169.-Fab. S. El. 1. 228.-Gvll. Ins. Suec. 2. 177.-Dej. Spec. 1. 176 ; Icon. 1. 63. pl. 7.- Steph. Mand. 1. 14, et Manual, p. 6.-Curtis, Ent. pl. 227.-Erichson, Käfer, 27.

Head black and shining, very large and dilated on each side about the middle where the eyes are placed, having behind the latter an oblong fovea; the first, second and third joints of the antennæ red, the rest dusky. Thorax bluish green, long, cylindric, deeply punctured. Elytra elongate, rounded at the shoulders, sides parallel, apex truncated obliquely, reddish testaceous with the apex shining blue-black; body beneath bluish green, with the breast red; legs red, the joints and tarsi black. Length 3 lines.

This insect is extremely abundant in the fens of Cambridgeshire and at Whittlesea Mere among the sedge and refuse in May, June, September and October. It is found also, as Mr. Stephens informs us, at Horning and Fakenham, and on the banks of the river Yare in Norfolk, and at Crwmllyn Bog near Swansea.

\section{Genus 3. DEMETRIAS, Bonelli.}

Mentum dente medio integro. Ligula apice rotundata; paraglossis membranaceis, ei aqualibus, apice singulatim rotundatis. Palpi articulo ultimo acuminato. Tarsi articulo quarto bilobo ; unguiculis pectinatis. 
1. D. imperialis : pallida, capite pectoreque nigro-piceis, thorace rufo ferrugineo, postice angustato, elytris obsoletè striatis, suturâ fuscâ in medio dilatatâ cùm maculâ marginali posteriore ramo arcuato obliquo connexá.

Dromius imperialis, Germ. Spec. Nov. 1. 1.

Demetrias imperialis, Sturm, D. F. 7. 63.-Dej. Spec. 1.229; Icon. 1. 101. pl. 14.-Steph. Mand. 1. 176, et Manual, p. 6. Lebia atricapilla, var. $c$, Gyll. Ins. Suec. 2. 188. Aëtophorus imperialis, Redt. Faun. Aust. 75.

Elongate, depressed, pale testaceous. Head black, large, narrowed before and behind. Thorax rusty red, elongate heartshaped, much contracted behind. Elytra shorter and wider than in the two following species, shoulders rounded, sides slightly sinuated before the middle, then dilated till just before the tip, much depressed, striated, the strix indistinctly punctured, and with four deeper impressions, pale testaceous and transparent so as to show the wings beneath, the suture fuscous till just before the middle, when the dark colour dilates and forms a lozengeshaped spot, and on each side near the extremity of the outer margin is another spot of the same colour, sometimes connected with the former by an oblique line; legs red. Length $2 \frac{1}{4}$ lines.

To receive this insect a new genus (Aëtophorus) has been created by Dr. Schmidt (Stettin Ent. Zeit. 1848, p. 388).

This species appears to have become very scarce in England, though formerly it was far from uncommon in the fens of Cambridgeshire and Huntingdonshire.

2. D. atricapilla: pallida, capite nigro, thorace rufo, elytris obsoletè striatis, immaculatis.

Carabus atricapillus, Linn. S. N. 2. 673.

Lebia atricapilla, Gyll. Ins. Suec. 2. 188.

Demetrias atricapillus, Dej. Spec. 1. 231.-Steph. Mand. 1. 15, et Manual, p. 6.-Erichson, Käfer, 28.-Heer, Faun. Helv. 8.

D. elongatulus, Dej. Spec. 1. 232 ; Icon. 1. 104. pl. 14.

D. obscurus, (Newman) Steph. Mand. 5. 366.

Linear-elongate, pale testaceous. Head black, crown smooth and shining, with the sides punctured; mandibles, palpi and antennæ red. Thorax red, heart-shaped, posterior angles rather acutely prominent, base with two foveæ. Elytra oblong, shoulders rounded, sides nearly straight or very little wider behind, the apex truncate, obsoletely striated, some of the interstices at the base and next the suture with distinct punctures; legs pale testaceous. Length 2 lines.

Generally distributed. 
3. D. unipunctata : pallida, capite nigro, thorace rufo, elytris obsoletè punctato-striatis, testaceis, suturâ maculáque ante apicem plus minùs dilatatá infuscatis.

Dromius unipunctatus, Germ. Spec. Nov. 1. 2.

Demetrias unipunctatus, Sturm, D. F. 7. 61.-Dej. Spec. 1. 230 ; Icon. 1. 102. pl. 14.-Heer, Faun. Helv. 8.

D. monostigma, Curtis, Ent. pl. 119.-Steph. Mand. 1. 15, et Manual, p. 6.

Lebia atricapilla, var. c, Gyll. Ins. Suec. 2. 188.

Linear-elongate, narrower than atricapilla, ferruginous red. Head black, smooth and shining, less wide than in the preceding species and less produced in front. Thorax after the same manner. Elytra narrower, finely striated, the striæ obsoletely punctured, and with four deeper impressions as in imperialis; suture and a round spot behind rusty brown; legs pale testaceous. Length 2 lines.

This species is extremely abundant in the fens of Cambridgeshire and Huntingdonshire both in spring and autumn, among sedge and at the roots of herbage. I have found it also at the roots of the tall wiry grass which grows on the sand-hills at Sandwich, Kent. Mr. Stephens informs us that it is found at Swansea and at South Creek, Norfolk.

\section{Genus 4. DROMIUS, Bonelli.}

Mentum dente medio nullo. Ligula una cùm paraglossis sub. coriaceis, rotundata. Palpi articulo ultimo acuminato. Tarsi articulo quarto integro; unguiculis simplicibus.

1. D. longiceps : elongatus ; capite elongato-ovato, nigro-piceo, thorace rufo-testaceo, elytris obsoletè striatis, pallidis, suturâ infuscatâ; antennis pedibusque pallidis.

Dej. Spec. 2. 450 ; Icon. 1. 106. pl. 11.-Babington, Ent. Trans. 1.88.-Steph. Mand. 5.367, et Manual, p.7.-Erichson, Käfer, 29.

Linear-elongate. Head pitchy black and elongate, narrowed before and behind, and obsoletely punctured throughout, having an oblong fovea between the eyes ; the latter large, but not prominent; mouth, palpi and antennæ testaceous. Thorax widest in front, longer than broad, the anterior angles rounded, sides narrowed behind and the margins elevated, especially at the posterior angles which are obtuse, the colour testaceous red, the dorsal line interrupted before it reaches the base, and the disk otherwise marked with a few faint transverse wrinkles; scutellum large and long, with its sides waved. Elytra narrowed and 
rounded at the shoulders, widest behind the middle, sides almost linear, much elongated, obsoletely striated, pale testaceous, with the suture fuscous, the obscure colour gradually widening towards the apex till it joins a large and often roundish spot of the same colour just before the extremity; legs pale testaceous. Length $2 \frac{1}{2}$ lines.

This rare species may readily be recognized by its very elongate form and its oblong head. It was first captured in this country at Madingley Wood, near Cambridge, in 1831, and has been occasionally found since in the sedge-boats on the river Cam. In July 1847 I secured three specimens, and in September 1850 a fourth among herbage in Holme Fen, not far from Whittlesea Mere.

2. D. linearis : elongatus, rufo-testaceus; elytris punctato-striatis, apice infuscatis; antennis pedibusque pallidis.

Carabus linearis, Oliv. Ent. 3. 35. 111.

Lebia linearis, Gyll. Ins. Suec. 2. 187.

Dromius linearis, Dej. Spec. 1. 233 ; Icon. 1. 107. pl. 11.Sturm, D. F. 7. 42.-Steph. Mand. 1. 25, et Manual, p. 7.Erichson, Käfer, 28.-Heer, Faun. Helv. 9.

Linear-elongate, narrow, testaceous red. Head large, smooth behind, longitudinally strigose in front, dusky, sometimes black; eyes black; mouth, palpi and antennæ testaceous. Thorax cordate, narrowed behind, moderately convex, with a fine dorsal furrow, and a fovea near each hinder angle. Elytra elongate, shoulders rounded, sides linear, punctate-striated, apex obscure ; legs pale testaceous. Length $2 \frac{1}{4}$ lines.

Very common.

3. D. agilis : oblongus; capite thoraceque ferrugineis; elytris fuscis, subtiliter striatis, seriebus duabus punctorum impressorum; antennis pedibusque pallidis.

Carabus agilis, Fab. Mant. 1. 204 (1787); S. El. 1. 185.Payk. Mon. 102 (1790).

Lebia agilis, Gyll. Ins. Suec. 2. 184.-Dufts. Faun. 2. 251.

Dromius agilis, Dej. Spec. 1. 240 ; Icon. 1. 118. pl. 12.Sturm, D. F. 7. 36.--Steph. Mand. 1.21, et Manual, p. 6.Erichson, Käfer, 30.-Heer, Faun. Helv. 11.

D. meridionalis, Dej. Spec. 1. 242.-Steph. Mand. 1. 16, et Manual, p. 6.

Var. $\beta$. elytris macula pallida ornatis.

Carabus fenestratus, Fab. S. El. 1.209.-Sturm, D. F. 7.168.Steph. Mand. 5. 367, et Manual, p. 7.

C. agilis, var. a, Heer, Faun. Helv. 11. 
Oblong, rather depressed. Head pitchy brown, wide, with a deep fovea on each side between the antennæ; eyes large, globose and black, palpi and antennæ pale testaceous. Thorax ferruginous, subquadrate, rounded in front below the anterior angles, narrowed behind, margins reflexed, base truncate, hinder angles somewhat rotundate, base with a more or less distinct fovea on each side. Elytra fuscous or pitchy, sometimes with a pale oblong patch on each rather before the middle, sometimes wholly testaceous in less mature examples, much wider than the thorax, shoulders rounded, sides rather widest behind the middle, apex as usual truncate, disk rather depressed, obsoletely striated, with a series of impressions between the second and third, and another between the seventh and eighth striæ; body beneath testaceous red, legs pale. Length $2 \frac{3}{4}$ lines.

This species is rather variable in colour, and occasionally in some slight degree in form, the thorax being more quadrate in some examples, and the sides less rounded in front, than in others, which variations have led to the supposition that they are distinct species. I have examined carefully the insects recorded by Mr. Stephens under the names meridionalis and fenestratus, and they appear to be simply varieties of this species, whose claim to distinction rests upon an eccentricity of colour, but upon no constant or very material difference in form or sculpture. Dr. Schaum considers D. fenestratus of Stephens's Collection a variety of testaceus, Erichson, with a yellow dash on the anterior part of the elytra; it is described by Dejean as agilis, var. $a$, and I believe correctly, for the several examples received from abroad of testaceus, Erichson, do not, upon a close examination, present differences of sufficient importance to warrant their separation. Whether, as Dr. Schaum supposes (Stettin Ent. Zeit.), D. fenestratus, Stephens, differs from C. fenestratus, Fab., or whether it be perfectly identical with it, the latter itself is now generally accepted as a variety also of D. agilis.

This species is generally distributed, and is in many parts of the kingdom abundant, under the bark of trees and among the damp herbage of hedge-banks.

4. D. quadrimaculatus : oblongus; capite nigro, thorace rufo, subquadrato, angulis rotundatis; elytris substriatis, fuscis, maculis duabus antennis pedibusque pallidis.

Carabus quadrimaculatus, Linn. F. S. 813.-Fab. S. El. 1.207. Lebia quadrimaculata, Gyll. Ins. Suec. 2. 186.-Dufts. Faun. 2. 250 . 
Dromius quadrimaculatus, Dej. Spec. 1. 239; Icon. 1. 115. pl. 12.-Sturm, D. F. 7. 33.--Steph. Mand. 1.21, et Manual, p. 7. - Erichson, Käfer, 30.-Heer, Faun. Helr. 10.

In form like the preceding, but smaller. Head black, roundish, strigose, having a fovea on each side between the antennæ, the latter with the palpi and mouth pale testaceous. Thorax ferruginous red, rather shorter than in agilis, much wrinkled transversely on each side the dorsal furrow, base with a fovea near each hinder angle, the latter a little rounded, and the margins elevated. Elytra fuscous black, with an oblong testaceous spot before the middle, and a shorter one of the same colour at the apex, and usually entirely covering it, the disk very distinctly striated, the striæ obsoletely punctured, the sixth with a series of deeper impressions; thorax and breast beneath ferruginous; abdomen obscure black; legs testaceous. Length $2 \frac{1}{2}$ lines.

Widely distributed.

5. D. quadrinotatus : oblongus; capite nigro, thorace piceo, subelongato, posticè attenuato, angulis posticis prominulis; elytris fuscis, substriatis, maculis duabus antennis pedibusque pallidis.

Carabus quadrinotatus, Panz. Faun. 73. 5.

Lebia quadrinotata, Dufts. Faun. 2. 253.

Dromius quadrinotatus, Dej. Spec. 1. 238; Icon. 1. 114. pl. 12. -Sturm, D. F. 7. 38. - Steph. Mand. 1.21, et Manual, p. 7. -Erichson, Käfer, 31.-Heer, Faun. Aust. 10.

Oblong, slightly depressed, black. Head large, smooth, flattish in front with a fovea on each side between the antennæ, which together with the palpi and mouth are pale testaceous. Thorax pitchy, slightly elongated, a little rounded below the anterior angles, then obliquely sloped and narrowed to the base, the sides being margined, and the hinder angles elevated and rather prominent, having near each a deep fovea. Elytra oblong, rounded at the shoulders, slightly widest behind the middle, very obsoletely striated, having a large ovate pale testaceous spot at the base and a smaller one before the apex; legs pale testaceous. Length 2 lines.

Generally distributed under bark of trees, \&c.

6. D. quadrisignatus: oblongus; capite nigro, thorace quadrato, rufo; elytris substriatis, fuscis, maculis magnis duabus antennis pedibusque pallidis.

Dej. Spec. 1. 236 ; Icon. 1. 111. pl. 11.-Babington, Ent. 
Trans. 1. 10. 2.-Steph. Mand.5.367, et Manual, p. 7.-Heer, Faun. Helv. 10.

Head obscurely black, smooth, slightly convex, with the forepart, mouth, palpi and antennæ testaceous. Thorax quadrate, anterior angles rounded, sides narrowed towards the posterior angles which are obtuse, the surface entirely ferruginous red, with the centre sometimes pitchy. Elytra with the humeral angles slightly rounded, the sides somewhat straight, faintly striated, fuscous, with two testaceous spots on each, a large denticulated one in front and a smaller one at the apex; abdomen pitchy, legs pale testaceous. Length 2 lines.

This species is nearly allied to the preceding, but may be distinguished by the following characters. The head is shorter and more convex, the forehead not depressed, but with merely a slight impression on each side, not deeply foveated, nor distinctly striated, as in the allied species; the antennæ are shorter and stouter; the thorax is broader and entirely rufous; the elytra are wider at the base, with the shoulders less rounded, and their pattern is more varied, the anterior spots being angular and denticulated instead of ovate, and the abdomen is pitchy.

It appears to be a scarce species, but has been taken in Madingley Wood, and elsewhere near Cambridge; at Colney Hatch and Wimbledon Park; and near Weston-on-the-Green, Oxon.

7. D. sigma: testaceus; capite nigro, thorace subquadrato, elytris substriatis, suturâ fasciâque posticâ dentatâ fuscis.

Carabus sigma, Rossi, Faun. Etr. 1. 226 (1790).

Dromius sigma, Dej. Spec. 1. 235 ; Icon. 1. 110. pl. 11.Erichson, Käfer, 32.-Heer, Faun. Helv. 9.

Carabus fasciatus, Payk. Mon. 97 (1790).-Fab. Ent. S. 1.133 (1792-8).-Fab. S. El. 1. 186.

Dromius bipennifer, Babington, Ent. Trans. 1. 86. 9.-Steph. Manual, p. 7.

Oblong, depressed. Head black, round and flattish, with a small fovea on each side between the eyes; palpi and antennæ testaceous yellow. Thorax red, subquadrate, anterior angles rounded, sides narrowed behind, with their margins elevated, and a slight impression on each side at the base close to the posterior angles, the dorsal furrow very distinct. Elytra testaceous, with a brown transverse toothed fascia behind the middle, leaving a pale spot at the apex, the disk more or less indistinctly punctate-striated; abdomen rufescent and margined with fuscous; legs pale testaceous. Length $1 \frac{1}{2}$ line.

There are several varieties of this insect which present a slight 
difference in the pattern of the elytra, among them one which occurs locally in the Isle of Wight. It has a pale spot on the shoulders, extending not more than half so far downwards as in the insect figured by Dejean, and the transverse band is much broader and darker, leaving merely two minute dots (sometimes united) at the apex. The pattern in these again also varies more or less, as well as in the Cambridgeshire insects.

This species, the $D$. bipennifer of the British Collections, is abundant near Whittlesea Mere and in the Cambridgeshire fens, and is found also near Dorking, Carlisle, and in North Wales.

8. D. fasciatus : subelongatus, testaceus; capite nigro; thorace quadrato ferrugineo; elytris substriatis basi pallidis posticè fuscis, maculá antennis pedibusque pallidis.

Lebia fasciata, Gyll. Ins. Suec. 4. 459.

Dromius fasciatus, Dej. Spec. 1. 238 ; Icon. 1. 113. pl. 12.Steph. Mand. 1.24, et Manual, p. 7.-Erichson, Käfer, 31.Heer, Faun. Helv. 10.

Rather elongate, depressed. Head black, wide, appearing finely coriaceous under a magnifying glass, having a faint stria on each side in front; antennæ and palpi testaceous, apex of the latter pitchy. Thorax rusty brown, with the margins and hinder angles pale testaceous, quadrate, anterior angles rounded, sides slightly narrowed behind and again slightly produced before the posterior angles, which are a little elevated but obtuse, the base with an impressed fovea on each side. Elytra oblong, rusty brown with a pale testaceous patch covering the shoulders and extending nearly half way downwards, not touching the suture, and also a small round or ovate spot of the same livid colour near the tip; in some examples the spots are more or less indistinct or nearly obliterated, in others they run into one another ; body beneath fuscous black; legs pale testaceous. Length $1 \frac{1}{2}$ line.

Widely distributed, but local and found chiefly in sandy situations, in damp ditches and hedge-banks. Abundant at Deal, in Cambridgeshire, Devon, at Berwick-upon-Tweed; "on the sea-coast at Bamborough, Beadnell and Embleton, in June," $J$. Hardy; and in Ireland.

9. D. melanocephalus : testaceus; capite nigro, elytris substriatis, antennis pedibusque pallidis.

Dej. Spec. 1. 234 ; Icon. 1. 109. pl. 11.-Sturm, D. F. 7.44.Steph. Mand. 1. 22, et Manual, p. 7.-Erichson, Käfer, 32.Heer, Faun. Helv. 9.

In form like the preceding, but shorter and very much smaller. 
Head black and shining; palpi and antennæ pale testaceous. Thorax testaceous red, subquadrate, the length rather less than the breadth, a little narrowed at the base, the posterior angles slightly elevated and nearly rectangular. Elytra livid testaceous, and usually transparent so as to show the wings distinctly beneath, a little widest behind, obsoletely striated, especially at the sides; underside of the body dusky ferruginous; legs pale. Length $1 \frac{1}{4}$ line.

Generally distributed.

10. D. glabratus : oblongus, nigro-subaneus; thorace subquadrato, posticè angustato, glabrato ; elytris sublævibus.

Lebia glabrata, Dufts. Faun. 2. 248.

Dromius glabratus, Dej. Spec. 1. 244 ; Icon. 1. 121. pl. 13.Steph. Mand. 1. 25, et Manual, p. 8.-Heer, Faun. Helv. 11. Carabus femoralis, Marsham, Ent. 463.

Dromius femoralis, Steph. Mand. 1. 25, et Manual, p. 8.

D. angustatus, (Curtis) Steph. Manual, p. 8.

D. maurus, Steph. Mand. 1. 176, et Manual, p. 8.

Deep glossy or bronzed black. Head round, smooth and convex. Thorax subquadrate, narrowed behind, the sides and base considerably rounded, with the posterior angles nearly ob. solete, the central line very fine and the disk glabrous. Elytra oblong, depressed, with the humeral angles rather prominent, the disk glabrous, with a few rudiments only of striæ; legs occasionally pitchy. Length $1 \frac{1}{4}$ line.

C. femoralis, Marsham, is an immature representative of this species, from which $D$. angustatus and maurus cannot be separated.

Very common.

11. D. truncatellus : nigro-subaneus; thorace brevi subcordato, posticè rotundato; elytris substriatis; antennis basi tibiisque piceis.

Carabus truncatellus, Linn. S. N. 2.673.-Fab. S. El. 1. 210. Lebia truncatella, Gyll. Ins. Suec. 2. 182. -Dufts. Faun. 2. 247. Dromius truncatellus, Dej. Spec. 1.248 ; Icon. 1. 127. pl. 13.Sturm, D.F. 7. 51.- Steph. Mand. 1. 26, et Manual, p. 8.Erichson, Käfer, 33.-Heer, Faun. Helv. 11.

In form like $D$. foveolus, but rather shorter and smaller, without any brassy tinge and without any fovere on the elytra. Head and eyes smaller.: Thorax shorter, subcordate, with the sides regularly rounded behind, posterior angles very obtuse. Elytra shorter than in foveolus and slightly wider, the humeral angles rounded, apex wide and truncate, disk very obsoletely striated; 
body beneath black; antennæ and legs black or slightly pitchy. Length $1 \frac{1}{3}$ line.

This insect is larger than the preceding and much broader, but not quite so large as the next species; it cannot be confounded with either, it is more pitchy black, and has the sides of the elytra very distinctly rounded, and is both shorter and wider than either of the allied species : from foveolus (with which it associates as well as with glabratus) it may instantly be distinguished also by the absence of the small punctures, and the brassy brown colour so conspicuous in that insect.

This species has, together with the two following, been erected into a separate genus (Metabletus) by Dr. Schmidt.

It is far from uncommon, though certainly local. I have taken it at Redhill, Surrey, on the common near the Railway Station; and in Pegwell Bay near Ramsgate, on a grassy bank on the edge of the shore, early in the spring. "Found in sandy and gravelly situations beneath stones near London," Mr. Stephens. It is also included among the Irish species by Mr. Haliday.

12. D. foveolus : obscurè aneus; elytris substriatis, punctis duobus impressis.

Lebia foveola, Gyll. Ins. Suec. 2. 183.

Dromius foveolus, Steph. Mand. 1. 26, et Manual, p. 8.Erichson, Käfer, 33.

Lebia punctatella, Dufts. Faun. 2. 248.

Dromius punctatellus, Dej. Spec. 1.247; Icon. 1. 126. pl. 13.Sturm, D. F. 7. 52.-Heer, Faun. Helv. 11.

Above obscure brassy brown. Head smooth, with an obsolete fovea on each side between the antennæ which are pitchy black, eyes large. Thorax short, broad, narrowed behind as in the preceding species, and the posterior angles obtuse and elevated, but with the base sloped upwards to meet them, the dorsal line very distinct, but the basal foveæ almost obsolete. Elytra rounded at the shoulders, and rather so on the sides, moderately convex, obsoletely punctate-striated, with two deep impressions on the third stria; legs black, slightly pitchy. Length $1 \frac{1}{2}$ line.

This insect occurs in profusion almost everywhere in sandy and gravelly places. "Portmarnock sands" in Ireland, $A . H$. Haliday, Esq.

+ 13. D. obscuroguttatus : piceo-subæneus ; elytris substriatis, maculis duabus alterấ humerali alterâ apicali antennarum basi tibiisque rufescentibus.

Lebia obscuro-guttata, Dufts. Faun. 2. 249. 
Dromius obscuroguttatus, Erichson, Käfer, 32 .

D. spilotus, Dej. Spec. 1. 246 ; Icon. 1. 124. pl. 13.-Sturm,

D. F. 7. 47.-Curtis, Ent. pl. 231.-Steph. Manual, p. 7.

D. impunctatus, Steph. Mand. 1. 23.

In form like the two preceding species, but pitchy black with a faint brassy tinge. Head convex, smooth, with a very obsolete stria on each side in front, and the whole surface, when examined under a magnifying glass, finely coriaceous. Thorax as in foveolus, but rather narrower (Pl. I. f. 1). Elytra broad with the shoulders rounded and slightly prominent, apex obliquely truncate, disk very obsoletely striated, with a series of deep inpressions on the exterior margins, pitchy or fuscous black, with a pale more or less distinct spot on the shoulders and another (often obliterated) near the apex; thighs pitchy, tibiæ and tarsi paler. Length $1 \frac{1}{2}$ line.

This species is rather scarce. The localities given by $\mathrm{Mr}$. Stephens are Norfolk, Berkshire, and near London. I once met with it in profusion near Sandown, Isle of Wight (April 1846), and have found it also at Gravesend and in Hurst Wood, near Tunbridge Wells.

14. D. quadrillum : nigro-subøneus; thorace lateribus rotundato posticè fortiter coarctato, angulis posticis acutis; elytris striatis, interstitiis punctatis, maculis duabus pallidis.

Lebia quadrillum, Dufts. Faun. 2. 246.

Dromius quadrillum, Dej. Spec. 1. 249 ; Icon. 1. 127. pl. 13. -Sturm, D. F. 7.45.-Steph. Mand. 1.23, et Manual, p. 8. -Heer, Faun. Helv. 12.

Lionychus quadrillum, Redt. Faun. Aust. 76.

Var. $\beta$. elytris singulis unimaculatis.

Dromius bipunctatus, Heer, Faun. Helv. 12.

Above bronzed black, rather larger and wider than the preceding species. Head round, wide, obliquely impressed on each side between the antennæ, two joints at the base of the latter red. Thorax broad in front and short, rounded at the sides below the anterior angles, but suddenly and considerably contracted behind, the base also being rounded as in the preceding species, and sloped upwards to meet the posterior angles which are very minute, acute and prominent (Pl.I. f. 2), disk with a fine dorsal line and a transverse impression in front thereof, and the base striated longitudinally. Elytra broad, short, humeral angles rounded and rather elevated, sides dilated behind, the surface finely but evidently striated, and the interstices minutely punctured, having two yellowish white spots on each elytron, one at the basal angle and another a little behind the middle, the 
latter of which is sometimes wanting; body beneath and the legs black. Length $1 \frac{1}{2}$ line.

To receive this species a new genus (Lionychus) has been created by Dr. Wissmann (Stettin Ent. Zeit. 7. 25). The Stettin Catalogue (1852) records this insect as Carabus 4-pustulatus of Fabricius, but as that author's description and references are unsatisfactory, I have retained the generally received name. The species is apparently scarce. Mr. Stephens informs us that it has been taken near London and at Southend. Mr. Wollaston captured a pair near Bridport, Dorset, and a fine series at Slapton Ley, Devon, in May 1852 : these belong to the variety with the humeral spots alone visible. During the month of May in the year 1853, my friends Mr. Wollaston and the Rev. H. Clark, as well as myself, found it in plenty among the fine shingle at the base of the low cliffs eastward of Southend. Among the individuals captured by us, every variety is included.

\section{Genus 5. IFBIA, Latreille.}

Mentum dente medio nullo. Ligula apice rotundata; paraglossis coriaceis, ei subaqualibus, apice singulatim rotundatis. Palpi articulo ultimo subovato, apice truncato. Tarsi articulo quarto emarginato; unguiculis pectinatis.

When Bonelli separated the genera Demetrias and Dromius from Lebia proper, he also divided the latter into Lamprias and Lebia. He took $L$. cyanocephala as the type to represent the characters of the former, which he stated to consist in the penultimate joint of the tarsi being simple, the antennæ linear, and the last joint of the palpi truncate;-and as the type of the latter he took L.crux-minor, having the penultimate joint of the tarsi bifid, the antennæ more slender at the base, and the last joint of the palpi less truncate. Upon a close examination, however, of the different species of Lebia, it did not appear that these characters held good; for even in $L$. cyanocephala, the type of the genus Lamprias, the penultimate joint of the tarsi is not simple, but bifid; neither is it simple in any of the others, though in some it is difficult to decide whether it is bifid or bilobed; and as the two remaining characters assigned by Bonelli appeared altogether too vague to warrant the creation of a new genus, M. Dejean once more reunited the Lamprias and Lebia of Bonelli under the original name Lebia*, an arrangement which has now been adopted generally by the continental entomologists.

* Dejean, Iconographie, vol. i.p. 132. 
1. L. crux minor: nigra; thorace antennarum basi pedibusque rufis, elytris testaceis cruce nigrâ.

Carabus crux minor, Linn. S. N. 2. 673.

Lebia crux minor, Gyll. Ins. Suec. 2. 181.-Sturm, D. F. 7. 24. -Dej. Spec. 1. 261 ; Icon. 1. 139. pl. 15.-Steph. Mand. 1. 27, et Manual, p. 8.-Heer, Faun. Helv. 13.

Head black, coarsely punctured; palpi black; antennæ fuscous, with three joints at the base red. Thorax ferruginous red, finely punctured, with a slight central longitudinal line and wrinkled transversely; scutellum black. Elytra broad, shoulders rounded and prominent, sides widest behind the middle, finely punctate-striated, with two minute dots on the third stria from the suture, testaceous red, with a triangular black patch surrounding the scutellum, the black colour passing all down the suture to the apex, and being crossed behind the middle by a broad transverse waved band of the same colour dilated at the sides and next the suture, leaving a round immaculate spot at the apex : underside of the body black, except the thorax, which, together with the legs, is red. Length 3 lines.

The instances recorded of the capture of this rare species in Britain are very few. Coombe Wood, Windsor, Plumstead Common, Bristol, Lymington, and Netley have produced each a solitary example. More recently, Mr. Stephens secured one in Unsted Wood, near Godalming (Aug. 27, 1842), and Mr. Wollaston brushed one into his net from a damp meadow at Treneglos, in Cornwall, on 11th September, 1844. Two specimens were taken in a sandy lane near Tunbridge Wells by Major Stanhope Taylor, one of which he kindly presented to me. "Beaten off a sallow near Lugs, south end of Loch Lomond, by Mr. R. Logan." Murray's Catalogue.

2. L. turcica : nigra, thorace rufo; elytris striatis, nigris, maculâ magnâ humerali pedibusque testaceis.

Carabus turcicus, Fab. S. El. 1. 203.

Lebia turcica, Dej. Spec. 1. 263 ; Icon. 1. 142.pl. 15.-Curtis, Ent. pl. 87.-Steph. Mand. 1. 27, et Manual, p. 8.-Heer, Faun. Helv. 13.

Rather smaller than crux minor. Head black, punctured behind, and wrinkled in front between the eyes ; mouth, palpi and antennæ red. Thorax red, with a deep central longitudinal line, bordered by numerous transverse wrinkles; scutellum red. Elytra black, with a large testaceous red patch on the shoulders, and a very slender margin of the same colour extending to the apex, deeply striated, the striæ sparingly punctured, 
the third from the suture with two impressed dots; breast ferruginous; abdomen black, with a pale spot in the centre; legs pale testaceous. Length $2 \frac{1}{2}$ lines.

The claim of this rare species to be inserted in the British fauna rests upon four specimens, reported to have been captured in Oakhampton Park, and presented to the British Museum by Dr. Leach. Mr. Stephens, however, calls our attention to the fact that Fabricius quoted this insect as British from a specimen in the collection of Dr. Hunter.

3. I. hæmorrhoidalis : rufa, elytris nigris, apice rufis.

Carabus hamorrhoidalis, Fab. S. El. 1. 203.-Panz. Faun. 75. Lebia hamorrhoidalis, Dej. Spec. 1. 266 ; Icon. 1. 145. pl. 15. -Steph.Mand. 1.28, et Manual, p.8.-Heer, Faun. Helv. 13.

This species is about two-thirds the stature of $L$. crux minor and is entirely red, with the exception of the elytra, which are shining blue-black, with their apex red. Head and thorax finely punctured; the latter short, much dilated and rounded at the sides, the central line bordered by numerous fine transverse wrinkles. Elytra with the shoulders rounded and prominent, sides dilated behind the middle, apex obliquely truncate, faintly striate-punctate, with two impressed dots on the third stria from the suture. Length 2 lines.

The claim of this elegant little species to be admitted into our indigenous fauna rests upon a single example, which Mr. Stephens reports to have been captured near Netley, Shropshire, on broom, by the Rev. F. W. Hope.

\section{(Lamprias, Bonelli.)}

4. I. cyanocephala : cyanea vel viridis, thorace pedibusque rufis, femoribus apice cæruleo-nigris, elytris punctato-striatis, interstitiis punctatis.

Carabus cyanocephalus, Linn. F. S. 794.-Fab. S. El. 1. 200. Lebia cyanocephala, Gyll. Ins. Suec. 2. 179.-Dej. Spec. 1. 256; Icon. 1. 134. pl. 14.-Sturm, D. F. 7.21.-Erichson, Käfer, 34.-Heer, Faun. Helv. 12.

Lamprias cyanocephalus, Steph. Mand. 1. 29, et Manual, p. 8. L. nigritarsis, Steph. Mand. 1. 29, et Manual, p. 9.

Bright green or cyaneous, very brilliant and shining, with the thorax ferruginous red. Head thickly punctured, and with an obsolete fovea on each side between the eyes; mouth pitchy; palpi and antennæ blackish, with the basal joint of the latter 
red. Thorax transverse, short, widest in front, sides rounded, slightly narrowed behind, posterior angles acute, disk rather convex, thickly punctured, with a distinct longitudinal dorsal furrow, and a deeply impressed transverse line at the base, and an obsolete fovea on each side likewise thickly punctured; scutellum blue-black. Elytra narrowed and rounded at the shoulders, dilated behind, apex obliquely truncate, finely punctatestriated, interstices more or less punctured; thorax beneath red, breast and abdomen bluish green, legs red, with the tip of the thighs bluish green, tarsi fuscous black. Length $2 \frac{1}{2}-3 \frac{1}{4}$ lines.

This species is variable in size, though usually somewhat larger than the next: it differs chiefly in having the tips of the femora, the breast and scutellum bluish black instead of red. It is local, but has been found at Darenth Wood, Ripley, Windsor, \&c. It is the L. nigritarsis of Leach.

5. I. chlorocephala: cyanea vel viridis; thorace pedibusque rufis ; elytris punctato-striatis, interstitiis subtiliter punctatis.

Carabus chlorocephalus, Ent. Heft 2. 117.

Lebia chlorocephala, Gyll. Ins. Suec. 2. 180.-Dej. Spec. 1. 257 ; Icon. 1. 136. pl. 14.-Sturm, D. F. 7. 22.-Erichson, Käfer, 34.-Heer, Faun. Helv. 12.

Lamprias chlorocephalus, Steph. Mand. 1. 30, et Manual, p. 9. L. rufipes, Steph. Mand. 1. 30, et Manual, p. 9.

Brilliant shining green or cyaneous, with the thorax red. Head thickly punctured; palpi black; antennæ fuscous black, with the first, second, and basal half of the third joints red. Thorax rather longer, and more narrowed behind than in the preceding species, posterior angles prominent, convex, thickly punctured, with a slight dorsal line, and a transverse impression at the base; scutellum red. Elytra more finely punctured than in the preceding species; thorax and breast beneath testaceous red; abdomen bluish green; legs red, with the tarsi fuscous black. Length $2 \frac{1}{2}-3$ lines.

Abundant in many parts of the kingdom on the common broom, and at the roots of the gorse. L. rufipes, Steph., is the same species.

\section{Tenus 6. BRACHINUS, Weber.}

Mentùm (plerumque) dente medio nullo. Ligula medio angustè cornea, lateribus membranacea; paraglossis apice subacuminatis, eam parìm superantibus. Palpi articulo ultimo cylin- 
drico, aut subovato, apice truncato. Mandibulæ firma, acuta. Labrum brevissimum, angulis anticis rotundatis, apice subsinuatum. Tarsi articulo quarto integro; unguiculis simplicibus.

1. B. crepitans : rufo-ferrugineus; elytris substriatis, nigrosubcyaneis ; antennarum articulo tertio quartoque abdomineque infuscatis.

Carabus crepitans, Linn. S. N. 2. 671.

Brachinus crepitans, Fab. S. El. 1.219.-Gyll. Ins. Suec. 2.176. -Dej.Spec. 1. 318; Icon. 1. 161.pl. 17.-Sturm, D. F. 7.79. -Steph. Mand. 1. 34, et Manual, p. 9.-Frichson, Käfer, 26. -Heer, Faun. Helv. 14.

B. immaculicornis, Steph. Mand. 1. 177, et Manual, p. 9.

B. explodens, Steph. Mand. 1. 35, et Manual, p. 9.

B. glabratus, Steph. Mand. 1. 36, et Manual, p. 9.

Ferruginous red, elytra black, blue-black, steel-blue or greenish, pubescent. Head oblong, punctured behind, having an oblong rugose fovea on each side in front; eyes large and black; basal joint of antennæ bright red, second, third and fourth joints dusky, the rest dull pale red. Thorax oblongcordate, narrow, acutely margined, posterior angles slightly prominent, disk rugosely punctate, with a fine central stria, and a faint transverse line at the base; scutellum pitchy red. Elytra oblong-ovate, broad, shoulders rounded, sides dilated behind the middle, apex truncate, very indistinctly striated, interstices finely punctured; head and thorax beneath red; breast and abdomen pitchy, finely punctured, and clothed with golden pile; legs rusty red and pubescent. Length 3-4 lines.

This little Bombardier is very abundant in the south of England; it occurs in profusion in the Undercliff, Isle of Wight; and both in size and colour varies considerably, in the latter respect from dull black to steel-blue. The insects recorded by Mr. Stephens under the names immaculicornis, explodens and glabratus must be referred to this species. The insect is found also in the counties of Wexford and Louth in Ireland.

2. B. sclopeta : ruber; elytris sublavibus, cyaneis, suturâ abbreviatá ferrugineá.

Carabus sclopeta, Fab. S. El. 1. 220.

Brachinus sclopeta, Clairv. Ent. Helv. 2.41.-Dej. Spec. 1.322; Icon. 1. 167. pl. 18.-Sturm, D. F. 7. 82.-Steph. Mand. 1. 36, et Manual, p. 9.-Curtis, Ent. pl. 554.-Heer, Faun. Helv. 15.

Rusty red, elytra cyaneous and pubescent, with the suture 
ferruginous red from the base to about two-thirds its length. Head faintly punctured behind, with an oblong rugose impression on each side in front. Thorax cordate, finely rugose-punctate. Elytra shorter and wider in proportion than in crepitans, shoulders broader and more prominent, sides very little wider behind the middle, obsoletely striated, interstices faintly punctured; body beneath entirely rusty red. Length 2-3 lines.

This species is usually smaller than the smallest examples of crepitans, and in form more delicate, and may at once be recognized by an abbreviated red dash at the base of the suture. Its claim to be admitted into our British fauna rests apparently on very few examples; the first recorded by Mr. Curtis as having been captured by Dr. Leach in Devonshire; a second reputed to have been taken by the Rev. F. W. Hope at Southend; and a third, in Mr. Stephens's collection, supposed to have been found near Hastings. There are others in the collection of the late Mr. Vigors, and in that of the Rev. A. Matthews (which last were obtained from Mr. Vigors), said to have been captured in Norfolk.

\section{Genus 7. TARUS, Clairville.}

(Crmindis, Latreille.)

Mentum dente medio integro. Ligula obtusa; paraglossis membranaceis, ei aqualibus, apice rotundatis. Palpi maxillares externi filiformes, articulo ultimo cylindrico, labiales articulo ultimo securiformi. Mandibulæ breves externè profundè sulcate. Labrum quadratum, apice truncatum. Tarsi articulis integris; unguiculis serratis.

1. T. humeralis : niger, parcè punctatus ; elytris striatis, margine laterali macula humerali ore antennis pedibusque ferrugineis.

Carabus humeralis, Fab. S. El. 1. 181.

Lebia humeralis, Dufts. Faun. 2. 240.

Cymindis humeralis, Gyll. Ins. Suec. 2. 172.-Dej. Spec. 1. 204; Icon. 1. 80. pl. 8.-Sturm, D. F. 7. 8.-Erichson, Käfer, 693. -Heer, Faun. Helv. 7.

Tarus humeralis, Steph. Mand. 1. 33. pl. 2, et Manual, p. 9.

Black and glabrous. Head large, thickly punctured; mouth, palpi and antennæ red. Thorax cordate, longer than in the next species, sides less dilated and rounded in front (Pl. I. f. 3), much narrowed behind, broadly margined, slightly rounded at the base, with the posterior angles minute but slightly promi- 
nent, disk finely and sparingly punctured, sides more coarsely punctured, the base with a deep fovea near each hinder angle; scutellum pitchy red, punctured. Elytra oblong-ovate, rounded at the shoulders, rather widest behind the middle, deeply striated, the striæ obsoletely punctured, interstices also finely punctured, the outer margins testaceous almost to the extremity, and a large oblong patch of the same colour on the shoulders connected with the marginal streak; body beneath pitchy red, legs testaceous red. Length 4-5 lines.

This insect is larger and has a more elongate form than the next species, from which it is distinguishable in the structure and colour of the thorax, which is longer, narrower, and entirely black. It is of very rare occurrence in Britain, but according to Stephens has been taken at Swansea, and near Cuckfield, Sussex. There is a single example only in the Stephensian collection.

2. T. axillaris : fusco-niger, subpubescens, subtiliter punctatus, thorace rufo, elytris punctato-striatis, margine laterali lineolâque humerali ore antennis pedibusque ferrugineis.

Carabus axillaris, Fab. Ent. S. 1. 132 (1792-8).

Tarus axillaris, Steph. Mand. 5. 388, et Manual, p. 9.

Lebia homagrica, Dufts. Faun. 2. 240.

Cymindis homagrica, Sturm, D. F. 7. 10.-Dej. Spec. 1. 208 ; Icon. 1. 83. pl. 9.-Heer, Faun. Helv. 7.-Redt. Faun. Aust. 74.

Tarus homagricus, Steph. Mand. 5. 369, et Manual, p. 10.

T. angularis, Steph. Mand. 1. 31, et Manual, p. 10.

T. lavigatus, Steph. Mand. 1. 32.

T. macularis, Steph. Mand. 5. 368.

T. coadnutus, Steph. Mand. 5. 369, et Manual, p. 9.

Fuscous black, slightly pubescent. Head large, black, finely punctured behind, but with the sides and an oblong impression on each side in front more coarsely punctured; palpi and antennæ red. Thorax cordate, short, very wide in front (P]. I.f. 4), sides rounded below the anterior angles, much rounded behind so as to leave the posterior angles very minute, ferruginous red, thickly punctured, more coarsely so on the sides, having a slender dorsal line and a round fovea on each side at the base. Elytra wide and rather short, shoulders very prominent, dilated behind the middle, apex obliquely truncate, deeply striated, stria finely punctured, interstices thickly punctured, the punctures in some examples finer than in others, fuscous black, with an oblong patch on the shoulders, and the entire margin testaceous, and sometimes with a more or less pitchy-red spot near the extremity of the wing-cases; thorax and breast beneath 
reddish, punctured; abdomen black, smooth and shining; legs ferruginous. Length $3 \frac{1}{2}-4$ lines.

The insects recorded by Mr. Stephens under the names T. axillaris, coadnutus, lavigatus, homagricus, angularis and macularis, if they have no other representatives but those contained in the Stephensian cabinet, must all be assigned to this species.

Found in chalky districts, but local. Dorking, at the foot of Box hill ; Freshwater, Isle of Wight; at the back of the Castle in the Isle of Portland; New Forest, \&c., late in August and September, and occasionally in April and May.

3. T. vaporariorum: niger, subpubescens profundè punctatus ; elytris punctato-striatis basi ferrugineis, ore antennis pedibusque testaceis.

Carabus vaporariorum, Linn. S. N. 2. 671.

Cymindis basalis, Gyll. Ins. Suec. 2. 175.-Sturm, D. F. 7.15. -Redt. Faun. Aust. 74.

Tarus basalis, Curtis, Ent. pl. 235. - Steph. Mand. 1. 177, et Manual, p. 10.

Cymindis punctata, Dej. Spec. 1. 214 ; Icon. 1. 92. pl. 10.Heer, Faun. Helv. 8.

Head and thorax black, coarsely punctured, palpi and antennæ ferruginous. Thorax heart-shaped, rather narrow, sides rounded in front, contracted behind, posterior angles acute and prominent, each with a very obsolete fovea. Elytra oblong-ovate, slightly pubescent, punctate-striated, pitchy black or pitchy chestnut, with a more or less distinct red dash on the shoulders and covering the entire base; body beneath pitchy black, deeply punctured; legs red. Length $4-4 \frac{1}{2}$ lines.

This insect cannot be confounded with the preceding. The form is narrower and more elongate; the punctuation, especially on the head and thorax, is very coarse; the thorax is considerably smaller, more contracted, and has the posterior angles distinctly acute and prominent; the elytra also are narrower, the shoulders rounded and narrowed, not at all prominent like those of the preceding species, and the entire base is red, but the lateral margins concolorous with the rest of the wing-cases, and the underside is thickly punctured and pubescent.

In the Linnæan collection we find this species labelled as the true Carabus vaporariorum, Linn. I have accordingly restored the name. It is found in mountainous districts in the north of England, Scotland, and North Wales. Midgley Moor, near Halifax: "on the moors near Twizel," Mr. Selby. I have taken it abundantly on Griben Oernant, near Llangollen, about the middle of August. 


\section{Genus 8. POLYSTICFUS, Bonelli.}

Mentum breve, dente medio abbreviato, dilatato, emarginato. Ligula membranacea apice obtusa, paraglossis membranaceis, ei adnatis. Palpi articulo ultimo paulò crassiore, subsecuriformi. Mandibulæ breviuscula vix prominula. Labrum quadratum, apice truncatum.

1. P. fasciolatus : brunneus, pubescens, valdè punctatus, elytrorum vittá abbreviatá pectore abdomine pedibusque ferrugineis.

Carabus fasciolatus, Oliv. Ent. 3. 33.

Galerita fasciolata, Fab. S. El. 1. 216.

Polystichus fasciolatus, Sturm, D. F. 7.69.-Dej. Spec. 1. 194; Icon. 1. 72. pl.7.-Steph. Mand. 1.13.-Curtis, Ent. pl. 223. - Heer, Faun. Helv. 6.

P. vittatus, Steph. Manual, p. 10.

Pitchy red, pubescent. Head much produced in front, and coarsely punctured; palpi and antennæ rusty red. Thorax elongate, heart-shaped, sides rounded in front, much narrowed behind, posterior angles acute, coarsely punctured, with an oblong fovea on each side at the base. Elytra very pubescent, with a red streak extending from the base to about the middle of each elytron, shoulders rounded, sides parallel, apex truncate, deeply striated, the striæ and interstices thickly and finely punctured: head and thorax beneath pitchy red, coarsely punctured; abdomen pale, very minutely punctured; legs rusty red. Length 5 lines.

Very rare. "Once in profusion under a heap of stones, near Southwold, Suffolk, in April 1828." C. J. Hewitson, Esq. I captured a single specimen near Sandown, in the Isle of Wight, in April 1846.

\section{Subfam. 2. Scaritides, Westwood.}

\section{Genus 9. CLIVINA, Latreille.}

Mentum dente medio acuto, lobis lateralibus aquali. Ligula cornea, elongata, acuminata : paraglossis membranaccis, angustis, linearibus, ligula aqualibus. Palpi articulo ultimo acuminato. Mandibulæ mediocres, subdentata. Labrum breve, truncatum. Tibiæ anticæ extus dentata, intermediæ extùs ante apicem spinâ armata.

1. C. fossor : nigro-picea, thorace subquadrato, elytris elongatis, subparallelis, striato-punctatis, punctis quatuor impressis; antennis pedibusque rufis. 
Tenebrio fossor, Linn. F. S. 817 ; S. N. 2.675.

Scarites fossor, Ill. Käfer, 3.-Dufts. Faun. 2. 5.

Clivina fossor, Gyll. Ins. Suec. 2. 169.-Steph. Mand. 1. 39, et Manual,p. 11.- Erichson, Käfer, 35.- Heer, Faun. Helv. 16. Scarites arenarius, Fab. S. El. 1. 125.-Sturm, D. F. 2. 128. Clivina arenaria, Dej. Spec. 1. 413.-Icon. 1.215. pl. 23.

This species is pitchy black, with the margins of the elytra and sometimes the suture pitchy red. Head with a deep rugged fovea on each side and a small impression on the crown, palpi and antennæ ferruginous. Thorax nearly quadrate, broadest behind at the posterior angles, disk more or less transversely strigose, the dorsal furrow met in front by a transverse stria which encloses a narrow space. Elytra elongate, sides almost parallel, narrowed towards the apex, deeply striated, the striæ punctured, the third with four remote impressions, and the margins with numerous large punctures; legs ferruginous red. Length 3 lines.

Common in marshy places, on river banks, \&c.

2. C. collaris : rufo-brunnea, thorace castaneo, quadrato, elytris elongatis, subparallelis, striato-punctatis, punctis quatuor impressis.

Carabus collaris, Herbst, Archiv, 5. 141.

Clivina collaris, Steph. Mand. 1.40, et Manual, p. 11.-Curtis, Ent. pl. 175.-Heer, Faun. Helv. 16.-Putz. Mon. 76. 16.

Cl. fossor, var. $b$, Gyll. Ins. Suec. 2. 169.

Cl. arenaria, var. b, Dej. Spec. 1. 413 ; Icon. 1. 215. pl. 23.

Smaller, narrower, and more elongate in proportion than the preceding; the thorax chestnut-brown, the rest of the insect ferruginous. Head shorter and rounder than in fossor. Thorax more quadrate, less dilated at the posterior angles, and the disk smoother. Elytra narrower and more elongate in appearance, rather widest behind the middle, less narrowed towards the apex, less deeply striated, but the four impressions on the third stria more distinct. If its distinctive characters are slight, they are at any rate constant, and its colour is unvariable; the size also is uniformly less than that of the preceding species.

Local. "Beneath stones by the side of the Tyne and Derwent in May and June," Messrs. Hardy and Bold. "Common in Battersea fields," Mr. Stephens. It is found also in Scotland.

\section{Genus 10. DYSCHIRIUS, Panzer.}

Mentum dente medio minimo. Ligula cornea, elongata, apice obtusa; paraglossis coriaceis, abbreviatis. Palpi articulo 
ultimo acuminato. Mandibulæ mediocres, mutica. Tibiæ anticæ extùs bidenticulata, apice producta, intermediæ simplices.

1. D. inermis : nigro-carulescens vel aneo-piceus, nitidus, ore antennisque ferrugineis, elytris oblongo-ovatis, striatopunctatis, punctis tribus impressis, tibiis anticis extìs inermibus.

Curtis, Ent. pl. 354.-Steph. Mand. 5. 369, et Manual, p. 11. -Putz. Mon. 53.

Dyschirius arenosus, Putz. Mon. 48.

D. digitatus, Steph. Mand. 1. 42, et Manual, p. 12.

D. fulvipes, Steph. Mand. 5. 370, et Manual, p. 12.

Bluish black or pitchy æneous, shining; palpi and antennæ at the base ferruginous, the latter dusky towards the apex. Thorax subrotundate and rather globose in front, but narrowed behind, the dorsal furrow deeply impressed, and met in front by a curved transverse channel, the base with a transverse row of punctures. Elytra oblong-ovate, slightly rounded at the sides (Pl. I. f. 9), strongly striated, the strix finely punctured, the third from the suture with three deeper impressions; legs pitchy red, femora darker, anterior tibiæ terminated by two strong spines, the outer one largest and incurved, but without any appearance of the usual denticulations on the tibia externally. Length $2 \frac{1}{4}$ lines.

This species is described in Putzeys' Monographie as D. inermis, Curt.; it is also identical with $D$. arenosus, Putz., of the same work, but not, as that author was led to believe, with arenosus, Steph. The latter insect must be assigned to thoracicus. D. digitatus and fulvipes belong to the present species. Clivina fulvipes, Dej., is unique in the Dejeanian collection. The localities given for this insect are the coasts of Norfolk, Suffolk and Essex.

2. D. nitidus: aneus, nitidus; thorace subrotundato, elytris elongato-ovatis, punctato-striatis, stria marginali ad humerum abbreviatâ, tibiis anticis extùs obtusè bidenticulatis.

Clivina nitida, Dej. Spec. 1. 421 ; Icon. 1. 218. pl. 123.Ahrens, Arehiv, no. 1.

Dyschirius nitidus, Steph. Mand. 1. 40, et Manual, p. 11.Erichson, Käfer, 37.-Heer, Faun. Helv. 17.-Putz. Mon. 49.

Shining brassy. Head with a deep rugose impression on each side between the eyes united in front by a transverse elevated line, running parallel to which are some minute striæ; mouth, mandibles, palpi and basal joint of the antennæ rusty red, apex of the palpi and of the antennæ pitchy. Thorax wide, rather 
narrowed below the anterior angles; thence evidently dilated about the middle and somewhat rounded, but again narrowed behind; disk very convex, with a deep central line bordered by numerous wrinkles and met in front by a transverse oblique stria, which also is wrinkled or striated below. Elytra wider than the thorax, elongate-ovate, having the shoulders rather elevated, very convex, strongly striated, especially at the base and next the suture, the strix distinctly punctured except at the extremity, the marginal stria abbreviated at the shoulder, the first and second next the suture carried almost to the apex, the third and fourth unite before the apex, the fifth and sixth also unite, the seventh and eighth are carried round the margin to the extremity of the suture, where they unite and form a strongly impressed loop (Pl. I. f. 10): the underside of the body is brownish black, the legs pitchy red, thighs somewhat brassy, anterior tibiæ stout and furnished with two strong spines at the extremity of equal length, and a smaller one near the notch, being armed likewise externally with two obtuse teeth. Length $2 \frac{1}{4}$ lines.

This species, the largest of our indigenous Dyschirii, is not very common. Mr. Stephens gives as its localities the shores of the Thames and Humber, but I suspect that examples of salinus, a species not uncommon in those localities, have been mistaken for it. It is found on the Norfolk and Lincolnshire coasts, near Liverpool, \&c.

3. D. politus : aneus, nitidus; thorace oblongo-ovato, elytris elongatis, subparallelis, punctato-striatis, stria marginali ad humerum abbreviatâ; tibiis anticis extùs obsoletè bidenticulatis.

Clivina polita, Dej. Spec. 1. 422 ; Icon. 1. 220. pl. 23.

Dyschirius politus, Steph. Mand. 1.41, et Manual, p.11.-Erichson, Käfer, 38.-Redt. Faun. Aust. 79.-Putz. Mon. 46.50.

Clivina elongata, Ahrens, Archiv, no. 8.

C. metallica, Ahrens, Archiv, no. 5.

Dysćhirius cylindricus, Steph. Manual, p. 12.

Elongate, subparallel, rather narrowed towards the extremity, brassy and shining; mouth, mandibles, base of the palpi and of the antennæ rusty red. Thorax oblong-ovate, with the sides more rounded in some examples than in others, and usually more dilated and straight in the $q$ than in the $\delta$. Elytra broad and somewhat elevated at the shoulders, sides not quite parallel but gradually decreasing in width (Pl. I. f. 11), punctate-striated, the striæ most impressed at the base and next the suture and continued to the extremity, except the third and 
fourth and the fifth and sixth which unite and terminate before it, but they are all much finer as they approach the apex, the punctuation on the striæ likewise disappears before the apex, and the third interstice has three deeper impressions; the anterior tibiæ are furnished with two long spines at their tip and a shorter one near the notch, and armed externally with two obsolete denticulations (Pl. I. f. 13), which in some examples appear like two faint protuberances, but in others are rather more distinct; femora pitchy, tibiæ and tarsi reddish. Length 2 lines.

This species is local, but has been taken rather plentifully at Lowestoff (Zool. p. 1671) and elsewhere, on the Suffolk, Norfolk and Lincolnshire coasts; and near Bridlington, Yorkshire. $D$. cylindricus, Steph., belongs to this species : the true Clivina cylindrica, Dej., has not, as far as I am aware, been found in Britain.

4. D. salinus: aneus, nitidus; thorace brevi subrotundato; elytris subparallelis, striatis, striis profundè punctatis, punctis è medio evanescentibus; pedibus rufo-piceis, tibiis anticis extùs fortitèr bidenticulatis.

Schaum, Germ. Zeitsch. 4. 180.-Putz. Mon. 48. 29.-Redt. Faun. Aust. 79.

Dyschirius rufipes, Steph. Mand. 5. 369.

D. punctatus, Steph. Mand. 5. 370, et Manual, p. 12.

Shining brassy, bluish or greenish brass. Head with two oblong depressions enclosing a central longitudinal ridge between them, which latter is crossed in front by several transverse lines; base of the palpi and of the antennæ red, the rest pitchy. Thorax short and a little globose, the sides being more or less dilated in the middle and regularly rounded, the central line distinctly marked and met in front by a transverse impression, which is bordered on both sides by numerous fine longitudinal striæ. Elytra oblong, sides somewhat parallel or very slightly rounded, apex not attenuated, distinctly striated, striæ coarsely and deeply punctured (Pl. I. f. 12) till behind the middle, where the punctuation becomes indistinct and the striæ are continued to the extremity very finely, the marginal punctured stria is carried over the shoulder, and the third interstice has three larger impressions; legs pitchy red; anterior tibiæ armed externally with two teeth, the one nearest the apex being stout, acute and straight (Pl. I. f. 14). Length $1 \frac{3}{4}$ line.

This species is very distinct from and smaller than the preceding; the thorax is shorter and more oval; the elytra are more parallel and not narrowed at the extremity, and the punctuation is extremely distinct; the exterior denticulations of the anterior tibix larger and more acute. 
It is found in salt marshes and on the banks of tidal rivers : shores of the Thames below Gravesend; Southend; Whitstable and Herne Bay; Lymington Salterns; near Sandown Castle, Deal; shores of the Humber, \&c. ; also on "Portrain sands and Holywood shore in Ireland," A. H. Haliday.

5. D. obscurus : obscure aneus vel nigro-virescens, thorace subgloboso, elytris ovatis, profundè striatis, striis impunctatis, tibiis anticis extùs acutè bidenticulatis.

Clivina obscura, Gyll. Ins. Suec. 4. 456.-Putz. Mon. 16. 8.

This species is smaller and narrower than salinus, and may be recognized by its elongate and cylindric form, and more especially by the deeply impressed stria on the elytra, entirely smooth and impunctate; the anterior tibiæ are armed externally with two distinct teeth, of which the one at the extremity is as large as the corresponding one in salinus; it is black beneath and obscure brassy or greenish black above, with the antennæ and legs pitchy red. Length $1 \frac{3}{4}$ line.

M. Putzeys informs us that M. Reiche possesses a specimen which was captured in England, and that it is rather common on the opposite coast at Ostend. I have never met with it among our indigenous species, but take this opportunity of calling the attention of my brother-entomologists to an insect which has been secured in England by a foreign collector. Mr. Haliday, however, informs me that he has captured it on the sandy shores of Lough Neagh.

6. D. impunctipennis : capite thoraceque rotundato nigro-obscuris, elytris piceo-custaneis, oblongo-ovatis, profundè striatis, striis impunctatis, tibiis anticis extùs obsoletissimè bidenticulatis. (Pl. I. f. A.)

Beneath black, head-and thorax obscure black, sometimes pitchy; elytra deep pitchy chestnut, sometimes æneous. Head with an oblong depression behind the eyes, palpi and antennæ rusty red, the base palest. Thorax obovate, truncate in front, very slightly narrowed below the anterior angles, sides gradually rounded, globose behind; disk convex with an impressed central line terminating in front in the usual transverse impression, which latter is bordered by numerous longitudinal striæ. Elytra oblong-ovate, obliquely sloped in front towards the shoulders which are elevated, the sides very moderately rounded, convex, deeply striated, the strice deepest at the base next the suture, all the stria impunctate, except that in an occasional example some 
obsolete impressions are discernible under a magnifying glass scattered here and there irregularly; the anterior tibix terminate in two strong spines, of which the outer one is stoutest, rather longest and incurved, they are also furnished externally with two very obsolete teeth. Length 2 lines.

I captured three examples of this very distinct species, which I have now described for the first time, by a stream on the Smallmouth sands near Weymouth.

7. D. thoracicus : aneus, nitidus, thorace rotundato, elytris ovatis subtilitèr punctato-striatis, striâ marginali per basin continuatâ, tibiis anticis extùs acutè bidentatis.

Scarites thoracicus, Fab. S. El. 1. 125.

Clivina thoracica, Gyll. Ins. Suec. 2. 170.-Dej. Spec. 1.426 ; Icon. 1. 224. pl. 24.

Dyschirius thoracicus, Erichson, Käfer, 36.-Heer, Faun. Helv. 16.-Putz. Mon. 13. 4.

D. arenosus, (Leach) Steph. Mand. 1. 41, et Manual, p. 12.

Clivina nigra + , Ahrens, Archiv, no. 10.

Above brassy or bronzed, sometimes pitchy. Head small, deeply foveated on each side between the eyes, with two elevated transverse ridges in front; mouth, mandibles (except the tip which is black), basal joint of the antennæ, and base of the two next joints red. Thorax very globose with a strong dorsal furrow, deepest at the base, and the usual transverse impression, bordered on both sides by numerous fine longitudinal strix in the $\delta$. Elytra exactly ovate, slightly narrowed in front, shoulders rounded off, sides also rounded and a little narrowed at the apex, distinctly but finely punctate-striated, more faintly so at the extremity, the third interstice with three impressions, the upper one sometimes wanting, the marginal stria carried over the shoulder; anterior tibiæ acutely dentate externally (PI. I. f. 15), the apical tooth largest; legs (except the anterior femora) ferruginous. Length $1 \frac{3}{4}$ line.

The more ovate and less parallel form of this insect distinguishes it from any of the foregoing except impunctipennis, from which it differs in having the striæ distinctly punctured, and by the acute denticulations of the anterior tibiæ, as well as in other particulars. D. arenosus of Stephens's collection is an immature example of this species.

This insect is found in great profusion on the sands near the Chesil Beach, Isle of Portland; at Bridlington, Yorkshire; and also on many other parts of the coasts of England, Scotland and Ireland. 
8. D. jejunus: capite thoraceque nigro-aneis, capite rugoso, thorace ovato, elytris aneis, elongatis, crebrè punctatostriatis, tibiis anticis extùs fortiter bidentatis. (Pl. I.f.B.)

This insect has the head and thorax brassy black, the former rather obscure; elytra brassy or brownish brass. Head rugose, transversely strigose in front, with some traces of a longitudinal elevation, which is lost in the rugosity which entirely covers the head; mouth, mandibles, base of the palpi and three joints at the base of the antennæ red. Thorax ovate, very slightly narrowest in front, rather widest about the region of the posterior angles, convex, having a distinct dorsal furrow deepest at the base and towards the apex and the usual transverse impression in front, which is strongly striated longitudinally both above and below, the disk of the thorax being otherwise wrinkled. Elytra elongate, shoulders slightly elevated, sides appearing at first sight parallel, but in reality widest in front and a little narrowed behind, apex rounded, very finely punctate-striated, more faintly so before the apex, interstices flat; legs red, anterior tibiæ furnished with two long spines at their extremity of equal length, but the outer one much stouter, slightly curved and obtuse at the tip; armed likewise externally with two distinct strong obtuse teeth, the lower one largest. Length $1 \frac{3}{4}$ line.

We are indebted to the exertions of Mr. Bold of Newcastle for the discovery of this unique species. Two examples were captured by him on a damp sandy bank by the river Irthing a little above Lanercost Abbey, Cumberland, in June. They were returned to him from Paris as entirely unknown. Mr. Bold having kindly placed them at my disposal for the purpose, I have for the first time introduced them as a new species.

9. D. æeneus : aneus, nitidus; thorace breviter ovato, elytris oblongo-ovatis, punctato-striatis, striâ marginali ad humerum abbreviatâ, tibiis anticis extùs acutè bidenticulatis.

Clivina anea, Dej. Spec. 1. 423; Icon. 1. 221. pl. 24.

Dyschirius aneus, Steph. Mand. 1. 42, et Manual, p. 12.Erichson, Käfer, 39.-Heer, Faun. Helv. 17.-Putz. Mon. 27.23.

D. thoracicus, Steph. Mand. 1. 41, et Manual, p. 11.

D. tristis, Steph. Mand. 1. 43, et Manual, p. 12.

D. aratus, Haliday, Zool. Journal.-Steph. Mand. 1. 178, et Manual, p. 11.

D. pusillus, Steph. Mand. 5. 370, et Manual, p. 12.

Above brassy, bronzed or bluish black. Head transversely strigose in front, having a deep oblong fovea on each side ; mandibles, base of the palpi and of the antennæ red. Thorax ovate, 
truncate in front, rather widest behind the middle, with a distinct dorsal line bordered by some transverse wrinkles and with the usual impression in front furnished with numerous rugose longitudinal strix in the $\delta$, glabrous in the $q$. Elytra ovate, convex, base sloped towards the humeral angles which are prominent, sides rather narrowed in front, then rounded, and the apex a little contracted, punctate-striated, more faintly at the extremity, interstices with three impressions; the anterior tibix armed with two distinct teeth, of which that at the apex is largest, longest and most acute. Length $1 \frac{1}{2}$ line.

This species is variable in form and somewhat in colour. M. Putzeys quotes four varieties, all of which blend more or less into each other. The first, which may be considered the type, as it comprehends the greatest number in the Dejeanian collection, has the thorax rather narrowed in front, the anterior angles rectangular, and the elytra about twice as long as they are wide, their base truncate, shoulders prominent, sides widest towards the middle and contracted behind, the striæ unequal but distinctly marked to their extremity. The second variety has the thorax narrower and very globose. The third has the thorax also narrower, but more elongate, more contracted before and behind, the elytra are wider and the strix more regular, and the punctures coarser. The fourth variety has the elytra longer and their base more rounded.

D. tristis, Stephens, is a dark variety of this species, to which also cratus, Haliday, and pusillus, Stephens (not Dejean), must be referred. The true Clivina pusilla, Dej., is from the Caucasus.

This species is widely distributed, and occurs in England, Scotland, and (very rarely) in Ireland. I have taken it in profusion in the muddy deposits in the fens about Whittlesea Mere. The variety aratus, with a fold down the forehead, was found near Holywood in Ireland. Some remarkably slender examples occur in the Isle of Wight, and both there and at Whittlesea Mere occasional specimens of the black or blue-black variety are found.

10. D. globosus : nigro-aneus, nitidus ; thorace rotundato, elytris ovatis, striato-punctatis, apice lavibus, tibiis anticis extùs bidenticulatis.

Scarites globosus, Herbst, Archiv, 142. 58. t. 29 (1783).

Dyschirius globosus, Putz. Mon. 19. 12.

Scarites gibbus, Fab. Ent. S. 1.96 (1792).

Clivina gibba, Gyll. Ins. Suec. 2. 171.-Dej. Spec. 1. 428;

Icon. 1. 227. pl. 25. 
Dyschirius gibbus, Steph. Mand. 1. 43, et Manual, p. 12.

Clivina minima, Ahrens, Archiv. no. 13.

Dyschirius minimus, Curtis, Ent. pl. 354.-Steph. Mand. 5. 370, et Manual, p. 12.

Bronze or bluish brass. Head with a deep oblong fovea on each side enclosing a strongly elevated ridge between them; mouth, base of the palpi and of the antennæ red. Thorax very convex, sides rather globose, finely channeled down the centre and transversely wrinkled. Elytra ovate, not much wider in front than the thorax, shoulders rounded, sides dilated at the middle, apex again narrower and rounded, very convex, strongly punctate-striated, the punctured striæ vanishing before the apex, and the marginal one abbreviated at the shoulders; legs pitchy red, sometimes paler, femora occasionally darker, anterior tibiæ armed with two minute teeth externally, the apical one most distinct. Length 1 line.

This insect is commonly distributed and usually occurs in great abundance. The small variety described by Mr. Curtis under the name minimus presents no constant characters, beyond its uniform inferiority in size, to separate it satisfactorily, and is now, I believe, generally admitted to be a small local variety. It is found in vast profusion on the alluvial deposits in the vicinity of Whittlesea Mere, in May and June. Also in many other parts of the kingdom both inland and on the coast.

Subfam. 3. Carabides, Westwood.

Genus 11. CYCHRUS, Fabricius.

Mentum dente medio nullo. Ligula minuta subacuminata; paraglossis vix ullis. Palpi articulo ultimo fortitèr securiformi. Mandibulæ elongatae angustatæe intùs dentate. Labrum bifidum. Tarsi in utroque sexu simplices.

1. C. rostratus : ater; thorace angustato, posticè transversìm impresso, angulis posticis subrotundatis elevatis; elytris ovatis punctato-granulatis margine carinatis.

Tenebrio rostratus, Linn. F. S. 923 ; S. N. 2.677.

Cychrus rostratus, Fab. S. El. 1. 165.-Gyll. Ins. Suec. 2.71.Dej. Spec. 2. 8; Icon. 1. 260. pl. 28.-Steph. Mand. 1. 45, et Manual, p. 13.-Curtis, Ent. pl.426.-Erichson, Käfer, 11.

Deep black. Head very narrow and elongate, slightly rugosepunctate, with an elevated line on each side at the base of the antennæ, the apex of the latter ferruginous. Thorax narrow, truncate in front, sides rounded and widest in the middle, con- 
tracted behind, posterior angles subrotundate and elevated, disk finely but thickly rugose-punctate, with the usual dorsal furrow slightly impressed, base with a deep transverse depression. Elytra wide, ovate, very convex, the apex slightly acuminated, having a distinct furrow on each side and the margins strongly inflexed, the entire surface finely punctured and granulated and marked with three obsolete interrupted lines which together with the suture are rather more elevated; body beneath shining black, legs elongate. Length 8 lines.

Widely distributed and frequently abundant in sand and gravel pits, under stones and among dead leaves in woods throughout the kingdom.

\section{Genus 12. CARABUS, Auctorum.}

Mentum dente medio lobis lateralibus aquali. Ligula brevis, levitèr acuminata; paraglossis coriaceis, ei contiguis, eamque superantibus. Palpi articulo ultimo securiformi. Mandibulæ unidentata, incurva. Labrum breve, apice plerumque emarginatum. Tarsi antici maris articulis quatuor dilatatis, subtùs spongiosis.

1. C. intricatus : elongatus, cyaneus; thorace subcordato, angulis posticis acuminatis; elytris rugosis triseriatim subtuberculatis.

Linn. F. S. 780.-Oliv. Ent. 3. 35. pl. 20.-Gyll. Ins. Suec. 2. 54.-Steph. Mand. 1. 47, et Manual, p. 14.-Erichson, Käfer, 12.

C. cyaneus, Fab. Mant. 1. 195.-Fab. S. El. 1. 171.-Dej. Spec. 2. 176 ; Icon. 2. 33. pl. 67.

Head large, black with a violet tinge, forehead rugose with a deep impression on each side; four joints at the base of the antennæ black and glabrous, the remainder fuscous and pubescent. Thorax somewhat cordate, attenuated behind, the margins elevated and the posterior angles acuminated, disk transversely rugose on each side the dorsal furrow, cyaneous or greenish with the margins blackish. Elytra elongate, rather wider than the thorax, sides dilated beyond the middle, apex obliquely sinuated, deep violaceous, covered with rugose irregular elevated striæ, each elytron with three more distinct scries of elevated oblong tubercles of a bronze colour forming interrupted lines; underside of the body glossy blue-black; legs black. Length 12-14 lines.

This grand species is very rare in this country, and appears to be almost exclusively confined to the south-west district border- 
ing on the Forest of Dartmoor. The first specimen was captured by Dr. Leach near Tavistock and is in the British Museum. It was subsequently found near Holsworthy and Ashburton. Four or five individuals were taken from under the moss and lichens growing on the lower part of the trunks of trees in the woods at Bickleigh Vale, Devonshire, by the Rev. Mr. Hoare of Devonport, two of which are unfortunately lost to this country. The only example which has occurred in the vicinity of the metropolis, as far as I am aware, is in the collection of W. Stanhope Taylor, Esq., who himself found it in a stable at Croydon.

2. C. catenulatus : oblongo-ovatus, niger, thoracis limbo elytrorumque margine cyaneis; elytris crenato-striatis, interstitiis subrugosis punctisque excavatis triplici serie.

Scopoli, Ent. Carn. 86 (1763).-Fab. Ent. S. 1. 125 (1792).Fab. S. El. 1. 170.-Gyll. Ins. Suec. 2. 57.-Dej. Spec. 2. 68; Icon. 1. 321.pl. 42.-Steph. Mand. 1.48, et Manual, p. 14.Erichson, Käfer, 14.

Oblong-ovate, black, head and thorax sometimes with a violet tinge, margins of the thorax and elytra cyaneous. Head obsoletely punctulated and strigose, antennæ black and glabrous at the base, the upper joints fuscous and pubescent. Thorax cordate, the lateral margins considerably elevated and produced behind, densely rugose-punctate, the dorsal line very slender. Elytra oblong-ovate, much wider than the thorax, black, with the margins bright violaceous or cyaneous, with about sixteen elevated and interrupted lines on each, the third, seventh and eleventh from the suture more elevated than the rest, having also some larger remote punctures, the interstices granulated and rather rugose; underside of the body and legs wholly black. Length 10-12 lines.

Abundant throughout the kingdom, and in profusion on the Welch Mountains.

3. C. monilis : oblongo-ovatus, aneus, viridis, interdum violaceus; elytris elevato-trilineatis linea media magis elevatâ, tuberculisque oblongis interruptis triplici serie alternis.

Fab. Ent. S. 1. 126.-Fab. S. El. 1. 171.-Sturm, D. F. 3. 64. -Dej. Spec. 2. 73 ; Icon. 1. 326. pl. 43.-Steph. Mand. 1. 49, et Manual, p. 14.-Heer, Faun. Helv. 22.

Var. $\beta$. C. consitus, Panz. Faun. 108. 3.-Steph. Mand. 5. 371 , et Manual, p. 14.

Above green coppery or more rarely violaceous. Head rugosely punctate with a shallow depression on each side and an elevated 
irregular ridge between it and the antennæ, the four basal joints of the latter with the mandibles and palpi black and shining, the rest of the antennæ fuscous. Thorax short, margins broadly reflexed especially at the hinder angles which are produced, finely granulated and rugose. Elytra oblong-ovate, narrowest in front, margins reflexed, having three series of elevated interrupted lines so as to present the appearance of oblong tubercles more or less raised: between these elevated lines are three raised striæ, of which the intermediate one is most elevated and together with the suture usually blackish, the interstices regularly punctulate and the margins coarsely rugose and granulated; body beneath and legs shining black. Length 11-13 lines.

This species is pretty generally distributed. C. consitus is only a longer and more distinctly marked variety, having the longitudinal lines and raised tubercles on the elytra more elevated. Purple varieties of monilis occasionally occur, but the large and handsome purple, blue or grass-green examples of the variety $\beta$. so common in France, are not found in England.

4. C. arvensis : oblongo-ovatus, viridi-aneus cupreus; elytris elevato-striatis, tuberculis oblongis elevatis triplici serie interstitiisque obsoletè punctatis.

Fab. Mant. 1. 196 (1787).-Fab. S. El. 1. 174.-Payk. Mon. 21.-Gyll. Ins. Suec. 2. 61.-Dej. Spec. 2.75; Icon. 1.3. 30. pl. 44.- Steph. Mand. 1. 51, et Manual, p. 15.-Erichson, Käfer, 15.-Heer, Faun. Helv. 23.

Oblong-ovate, much smaller than the preceding species; above greenish or brilliant reddish copper or brassy. Head as in the preceding species. Thorax narrower, sides rounded, the margins reflexed and the posterior angles produced and rounded, the surface distinctly punctured and wrinkled, having an impressed fovea on each side at the base. Elytra oblong-ovate, rather narrowed in front, widest behind the middle, having on each elytron a triple series of elevated oblong tubercles, between which are three raised strix, the middle one broadest and most conspicuous with a few irregular punctures on it and the interstices very regularly and faintly punctured, the margins rugose and granulated with a row of small raised tubercles in front; underside of body and the legs black. Length 8-10 lines.

A very variable insect in colour; the more brilliant coppery examples are most frequent, but occasionally individuals occur which are entirely violaceous or very dark brassy black. It is somewhat local, but far from uncommon in the spring on sandy heaths in the south of England, particularly in and near the 
New Forest, Hants, and at Poole, Dorset. It is found in Lipping Forest and on Wimbledon Common, and Mr. Dale has captured it in Cumberland and Westmoreland, and Dr. Leach in the Isle of Arran. I found a dark blue variety also on Snowdon. "Hills near Belfast," A. H. Haliday, Esq.

5. C. granulatus : oblongus, subdepressus, obscurè fusco-ceneus ; thorace quadrato, angulis posticis vix productis; elytris elongatis, costis integris elevatis tuberculisque oblongis triplici serie alternis, interstitiis subrugosis.

Linn. F. S. 781.-Müller, Prod. Zool. Dan. 75 (1776).-Gyll. Ins. Suec. 2. 62.-Dej. Spec. 2. 106 ; Icon. 1. 361. pl. 51.Steph. Manual, p. 14.

C. cancellatus, Fab. S. El. 1. 176.-Sturm, D. F. 3. 49.Steph. Mand. 1. 50.-Erichson, Käfer, 16.-Heer, Faun. Helv. 24.

Above fuscous brassy or brassy black, sometimes greenish, rather depressed. Head narrow, finely punctured, having on each side an oblong impression, and an elevated fold between that and the antennæ. Thorax quadrate, rather small, with the posterior margins elevated and the hinder angles very slightly produced, disk rugosely punctured, base depressed and with two foveæ. Elytra oblong, sides very little widest behind, apex slightly acuminated, each elytron with three series of elevated oblong tubercles, and three elevated lines alternately, the interstices being also finely granulated and the margins furnished with a continuous series of small raised tubercles, and otherwise coarsely granulated; body beneath and legs black. Length 8-10 lines.

Abundant in damp marshy places in rotten willows, on banks of pools under refuse, \&c. throughout the kingdom.

6. C. cancellatus : oblongus, fusco-ceneus; elytris costis integris elevatis tuberculisque oblongis triplici serie alternis, interstitiis subrugosis; antennarum articulo primo rufo, femoribus interdùm rufis.

Ill. Käfer, 1. 154.-Gyll. Ins. Suec. 2. 64.-Dej. Spec. 2. 99 ; Icon. 1. 351. pl. 49.-Steph. Manual, p. 15.-Erichson, Käfer, 15.-Heer, Faun. Helv. 23.

C. granulatus, Fab. Mant. 1. 197.-Fab. El. 1. 176.-Sturm, D. F. 3. 42.-Steph. Mand. 1. 51. pl. 4.

This species is nearly allied to the preceding, but is usually larger and more convex; the thorax is more narrowed behind, and the elytra more ovate and the colour usually brighter; the 
basul joint of the antenna is large and red and the thighs occasionally red also. Length 8-10 lines.

Stephens informs us that "four examples only of this insect have occurred in Britain; they were taken in a chalk-pit near Gravesend in the spring of 1826."

7. C. clathratus : oblongo-ovatus, nigro-aneus; elytris costis tribus integris elevatis foveisque aureis triplici serie alternis.

Linn. F. S. 782.-Fab. S. El. 1. 176.-Gyll. Ins. Suec. 2.67.Sturm, D. F. 3. 102.-Dej. Spec. 2. 108 ; Icon. 1.363.pl.51.Steph. Mand. 1. 54, et Manual, p. 15.-Erichson, Käfer, 16.Heer, Faun. Helv. 25.

Head black, obsoletely punctate and strigose, with an oblong fovea and an elevated ridge on each side; four joints at the base of the antennæ black, the rest fuscous and pubescent. Thorax quadrate and short, rather narrowed in front, sides rounded, margins elevated especially behind, posterior angles rounded, disk brassy black, with a deep central furrow profoundly impressed about the middle and on each side behind a deep bilobed fovea, very finely punctulated throughout. Elytra narrowed in front, dilated behind the middle, greenish or brownish brass or fuscous black, with three elevated ribs, the one close to the suture being less elevated, the interstices finely granulated, each with a single row of deep round coppery or golden foveæ, and between every two an oblong raised tubercle presenting the appearance of an elevated interrupted line, the margins finely granulated and with a continuous series of small round coppery foveæ; under side of the body and legs shining black. Length 11-13 lines.

This insect is reported to have been taken several years ago in Halvergate Marsh, Norfolk. It is very abundant on the coast of Ireland and in many parts of Scotland. "Clova mountains, Forfarshire; abundant in Mull, Hebrides, \&c." Murray's Catalogue of Scottish Coleoptera.

8. C. auratus : oblongo-ovatus, viridis; elytris costis tribus elevatis, interstitiis sublavibus; antennarum basi, pedibusque rufis.

Linn. F. S. 786.-Fab. S. El. 1. 175.-Gyll. Ins. Suec. 2.68.Sturm, D. F. 3. 33.-Dej. Spec. 2.111 ; Icon. 1. 367. pl. 53.Steph. Mand. 1.55. pl. 3, et Manual, p. 16.-Erichson, Käfer, 17.-Heer, Faun. Helv. 25.

Head green, rather coppery in the middle, punctured and rugose, having an oblong impression on each side; mouth, mandibles and four joints at the base of the antennæ red, tip of the mandibles pitchy and the upper joints of the antennæ fuscous. 
Thorax short, truncate in front, sides rounded, contracted behind and the posterior angles produced and rather acuminated, shining green, with the centre and margins golden green, punctured and transversely strigose, having an indistinct fovea on each side at the base and a well-marked central line. Elytra oblong-ovate, narrowed in front, apex notched and acuminated, brilliant golden green, the suture and margins reddish copper, each elytron with three elevated obtuse costæ abbreviated before and behind, interstices deeply channeled and very finely granulated, margins with a series of deep punctures; legs red. Length 10-12 lines.

Of rare occurrence in England, though very abundant on the French coast. It has been taken near Dover, Southampton and Exmouth; I have an example which was captured near Lowestoff. It has also been found at Lough Bray in Ireland by Mr. Coulter.

9. C. nitens : ovatus, aureo-cupreus; elytris viridibus, margine aureis, suturâ costisque tribus elevatis nigris, interstitiis transversim rugoso-reticulatis.

Linn. F. S. 785.-Fab. S. El. 1. 177.-Gyll. Ins. Suec. 2.70.Sturm, D. F. 3. 37.-Dej. Spec. 2. 121 ; Icon. 1. 377. pl. 55.Steph. Mand. 1. 56, et Manual, p. 16.-Erichson, Käfer, 17.

Head and thorax more or less brilliant coppery red or greenish, the former narrow and finely punctured. Thorax narrow in front, sides equally rounded, posterior angles rounded and very slightly produced, disk finely punctured throughout, the dorsal line and basal foveæ very slight. Elytra ovate, narrower in front, silken green with the margins reddish copper, the suture and three elevated, more or less interrupted costæ on each obscurely coppery or blackish, interstices deeply channeled and finely rugose, somewhat reticulated; body beneath and legs black. Length 7-8 lines.

Abundant in the south of England, in the New Forest and on Parley Heath and near Poole ; also in Yorkshire, Durham, and in Scotland; and near Belfast in Ireland.

10. C. violaceus : elongatus, niger, thoracis limbo elytrorumque margine violaceis, elytris subtiliter granulatis.

Linn. F. S. 787.-Fab. S. El. 1. 170.-Gyll. Ins. Suec. 2. 56.Dej. Spec. 2. 132 ; Icon. 1. 389. pl. 58.-Steph. Mand. 1.52, et Manual, p. 15.

C. purpurascens, Fab. S. El. 1. 170.-Steph. Mand. 1. 48, et Manual, p. 15.

C. exasperatus, Curtis, Ent. pl. 446.-Steph. Mand. 5. 371, et Manual, p. 15.

Head black and rugose, with a fovea on each side behind 
the antennæ, four joints at the base of the latter black and glabrous, the remainder fuscous and pubescent. Thorax quadrate, slightly dilated between the anterior angles and the middle, broadly margined behind, with the posterior angles deflexed and produced, disk rugosely punctate, black with the lateral margins broadly violaceous. Elytra black, convex, elongate, narrow at the shoulders, dilated in the middle, finely granulated, sometimes the granules are united here and there so as to form slightly elevated lines but irregularly disposed, margins broad, subpunctate, bright coppery or golden violet or brilliant purple; body beneath and legs black. Length 12 lines.

Common in gardens, in gravel-pits and on heaths and pathways, \&c. in the spring; very abundant in the south and midland counties of England; in Scotland and in Ireland.

C. purpurascens, Fab., is a variety of this insect ; and C. exasperatus, Dufts., has no indigenous examples to confirm it; the individuals published under that name and captured in the Isle of Portland are likewise varieties of this species.

\section{C. convexus : niger, limbo cyaneo; elytris convexis, subtiliter crenato-striatis triseriatim punctatis.}

Fab. Mant. 1. 197.-Fab. S. El. 1. 175.-Gyll. Ins. Suec. 2.61. -Dej. Spec. 2.158; Icon. 2. 17.pl. 63.-Steph. Mand. 1. 53. pl. 4, et Manual, p. 15.-Erichson, Käfer, 13.

Shorter and narrower than glabratus, black with the margins of the thorax and elytra cyaneous. Head slightly punctured and with an impression on each side between the antennæ. Thorax nearly quadrate, very slightly narrowest behind, the basal margin deeply notched, the posterior angles rounded, disk with a slight dorsal line and very much punctured and rugose. Elytra short, ovate, convex, closely striated, the striæ obsoletely punctured, with narrow elevated granulated interstices and three series of larger impressions ; underside black and shining. Length 8 lines.

A doubtful native; there are two examples in the British Museum; one in the collection of Mr. MacLeay and another in that of Mr. Vigors, but the locality of none of them is known. The Rev. A. Matthews informs me that he has an example which was taken in Winstanley Park in Sept. 1835.

12. C. glabratus : oblongo-ovatus, niger; thorace tenuitèr reticulato-rugoso ; elytris convexis, subtilissimè granulatis.

Payk. Mon. 14 (1790).-Fab. Ent. S. 1.125 (1792)._Fab. S. El. 1. 170.-Gyll. Ins. Suec. 2. 55.-Dej. Spec. 2. 136; Icon. 1. 
394. pl. 59.-Steph. Mand. 1.52, et Manual, p. 15.-Erichson, Käfer, 13.

Entirely black and somewhat glabrous. Head very minutely punctured and subrugose, with a short fovea on each side behind the antennæ, which are black and glabrous at the base, and the upper joints fuscous. Thorax subquadrate, narrowed in front, sides regularly rounded till behind the middle, then almost straight with the margins very broadly elevated and the posterior angles produced, disk crowded with minute flexuous punctures and wrinkles, appearing almost reticulated, the base and the lateral margins depressed. Elytra oblong-ovate, very convex, ninutely granulated, the granules on the margins being larger; underside of body shining black, sides rugose; legs black. Length 11-12 lines.

A mountain species, which is plentiful in the Highlands of Scotland and occurs also in the north of England, in North Wales and in Ireland. Stephens has recorded it as a remarkable fact that the first British specimen is stated to have been captured in Surrey, which is the only instance known of its occurrence in the south.

13. C. nemoralis : oblongo-ovatus nigro-aneus, thoracis limbo elytrorumque margine cupreo-violaceis, elytris subrugosis triseriatim foveolatis.

Müller, Prod. Zool. Dan. 75 (1776).-Ill. Käfer, 1. 152.Gyll. Ins. Suec. 2. 58.-Steph. Manual, p. 15.

C.hortensis, Fab. Mant. 1.196(1787).-Payk. Mon.16 (1790). -Dej. Spec. 2. 150 ; Icon. 2. 13. pl. 63.-Steph. Mand. 1. 53.-Heer, Faun. Helr. 27.

Head small, black, very shining, rugose in front and with a very deep impression on each side; four joints at the base of the antennæ black, the rest fuscous. Thorax subquadrate, margins a little elevated, posterior angles produced, brassy black, purplish or coppery, obsoletely punctate-rugose on the disk, more deeply so within the margins and at the base. Elytra oblong-ovate, fuscous brassy, coppery or bright metallic green, convex, with three series of large punctures connected by irregular oblong tubercles having somewhat the appearance of slightly elevated interrupted lines, the rest of the surface densely granulated or rugose; body beneath with the legs black. Length 10-12 lines.

Common.

Genus 13. CALOSOMA, Weber.

Mentum dente medio acuto, lobis lateralibus breviore. Ligula brevis, apice rotundata ciliata; paraglossis coriaceis ei con- 
tiguis eamque superantibus. Palpi articulo ultimo levitèr securiformi. Mandibulæ latæ, edentula, striolate. Labrum apice emarginatum. Tarsi antici maris articulis quatuor dilatatis, subtìs spongiosis.

1. C. Sycophanta : violaceum; elytris viridi-aureis, crenatostriatis punctis impressis triplici serie.

Carabus Sycophanta, Linn. F. S. 790.-Oliv. Ent. 3. 35.

Calosoma Sycophanta, Fab. S. El. 1.212.-Gyll. Ins. Suec. 2. 49.-Dej. Spec. 2. 193 ; Icon. 2. 48. pl. 70.-Steph. Mand. 1. 57, et Manual, p. 16.-Curtis, Ent. pl. 330.-Erichson, Käfer, 18.-Heer, Faun. Helv. 32.

Head small and porrect, blue-black, rugosely punctured, with an oblong impression on each side in front. Thorax very short, transversely oval, very much dilated and rounded at the sides, violaceous with the lateral margins more or less greenish, moderately convex, the dorsal line very faint, the base with a fovea near each hinder angle which is produced, and the whole disk rugosely punctured. Elytra very broad, the basal angles rounded and the apex rather acuminated, rich metallic green, crenate-striated, with three series of large impressions on the third, seventh and eleventh striæ; underside violet-blue, finely punctulated; legs black. Length 11-14 lines.

In its native haunts this splendid insect inhabits woods and forests: for an account of its habits in the pine forests of Silesia, see 'Zoologist,' p. 900 . In this country it is not truly indigenous, and we can lay claim to it as only an occasional visitant to our shores. It has been taken at Aldborough, Southwold and Lowestoff, Suffolk; Yarmouth, Norfolk; at Bristol and on the Devonshire coast; frequently at Brighton, near Herne Bay and Gravesend; in the Isle of Wight; and in Ireland. It has been reported to have occurred in a wood near Oxford, but on inquiry I have ascertained that the species in question was C. inquisitor.

2. C. inquisitor : viridi cupreo-ceneum; elytris punctato-striatis transversim rugosis punctis impressis triplici serie.

Carabus inquisitor, Linn. F. S. 789.

Calosoma inquisitor, Fab. S. El. 1.212.-Gyll. Ins. Suec. 2. 50. -Dej. Spec. 2. 194 ; Icon. 2. 49. pl. 70.-Steph. Mand. 1. 58, et Manual, p. 16.-Erichson, Käfer, 18.-Heer, Faun. Helv. 32 .

Head coppery with a greenish tinge, especially on the sides, produced in front, rugosely punctate, with two oblong foveæ, 
antennæ black with the tips fuscous. Thorax very short, dilated at the sides and rounded, contracted behind, coppery green, very shining, margins more brilliantly green, thickly rugose-punctate, margins elevated and more coarsely punctured and rugose, base with two deep foveæ. Elytra broad, more dilated behind the middle, coppery with the margins brilliant shining green, thickly punctate-striated, interstices transversely strigose, with three series of deeper impressions; body beneath violaceous with a greenish tinge on the sides of the abdomen, the underside of the thorax shining green and somewhat rugose, legs black. Length 8-10 lines.

Found on oaks in Windsor and Epping Forests ; Burghfield, Berks; White Wood, Tetworth, Camb.; Bagley Wood, Oxon ; New Forest; and Powerscourt, Ireland.

\section{Genus 14. LEISTUS, Fröhlich.}

Mentum dente lato, leviter emarginato. Ligula valdè elongata, acutè tricuspis; paraglossis ei multo brevioribus, apice acuminatis. Maxillæ extùs palmato-dentata. Palpi elongati, tenues, labiales articulo secundo maximè elongato. Labrum apice rotundatum. Tarsi antici maris articulis tribus dilatatis, subtùs densè spongiosis.

1. I. spinibarbis : cyaneus; thorace cordato, posticè subangustato; elytris punctato-striatis; antennis pedibusque rufotestaceis aut brunneis.

Carabus spinibarbis, Fab. Ent. S. 1. 137.-Fab. S. El. 1. 181. Leistus spinibarbis, Dej. Spec. 2. 214 ; Icon. 2. 59. pl. 72.Steph. Mand. 1. 63, et Manual, p. 17.

L. caruleus, Sturm, D. F. 3. 154.

L. nigricans, Newman, Ent. Mag. 1. 286.-Steph. Mand. 5. 373, et Manual, p. 17.

Broad and depressed, above shining cyaneous, or bluish green; mouth, palpi and antennæ red. Thorax with the sides dilated and rounded in front, contracted behind, with a distinct impressed central line, the disk on each side of it smooth and convex, the entire base together with a fovea near each hinder angle, and the anterior margin punctured, the lateral margins reflexed and finely punctutated. Elytra wide, oblong-ovate, apex rounded. punctate-striated, the third stria with some larger impressions; underside black, legs pitchy black, tarsi rusty red, the legs sometimes wholly red in less mature examples and the $m$ argins of the thorax also pale. Length 4 lines.

A very abundant species, of which $L$. nigricans, as its name imports, is a dark variety. 
2. L. fulvibarbis: subcyaneus; thorace cordato, posticè angustato; elytris punctato-striatis; antennis pedibusque rufis.

Dej. Spec. 2. 215 ; Icon. 2. 61. pl. 72.-Curtis, Ent. pl. 176.Steph. Mand. 1. 64, et Manual, p. 17.

L. Janus, Newman, Ent. Mag. 1. 286.-Steph. Mand. 5. 373, et Manual, p. 18.

L.indentatus, Newman, Ent. Mag. 1.286.-Steph.Mand.5.373, et Manual, p. 18.-Heer, Faun. Helv. 33.

This species is considerably smaller than the preceding; it is usually pitchy black with a more or less cyaneous tinge, antennæe and mouth red. Thorax proportionally more dilated and rounded at the sides, and shorter, with the lateral margins less elevated, and the posterior angles more prominent. Elytra distinctly punctate-striated, with some larger impressions on the third stria from the suture as in spinibarbis; legs entirely red. Length 3-3 $\frac{1}{2}$ lines.

It is found in immense profusion in marshy places in spring and autumn. L. Janus is an immature example of this insect, to which also $L$. indentatus must be referred.

\section{L. montanus: "caruleus, thoracis margine laterali ore} antennis pedibusque rufis."

Steph. Mand. 1. 64. pl. 4, et Manual, p. 18.

"Similar to the preceding (fulvibarbis), but known at once by its more elongated structure, and especially by the form of the thorax (Pl. I. f. 5); the upper surface is fine blue tinted with greenish on the head and thorax; the head is narrower and the eyes are less prominent than in L. fulvibarbis; the thorax is narrower, more depressed and elongated, it is divided by an impressed longitudinal line, the disk on each side being smooth, in front of the impression is a triangular space thickly sprinkled with impressed dots and a similar space covered with impressed dots behind, the margin is also punctated and the sides are rufo-ferruginous; the elytra are blue, with eight strix composed of impressed dots, and in the specimens which I have examined they are destitute of any impressions between the third and fourth striæ; the mouth, antennæ and legs are rufoferruginous, the latter dusky at the tips of the femora; beneath pitchy blue, with the pleuræ and sides of the abdomen deeply punctate. Length $3 \frac{1}{2}$ lines." - Mr. Stephens.

First taken by Messis. Dale and Curtis on Skiddaw; and subsequently by Mr. Marshall. It has also occurred on other 
mountains in the north of England, and in Scotland and Wales. It has been taken on Croagh Patrick in Ireland by Mr. Walker; and on Mangerton and Carran Tual, the highest peak in that island, by Mr. Haliday.

4. L. ferrugineus : rufo-ferrugineus; thorace brevi, cordato, posticè coarctato; elytris oblongo-ovatis, punctato-striatis ; antennis pedibusque pallidis.

Carabus ferrugineus, Linn. S. N. 2. 672.

C. spinilabris, Fab. S. El. 1. 204.

Leistus spinilabris, Dej. Spec. 2. 217 ; Icon. 2. 64. pl. 73.Steph. Mand. 1. 65, et Manual, p. 18.

Carabus rufescens, Payk. Mon. 58.-Duft. Faun. 2. 53.

Leistus rufescens, var., Sturm, D. F. 3. 158.

Entirely ferruginous. Thorax very short, and much dilated and rounded at the sides before the middle, thence suddenly and considerably contracted behind, posterior angles right angles, disk very convex, smooth and shining, the anterior and posterior margins thickly punctured. Elytra oblong-ovate, much narrowed in front and the angles rounded, dilated behind the middle, punctate-striated; body beneath pitchy red or ferruginous according to maturity, thorax and sides of the breast thickly punctured. Length 3 lines.

In profusion in marshy localities and generally distributed.

In the Linnæan Collection this insect is labelled "ferrugineus," with the label to that effect attached to the pin.

5. L. rufescens: rufo-ferrugineus, vertice elytrorumque apice nigris ; thorace cordato, posticè coarctato ; elytris punctatostriatis, antennis pedibusque pallidis.

Carabus rufescens, Fab. Mant. 1. 204 (1787).-Fab. S. El. 1. 205.-(var. $\beta$.) Payk. Mon. 58 (1790).

Leistus rufescens (var. b.), Sturm, D. F. 3. 158.-Steph. Mand. 1. 65, et Manual, p. 18.

Carabus praustus, Fab. Ent. S. 1. 162 (1792).

Leistus terminatus, Dej. Spec. 2. 218; Icon. 2. 65. pl. 73.

Head brownish black; mouth, palpi and antennæ testaceous. Thorax ferruginous red, convex, sides very much dilated and rounded, narrowed behind, posterior angles obtuse. Elytra oblong-ovate, narrowed in front, the apex more rounded, ferruginous red, with the tip occasionally brownish black; abdomen brownish black, legs pale testaceous. ILength $3 \frac{1}{4}$ lines. 
Widely distributed, but rather local. "Darenth and Coombe Woods;" Midland Counties; more abundant in the North; Midgley Moor; "Castle Eden Dene; Long Benton; South Shields;" and on the moors near Llangollen in Wales, in the spring and autumn. .

\section{Genus 15. INEBRIA, Latreille.}

Mentum dente medio parvo bifido. Ligula apice subacuminata, paraglossis ei contiguis, eamque vix superantibus. Palpi articulo ultimo cylindrico. Labrum apice truncatum, vel obsoletè sinuatum. Tarsi antici maris articulis tribus subdilatatis, subtùs parciùs spongiosis.

1. N. complanata : pallidè flavescens; elytris punctato-striatis, fasciis duabus abbreviatis undatis nigris.

Carabus complanatus, Linn. S. N. 2. 671.

Nebria complanata, Steph. Mand. 1. 59, et Manual, p. 16.

Carabus arenarius, Fab. S. El. 1. 179.

Nebria arenaria, Dej. Spec. 2. 223 ; Icon. 2. 73. pl. 74.

Broad and entirely pale ochreous yellow, with the inside of the mandibles and two irregular transverse bands on the elytra formed of elongate streaks more or less confluent together with the suture in front black or brownish black. Head very finely striated longitudinally on each side between the eyes. Thorax broad and short, the anterior margin forming in the middle a small obtuse angle, and the anterior angles also produced, sides widest about the middle, rather narrowed behind, posterior angles acute, sides broadly margined, disk strigose with a faint dorsal line and a transverse impression before and behind, and two obscure foveæ at the base. Elytra oblong, shoulders rounded, sides almost parallel, apex rounded, disk rather depressed, punctate-striated, margins punctured; the bands on the elytra are sometimes entirely effaced and occasionally only a small black dot is left, but the latter variety is said to be more common in France, where the insect is better known under the Fabrician name arenaria. Length 8-9 $\frac{1}{2}$ lines.

This species is very abundant on sandy coasts in the west of England; at Swansea; Barnstaple; Bideford; Weston-superMare; and on the Lincolnshire coast. "A single specimen (half-dead) was found on the Arklow sands by Mr. Furlong." A. H. Haliday, Esq. 
2. N. livida : nigra, thoracis medio elytrorum limbo latè antennis pedibusque pallidè testaceis.

Carabus lividus, Linn. S. N. 2. 670.

Nebria livida, Gyll. Ins. Suec. 2. 38 .

Carabus sabulosus, Fab. S. El. 1. 179.

Nebria sabulosa, Dej. Spec. 2. 224 ; Icon. 2. 74. pl. 74.

Var. $\beta$. elytrorum limbo angustè pallido, femoribus interdùm infuscatis. Illiger.

Carabus lateralis, Fab. S. El. 1. 180.

Nebria lateralis, Dej. Spec. 2. 225.

N. livida (var. b.), Gvll. Ins. Suec. 2. 38.

N. livida, Curtis, Ent. pl. 6.-Steph. Mand. 1. 60, et Manual, p. 16.

This species is smaller, narrower and more elongate than complanata. Head obscurely black, with a depression in the centre, and a rough shallow fovea on each side between the eyes; mouth, palpi and antennæ pale testaceous. Thorax testaceous, with the anterior margin and the base brownish black and broadly depressed, the width much greater than the length, the sides dilated and rounded at the middle, and the anterior angles rather produced, much narrowed behind, posterior angles obtuse but rather elevated, the lateral margins broadly reflexed and punctured, disk with a short central line terminating before and behind in the transverse depressions above mentioned, base with two foveæ. Elytra oblong, depressed, rounded at the shoulders, sides almost straight, brownish black with the margins pale testaceous, punctate-striated; underside obscure black, sides of the head transversely strigose beneath the eyes, sides of the thorax testaceous, finely rugose-punctate, sides of the abdomen coarsely punctured, apex testaceous, legs pale testaceous. Length 7-8 lines.

British examples of this species must be referred to the variety lateralis as they present the true characters of the Fabrician insect, having the yellow margins of the elytra considerably narrower than in the typical livida. The insect is local, but may be taken abundantly near Bridlington and Scarborough, by splitting open the crevices in the mud cliffs all along the shore.

(Helobia, Leach.)

3. N. brevicollis : nigra, subdepressa, elytris crenato-striatis, strià tertiâ quadripunctatâ; antennis tibiis tarsisque rufopiceis. 
Carabus brevicollis, Fab. S. El. 1. 191.

Nebria brevicollis, Gyll. Ins. Suec. 2. 39.-Sturm, D. F. 3. 140. -Dej. Spec. 2. 233 ; Icon. 2. 82. pl. 76.

Helobia brevicollis, Steph. Mand. 1. 61, et Manual, p. 17.

H. lata, Newman, Ent. Mag. 1. 284.-Steph. Mand. 5. 372, et Manual, p. 16.

H.varicornis, Newman, Ent. Mag.1.285.-Steph. Mand. 5.372, et Manual, p. 17.

Rather depressed, black or pitchy black, sometimes iridescent; antennæ red, and in less frequent examples with three or four joints near the base dusky. Thorax short, its sides dilated and rounded below the anterior angles and narrowed behind, broadly margined, all the margins coarsely punctured. Elytra depressed, shoulders a little rounded, sides nearly parallel, crenate-striated, interstices flat, the third stria with three or four larger punctures; underside black, head wrinkled, thorax finely, breast coarsely punctured; legs red, femora sometimes pitchy black. Length $4 \frac{1}{2}-6$ lines.

H. lata and varicornis are not distinct from this extremely abundant and widely distributed species.

4. IN. nivalis : nigra, subdepressa; elytris striatis, striis subpunctatis, punctis quatuor impressis ; antennis tibiis tarsisque rufo-piceis.

Carabus nivalis, Payk. Mon. 52.-Payk. Faun. 1. 119.

Nebria nivalis, Gyll. Ins. Suec. 2. 41.-Dej. Spec. 2. 237 ; Icon. 2. 86. pl. 76.-Heer, Faun. Helv. 36.

Helobia nivalis, Steph. Manual, p. 17.

H. Gyllenhallii, Curtis, Ent. pl. 103.-Steph. Mand. 1. 62.

H. Athiops, Steph. Mand. 1. 179, et Manual, p. 17.

H. Marshallana, Steph. Mand. 1. 61, et Manual, p. 17.

This species is smaller than brevicollis; beneath it is black, smooth and shining, with the thorax and sides of the breast very faintly punctured; above it is black or pitchy black, with the elytra sometimes reddish. Head with a shallow impression on the crown, and two obsolete foveæ between the antennæ; mouth, palpi and antennæ black, or pitchy black. Thorax very short, anterior angles produced, sides dilated and rounded at the middle, contracted behind, with broadly reflexed margins, the posterior angles acute and prominent, disk moderately convex, with a short central line terminating before and behind in a transverse depression coarsely punctured, base with two foveæ and disk otherwise obsoletely wrinkled. Elytra oblong, the shoulders narrower and more rounded than in brevicollis, sides very slightly widest behind the middle, apex obliquely sinuated, 
rather depressed, regularly striated, the striæ very finely punctured, with three or four larger impressions next the third stria between it and the second from the suture, and an irregular series (more or less deficient) on the marginal interstice touching the marginal stria; legs pitchy black, or entirely black, sometimes wholly red, or the femora red with their tips black. Length $4 \frac{1}{2}$ lines.

This species is found in great profusion on the Welsh mountains, as well as in Cumberland and the southern parts of Scotland, and in Ireland. I have examined hundreds of specimens which present every degree of variety that can be desired, to resolve into one species the insects recorded as distinct under the names Marshallana, Gyllenhallii, \&c. H. AEthiops is a broader and darker variety. There is another (very common on Snowdon) not noticed, with the body black and the legs entirely red.

\section{(Pelophila, Dejean.)}

5. N. borealis : obscurè anea; elytris striatis, foveis majoribus rotundatis duplici serie impressis.

Carabus borealis, Payk. Mon. 51 (1790).-Oliv. Ent. 3. 35. -Fab. S. El. 1. 182.

Nebria borealis, Gyll. Ins. Suec. 2. 42.

Pelophila borealis, Dej. Spec. 2. 263 ; Icon. 2. 117. pl. 84.Curtis, Ent. pl. 302.- Steph. Mand. 5. 390, et Manual, p. 61.

Head brassy black, with a shallow subrugose fovea on each side near the eyes; palpi and antennæ black. Thorax very short, anterior margin slightly sinuated and produced in the centre and at the angles, sides dilated and rounded before the middle, narrowed behind, broadly margined and the margins elevated, base truncate, hinder angles acute, glossy black, with a slight dorsal furrow, the anterior margin and the base thickly punctured and deeply depressed, the latter with two large foveæ. Elytra oblong-ovate, twice as wide as the base of the thorax, sides slightly rounded, the apex obliquely sinuated and a little acuminated, brassy black or brownish brass, obsoletely punctatestriated, the strix on the sides being nearly obliterated, the third interstice with four or five large impressions, and the fifth with two or three others; underside of the body black, legs sometimes wholly black, sometimes ferruginous, with the tip of the femora, tibiæ and joints of the tarsi dusky. Length 4-6 lines.

This species was originally captured on the sandy shores of Loch Neagh in Ireland, and has also been taken at Killarney 
and elsewhere. It is found in the Orkney Isles as well as in the west of Scotland, but the Irish examples are larger and more metallic than those found in Scotland.

\section{Genus 16. FIAPHRUS, Fabricius.}

Mentum dente medio bifido. Ligula obtusè rotundata, paraglossis apice liberis, angustis, linearibus, ligulam superantibus. Palpi articulo ultimo subovato, truncato. Mandibulæ inermes. Labrum truncatum. Tarsi antici maris articulis quatuor levitèr dilatatis, subtùs apice spongiosis.

* Prothorax truncato-cordatus, convexus.

1. E. uliginosus : viridi-aneus, punctatissimus; thorace capite latiore, fronte thoraceque foveolatis; elytris costis elevatis interruptis maculisque ocellatis violaceis quadruplici serie impressis.

Fab. S. El. 1. 245.-Dej. Spec. 2. 269 ; Icon. 2. 126 . pl. 85. -Gyll. Ins. Suec. 4.398.-Sturm, D. F. 7. 131.-Curtis, Ent. pl. 179.-Steph. Mand. 2. 33, et Manual, p. 60.-Erichson, Käfer, 5.-Heer, Faun. Helv. 40.

This species is abundantly distinct from the following; above it is brassy green. Head brilliant coppery green, finely and densely punctured, with a transverse ridge extending quite across between the antennæ, a shallow fovea on each side behind it, and a small impression on the crown. Thorax rather narrowed in front, sides much dilated and rounded in the middle, then suddenly narrowed, but with the posterior angles rectangular or very slightly prominent, the entire surface very minutely and densely punctured, with a large round deeply impressed fovea before the middle, and a smaller one on each side of it a little behind, and two others smaller than those below them, the large impressed fovea being continued, but rather shallow towards the base, before reaching which it becomes somewhat deeper and terminates in a small raised tubercle, also close to each posterior angle there is a deep large fovea, all these markings are much more distinct than in cupreus, and the fine punctuation that covers the entire surface is perfectly distinct and not at all confluent as it is in the allied species. Elytra ovate, very little widest behind the middle, finely punctate, each with three series of round ocellated impressions, and between every two of these impressions is an oblong, raised, smooth, shining tubercle, the interstices between these series of impressions and tubercles being formed of somewhat irregular raised 
costæ, on the margin there is a fourth series of round impressions but without any raised tubercles between them; the body beneath is shining green, underside of the thorax and sides of the breast punctured; femora brassy green, tibiæ and tarsi obscure black. Length $3 \frac{1}{2}-4$ lines.

Found at Whittlesea Mere and in the Cambridgeshre fens. "Coombe Wood; Swansea; Fyfield, Hants ; and Devonshire." Mr. Stephens. "In peat pits at Weston on the Green." Rev. A. Matthews.

2. E. cupreus : obscurè-ceneus, punctatissimus; thorace capitis latitudine, fronte thoraceque levitèr foveolatis; elytris maculis ocellatis quadruplici serie impressis.

Dufts. Faun. 2.194.-Dej. Spec. 2. 271 ; Icon. 2. 127. pl. 85. - Gyll. Ins. Suec. 4. 398. - Sturm, D. F. 7. 130.-Steph. Mand. 2. 34, et Manual, p. 61.-Erichson, Käfer, 5.-Heer, Faun. Helv. 40.

E. uliginosus, Gyll. Ins. Suec. 2. 6 .

This insect is brownish brass above, with somewhat of a purplish tinge on the elytra. Head very densely punctured, and with a transverse curved line in front, a shallow fovea on each side before the eyes and another behind them, and also a faint impression on the crown, but all these impressions are considerably less distinct than in uliginosus. Thorax wider in front than in that species, but the sides not nearly so much dilated in the middle, nor more narrowed at the base than in front, posterior angles acute and prominent, the surface more distinctly punctured, and the punctures somewhat confluent, the foveæ after the manner of the preceding, but much more indistinct and the largest bifid before it reaches the base, the two ends continued to the margin and forming a triangular space between them. Elytra ovate, sides rather widest behind the middle, the markings somewhat after the same manner, but the raised costæ very much interrupted and obsolete, or entirely wanting; underside of the body and the femora brassy green, tibiæ testaceous, tarsi cyaneous and shining. Length $3 \frac{1}{2}$ lines.

A very common and abundant species in marshes and damp woods; less frequent in Scotland. It is included also among the Irish Carabida.

3. $\mathbf{E}$ Lapponicus: oblongus, cupreo-aneus; capite thoraceque subfoveolatis; elytris parcè punctatis maculis ocellatis obsoletis quadruplici serie impressis. 
Gyll. Ins. Suec. 2. 8.-Dej. Spec. 2. 273; Icon. 2. 131. pl. 86. -Curtis, Ent. Mag. 1. 38.-Steph. Mand. 5. 390, et Manual, p. 61 .

Above brassy green, or coppery red, more or less shining. Head and thorax coarsely punctured, the former with a transverse line in front, but with the foveæ obsolete or scarcely perceptible. Thorax rather narrow, sides rounded at the middle and moderately contracted behind, posterior angles right angles, thickly and deeply punctured, with a short dorsal furrow which is bifid in front, and with a shallow fovea near each hinder angle. Elytra oblong-ovate, more elongate than either of the preceding, with the shoulders narrowed and rounded, the sides rather widest about the middle, disk with a few minute scattered punctures, and four rows of obscure ocellated round foveæ, and sometimes between those of the series next the suture there are three or four raised oblong shining spaces, but oftener deficient, these and the spaces between the fovex, as well as the intervals between the rows, being equally without elevations; body beneath greenish or purplish copper, with the head, thorax, sides of the breast, and femora punctured. Length $4 \frac{1}{4}$ lines.

"Taken on Catlaw and Clova mountains in Forfarshire" by Sir C. Lyell ; and at St. Kilda by Mr. J. M'Gillivray.

\section{E. riparius : viridi-aneus, punctatissimus; elytris maculis ocellatis quadruplici serie impressis.}

Cicindela riparia, Linn. F. S. 749 ; S. N. 2.658.

Elaphrus riparius, Fab. Mant. 1. 187; S. El. 1. 245.-Gyll. Ins. Suec. 2. 9.-Sturm, D. F. 7. 133.-Dej. Spec. 2. 274; Icon. 2. 132. pl. 86. - Steph. Mand. 2. 35, et Manual, p. 61. -Erichson, Käfer, 5.-Heer, Faun. Helv. 40.

Head coppery or brassy green, very densely and minutely punctured, without foveæ; antennæ greenish at the base, the upper joints fuscous black and pubescent. Thorax narrowed before and behind, sides rounded and dilated in the middle, brownish brassy, very minutely and densely punctured, with a dorsal line bifid in front, and an oblong fovea near each hinder angle. Elytra broad, dilated behind the middle, densely and minutely punctured, brownish brassy, with four rows of round ocellated foveæ; femora and tarsi green, tibiæ testaceous. Length 3 lines.

Abundant at Whittlesea Mere; common in damp marshy places near London; Carlisle; in Suffolk, \&c.; found also in Ireland and in Scotland. 
** Prothorax subquadratus, planiusculus.

\author{
(Blethisa, Bonelli.)
}

5. E. multipunctatus : obscurè aneus, limbo virescente, elytris punctato-striatis foveis magnis duplici serie impressis.

Carabus multipunctatus, Linn. F. S. 80j.-Fab. S. El. 1. 182. Nebria multipunctata, Gyll. Ins. Suec. 2. 44.

Blethisa multipunctata, Dej. Spec. 2.266 ; Icon.2.121. pl. 84 . -Sturm, D. F. 7. 124.-Steph. Mand. 2. 36, et Manual, p. 61.-Curtis, Ent. pl. 326.

Elaphrus multipunctatus, Erichson, Käfer, 6.-Heer, Faun, Helv. 41.

Brownish, or greenish brass. Head rather coppery in front, with a deep fovea on each side near the eyes, and behind these a transverse impression, the hinder part of the head finely and sparingly punctured. Thorax subquadrate, shortish, sides rather widest in the middle, broadly margined and the margins reflexed and punctured, rather narrowed behind, but with the base still broad and the posterior angles acute, the disk convex, with the dorsal furrow terminated before and behind by a transverse punctured depression, the base having also a deeply punctate impressed fovea on each side and an elevated fold externally running into the angle itself. Elytra broadly ovate, sides somewhat straight, disk convex, margins greenish, finely and irregularly punctate-striated, the interstices forming irregularly elevated ribs, the third interrupted with four or five, and the fifth with three or four large round deeply impressed shining brassy foveæ; body beneath coppery or greenish brass, sides of the thorax rugosely punctured, legs brassy black. Length $5 \frac{1}{2}$ lines.

Common at Whittlesea Mere and in the Cambridgeshire fens ; also near Sudbury, Suffolk ; in Essex ; near Carlisle, \&c. ; less frequent in Scotland; it is included also in Mr. Haliday's list of the Irish Coleoptera.

\title{
Genus 17. NOTIOPHILUS, Dumeril.
}

Mentum dente medio nullo. Ligula lata, apice acuminata ; paraglossis apice liberis, angustis, linearibus, ligulam vix superantibus. Palpi articulo ultimo subovato, truncato. Mandibulæ inermes. Labrum apice rotundatum. Tarsi antici maris articulis tribus vix dilatatis, subtùs densè spongiosis. 
1. N. aquaticus : aneus, nitidus; thoracis limbo punctato, lateribus obliquis parùm rotundatis; elytris extùs striatis, striis punctatis apice evanescentibus; antennis pedibusque totis nigris.

Cicindela aquatica, Linn. F. S. 752.

Elaphrus aquaticus, Fab. S. El. 1.246.-Gyll. Ins. Suec. 4. 399. Notiophilus aquaticus, Dej. Spec. 2. 277 ; Icon. 2. 136. pl. 87. -Sturm, D.F. 7. 142.-Steph. Mand. 2.32, et Manual, p. 60. N. Newmanii, Waterhouse, Ent. Mag. 1. 205.

N. metallicus, Waterhouse, Ent. Mag. 1. 203.

Above brassy, more rarely blue-black. Head deeply striated and carinated in front, smooth behind; palpi and antennæ black, basal joints of the latter red beneath. Thorax broadest in front with the anterior margin produced in the middle so as to form a small projecting point or angle, the sides obliquely narrowed and only slightly rounded, a little sinuated behind (Pl. I. f. 6) and curved outwards so as to form the basal angle, the basal margin slightly excavated in the middle, the disk with the dorsal furrow terminating behind in a triangular punctured depression, the base with two foveæ and all the margins strongly punctured, leaving a smooth space in the middle on each side the central furrow. Elytra oblong, much wider than the thorax, not contracted in front, but with the shoulders merely a little rounded, sides somewhat parallel, apex rounded, each elytron with one punctured stria next the suture, the punctures of which disappear before the apex, but the stria itself is carried to the extremity, then a wide longitudinal polished space, then seven other punctured striæ, the marginal one finer and more remote from the other six, all which disappear or become obsolete before the extremity, across the third and fourth striæ there is also a single deep impression; underside of the body and legs bronzed black, tibiæ sometimes testaceous externally. Length $2 \frac{1}{4}$ lines.

Upon examination of the examples of $N$. Newmanii and metallicus lent to me by Mr. Waterhouse, I refer them to this common species.

2. N. palustris : aneus nitidus; thoracis limbo punctato, lateribus rotundatis; clytris extùs striatis, striis punctatis apicem versìs evanescentibus; antennis basi, tibiisque testaceis.

Elaphrus palustris, Dufts. Faun. 2. 192.

Notiophilus palustris, Sturm, D. F. 7. 144.-Erichson, Käfer, Э.

N. tibialis, Steph. Mand. 5. 388, et Manual, p. 60.

N. brevis, brevicollis et latior, Waterhouse, Ent. Mag. 1. 206. 
This insect is apparently distinct from the preceding, though Gyllenhall and Dejean have united them. It is shorter and narrower, the head like it is deeply striated and carinated in front, but usually, though not always, finely punctured behind the eyes; the antennæ have three joints at the base entirely testaceous; the thorax is considerably shorter, with the projecting angle in the centre of the anterior margin rather more prominent, the sides are more rounded in front and more contracted behind (Pl. I. f. 7), the lateral margins and base less depressed; the elytra are shorter and very distinctly narrowed in front and the sides more rounded; the legs are bronzed black, but with the tibiæ entirely testaceous. Length 2 lines.

$N$. brevis, latior and brevicollis, Waterhouse, as well as tibialis, Stephens, are identical with this very common insect.

3. IN. rufipes : cupreo-aneus, nitidus; thoracis limbo punctato; elytris apice flavescentibus, extùs profundè punctatostriatis; antennis pedibusque ferrugineis.

Curtis, Ent. pl. 254.-Steph. Mand. 2. 190, et Manual, p. 60.

"Cupreous, shining. Head as broad as the elytra, punctured at the base, nasus and crown with deep longitudinal furrows. Thorax transverse, scarcely so broad as the head before, and narrower than the elytra behind, coarsely punctured, smooth only on the disk, in the centre of which is a deep impression as well as one at each of the posterior angles. Elytra very smooth, slightly ochreous at the tips, with a few punctures round the scutellum and a faint row down each side of the suture, six deeply punctured striæ close together towards the external margin which is smooth, between the second and third striæ before the middle is a fovea, and another near the apex ; antennæ and legs pale ferruginous, the former fuscous towards their apex." "Length $2 \frac{1}{4}$ lines.

A single example of this insect was captured by Mr. Heysham near Carlisle, many years ago, and described by Mr. Curtis, as above quoted, in his 'British Entomology', but that specimen is now lost. However, I have seen two individuals in Mr. Waterhouse's collection, which correspond acurately with the above description. The insect is the more remarkable as being the only European species of this genus with legs entirely red.

4. IN. semipunctatus : aneus, nitidus; thorace punctato disco sublavi; elytris extùs punctato-striatis striis integris; antennis basi tibiisque in medio testaceis. 
Var. a. elytris apice immaculatis.

Elaphrus semipunctatus, Fab. Mant. 1.188.-Fab. S. El. 1. 246.

Var. $\beta$. elytris apice flavescentibus.

E. biguttatus, Fab. Mant. 1. 188.-Fab. S. El. 1.247:-Gyll. Ins. Suec. 4. 399.

Notiophilus biguttatus, Dej. Spec. 2. 279; Icon. 2. 137. pl. 87. - Steph. Mand. 2. 33, et Manual, p. 60.-Heer, Faun. Helv. 42.

N. palustris, Steph. Mand. 5. 389.

N. latus et striatus, Waterhouse, Ent. Mag. 1. 209.

Var. $\gamma$. angustior, elytris subtilitèr punctato-striatis.

N. nitidus, Waterhouse, Ent. Mag. 1. 203.

N. biguttatus, Waterhouse, Fnt. Mag. 1. 210.

N. substriatus, Waterhouse, Ent. Mag. 1.211.

This species is more depressed and parallel than either of the preceding : it is very brilliant shining (usually brownish) brass above. Head finely striated in front, some of the joints at the base of the antennæ more or less testaceous. Thorax short, wide, with the usual prominent angle in the centre of the anterior margin, sides very slightly rounded immediately below the angles, then obliquely sloped towards the base, which is broader than in any of the foregoing species (Pl. I. f. 8), the disk depressed, more or less thickly but finely punctured throughout, having (in some examples) a small subpunctate or strigose space on each side the dorsal furrow about the middle, a deep fovea near each posterior angle, and all the margins more deeply punctured than the rest of the disk. Elytra broad, sides parallel, with a very finely punctured stria next the suture, which gives place at the extremity to a deep smooth stria, then a broad, highly polished, smooth space, then six entire punctured strix, the one next the polished space being flexuous near the extremity and united to the sutural one at the tip, while more distant from these six, and close to the margin, is a short one at the base, and between the third and fourth striæ is a deep impression about the middle, and a smaller one at the apex; the tibiæ are sometimes entirely testaceous, sometimes pale only in the middle. Length $2 \frac{1}{4}$ lines.

The variety of this species with the apex of the elytra immaculate appears to have been described by Fabricius first under the name semipunctatus, and he subsequently described the var. $\beta$, which is apparently the type (being far most abundant), as biguttatus, with which palustris, Steph. (not Dufts.) and latus and striatus, Waterhouse, perfectly agree. The variety $\gamma$. is smaller, narrower, and most minutely punctured, and the punctured striæ sometimes become very obsolete, or are entirely 
obliterated before the extremity. The insects described by Mr. Waterhouse under the names biguttatus, substriatus, and nitidus appear to be smaller, narrower, and more obscure individuals of this variety.

The var. $\alpha$. is uncommon.

The var. $\beta$. is generally distributed and common.

The var. $\gamma$. is of occasional occurrence; I once took it rather plentifully on the sand-hills at Deal, all the specimens being uniformly similar in form and sculpture.

5. N. 4-punctatus : aneus, nitidus; elytris profundè punctatostriatis apice flavescentibus punctis duobus impressis.

Dej. Spec. 2. 280; Icon. 2. 138. pl. 87.-Steph. Mand. 2. 190, et Manual, p. 60 .

Above brilliant shining brass. Head finely striated in front, basal joints of the antennæ testaceous. Thorax broad, with a projecting angle in the centre of the anterior margin, and with the sides obliquely sloped as in the preceding species, all the margins thickly punctured, and with a shining more distinct space on each side the dorsal furrow, a little strigose or faintly wrinkled. Elytra broader than the thorax, with the shoulders a little rounded, but not contracted in front, sides rather parallel, each elytron with a fine punctured stria next the suture terminating in a smooth stria at the tip, then a very broad highly polished longitudinal space, and then seven other punctured striæ, the two next the polished space being disposed together rather more distant from the others, and the marginal or outer one still more remote, between the third and fourth striæ are two deep impressions, and a small one at the apex; tibiæ testaceous and the extremity of the wing-cases also mure or less pale. Length $2 \frac{1}{4}$ lines.

Of rare occurrence, and probably only an uncommon variety of the preceding.

\section{Subfam. 4. Harpalides, Westwood.}

\section{Genus 18. LORICERA, Latreille.}

Mentum dente medio obtuso. Ligula apice subacuminata; paraglossis coriaceis, eam haud superantibus. Maxillæ extùs dentata. Palpi articulo ultimo subovato. Mandibulæ breves, internè basi crenulata. Labrum apice rotundatum. Tarsi antici maris articulis tribus valdè dilatatis, subtùs densè spongiosis. 
1. L. pilicornis : viridi-anea, nitida; elytris crebrè punctatostriatis, foveis tribus disci impressis; antennis basi articulis sex nodosis setis prælongis ornatis ; tibiis tarsisque testaceis.

Carabus pilicornis, Fab. Mant. 1. 200.-Fab. S. El. 1. 193.Payk. Mon. 78.

Loricera pilicornis, Gyll. Ins. Suec. 2. 45.-Sturm, D. F. 3.165. -Dej. Spec. 2. 293; Icon. 2. 155. pl.89.-Steph. Mand.1.69, et Manual, p.22.-Erichson, Käfer, 21.-Heer, Faun.Helv.43.

Above greenish brass, very shining. Head short, wide, having two rough impressions between the eyes, connected by a curved transverse stria, crown depressed; eyes globose and prominent; antennæ fuscous black, first joint long and stout with its base reddish, second, third and fourth nodose and together with the fifth and sixth set with long rigid hairs; mandibles and palpi red. Thorax subcordate, truncate before and behind, sides considerably rounded in front and suddenly contracted behind the middle, posterior angles obtuse, disk moderately convex, with a deep dorsal furrow, the base and lateral margins behind punctured, having on each side a deeply impressed fovea. Elytra oblong-ovate, distinctly margined and with the apex rather acuminated, each with twelve closely disposed striæ composed of fine regular punctures, on the third and fourth striæ are three impressed foveæ, placed one before the middle, another about the middle, and a third about midway between that and the apex; underside shining black, femora greenish brass, tibiæ and tarsi testaceous. Length 3 lines.

Common.

\section{Genus 19. PANAGFUS, Latreille.}

Mentum dente medio bifido. Ligula minuta, apice truncata; paraglossis vix ullis. Palpi articulo ultimo fortitèr securiformi, maxillares articulo secundo elongato. Mandibulæ breves, arcuate. Labrum truncatum, breve, transversum. Tarsi antici maris articulis duobus dilatatis, subtùs densè spongiosis.

1. P. crux-major : niger, pubescens; elytris punctato-striatis, rufis, basi cruce communi apiceque nigris.

Carabus crux-major, Linn. F. S. 808.-Fab. S. El. 1. 202.

Panagaus crux, Gyll. Ins. Suec. 2. 78.

P. crux-major, Sturm, D. F. 3. 170.-Dej. Spec. 2. 286 ; Icon. 2. 148. pl. 88. - Steph. Mand. 1. 71, et Manual, p. 22.Erichson, Käfer, 20.-IIeer, Faun. Helv. 43. 
Black, pubescent. Head small, with an impression on each side in front; eyes very globose and prominent; palpi large, black, pilose; antennæ black, pubescent. Thorax very globose, truncate in front, sides slightly margined, posterior angles rounded, disk very rugosely punctate, set with erect hairs, having an impression near each hinder angle. Elytra ovate, rounded at the apex, convex, deeply punctate-striated, densely pubescent, red, with a black patch surrounding the scutellum, the suture and an irregular broad transverse fascia across the middle, black, and forming a cross, the apex also with a black spot; body beneath deeply punctured, and together with the legs black and pubescent. Length $3 \frac{1}{2}$ lines.

Locally abundant in the fenny districts of Cambridgeshire and Huntingdonshire, at the roots of trees and among refuse in damp places. Also at Lawrence Waltham, Berks; Cobham, Norwood and Shooter's-hill, near London.

2. P. quadripustulatus : niger, pubescens; thorace longiore; elytris punctato-striatis, rufis, basi cruce communi limbo postico apiceque nigris.

Sturm, D. F. 3. 172.-Dej. Spec. 2. 288; Icon. 2. 150.pl. 88.Steph. Mand. 1. 70, et Manual, p. 22.-Erichson, Käfer, 21.

This species resembles the preceding, but is smaller, narrower, and otherwise sufficiently distinct. Thorax more orbicular, smaller, proportionally longer and more narrowed behind, with the basal impressions less distinctly marked. Elytra more convex, more narrowed in front and the angles more rounded, the rufous colour generally of a deeper shade, the posterior red spot is always round (and not angular like the corresponding one in crux-major), and does not touch the outer margin, so that the entire limb is narrowly black. Length 3 lines.

It is apparently a less common species than the preceding. The first British specimen was taken in May 1812, in a gravelpit in Coombe Wood, and the species has frequently been found since in the same locality. It has usually been considered an insect of solitary habits, but has on two occasions been taken in profusion; at Hertford under stones and clods of earth, and at Fulbourne near Cambridge, from tussocks of coarse grass. I have taken it from moss in a gravel-pit at Fort Monkton, Hants; near Sandown, Isle of Wight ; and on the sand-hills at Deal, in May and September.

\section{Genus 20. BADISTER, Clairville.}

Mentum dente medio nullo. Ligula brevis, apice truncata; paraglossis membranaceis, elongatis, eam longè superantibus. Palpi 
articulo ultimo subovato. Mandibulæ breves, obtusa. Labrum bilobum. Tarsi antici maris articulis tribus valdè dilatatis, subtùs densè spongiosis.

1. B. bipustulatus : capite nigro, thorace subcordato pedibus elytrisque rufo-testaceis, his posticè nigris, suturâ margine summo maculdque communi rufo-testaceis.

Carabus bipustulatus, Fab. S. El. 1. 203.

Amblychus bipustulatus, Gyll. Ins. Suec. 2. 74.

Badister bipustulatus, Sturm, D. F. 3. 186.-Dej. Spec. 2.406; Icon. 223. pl. 101.-Steph. Mand. 1.72, et Manual, p. 22.Erichson, Käfer, 23.-Heer, Faun. Helv. 49.

B. microcephalus, Steph. Mand. 5. 373, et Manual, p. 22.

Var. $\beta$. capite paulo majore, thorace breviore, scutello rufescente.

B. lacertosus, Sturm, D. F. 3. 188.-Steph. Mand. 5. 374, et Manual, p. 22.

Head black, in some examples very small, in others large, but always narrower than in the next species, basal joint of the antennæ testaceous. Thorax testaceous red, subcordate, sides rounded and narrowed behind and the posterior angles rather rotundate (Pl. I. f. 16), the dorsal furrow very fine, the base furnished with two foveæ. Elytra oblong, wider than the thorax, simply striated, testaceous red in front with the suture and margins paler, having a broad cyaneous patch behind including a common reddish testaceous spot before the apex varying considerably in shape from round to oblong and occasionally obsolete; scutellum usually black, but sometimes pitchy red; breast wholly black, legs testaceous. Length $2 \frac{1}{2}-3$ lines.

Common.

2. B. unipustulatus : capite thoracis latitudine nigro, thorace breviore posticè magis angustato, pectoris scapulis pedibus elytrisque rufo-testaceis, his posticè nigris, suturâ margine summo maculáque communi rufo-testaceis.

Bonelli, Obs. Ent. Mem. de l'Acad. Imp. Turin, 1811-1812, p. 443.-Erichson, Käfer, 22.-Heer, Faun. Helv. 49.

B. cephalotes, Dej. Spec. 2.406; Icon. 2. 223. pl. 100.-Curtis, Ent. pl. 139.--Steph. Mand. 1. 72, et Manual, p. 22.

B. suturalis, Steph. Mand. 1. 73, et Manual, p. 22.

Larger than bipustulatus. Head broader, about as wide as the thorax, very much depressed in front, the basal joint of the antennæ testaceous only at its base. Thorax considerably shorter (Pl. I. f. 17), wide in front, and much narrower behind than in the allied species, with the posterior angles more rotundate, the dorsal 
furrow more deeply impressed, and the basal foveæ larger and more strongly marked; scutellum red. Elytra more deeply striated, testaceous red over a more considerable space in front, with the suture and margins paler, and an oblong blue-black or cyaneous patch behind the middle enclosing a semilunar or oblong or roundish testaceous red spot common to both wing-cases before the apex; breast black with a pale testaceous spot on the scapulars; legs also testaceous. Length 3 lines.

Local. Newark; Battersea fields and Hammersmith marshes at the roots of willows; "in profusion at Winterbourne Stoke, Wilts, in March and April," Rev. G. T. Rudd.

\section{(Trimorphus, Stephens.)}

3. B. peltatus : nigro-aneus, micans, thoracis elytrorumque margine summo pedibusque brunneo-testaceis. (Pl. I. f. C.)

Carabus peltatus, Panz. Faun. 37.-Dufts. Faun. 2. 147. Amblychus peltatus, Gyll. Ins. Suec. 2. 76 .

Badister peltatus, Sturm, D. F. 3. 189.-Dej. Spec. 2. 408; Icon. 2. 226. pl. 101.-Erichson, Käfer, 24.-Heer, Faun. Helv. 49.

Trimorphus Erro, Newman, Ent. Mag. 5. 489.-Steph. Manual, p. 23.

This species, which is about the size of a smallest bipustulatus, is obscure brassy black, very shining, especially on the surface of the elytra ; margins of the thorax and elytra narrowly edged with brownish testaceous. Head black, smooth and shining; antennæ slender, brownish black, base of the first joint paler. Thorax subquadrate, sides rounded below the anterior angles, thence narrowed behind, posterior angles obtuse, dorsal furrow deep, base with two large impresised foveæ. Elytra wider than the thorax, oblong, slightly convex, distinctly striated, the striæ impunctate with the exccption of two small impressions on the second; the surface suffused with bright cyaneous reflections in certain lights ; underside of the body brownish black, legs dusky testaceous. Length $2 \frac{1}{4}$ lines.

Three examples of this rare insect are ascertained to have been captured in England; one by Mr. Ingall near London, which is the insect described by Mr. Newman in the 'Entomological Magazine' under the name Trimorphus Erro; two others have been obtained by Mr. S. Stephens near Hammersmith.

4. B. humeralis : nigro-obscurus, subnitidus; thoracis margine elytrorum maculá humerali margine pedibusque flavo-testaceis.

Bonelli, Obs. Ent. Mem. de l'Acad. Imp. Turin, 1811-1812, 
p. 443.-Dej. Spec. 2. 410 ; Icon. 2.227.pl. 101.-Erichson, Käfer, 23.-Heer, Faun. Helv. 49.

B. sodalis, Sturm, D. F. 3. 191.

Carabus dorsiger, Dufts. Faun. 2. 151.

Trimorphus scapularis, Steph. Mand. 1. 180.

T. confinis, Steph. Mand. 1. 181, et Manual, p. 23.

Obscure black, with a cyaneous reflection on the elytra. Head round, smooth, depressed in front, mouth yellow, base of the first joint of the antennæ testaceous, its apex together with the whole of the second, third and fourth joints brownish, the rest reddish, more or less obscure. Thorax obcordate, sides obliquely sloped and narrowed behind, margins pale, delicately reflexed and elevated towards the hinder angles which are rounded, disk transversely wrinkled, having a deep central longitudinal furrow and two large and very deep fover at the base; scutellum large, triangular and black. Elytra oblong-ovate, humeral angles rounded, sides very little rounded and only slightly widest behind, disk striated, the second stria with two impressions, and a series of deeper punctures on the margins, the latter together with the suture behind and a broad subquadrate spot widest behind on the shoulders testaceous yellow; underside of the body brownish black; legs pale yellow. Length 2 lines.

This species is local, but widely distributed. "Carlisle in February and March," Mr. Heysham. "Earl's Court, Brompton," Mr. Waterhouse. "Battersea fields; Darenth; in Norfolk; Loch Awe, Scotland," Mr. Stephens. "Castle Wood, Morpeth," Mr. Scott. I have captured it near Hastings; and for several years procured it annually in the spring from a copse near Shanklin, Isle of Wight.

\section{Genus 21. LICINUS, Latreille.}

Mentum dente medio nullo. Ligula brevis, apice truncata ; paraglossis membranaceis, apice rotundatis, ei aqualibus. Palpi articulo ultimo securiformi. Mandibulæ breves, obtusa. Labrum apice levitèr emarginatum. Tarsi antici maris articulis duobus valdè dilatatis, subtùs densè spongiosis.

1. I. depressus : ater, thorace lateribus subrotundato, elytris oblongo-ovatis, punctato-striatis, interstitiis planis, undique punctatissimis.

Carabus depressus, Payk. Faun. 1. 110.

Licinus depressus, Gyll. Ins. Suec. 2. 73.-Dej. Spec. 2. 401; Icon. 2. 217. pl. 99.-Curtis, Ent. pl. 75.-Steph. Mand. 1. 73, et Manual, p. 23.-Erichson, Käfer, 22.-Heer, Faun. Helv. 47.

Carabus cassidens, Ill. Käfer, 1. 159. 
Entirely deep shining black, the elytra of the $q$ duller black. Head small, round, much depressed in front, very finely punctured, but a little smooth at the nape. Thorax widest in front with the angles a little acuminated, sides rounded and gradually narrowed towards the hinder angles which are rounded, disk rather convex, densely punctured, the dorsal furrow abbreviated, the base without foveæ, but the lateral margins elevated especially at the hinder angles. Elytra oblong-ovate, rounded at the shoulders, apex obliquely truncate, moderately convex, finely striated, the striæ obsoletely punctured, interstices flat and thickly punctured; underside of the thorax and breast punctate; cilia and claws red. Length $4 \frac{1}{2}$ lines.

This species is found in chalky districts; near, Canterbury, Dover, Box Hill, \&c. in the autumn.

2. I. Silphoides : ater, thorace transverso lateribus rotundato, punctato, in medio sublavigato; elytris ovatis, punctatostriatis, interstitiis subelevatis profundè punctatis, tribus magìs elevatis.

Carabus Silphoides, Fab. S. El. 1. 190.

Licinus Silphoides, Sturm, D. F. 3. 177.-Dej. Spec. 2. 394 ;

Icon. 2. 210. pl. 98.-Steph. Mand. 1. 73, et Manual, p. 23.

Deep black. Head minutely punctured, depressed in front, with an elevated ridge on each side between the antennæ connected by a curved transverse fold in front; palpi and two joints at the base of the antennæ pitchy black, the rest fuscous. Thorax transverse, very short and broad, anterior angles produced, sides regularly rounded, widest about the middle, margins elevated especially at the base, hinder angles rotundate, disk strongly punctured and wrinkled but a little smooth in the centre, with an abbreviated dorsal furrow and a broad obsolete fovea on each side at the base. Elytra ovate, broad, humeral angles rounded, sinuated before the apex, which latter is much produced, finely striated, the striæ deeply, regularly and remotely punctured, the interstices sparingly but deeply punctured and slightly elevated, the third, fifth and seventh more elevated, so as to present the appearance of three distinct raised lines; body beneath minutely, sides of the breast coarsely punctured; cilia and claws red. Length $5 \frac{1}{2}-6 \frac{1}{2}$ lines.

In profusion on the south-east side of Box Hill in autumn. Found also in the Isle of Portland; at Dover, \&c. and in other chalky districts.

\section{Genus 22. OÖDES, Bonelli.}

Mentum dente medio integro. Ligula apice libera dilatataque; paraglossis membranaceis. Palpi articulo ultimo cylindrico, 
apice truncato. Mandibulæ rectiuscula, acuta. Labrum apice truncatum. Tarsi antici maris articulis tribus dilatatis, singulis subquadratis, subtùs densè spongiosis.

1. O. Helopioides : oblongo-ovatus, ater, elytris subtilitèr punctato-striatis.

Carabus Helopioides, Fab. Ent. S. 1. 155.-Fab. S. El. 1. 196. Harpalus Helopioides, Gyll. Ins. Suec. 2. 135.

Oödes Helopoides, Sturm, D. F. 6. 66.-Dej. Spec. 2. 378; Icon. 2. 201 . pl. 97. - Steph. Mand. 1. 125, et Manual, p. 35. -Erichson, Käfer, 96.-Heer, Faun. Helv. 47.

Deep black. Head and thorax smooth and impunctate, the latter narrowed in front, then gradually widening till it becomes broad behind the middle, the posterior angles produced, the disk with a faint dorsal furrow and the base destitute of foveæ. Elytra as broad as the thorax, oblong, the sides straight nearly to the extremity and the apex broadly rounded in some examples but slightly sinuated in others, convex, striated, the striæ finely punctulated, with two minute impressions between the second and third from the suture, and a series on the exterior margin; body beneath thickly punctured on the sides; legs black, tarsi pitchy. Length $4 \frac{1}{2}$ lines.

The peculiarity of form in the species which represents this genus must always sufficiently distinguish it, especially its broad thorax equalling the elytra in width, and the oblong, convex and parallel form of the entire insect.

-It is not a very abundant species, or at any rate is rather local. It is found in marshy places, in the Cambridgeshire fens, more plentifully near Whittlesea Mere and at Herringstone near Dorchester; and according to Stephens in Hackney marshes; Battersea fields; Abbots Ann, Hants ; Amesbury, Wilts, \&c.

\section{Genus 23. CHIAEINIUS, Bonelli.}

Mentum dente medio bifido. Ligula cornea, apice libera dilatataque; paraglossis membranaceis apice liberis, eam vix superantibus. Palpi articulo ultimo cylindrico, apice truncato. Mandibulæ acuta, basi crenulate. Labrum apice truncatum vel obsoletè sinuatum. Tarsi antici maris articulis tribus dilatatis, singulis subquadratis, subtùs densè spongiosis.

1. C. sulcicollis: nigro-obscurus, pubescens; thorace posticè trisulcato, punctatissimo; elytris obsoletè punctato-striatis, interstitiis rugoso-granulatis; antennis pedibusque nigris.

Carabus sulcicollis ơ, Payk. Faun. 1. 153.

Harpalus sulcicollis ô, Gyll. Ins. Suec. 2. 130. 
Chlanius sulcicollis, Sturm, D. F. 5. 144.-Dej. Spec. 2. 356 ; Icon. 2. 182. pl. 94.-Curtis, Ent. pl. 83.-Steph. Mand. 1. 77, et Manual, p. 24.-Erichson, Käfer, 97.-Heer, Faun. Helv. 46.

Head black, obsoletely wrinkled, with an oblong fovea on each side in front; mandibles pitchy, palpi and antennæ black, the upper joints of the latter fusco-pubescent. Thorax fuscous black, wide especially behind, rather narrowed in front and rounded at the angles, disk very much punctured, the punctures more sparingly distributed and the surface more glabrous in front, closely and finely granulated and scabrous behind, and clothed with a brownish pubescence, the base with three abbreviated longitudinal furrows and exterior to these an oblong rugose fovea near each angle; scutellum smooth. Elytra very wide, ovate, rather convex, fuscous black, clothed with a brownish pubescence, obsoletely punctate-striated, interstices closely granulated and rugose, and presenting a finely shagreened appearance; underside of the body and legs black. Length 6 lines.

The claim of this rare species to admission into our indigenous fauna is very meagre, resting upon a solitary example in the cabinet of J. Curtis, Esq. It was picked up (dead) on the coast near Covehithe, Suffolk, by that gentleman's brother.

2. C. holosericeus : capite sublavi obscure aneo; thorace subquadrato punctato-ruguloso; elytris striatis interstitiis rugoso-granulatis nigro obscuris pubescentibus; antennis pedibusque nigris.

Carabus holosericeus, Fab. Mant. 1. 199 (1787).-Fab. S. El. 1. 193.-Payk. Mon. 110 (1790).-Payk. Faun. 1. 153.

Harpalus holosericeus, Gyll. Ins. Suec. 2. 112.

Chlanius holosericeus, Sturm, D. F. 5. 134.-Dej. Spec. 2. 355; Icon. 2. 181. pl. 93. -Steph. Mand. 1. 177, et Manual, p. 24. -Erichson, Käfer, 98.-Heer, Faun. Helv. 46.

Rather larger and broader than nigricornis. Head obscurely bronzed or coppéry, sometimes a little greenish, smooth ; antennæ black. Thorax subquadrate, the width rather greater than the length, sides very moderately rounded so that the base is as wide as the anterior margin, hinder angles obtuse, obscure dusky black, sometimes faintly coppery, very densely clothed with a yellowish brown pubescence, rugosely punctate and presenting a shagreened appearance, base with an obsolete fovea in each angle. Elytra also obscure brownish black, and like the thorax clothed with a very dense yellowish brown pubescence, oblong-ovate, striated, the striæ very fincly punctate, interstices thickly rugose 
and granulated; underside of the body and the legs black. Length $5_{\frac{1}{4}}^{1}$ lines.

This insect appears to be extremely rare in this country. $\mathrm{Mr}$. Stephens quotes Fen Ditton, Berks, as one of its localities, and further states that Mr. Weaver captured several specimens near Whittlesea Mere in August 1826. It is said to have been found also in Norfolk by Mr. Skrimshire. Three examples were taken more recently by Mr. Grimston at Hornsey on the Yorkshire coast during a flood; and a single individual by Mr. Haliday near Athy in Ireland.

3. C. nigricornis : viridis, pubescens; capite sublavi thoraceque punctatissimoviridi-cupreis, hoc subquadrato, angulis posticis obtusis; elytris striatis, interstitiis subtiliter granulatis; antennarum articulo primo pedibusque nigro-piceis.

Carabus nigricornis, Fab. Mant. 1.202 (1787).-Fab. S. El. 1. 198.-Payk. Mon. 112 (1790).-Payk. Faun. 1. 154.

Harpalus nigricornis, Gyll. Ins. Suec. 2. 113.

Chlanius nigricornis (var. b), Sturm, D. F. 5. 135.-Dej. Spec. 2. 351 ; Icon. 2. 177. pl. 92.-Steph. Mand. 1. 177, et Manual, p. 24.-Erichson, Käfer, 99.-Heer, Faun. Helv. 46.

Var. $\beta$. antennarum articulo primo pedibusque rufis.

C. melanocornis, Dej. Spec. 2. 350; Icon. 2. 175.pl. 92.-Steph. Mand. 1. 78, et Manual, p. 24.-Heer, Faun. Helv. 45.

C. fulgidus, Steph. Mand. 1. 98, et Manual, p. 24.

Above rich green, head and thorax with a reddish coppery tinge. Head triangular, convex, rather smooth, having an oblong fovea on each side between the antennæ connected by a transverse line; mouth, palpi and basal joint of the antennæ pitchy black. Thorax subquadrate, short, the width being somewhat greater than the length, sides regularly and very moderately rounded, base truncate, hinder angles obtuse, dorsal furrow abbreviated before and behind, disk thickly punctured, base with an oblong impression on each side. Elytra broad, ovate, striated, interstices finely granulated; underside dull black, pubescent, sides of the thorax purplish green, thickly but not coarsely punctured and transversely wrinkled; legs pitchy black. Length 5 lines.

The variety melanocornis differs only in having the mouth, palpi, basal joint of the antennæ and the legs red. C. fulgidus, Steph., is an immature individual of this variety; and I may here mention that C. xanthopus, Steph., is represented, according to Dr. Schaum, by a North American insect.

This species is found pretty commonly in fens, marshes, and on the banks of rivers. It has been taken by Mr. Haliday at Holywood in Ireland. 
4. C. agrorum : viridis, thorace elytrisque pubescentibus subtilissimè granulatis; elytris striatis, margine antennarum basi pedibusque flavis.

Carabus agrorum, Oliv. Ent. 3. 35.

Chlrenius agromem, Sturm, D. F. 5. 129.-Dej. Spec. 2. 313;

Icon. 2. 169. pl. 91.-Steph. Mand. 1. 79, et Manual, p. 24. -Heer, Faun. Helv. 45.

Above beautiful light green. Head finely and delicately rugose, having a deeply impressed pit on each side in front near the base of the antennæ; three joints at the base of the latter, together with the palpi testaceous, the rest of the antennæ pale dull brown and pubescent, the mandibles pitchy, the labrum testaceous. Thorax narrowest in front, the sides a little rounded below the angles, then from about the middle to the base straight, the posterior angles obtuse, disk with a slender dorsal furrow, and on each side at the base an oblong impression, the whole surface beautifully shagreened and adorned with a golden pile; scutellum sometimes yellowish. Elytra oblong, not so much narrowed in front as in nigricornis, rather obsoletely striated, the interstices finely granulated, the surface thickly clothed with a golden pubescence and the whole exterior margin testaceous yellow; beneath the thorax and breast are greenish black, the abdomen dusky and the whole surface punctured, legs testaceous. Length $5 \frac{1}{\Omega}$ lines.

The claim of this very conspicuous insect to admission into our indigenous fauna rests upon very few examples at present, and some of these are very dubious. Stephens has informed us that it was captured by Dr. Leach, near Plymouth, in the spring of 1816, and that it has been found near Bristol. The Rev. H. Clark has a specimen in his collection, which was taken at Matlock.

5. C. vestitus : viridis, pubescens; thorace subcordato, punctato, angulis posticis rectis; elytris striatis, interstitiis subtiliter granulatis, margine ante apicem dilatato antennis pedibusque flavo-testaceis.

Carabus vestitus, Payk. Mon. 71 (1790).-Fab. Ent. S. 1.158 (1792).-Fab. S. El. 1. 200.

Harpalus vestitus, Gyll. Ins. Suec. 2. 84.

Chlanius vestitus, Sturm, D. F. 5. 130.-Dej. Spec. 2. 322 ; Icon. 2. 172. pl. 91.-Steph. Mand. 1. 79, et Manual, p. 24 . -Erichson, Käfer, 100.-Heer, Faun. Helv. 45.

Head purplish green, with two foveæ connected by a transverse line in front; mouth, palpi and antennæ testaceous. Thorax 
subcordate, sides rounded in front from below the anterior angles to behind the middle, then straight so as to form with the base a right angle, green, pubescent, rather depressed, coarsely punctured, the dorsal furrow interrupted in front and terminating in a depression, base with two oblong impressions. Elytra twice the width of the thorax, ovate, dilated behind the middle, dull green, densely pubescent, the lateral margins testaceous yellow dilated and denticulated before the extremity, striated, the interstices finely granulated; underside of the body dull black, punctured and pubescent; legs testaceous yellow. Length $4 \frac{1}{2}$ lines.

Abundant beneath stones near streams, and in swampy places near London; on the southern coasts, as well as in many other parts of England and Ireland.

\section{Genus 24. CALLISTUS, Latreille.}

Mentum dente medio integro, lato, obtuso. Ligula apice dilatata, obtusa, paraglossis membranaceis longior. Palpi articulo ultimo subovato, apice acuminato. Mandibulæ breves, acuta. Labrum apice truncatum. Tarsi antici maris articulis tribus dilatatis, subtùs densè spongiosis.

1. C. Iunatus : capite nigro cyaneo, thorace rufo, elytris flavotestaceis nigro-maculatis.

Carabus lunatus, Fab. Ent. S. 1. 163.-Fab. S. El. 1. 205.

Anchomenus lunatus, Sturm, D. F. 5. 176.

Callistus lunatus, Dej. Spec. 2. 296 ; Icon. 2. 158. pl. 89.-

Curtis, Ent. pl. 180._Steph. Mand. 1.81, et Manual, p. 24. -Heer, Faun. Helv. 44.

Head large, oblong, with a cyaneous (or sometimes greenish) tinge, strongly punctured; antennæ dusky, with two joints at the base testaceous. Thorax testaceous red, cordate, sides rounded in front and widest in the middle, very much contracted behind, posterior angles acute, disk convex, very finely and closely punctured, with a slender dorsal furrow abbreviated before and behind, and an obsolete fovea near each basal angle. Elytra ovate, shoulders rounded and narrowed, sides a little sinuated, widest behind the middle, disk somewhat convex, very finely punctate-striated and with the interstices closely and minutely punctured and pubescent, testaceous yellow, with a small rounded spot on the humeral angles, a broad transverse fascia about the middle not reaching the suture, and another before the apex extending across the suture and connected externally with the central fascia black; underside blue-black, 
punctured and pubescent, legs yellow, apex of femora and tarsi brownish black. Length 3 lines.

Very local; but taken occasionally near Folkstone, Dover, Canterbury, Kingstone, and other chalky districts of Kent.

\section{Genus 25. POGONUS, Dejean.}

Mentum profundè emarginatum, dente medio bifido. Palpi articulo ultimo oblongo-ovato, apice truncato. Mandibulæ basi intùs denticulata, subarcuate, acuta. Labrum breve, transversum, emarginatum. Tarsi antici maris articulis duobus dilatatis.

1. P. luridipennis : viridi-aneus; thorace subtransverso, posticè coarctato, angulis posticis subrectis ; elytris ochraceis, aneo micantibus, subparallelis, striato-punctatis, punctis tribus impressis; ore antennis pedibusque rufo-testaceis.

Harpalus luridipennis, Germ. Ahrens, Faun. Eur. 7. 2. (1812, \&c.).

Pogonus luridipennis, Dej. Spec. 3. 9; Icon. 2. 244. pl. 103.

P. Burrellii, Curtis, Ent. pl. 47.-Steph. Mand. 1. 106, et Manual, p. 31.

Head and thorax brassy green with coppery reflections, the former with an oblong fovea on each side and transversely wrinkled on the crown, mouth, palpi and antennæ reddish teistaceous. Thorax transverse, short, sides rounded in front from below the angles to behind the middle, then straight, the posterior margin being sloped towards the hinder angles so as to render them not quite rectangular, disk convex, strongly wrinkled, having a deep dorsal furrow which is entire but intersected in front by a slightly rugose transverse impression, the base depressed punctured and rugose, having a broad not very deep punctured fovea near each angle, exterior to which is an elevated line running into the angle itself. Elytra ochreous with a bronzed cloud on the disk, broad, a little rounded below the angles, punctate-striated, the striæ appearing rather greenish, and most deeply impressed in the centre of the disk, less deep on the sides and at the apex, the second stria with a deeper puncture before the extremity, and the third with two others placed one about the middle and another before the middle; underside black, legs reddish testaceous. Length $3 \frac{1}{2}$ lines.

This conspicuous and well-marked species was first discovered in this country near Salthouse on the Norfolk coast by the late Rev. J. Burrell, after whom Mr. Curtis named it, but it had previously been described in Ahrens' European Fauna under the 
name luridipennis. It has also been taken at Lymington Salterns ; near Sandwich; and in profusion on the muddy banks of the Thames in the Isle of Sheppey.

2. P. chalceus : aneus; thorace subquadrato, posticè subcoarctato, angulis posticis subrectis ; elytris oblongis, subparallelis, striato-punctatis, punctis tribus impressis, striis externis obsoletis; femoribus rufo-piceis, tibiis tarsisque rufescentibus.

Carabus chalceus, Marsham, Ent. 460.

Pogonus chalceus, Steph. Mand. 1. 107, et Manual, p. 31.

$\boldsymbol{P}$. halophilus, Germ. Ahrens, Faun. Eur. 10. 1.-Dej. Spec. 3. 13 ; Icon. 2. 249. pl. 104.

P. littoralis, Steph. Mand. 5. 376, et Manual, p. 31.

Shining brassy, sometimes bluish or greenish brass. Head smooth, with a deep oblong fovea on each side between the antennæ, the latter fuscous black with their apex paler. Thorax subquadrate, the breadth being rather greater than the length, sides rounded, but not so much as in the preceding species, nor so much or so suddenly contracted behind, posterior angles very nearly right angles, disk convex, dorsal line slender and intersected in front by a triangular punctured impression, base depressed, punctured, having a punctured fovea on each side, and exterior to that a minute elevated line running into the angle. Elytra oblong, sides very slightly rounded, convex, punctate-striated, the striæ much finer and the punctures wanting behind the middle, and both entirely obsolete on the sides, the third stria has a deeper impression before the middle and another about the middle, and the second has a less distinct one nearer the extremity; underside black, legs red, femora sometimes pitchy red. Length 3 lines.

$P$. littoralis, Steph., does not differ from the present species.

Common in salt-marshes and estuaries, and on the banks of tidal rivers.

3. P. littoralis : viridi-æneus; thorace latiore subquadrato, anticè posticèque subcoarctato, angulis posticis subrectis; elytris oblongis, subparallelis, fortitèr striato-punctatis, punctis tribus impressis, striis externis obsoletis; femoribus rufo-piceis, tibiis tarsisque rufescentibus.

Carabus littoralis, Dufts. Faun. 2. 183.

Platysma littoralis, Sturm, D. F. 5. 67.

Pogonus littoralis, Dej. Spec. 3. 11; Icon. 2. 280. pl. 104.

P. aruginosus, Steph. Mand. 1. 107, et Manual, p. 31. 
Larger than chalceus and uniformly brassy green. Head wide with an oblong smooth impression on each side, the space between them on the crown being broader and smoother than in the former species, the antennæ fuscous black, the apical joints a little stouter. Thorax subquadrate, more narrowed in front, but broader and more dilated and rounded in the middle on the sides and a little narrowed behind, the posterior angles not quite rectangular, disk very much wrinkled, dorsal furrow slender and intersected in front by a curved punctured or rugose impression, base depressed, the entire space between the basal foveæ more thickly and strongly punctured, the fover themselves not quite so deep but broader and very much punctured, having also exterior to them an elevated line running into the angle as in the foregoing species. Elytra much broader, subparallel, strongly striate-punctate in front, the striæ more slender and the punctures absent behind the middle and both altogether obsolete on the sides as in the allied species, having also three deeper impressions similarly placed; underside black, legs rusty red, the femora darkest. Length $3 \frac{1}{4}$ lines.

This insect is very closely allied to the preceding, but is larger and longer, rather more convex, and usually entirely brassy green above. The thorax is distinctly narrower in front and behind and appears therefure more rounded at the sides; the elytra are wider, more deeply striated, and the striæ more strongly punctured in front. Dejean points out other particulars by which it is to be distinguished, but little reliance is to be placed upon them; its general habit or appearance, as above indicated, will amply serve to recognize it after a very little practice.

It may be taken in great profusion in Lymington Salterns under clods of clay, unassociated with chalceus, though the latter is found also in other parts of the same Salterns; on the Lincolnshire coast I have taken them in company; but at Deal, Whitstable, Gravesend, and in the Isle of Wight, \&c., chalceus is found without any examples of littoralis associated with it. $P$. aruginosus, Steph., is an immature individual of this species.

\section{Genus 26. PATroBUS, Dejean.}

Mentum dente medio bifido. Ligula cornea, apice rotundata ; paraglossis apice rotundatis. Palpi articulo ultimo subcylindrico, apice truncato. Mandibulæ subarcuata, acutiuscula. Labrum transversum, breve, truncatum. Tarsi antici maris articulis duobus dilatatis, subobcordatis, subtìs biseriatìm pectinatosetosis. 
1. P. excavatus : apterus, nigro-piceus, nitidus; thorace cordato, posticè utrinque profundè foveolato punctulatoque; elytris oblongo-ovatis, punctato-striatis, punctis tribus impressis ; pedibus rufescentibus.

Carabus excavatus, Payk. Mon. 38.-Panz. Faun. 32.-Erichson, Käfer, 119.-Heer, Faun. Helv. 51.

Harpalus rufipes, Gyll. Ins. Suec. 2. 97.

Platysma rufipes, Sturm, D. F. 5. 56.

Patrobus rufipes, Dej. Spec. 3. 28 ; Icon. 2. 256. pl. 106.Steph. Mand. 1. 119, et Manual, p. 34.

Pitchy black, sometimes reddish pitchy. Head convex, smooth, with an oblong fovea on each side in front between the antennæ and a transverse punctured impression behind the eyes, antennæ pitchy red. Thorax elongate, heart-shaped, narrowed behind, posterior angles acute and elevated, rather convex, very shining, with a deep longitudinal dorsal furrow, met in front by a row of deep punctures, base with two deeply impressed punctured foveæ. Elytra oblong-ovate, humeral angles much rounded and rather narrow, sides widest behind, disk very shining, punctate-striated, the striæ rather obsolete at the sides and apex, between the second and third from the suture three deeper impressions; legs rusty red with the thighs darker. Length $3 \frac{1}{2}-4$ lines.

Paykull's and Panzer's name excavatus must be adopted for this species; C. rufipes of Fabricius is identical with Calathus fuscus.

This species is found in profusion on the Welsh mountains, in the north of England, and in Scotland and Ireland. I have taken it abundantly also in damp woods in Kent and on the shores of the Thames below Gravesend.

2. P. septentrionis : alatus, nigro-piceus; thorace subcordato, posticè utrinque foveolato; elytris oblongo-ovatis, subtilitèr punctato-striatis, punctis tribus impressis; pedibus piceis.

Dej. Spec. 3. 29 ; Icon. 2. 266. pl. 106.-Heer, Faun. Helv. 51. P. alpinus, Curtis, Ent.pl.192.-Steph. Mand.1.120, et Manual, p. 34 .

Harpalus rufipes, var. c., Gyll. Ins. Suec. 2. 97.

This species is larger and longer than excavatus and is further distinguished by its ample wings. It is pitchy black with the mouth and palpi red, the antennæ pitchy rufous. Thorax shorter, less cordate, wider at the base, with the latter not punctured but furnished with two large fover, the anterior margin also is more sparingly punctured, disk depressed and much wrinkled transversely on each side the dorsal furrow. Elytra more elongate, 
broader, smoother and flatter, the punctured striæ much finer and almost obsolete at the apex and on the sides, having three equidistant larger impressions between the third and fourth striæ. Length $4 \frac{1}{2}$ lines.

Sparingly distributed on the Scotch mountains.

\section{Genus 27. PRISTONYCHUS, Dejean.}

Mentum dente medio emarginato. Ligula apice truncata; paraglossis linearibus, eam paulìm superantibus. Palpi articulo ultimo cylindrico. Mandibulæ rectiuscula, acuta. Labrum quadratum, apice leviter emarginatum. Tarsi antici maris articulis tribus dilatatis, subtìs biseriatìm pectinato-setosis, unguiculi intùs basi subtilitèr serrati.

1. P. terricola : apterus, nigro-piceus; thorace subcordato, posticè utrinque impresso; elytris obscurè cyaneis, striatis, striis subtilissimè punctulatis; antennis pedibusque fusco-piceis.

Carabus terricola, Herbst, Archiv, 164 (1794).-IIl. Käfer, 1. 184 (1798).

Pristonychus terricola, Dej. Spec. 3.45; Icon. 2.275. pl. 107.Steph. Mand. 1. 85, et Manual, p. 25.-Heer, Faun. Helv. 53. Carabus subcyaneus, Ill. Mag. 1.57 (1801).

Harpalus subcyaneus, Gyll. Ins. Suec. 2. 91.

Sphodrus subcyaneus, Sturm, D. F. 5. 151.

Pristonychus subcyaneus, Erichson, Käfer, 105.

Beneath pitchy black, above shining black; elytra blue-black or cyaneous. Head oblong with an impression on each side behind the antennæ, connected by a transverse raised line in front; antennæ and palpi pitchy. Thorax cordate, anterior angles produced, sides regularly and evenly rounded till behind the middle, then narrowed towards the posterior angles, which are acute and prominent, disk transversely wrinkled, with a faint dorsal line touching the base, but terminated in front by a triangular depression, base with two fover ending above in a curved stria. Elytra ovate, regularly striated, the striæ finely punctured, margins with a series of deeper impressions; legs pitchy black. Length 7 lines.

Common.

\section{Genus 28. SPHODRUS, Clairville.}

Mentum dente medio brevi, emarginato. Ligula lata, apice truncata ; paraglossis linearibus, eam superantibus. Palpi articulo 
ultimo cylindrico. Mandibulæ longiuscula, basi intùs denticulate, apice acuminate. Labrum truncatum. Tarsi antici maris articulis dilatatis, subtìs biseriatim pectinato-setosis.

1. S.leucophthalmus: alatus, niger opacus, subdepressus; thorace subcordato; elytris oblongo-ovatis, subtilitèr punctatostriatis.

Carabus leucophthalmus, Linn. F. S. 784.-Marsham, Ent. 431. Harpalus leucophthalmus, Gyll. Ins. Suec. 2. 80.

Sphodrus leucophthalmus, Steph. Mand. 1.84, et Manual, p. 25. -Erichson, Käfer, 106.-Heer, Faun. Helv. 52.

Carabus planus, Fab. S. El. 1. 179.

Sphodrus planus, Sturm, D. F. 5. 149.-Dej. Spec. 3. 88; Icon. 2. 327. pl. 114.

Head oblong, smooth, with an impression on each side between the antennæ. Thorax narrow, heart-shaped, anterior angles obtusely prominent, sides rounded and widest about the middle, narrowed behind, posterior angles acute and prominent, very rugose especially on the sides and at the base, which has two oblong depressed striæ, the central line very faint and intersected before and behind by a transverse stria. Elytra oblong, opake black, sides rather parallel, faintly punctate-striated, the second stria from the margin with a series of larger impressions. Length 10-12 lines.

In cellars and outhouses, generally distributed; but very rare in Ireland.

\section{Genus 29. CALATHHU, Bonelli.}

Mentum dente medio bifido. Ligula apice rotundata; paraglossis ei aqualibus. Palpi articulo ultimo cylindrico. Mandibulæ breves, basi obsoletè crenulata, acuta. Labrum quadratum, apice truncatum. Tarsi antici maris articulis tribus dilatatis, subtùs biseriatìm pectinato-setosis, unguiculi serrati.

1. C. piceus : apterus, nigro-piceus; thorace quadrato, anticè posticèque subangustato, basi utrinque foveolato, angulis posticis rotundatis; elytris ovatis subtilitèr striatis, punctis quinque impressis; pedibus rufo-piceis.

Carabus piceus, Marsham, Ent. 444.

Calathus piceus, Steph. Mand. 1. 98, et Manual, p. 28.

C. rotundicollis, Dej. Spec. 3. 75 ; Icon. 2. 312. pl. 112.

Amphyginus piceus, Haliday, Ent. 175.

Wingless, pitchy black. Head very smooth and convex behind and with a small fovea on each side between the antennæ and 
a transverse impression in front, enclosing an elevated space between them; mandibles pitchy, palpi and antennæ testaceous red. Thorax quadrate, narrowed in front, sides regularly rounded and widest about the middle, obliquely narrowed behind, the margins finely reflexed, posterior angles rounded, the dorsal furrow interrupted in front by a triangular depression, base with a large oblong smooth fovea on each side. Elytra ovate, moderately striated, the striæ impunctate, having four or five impressed dots between the second and third strix; body beneath pitchy black, breast and abdomen niore or less rufescent; legs pitchy red. Length 4-5 lines.

A local species: "in profusion at Castle Howard, Yorkshire; Devonshire; Norfolk; Bottisham,Cambridgeshire," Mr. Stephens. "Bamburgh, Twizell and Bradley Mill, Northumberland," Mr. T.J.Bold. Leicester and the midland counties; Coombe Wood, \&c. Frequent also in many parts of Scotland and Ireland.

2. C. Cisteloides : apterus, niger; thorace subquadrato, anticè angustato, posticè utrinque impresso punctatoque, angulis posticis rectis; elytris striatis, striis subtilissimè punctatis, interstitiis tertio quintoque punctis remotis impressis; pedibus rufis vel piceo-nigris.

Carabus Cisteloides, Panz. Faun. 11.-Ill. Käfer, 1.163.

Harpalus Cisteloides, Gyll. Ins. Suec. 2. 125.

Calathus Cisteloides, Dej. Spec. 3. 65 ; Icon. 2. 299. pl. 110.Steph. Mand. 1. 99, et Manual, p. 29.

Carabus frigidus, Fab. S. El. 1. 189.

Wingless, black, palpi and antennæ pitchy, basal joint of the latter red. Thorax subquadrate, narrowest in front, sides nearly straight behind and the posterior angles right angles, disk much wrinkled, with a large oblong punctured impression on each side at the base, which is also rugose. Elytra oblong-ovate, striated, the strix obsoletely punctured, the third and fifth interstices with several larger impressions and about six at the extremity of the second; legs red, tarsi pitchy, sometimes the legs are wholly pitchy black, which variety represents the Carabus obscurus of Marsham. Length 4-6 lines.

Common.

3. C. flavipes : apterus, nigro-piceus; thorace subquadrato, anticè subangustato, posticè utrinque impresso, angulis posticis rectis; elytris obsoletissimè viridi-micantibus, striatis, interstitio tertio punctis duobus impressis; antennis pedilusque rufis.

Buprestis favipes, Fourc. Ent. Paris. 1. 43 (1785). 
Carabus favipes, Dufts. Faun. 2. 122.

Calathus favipes, Sturm, D. F. 5. 115.-Steph. Mand. 5.375, et Manual, p. 29.

Harpalus fulvipes, Gyll. Ins. Suec. 2. 128.

Calathus fulvipes, Dej. Spec. 3. 70 ; Icon. 2. 307. pl. 111.Erichson, Käfer, 102.

C. crocopus, Steph. Mand. 1. 99, et Manual, p. 29.

Rather more parallel than Cisteloides, pitchy black, very shining, sometimes with a greenish tinge on the elytra of the $\sigma^{\circ}$, dull pitchy black in the $q$. Thorax with its margins reddish, disk smooth, dorsal furrow interrupted before and behind, base smooth and with an obsolete impunctate fovea on each side. Elytra finely striated, the third interstice with two impressions only and none on the fifth, which character serves at once to distinguish it from Cisteloides; palpi, antennæ and legs red. Length 4-5 lines.

This insect appears to be the Buprestis flavipes of Fourcroy's work. The Carabus flavipes of Paykull's monograph can scarcely (judging from the description) be reconciled with it.

It is abundant in sandy districts.

4. C. fuscus: alatus, fusco-piceus; thorace subquadrato, utrinque obsoletè impresso, angulis posticis acutis ; elytris subtilitèr striatis, punctis duobus impressis; antennis pedibusque testaceis.

Carabus fuscus, Fab. Ent. S. 1. 158.-Fab. S. El. 1. 184.

Harpalus fuscus, Gyll. Ins. Suec. 2. 126.

Calathus fuscus, Sturm, D. F. 5. 109.-Dej. Spec. 3. 71 ; Icon.

2. 308. pl. 111.-Steph. Mand. 1. 100, et Manual, p. 29.Erichson, Käfer, 103.

Carabus rufangulus, Marsham, Ent. 441.

Calathus rufangulus, Steph. Mand. 1. 100, et Manual, p. 29.

Carabus mifipes, Fab. S. El. 1. 184.

Much broader than any of the preceding and entirely fuscous brown, with the margins of the thorax, the palpi, antennæ and legs livid testaceous. Head smooth and convex, with an impression on each side between the eyes. Thorax subquadrate, narrowed in front, broad and straight behind, with the posterior angles slightly acute, disk with a deep central line, transversely wrinkled, and a very broad slightly impressed fovea on each side at the base. Elytra ovate, broader than the thorax, sides regularly rounded, finely striated, with two impressed dots between the second and third striæ and the usual series on the margin. Length $4 \frac{1}{2}-5$ lines. 
Extremely abundant on the Chesil bank and other sandy commons near the southern coasts of England and Wales.

5. C. mollis : apterus, fusco-piceus; thorace subquadrato, anticè subangustato, margine rufo-testaceo, basi utrinque levitèr impresso, angulis posticis subrotundatis; elytris oblongoovatis, subtiliter striatis punctisque tribus impressis; antennis pedibusque pallidè testaceis.

Carabus mollis, Marsham, Ent. 450.

Calathus mollis, Steph. Mand. 1. 101, et Manual, p. 29.

Carabus ochropterus, Dufts. Faun. 2. 124.

Calathus ochropterus, Dej. Spec. 3. 79; Icon. 2. 313. pl. 112. -Heer, Faun. Helv. 56.

Wingless, pitchy brown, with the margins of the thorax testaceous, palpi and antennæ pale testaceous. Thorax subquadrate, a little narrowed in front, sides very nearly parallel behind, posterior angles obtuse, dorsal furrow very slender, base depressed and furnished with a very shallow smooth fovea on each side. Elytra oblong-ovate, narrowed before and behind, so that the sides appear very much rounded and distinctly widest in the middle, very finely striated, the third interstice with from three to (sometimes) five impressions; legs pale testaceous. Length $3 \frac{1}{2}$ lines.

Its smaller size and more quadrate thorax, with obtuse hinder angles, immediately distinguish this speciesfrom smaller examples of fuscus.

A very abundant species on sandy commons near the coast in England, Scotland and Ireland.

6. C. melanocephalus : apterus, nigro-piceus; thorace rufo, subquadrato, anticè angustato, basi utrinque levitèr impresso, angulis posticis obtusis; elytris ovatis, subtilitèr striatis punctisque tribus impressis; antennis pedibusque testaceis.

Carabus melanocephalus, Linn. F. S. 795 ; S. N. 2. 671.Fab. S. El. 1. 190.

Harpalus melanocephalus, Gyll. Ins. Suec. 2. 129.

Calathus melanocephalus, Sturm, D. F. 5. 116.-Dej. Spec. 3. 80 ; Icon. 2. 316. pl. 112.-Steph. Mand. 1.98, et Manual, p. 29.-Erichson, Käfer, 101.-Heer, Faun. Helv. 56.

C. apicalis, Newman, Ent. Mag. 1. 287.-Steph. Mand. 5. 375, et Manual, p. 29.

Wingless, black or pitchy black, with the thorax entirely and 
the margins of the elytra narrowly red. Head black, depressed in front, palpi and antennæ testaceous. Thorax subquadrate, shorter and broader than in the preceding species or either of the following, distinctly contracted in front, the sides parallel from the middle to the base, which is truncate, and the posterior angles obtuse, the dorsal line slender, terminating before and behind in a depressed space, the disk on each side of it finely wrinkled transversely, the base furnished with a shallow impression on each side more or less slightly evident. Elytra a little wider than the base of the thorax, ovate, apex rounded, finely striated, having two impressions between the second and third striæ; legs testaceous red. Length $3 \frac{1}{2}$ lines.

There are varieties in which the thorax is more or less pitchy. C. apicalis, Newman, is an immature example of this species, which is very common everywhere.

7. C. micropterus : apterus, niger, nitidus; thorace subquadrato, anticè posticèque subangustato, basi utrinque profundè foveolato, angulis posticis subrotundatis; elytris oblongo-ovatis, striatis punctisque tribus impressis; antennis pedibusque testaceis.

Carabus micropterus, Dufts. Faun. 2. 123.

Calathus micropterus \&, Sturm, D. F. 5. 113.-Steph. Mand. 5. 437, et Manual, p. 29.-Heer, Faun. Helv. 55.

Harpalus micropterus, Gyll. Ins. Suec. 4. 442.

Calathus microcephalus, Dej. Spec. 3. 78; Icon. 2. 313.pl. 112. -Heer, Faun. Helv. 55.

C. glabripennis oे, Sturm, D. F. 5. 118.

Wingless, black (or pitchy black), very shining; mandibles, palpi, antennæ and legs (and sometimes the lateral margins of the thorax narrowly) testaceous red. Head convex, smooth and shining, with a fovea on each side in front between the antennæ and a slight double impression on the crown, the fifth to the last joints of the antennæ rather stout. Thorax subquadrate, rather narrowed in front and rounded below the anterior angles, slightly narrowed also behind, with the margins slenderly reflexed and the posterior angles obtuse, disk convex, the central line deep at the base, and a deeply impressed roundish fovea on each side near the hinder angles which are otherwise slightly rugose. Elytra oblong-ovate, shoulders rounded and a little narrowed, sides very slightly rounded, disk convex, finely striated, some of the striæ very obsoletely punctured, the third with three deeper impressions near- one another before the middle, and the second with one placed further behind. Length $3 \frac{1}{2}-4$ lines. 
The more rounded lateral margins of the thorax and the deeper basal impressions, together with the less rounded and dilated sides of the elytra and its uniform dark colour, sufficiently distinguish this insect from either of the preceding.

It is a mountain species, but rather rare. I have captured the insect on several occasions on the high moors near Llangollen, in August and September : it is found also in Scotland in similar situations. "Near the summit of Hedgehope in July," Mr. Hardy.

8. C. nubigena : subapterus, niger; thorace quadrato, anticè subangustato, basi utrinque levitèr impresso; elytris oblongis, subparallelis, striatis, punctis 3 vel 4 impressis; antennarum basi pedibusque rufescentibus. (PI. I. f. D.)

Haliday, Ann. N. Hist. 2. 112 (1839).-Curtis, Guide, 53. 5.

Oblong, black, elytra sometimes with a greenish gloss. Head small and narrow, palpi and antennæ pitchy, three joints at the base of the latter and the extreme tip of the former reddish. Thorax quadrate, narrowed in front, sides scarcely rounded, but again very slightly contracted just before the posterior angles, which are obtuse, dorsal furrow very faint, base with two oblong rather parallel, shallow foveæ. Elytra oblong, subparallel or with the sides very slightly rounded, distinctly striated, the three striæ nearest the suture are carried to the apex, the fourth joins the third by a slight curve before the apex, the fifth and sixth are abbreviated and unite behind the middle, the seventh is carried round the others and joins the third at the extremity, the eighth is carried quite round to the tip and always bears a series of remote round impressed punctures from the shoulder to almost the extremity, each elytron has likewise four distinct impressions, placed one at the junction of the first and second strix near the scutellum, and three on the third stria about the middle, sometimes however these are partially or wholly wanting and occasionally there are two smaller punctures on the second stria nearer the apex; breast and thorax on the underside pitchy, abdomen shining black, legs rufescent. Length 3 lines.

This insect appears to be variable in colour; of the three examples now before me one is shining black with the tip of the palpi and of the mandibles, the basal joint of the antennæ and the legs red, the breast and thorax on the underside being pitchy ; in another individual the thorax is red beneath and pitchy above; while in a third it is wholly red and the palpi entirely and three joints at the base of the antennæ ferruginous red, which variations do not apparently result from different degrees of maturity 
in these individual specimens. It is rather smaller than mollis, and has a very dissimilar form; the head is both smaller and narrower, the antennæ more robust, especially from the fifth joint and upwards, in which respect it resembles micropterus, these are likewise more pubescent, and never in paler nor in less mature individuals are they, as Mr. Haliday informs us, entirely red, though sometimes one and sometimes two or three joints at the base may be paler; the thorax is more narrowed in front and less narrowed behind than in mollis, and the basal foveæ narrower and more parallel to the sides; the elytra are broader in front, with their sides more parallel and not as in mollis more rounded and dilated in the middle, so as to appear as in that insect distinctly narrowed before and behind, the striæ likewise are deeper.

This very interesting addition to the British fauna was discovered by Mr. Haliday on the Irish mountains : "Slubh Donard, Downshire, 2700 feet above the sea ; on Lugnaquilla, 3000 feet, and other mountainous ranges in Wicklow, among the piled-up stones, early in the summer, but later in the season they were not to be found." $A . H . H$.

\section{Genus 30. SYNUCFUS, Gyllenhal.}

Mentum dente medio bifido. Ligula apice rotundata; paraglossis eam paulò superantibus. Palpi maxillares articulo ultimo cylindrico, truncato ; labiales articulo ultimo levitèr securiformi. Mandibulæ subarcuata, acuta. Labrum quadratum, truncatum. Tarsi antici maris articulis tribus levitèr dilatatis, subtùs biseriatìm pectinato-setosis.

1. S. vivalis : nigro-piceus, nitidus; thorace subrotundato; elytris oblongo-ovatis, striatis, punctis duobus vel tribus impressis ; antennis pedibusque rufis.

Carabus vivalis, Panz. Faun. 37.-Dufts. Faun. 2. 140.

Synuchus vivalis, Gyll. Ins. Suec. 2. 77.-Steph. Mand. 1. 97, et Manual, p. 28.-Heer, Faun. Helv. 57.

Agonum vivale, Sturm, D. F. 5. 215.

Taphria vivalis, Dej. Spec. 3. 83 ; Icon. 2. 321. pl. 115.Erichson, Käfer, 101.

Pitchy black, very shining. Head smooth with a slight impression on each side between the antennæ and a transverse stria in front; mouth, palpi and antennæ testaceous red. Thorax very wide in front and dilated at the sides, the lateral margins and posterior angles much rounded, convex, with a fine dorsal stria and an impression on each side at the base. Elytra oblong- 
ovate, rather wider than the thorax, convex, striated, the striæ impunctate, except that there are two or three impressions on the second from the suture and an irregular series on the outer margin ; the margins of the thorax and of the elytra are sometimes very narrowly edged with ferruginous; legs pale red. Length $3 \frac{1}{2}$ lines.

Rather local, but somewhat widely distributed; on banks of rivers in the midland counties; in the Isle of Wight; near Dorchester; Dorking; North Wales ; Yorkshire, and other northern counties, and also in Scotland and Ireland. "On damp banks at Coombe; Darenth; Bottisham; Netley; in Norfolk, \&c." Mr. Stephens.

\section{Genus 31. ANCHOMENUS, Auctorum.}

Mentum dente medio integro. Ligula apice truncata; paraglossis ei aqualibus. Palpi articulo ultimo cylindrico. Mandibulæ subarcuata, acuta. Labrum quadratum, apice truncatum. Tarsi antici maris articulis tribus dilatatis, unguiculi simplices.

This genus comprehends Platynus, Anchomenus and Agonum, which had been established by Bonelli on the ground of certain differences in the external structure of the thorax and elytra, the posterior angles of the former being obtuse in those species assigned by him to Agonum, but acute and prominent in those arranged under Platynus and Anchomenus; and the two latter genera were furthermore represented as being distinguishable from each other by a supposed variation in the form of the elytron. It appeared, however, upon examination of a series of species, that these characters were altogether artificial, some species in one genus bearing a greater affinity to those of another genus with which by such an arrangement they were so far disconnected, than to those with which they were placed in immediate juxtaposition; and not only so, but these characters prevailed equally if not more so in other genera with which they were not grouped at all; consequently these subdivisions have now been altogether abandoned (or treated by some authors as subgenera), and the genus Anchomenus has been generally adopted to comprise the whole, that name demanding the preference, because Platynus, though employed for the same purpose by Brulle, had previously been appropriated in another order (Diptera).

\section{(Platynus, Bonelli.)}

1. A. junceus : niger, nitidus; thorace cordato, latè marginato, angulis posticis acutiusculis ; elytris ovatis, striatis punctisque tribus impressis; ore antennis pedibusque piceo-brunneis. 
Carabus junceus, Scop. Ent. Carn. 89 (1761).

C. angusticollis, Fab. S. El. 1. 182.

Harpalus angusticollis, Gyll. Ins. Suec. 2. 81.

Anchomenus angusticollis, Sturm, D. F. 5. 168.-Dej. Spec. 3.

104 ; Icon. 2. 343. pl. 116.-Erichson, Käfer, 108.-Heer,

Faun. Helv. 57.

Platynus angusticollis, Steph. Mand. 1. 83, et Manual, p. 25.

Shining black. Head oblong, very smooth with an impression on each side, mouth, palpi and base of the antennæ pitchy, the apical joints of the latter fuscous. Thorax widest in front a little below the anterior angles and much rounded in that part, then obliquely sloped and narrowed till just before the posterior angle, when it forms with the base a right angle with the apex a little acute and prominent, disk convex, the central line met in front by a deeper impression, the base with two deep fover. Elytra broad, dilated behind the middle, the apex obliquely sinuated and produced, deeply and regularly striated, the striæ very obsoletely punctured, interstices elevated, the third with three distinct remote impressions; legs brownish. Length $4 \frac{1}{2}-5$ lines.

The name given to this species by Scopoli is restored in right of priority.

Locally abundant under bark of trees, \&c.

\section{(Anchomenus, Bonelli.)}

2. A. livens : nigro-piceus; thorace oblongo-cordato, angulis posticis subrotundatis; elytris oblongis, levitèr striatis; antennis pedibusque rufo-ferrugineis.

Harpalus livens, Gyll. Ins. Suec. 2. 149.

Agonum livens, Steph. Mand. 1. 95, et Manual, p. 28.

Anchomenus livens, Erichson, Käfer, 108.

An. memnonius, Nicol. Col. Agr. Hal. 17. 1.-Sturm, D. F. 5. 170.-Dej. Spec. 3. 110 ; Icon. 2. 345. pl. 116.

Agonum bipunctatum, Sturm, D. F. 5. 184.

Pitchy black, shining. Head very smooth, with a small fovea on each side at the base of the antennæ and two indistinct red dots between the eyes; palpi and antennæ rusty red, with the base of the second, third and fourth joints of the latter dusky. Thorax oblong, heart-shaped, anterior margin rather straight, sides rounded in front, obliquely narrowed behind, posterior angles also rounded, base with two deep foveæ, disk with numerous transverse wrinkles on each side the impressed dorsal furrow. Elytra rather oblong, shoulders rounded and slightly prominent, sides widest behind the middle, moderately striated, margins with 
a series of deep impressions; underside smooth and impunctate, legs red. Length 4 lines.

Very rare. "Bognor; Hastings; Brighton ; and on the Norfolk coast." Mr. Stephens. In August and September 1849, I captured three specimens in Eridge Wood, near Tunbridge Wells. Mr. Janson obtained one last year in Highgate Wood, at sugar placed to attract Noctua.

3. A. dorsalis : capite thoraceque viridibus, hoc angustato subcordato, angulis posticis subrectis; elytris oblongo-ovatis, striatis, ferrugineis, macula communi posticâ viridi-cyaneâ ; antennarum basi pedibusque ferrugineis.

Carabus dorsalis, Müller, Prod. Zool. Dan. 78 (1776).

Buprestis bicolor, Fourc. Ent. Paris, 1. 44 (1785).

Carabus prasinus, Thunb. Nov. Spec. 4. 74. f. 87 (1785).-Fab. Mant. 1. 204 (1787).-Payk. Mon. 57 (1790).

Harpalus prasinus, Gyll. Ins. Suec. 2. 83.

Anchomenus prasinus, Sturm, D. F. 5. 171.-Dej. Spec. 3. 116 ; Icon. 2. 347. pl. 117.-Steph. Mand. 1. 82, et Manual, p. 25. -Erichson, Käfer, 118.-Heer, Faun. Helv. 58.

Carabus viridanus, Fab. Mant. 1. 204.-Payk. Mon. 57.

The head and thorax are green, the elytra testaceous with a large blue-black or greenish cyaneous patch on the disk common to both and extending from above the middle to the apex, leaving the margins broadly testaceous. Head large, convex, smooth, having an impression on each side at the base of the antennæ, the latter are rusty red, with their base and the palpi paler. Thorax subcordate, narrow, widest below the anterior angles and rounded in that part, then contracted till just before the posterior angles, which are almost right angles and slightly elevated, the dorsal line abbreviated and met before and behind by a transverse impression, the base also has two oblong fovex. Elytra oblongovate, the humeral angles and sides rounded, the apex obliquely sinuated, punctate-striated, having three larger impressions on the third interstice and a series next the eighth stria; legs pale red. Length 3 lines.

This species is described under the name $C$. dorsalis, in Müller's 'Prodromus,' which consequently claims priority.

Commonly distributed.

4. A. pallipes: alatus, nigro-piceus; thorace cordato posticè coarctato punctatoque, angulis posticis acutiusculis; elytris oblongo-ovatis, striatis, margine plerumque rufescente; antennis pedibusque pallidis.

Carabus pallipes, Fab. Mant. 1.202(1787).-Fab. S. El.1.187. 
Anchomenus pallipes, Dej. Spec. 3. 119; Icon. 2.349. pl. 117.Heer, Faun. Helv. 58.

Carabus albipes, Fab. S. El. 1. 187.

Harpalus albipes, Gyll. Ins. Suec. 2. 82.

Anchomenus albipes, Sturm, D. F. 5. 175.-Steph. Mand. 1. 82, et Manual, p. 25.-Erichson, Käfer, 118.

Winged, pitchy black or rusty red, with the margins of the elytra sometimes paler; antennæ ferruginous, the base and palpi pale. Thorax cordate, delicately margined, much contracted behind, posterior angles minute and acute, disk faintly channeled and transversely wrinkled, base depressed and strongly punctured and with two oblong foveæ. Elytra very broad, ovate, shoulders rounded, simply striated, with three impressions on the third interstice and a series near the outer margin; legs pale. Length $3 \frac{1}{2}$ lines.

Very common.

5. A. oblongus : apterus, rufo-piceus; thorace elongato angustato, posticè punctato, angulis posticis acutiusculis ; elytris punctato-striatis; antennis pedibusque pallidis.

Carabus oblongus, Fab. Ent. S. 1.140 (1792).-Fab. S, El. 1. 185.

Harpalus oblongus, Gyll. Ins. Suec. 2. 99.

Anchomenus oblongus, Sturm, D. F. 5. 173.-Dej. Spec. 3. 121 ; Icon. 2. 351. pl. 117.-Steph. Mand. 1. 82, et Manual, p. 25. -Erichson, Käfer, 118.-Heer, Faun. Helv. 59.

Wingless, pitchy or rusty red. Head elongate, smooth and shining with an impression on each side between the antennæ which with the palpi are ferruginous red. Thorax elongate and narrowed, widest in front below the angles and rather rounded, contracted behind, posterior angles prominent, disk convex, sides and base not depressed, but much punctured, the dorsal furrow very indistinct and terminating in front in numerous small punctures. Elytra oblong-ovate, narrowest at the shoulders, sides sinuated before the middle, dilated behind and the apex rounded, very convex, deeply punctate-striated, pitchy castaneous; legs pale testaceous. Length $2 \frac{3}{4}$ lines.

Rather local, but extremely abundant in marshy places.

(AgONum, Bonelli.)

6. A. marginatus : viridis, nitidus ; thorace lateribus subrotundato; elytris oblongo-ovatis, subtilitèr striatis, punctis tribus impressis, margine tibiisque flavo-pallidis. 
Carabus marginatus, Linn. F. S. 804.-Fab. S. El. 1. 199.

Harpalus marginatus, Gyll. Ins. Suec. 2. 154.

Agonum marginatum, Dej. Spec. 3. 133; Icon. 2. 355. pl. 118.

-Steph. Mand. 1. 85, et Manual, p. 25.

Anchomenus marginatus, Erichson, Käfer, 109.

Rich satiny green, head and thorax with a coppery tinge, rarely dark purplish green, the lateral margins of the thorax narrowly, the entire margins of the elytra broadly edged with yellow. Head finely wrinkled, eyes prominent, antennæ pitchy black, basal joint testaceous. Thorax short, sides regularly and equally rounded, posterior angles rounded, disk very much wrinkled, the dorsal furrow fine, terminating before in a deeper curved impression, base with two foveæ close to the hinder angles. Elytra broad, shoulders rather elevated and rounded, sides somewhat parallel, apex produced, finely striated, interstices flat, the third with three deep punctures and a series on the margin, suture dull reddish copper; legs pitchy black, tibiæ pale yellow. Length $4 \frac{1}{2}$ lines.

Plentiful in marshy places, banks of streams, \&c.

7. A. sexpunctatus : capite thoraceque viridi-aneis, hoc transverso, angulis posticis rotundatis; elytris rubro-cupreis, subtilitèr punctato-striatis, interstitio tertio punctis sex impressis.

Carabus sexpunctatus, Linn. F. S. 807.-Fab. S. El. 1. 199. Harpalus sexpunctatus, Gyll. Ins. Suec. 2. 156. Agonum sexpunctatum, Sturm, D. F. 5. 202.-Dej. Spec. 3. 140; Icon. 2. 360. pl. 118.-Steph. Mand. 1. 86, et Manual, p. 25. Anchomenus sexpunctatus, Erichson, Käfer, 110.

Head and thorax brilliant green, brassy, sides of the latter reddish copper; palpi and antennæ black. Thoraw transverse, broad, sides rounded below the anterior angles, also rounded and narrowed behind, margins reflexed, and together with a broad punctate fovea near each hinder angle very rugose and punctured, the disk also transversely wrinkled, and faintly channeled down the centre. Elytra broad and short, rather widest behind the middle, otherwise the sides appear almost straight, apex slightly produced, rather more convex than marginatus, very finely striated, the striæ faintly punctured, interstices slightly rugose, the third with six deep impressions, more rarely with five, seven or eight, and a series on the external margin most frequent at the base and near the apex, the entire surface is brilliant coppery red, very shining, with the scutellum and entire margin green; underside dark grcen, legs brassy 
black, femora, and occasionally the tibiæ greenish black. Length $3 \frac{1}{2}$ lines.

This brilliant species varies occasionally in colour, being sometimes golden green, purplish or violet, rarely obscure black. It is somewhat local, but occasionally abundant. Rather plentiful in a damp wood near Newark, Notts; Gamlingay and Paxton Woods ; Coombe Wood; Epping Forest; Hertford, \&c. I have also taken it on the coast, near Ramsgate.

8. A. modestus: capite thoraceque cupreo-aneis, elytris subparallelis, viridibus, suturấ cupreo-aneâ, tenuè punctatostriatis, punctis 6 impressis; antennis pedibusque nigris.

Agonum modestum, Sturm, D. F. 5. 205.-Dej. Spec. 3. 138 ; Icon. 2. 359. pl. 118.

Anchomenus modestus, Erichson, Käfer, 109.

Carabus Austriacus, Dufts. Faun. 2. 135.

Agonum Austriacum, Curtis, Ent.pl. 183.-Steph. Mand. 1.87, et Manual, p. 26.

Head and thorax coppery with a greenish tinge, the former oblong and narrowish; palpi and antennx black. Thorax quadrate, short; sides regularly and equally rounded from the anterior angles to the base, lateral margins reflexed and rather elevated at the hinder angles and somewhat rugose, the angles scarcely rounded, disk very much wrinkled transversely, with an impressed dorsal line, and two broad, deep, subpunctate fover at the base. Elytra wide, sides almost parallel, apex obliquely sinuated, green, with the suture obscure coppery as far as the first stria, finely striated, some of the striæ at the base minutely punctured, interstices flat, the third with six punctures, and the outer margin with a series of deeper impressions most numerous at the base; body beneath greenish black, sides of the head green and transversely strigose; legs black. Length 4 lines.

This insect is distinct from C. Austriacus, Fab., though it is identical with Carabus Austriacus, Dufts., and Agonum Austriacum of Dejean's Catalogue. It is much more slender, the thorax is smaller, narrower and shorter, not much contracted behind as in that species, nor the sides so widely margined, and the hinder angles are less rounded and less obtuse, in which respects it accords more with the form of marginatus, while Austriacus corresponds with 6-punctatus in the structure of the thorax; the elytra also are narrower and more parallel, not oblong-ovate as in Austriacus, and instead of a wide coppery common streak at the base, have the suture alone as far as the first stria dull coppery or purplish copper. 
Extremely rare in Britain, the only localities recorded being "Kingsbridge, Devon; Clengre, Gloucestershire; and in Cornwall," in the spring.-Mr. Stephens.

9. A. fulgens : igneo-cupreus; thorace lateribus rotundato ; elytris oblongo-ovatis, striatis, striis subtilitèr punctatis, punctisque majoribus 4, 5 aut 6 impressis.

Agonum fulgens, Davis, Loudon's Mag. Nat. Hist. 5. 247.Steph. Mand. 5. 374, et Manual, p. 26.

Brilliant fiery copper tinged with purple and green, margins of the thorax and of the elytra golden green, the suture also occasionally greenish. Head smooth behind, transversely strigose in front, with a small fovea on each side at the base of the antennæ; mouth, palpi and three joints at the base of the antennæ black with greenish reflections, apical joints fuscous. Thorax subquadrate, sides moderately rounded and narrowed behind, margins broadly reflexed and with two large foveæ at the base very rugose, the rest of the disk transversely strigose and the dorsal furrow distinctly marked. Elytra oblong-ovate, slightly widest behind the middle, apex obliquely sinuated, very finely punctate-striated, with five distinct impressions between the second and third striæ, and in some examples another nearly at the termination of the seventh, and an irregular series on the margin deepest at the apex; body beneath dark shining green with a brassy tinge, femora and tibiæ shining black with a coppery reflection, tarsi wholly black. Length 3 lines.

Dr. Schaum in his remarks on the Stephensian species (Ent. Zeitung), observes that this insect " is identical with $A$. Ericeti." I have compared it with typical examples of the latter insect which Mr. Wollaston brought from Dr. Heer of Zurich, and find that it is perfectly distinct. A. Ericeti is a variety of A. sex-punctatus, and is so recorded in Heer's Fauna Helvetica, p. 61 ; but it is impossible, after the most careful examination, to connect the present species with that insect.

It is found upon the high moors at Hebden Bridge, Luddenden Foot, \&c., near Halifax, and on other moors near York, early in the spring. "Rare near Paisley," Mr. M. Young.

10. A. læevis: capite thoraceque viridi-ceneis, hoc transverso, angulis posticis rotundatis; elytris fusco-aneis, subtilitèr striatis, interstitio tertio punctis tribus impressis; antennis basi tibiisque testaceis.

Carabus levis, Müller, Prod. Zool. Dan. 78 (1776). 
C. parumpunctatus, Fab. Ent. S. 1. 157 (1792).-Fab. S. El. 1. 199.

Harpalus parumpunctatus, Gyll. Ins. Suec. 2. 157.

Agonum parumpunctatum, Sturm, D. F. 5. 210.-Dej. Spec. 3. 143 ; Icon. 2. 363. pl. 119.-Steph. Manual, p. 26.

Anchomenus parumpunctatus, Erichson, Käfer, 111.-Heer, Faun. Helv. 61.

Agonum plicicolle, Nicol. Col. Agr. Hal. 19.6.-Steph. Mand. 1. 87 .

Head and thorax greenish brass, antennæ fuscous black, with the basal joint red. Thorax in form like that of 6-punctatus, being widest in front with the sides rounded, a little narrowed behind, finely margined and the edges reflexed, especially at the posterior angles which are likewise rounded, disk transversely wrinkled and furnished with a fine dorsal furrow, the base with two foveæ. Elytra brownish brass, the shoulders rather prominent and rounded, the sides widest behind the middle, and the apex obliquely sinuated, finely striated, the striæ obsoletely punctured, and with three or four deeper impressions on the third interstice and a series on the external margin; body beneath black, thighs greenish black with their base pitchy red, tibiæ and tarsi testaceous. Length $3 \frac{1}{2}-4$ lines.

The name given to this species by Müller ought to receive the preference. The insect is variable in colour, presenting different shades of green, coppery or brassy, or blue-black, and is very common.

11. A. viduus : obscurè viridi-æneus; thorace lato transverso, angulis posticis rotundatis; elytris ovatis, punctato-striatis, interstitiis convexiusculis tertio tripunctato.

Carabus viduus, Panz. Faun. 37.

Harpalus viduus, Gyll. Ins. Suec. 2. 153.

Agonum viduum, Sturm, D. F. 5. 185.-Dej. Spec. 3. 149 ; Icon. 2. 368. pl. 119.-Steph. Mand. 1. 88, et Manual, p. 26. Anchomenus viduus, Erichson, Käfer, 114.-Heer, Faun. Helv. 62.

Larger than lavis, but resembling it in form. Head black, smooth and shining, with an oblong impression on each side between the antennæ, which with the palpi are black. Thorax greenish black or olivaceous or entirely black, the breadth in the middle greater than the length, sides rounded and deeply margined and the margins broadly reflexed, especially at the hinder angles, which are rounded, disk transversely strigose, the dorsal furrow met in front by a curved impression, the basal angles each with a large fovea. Elytra greenish brass, ovate, 
much broader than the thorax, shoulders rounded and sometimes elevated, sides widest behind the middle, apex obliquely sinuated, moderately convex, deeply striated, the striæ obsoletely punctured, interstices convex, the third from the suture with three punctures and the margin with a series of deeper impressions; body beneath and legs black. Length 4 lines.

This insect is not uncommon in marshy places, in damp woods under moss and chips of bark, and is widely distributed; in profusion in Eridge Woods in autumn.

12. A. mœestus : niger, subnitidus ; thorace lateribus rotundato ; elytris ovatis, striatis, striis subtilissimè punctulatis, interstitiis convexiusculis tertio tripunctato.

Carabus mostus + , Dufts. Faun. 2. 138. Agonum moestum, Sturm, D. F. 5. 187.-Steph. Mand. J. 89. Carabus afer ठ, Dufts. Faun. 2. 138. Agonum afrum, Sturm, D. F. 5. 188.-Steph. Mand. 1. 89. Ag. versutum et lave, Steph. Mand. 1. 88, et Manual, p. 26. Harpalus emarginatus, Gyll. Ins. Suec. 4. 450. Agonum emarginatum, Dej. Spec. 3. 154 ; Icon. 2.372. pl. 120. -Steph. Mand. 1. 89, et Manual, p. 26.

This species is rather smaller than viduus, which it very much resembles in form, but the thorax is narrower, which gives it a somewhat longer appearance; the elytra are black without any tinge of green. Thorax with the sides rounded but less dilated than in viduus, rather narrowed behind, widely margined, base with two broad impunctate foveæ. Elytra ovate, widest behind the middle, apex very slightly sinuated, striated, the striæ very finely punctulated, the third interstice with two impressions before the middle and another close to the second stria nearer the extremity; underside and legs black. Length 4 lines.

Harpalus emarginatus, Gyll., is a not unfrequent variety with the humeral angles of the elytra elevated. Agonum afrum, lave, versutum and Bogemanni of the Stephensian cabinet must be referred to this species, which is very abundant in marshy places and damp woods throughout the kingdom.

13. A. atratus: niger, nitidus; thorace angustiore, lateribus subrotundato; clytris striatis, striis obsoletè punctatis; antennis pedibusque piceis.

Carabus atratus, Dufts. Faun. 2. 138.

Agonum atratum, Sturm, D. F. 5. 189.

Ag. nigrum, Dej. Spec. 3. 157; Icon. 2. 376. pl. 121.

The form of this species is intermediate between those of 
moestus and fuliginosus; it is deep shining black. Head smooth, mouth reddish, palpi and base of the antennæ pitchy, apex of the latter fuscous black. Thorax narrower than in moestus and the sides less rounded, margins less reflexed, posterior angles likewise less evidently rounded, but more obliquely sloped to the base and the basal foveæ smaller. Elytra oblong-ovate, rounded at the sides but very slightly widest behind the middle, apex obliquely sinuated, striated, striæ very faintly punctured, interstices flat, the third with three minute punctures; legs pitchy black. Length $3 \frac{1}{2}$ lines.

Found in Hants; Cornwall and other western counties of England; abundant near Bristol.

14. A. fuliginosus : piceo-niger, nitidus; thorace lateribus rotundato, posticè angustato, angulis posticis rotundatis; elytris ovatis, striatis, striis obsoletissimè punctatis, interstitio tertio punctis quinque impressis; pedibus rufo-piceis.

Carabus fuliginosus, Panz. Faun. 108.

Agonum fuliginosum, Sturm, D. F. 5. 192.-Dej. Spec. 3. 163; Icon. 2. 380. pl. 122.-Steph. Mand. 1.93, et Manual, p. 27. Anchomenus fuliginosus, Erichson, Käfer, 117.

Agonum 4-punctatum, Steph. Mand. 1. 90, et Manual, p. 26.

Ag. piceum, Steph. Mand. 1. 91.

Ag. Simpsoni, striatum et pullum, Steph. Mand. 1. 92.

Ag. fuscipenne, Steph. Mand. 1. 93, et Manual, p. 27.

Ag. gracile, Steph. Mand. 1. 94.

Ag. pusillum, Steph. Mand. 1. 95, et Manual, p. 28.

Head black, with an oblong fovea on each side at the base of the antennæ, which together with the palpi are pitchy black, mandibles usually pitchy red. Thorax (PI. II. f. 1) with the sides regularly rounded and gradually narrowed towards the base, which is about two-thirds the width of the anterior part, posterior angles likewise somewhat rounded, disk convex, smooth and shining on each side the dorsal line, which terminates before and behind in a distinct impression, base with two oblong smooth foveæ. Elytra ovate, rather narrowed in front and rounded at the angles, sides then widening till behind the middle, but lessening at the apex, striated, strix obsoletely punctured, with occasionally but not always four or five more distinct impressions between the second and third strix; the colour varies from pitchy black to pitchy testaceous; the legs are always more or less pitchy brown. Length 3 lines.

The insects recorded by Stephens under the names Simpsoni, pullum, striatum, pusillum and fuscipenne, belong to this species. The supposed examples of Agonum gracile, piceum and 4-puncta- 
tum, contained in the Stephensian collection, must likewise receive the same reference. This insect is very common in marshy places, on river banks, \&c.

15. A. gracilis: niger, nitidus; thorace subquadrato, angulis posticis rotundatis; elytris oblongo-ovatis, subtilitèr striatis, punctis quinque impressis ; antennis pedibusque totis nigris.

Agonum gracile, Sturm, D. F. 5. 197.-Dej. Spec. 3. 162 ; Icon. 3. 379. pl. 121.

Harpalus gracilis, Gyll. Ins. Suec. 4. 449.

Anchomenus gracilis, Erichson, Käfer, 116.

Agonum atratum, Steph. Mand. 1. 91, et Manual, p. 27.

This species is much more delicately formed than the preceding and differs in several particulars. The thorax is more quadrate, not so wide in front, nor so much narrowed at the base, but the hinder angles are more broadly rounded; the elytra are less ovate, the shoulders not so much narrowed but broader and more prominent, the sides less rounded in the middle, but straighter and the apex broader, they are also much more delicately striated; and the entire surface of the insect, including the antennæ, palpi and legs, is uniformly black. Length 3 lines.

The only locality in which I have found the insect is Eridge Wood, near Tunbridge Wells. "Dalmeney Park and near Paisley," Murray's Catalogue.

16. A. scitulus : niger, nitidus; thorace obcordato, posticè angustato; elytris oblongo-ovatis, subvirescentibus, subtiliter striatis, punctis quinque impressis; pedibus nigro-piceis.

Agonum scitulum, Dej. Spec. 3. 162 ; Icon. 2. 378. pl. 121. Ag. consimile, Steph. Mand. 1. 90, et Manual, p. 27.

Shining black, with a faint greenish tinge on the elytra. Head narrow, convex, with an oblong fovea on each side in front; tip of the mandibles pitchy, palpi and antennæ pitchy bläck. Thorax obeordate, sides rounded and widest rather before the middle, obliquely narrowed behind, posterior angles subrotundate, disk convex, dorsal furrow deeply impressed, base with a large oblong smooth fovea close to each hinder angle. Elytra oblong-ovate, slightly widening behind the middle, convex, finely striated, the third stria with from three to five faint punctures; legs pitchy black, femora slightly metallic. Length 3 lines.

This inseet is smaller and narrower than micans, and like the preceding species in colour except that it has a greenish tinge on the elytra. The head is narrower than in micans, the frontal 
impressions smaller; the thorax more obliquely sloped and narrowed behind, disk smoother, but the dorsal furrow deeper; the elytra also are much narrower.

There are two examples under the name consimile in the Stephensian collection.

17. A. micans : subaneo-virescens; thorace subquadrato, posticè subrotundato; elytris oblongo-ovatis, subtilitèr striatis, punctis tribus impressis; pedibus fusco-piceis.

Agonum micans, Nicolai, Col. Agr. Hal. 19. 7.-Steph. Mand. 1. 91, et Manual, p. 27.

Anchomenus micans, Erichson, Käfer, 115.

Carabus pelidnus, Dufts. Faun. 2. 144.

Agonum pelidnum, Sturm, D. F. 5. 194.-Dej. Spec. 3. 161 ;

Icon. 2. 377. pl. 121.-Heer, Faun. Helv. 63.

Ag. cursitor, Steph. Mand. 1. 91, et Manual, p. 27.

Oblong-ovate, obscure brassy green. Head smooth and shining, with a slight impression on each side in front; mandibles pitchy red, palpi and antennæ black, sometimes the base of the latter pitchy fuscous. Thorax subquadrate, delicately margined, sides rounded, rather narrowed behind and the posterior angles also somewhat rounded, each having a deep oblong impression. Elytra with the shoulders rounded and the sides nearly straight or very moderately dilated behind the middle, finely striated, having about three small punctures between the second and third striæ, also a series of larger impressions irregularly disposed along the margin; legs pitchy, tibiæ and tarsi pitchy fuscous. Length 3 lines.

Agonum cursitor, Kirby, corresponds with this species, which is rather a widely-distributed insect in marshes, damp woods and on river banks. "Dunston and on the banks of the Team, under the bark of willows, and in the decayed stems of thistles in moist ditches." Messrs. Hardy and Bold.

18. A. piceus : capite thoraceque nigris, hoc subquadrato, angulis posticis rotundatis; elytris oblongis levitèr striatis punctis quinque impressis pedibusque piceo-testaceis.

Carabus piceus, Linn. S. N. 2. 672.

C. picipes, Fab. S. EI. 1. 203.-Dufts. Faun. 2. 243.

Harpalus picipes, Gyll. Ins. Suec. 2. 151.

Agonum picipes, Sturm, D. F. 5. 196.-Dej. Spec. 3. 164 ;

Icon. 2. 381. pl. 122.-Steph. Mand. 1. 93, et Manual, p. 27.

Head and thorax black; mouth, palpi, and basal joint of the 
antennæ pitchy. Thorax subquadrate (Pl. II. f. 2), small and narrowish, sides very slightly rounded and not much narrower behind than in front, posterior angles rounded, disk depressed, transversely wrinkled, dorsal line entire, base with two deep smooth foveæ. Elytra wider than the thorax, much narrower than in the preceding species, oblong, shoulders rounded, the sides not dilated and rounded but almost purallel, moderately convex, very finely striated, with about five or six small punctures between the second and third striæ and also an interrupted series of small foveæ on the exterior margin; legs pitchy testaceous. Length 3 lines.

In its general habit this insect bears some resemblance to the preceding, but the elytra are narrower and more parallel and uniformly pitchy brown or fuscous, without any tinge of green. It cannot be confounded with pale pitchy examples of fuliginosus, because its form is wholly dissimilar, the thorax being considerably narrower and more quadrate, and the elytra also narrower and more parallel.

This is the Carabus piceus of Linnæus, and is so labelled in the Linnæan Collection. It is a somewhat local species, but abundant in damp woods, marshes, and on river banks in various parts of the kingdom.

19. A. pelidnus : nigro-piceus ; thorace oblongo, posticè coarctato, angulis posticis subrotundatis; elytris elongato-ovatis, striatis, striis subtilissimè crenulatis, punctis tribus vel quatuor impressis; pedibus rufo-piceis.

Carabus pelidnus, Payk. Faun. 1. 134.

Harpalus pelidnus, Gyll. Ins. Suec. 2. 150.

Agonum affine, Steph. Mand. 1. 94, et Manual, p. 28.

Elongate, narrow, deep pitchy black; mouth, tip of the mandibles, base of the palpi and basal joint of the antennæ rufous, the rest of the antennæ and of the palpi pitchy. Thorax oblong, widest in front, sides moderately rounded, much contracted behind, the posterior angles very little evident, disk very convex, much wrinkled transversely on each side the dorsal furrow, base with a smooth impunctate oblong impression near each angle. Elytra elongate, about twice the width of the thorax, shoulders rounded and a little elevated, the sides rather parallel or very slightly rounded till behind the middle and narrowed to the extremity, disk very convex, strongly striated, the striæ impunctate, but some of them appearing under a magnifying glass to be faintly crenulated, on the second stria near the apex there is a small impression and two others on the 
third before the middle, the exterior margin being also furnished with the usual series of fover; legs pitchy red. Length $3 \frac{1}{4}$ lines.

This species may immediately be distinguished from any of the preceding by its more elongate narrow form, in which respect it resembles Thoreyi, but independently of its dark colour it is rather larger, more convex, the elytra are more deeply striated, and the sides less parallel than in that insect. It is the true Carabus pelidnus of Paykull, and perfectly distinct from Ag. pelidnum, Steph., which corresponds with the next species. In the Stephensian cabinet it stands under the name Ag. affine, Steph.

It is apparently one of our rarest species, and I have met with but two indigenous examples; the one in the Stephensian cabinet above mentioned, captured near London; and the other in my own, for which I am indebted to Mr. F. Bates, of Leicester, who procured it from under a heap of "vegetable matter (principally Ranunculus aquaticus), raked out of Groby Pool, near Leicester, in June or July."

20. A. Thoreyi : capite thoraceque nigro-piceis, hoc oblongoovato, posticè coarctato, angulis posticis subrotundatis; elytris rufescentibus, elongatis, subparallelis, subtilitèr striatis, punctis tribus vel quatuor impressis; antennis basi pedibusque rufescentibus.

Agonum Thoreyi, Dej. Spec. 3. 165 ; Icon. 2. 382. pl. 122.

Ag. pelidnum, Steph. Mand. 1. 94, et Manual, p. 28.

Head black or pitchy black, smooth and convex; mouth, palpi and basal joint of the antennæ pitchy red, rest of the antennæ obscure. Thorax pitchy black with the margins often narrowly rufous, sometimes the disk pitchy rufous with the margins paler, oblong-ovate, narrow, sides a little rounded, contracted behind, posterior margins rounded so that the hinder angles are very slightly evident, disk very convex, having numerous transverse wrinkles on each side the dorsal furrow and a very slight stria near each hinder angle. Elytra rufescent, with an obscure dash in the middle next the suture, elongate, narrow, about twice the width of the thorax, shoulders rounded, sides very nearly straight, disk very moderately convex, finely striated, the third stria with two punctures and the second with one or two placed as in the preceding species; body beneath pitchy, with the thorax occasionally rufescent in less mature individuals; legs red with the joints pitchy. Length 3 lines.

This insect nearly resembles pelidnus, but it has always rufescent elytra ; it is also smaller; the elytra are less convex, more 
finely striated and their sides more parallel. It was formerly abundant in the fens about Whittlesea Mere and in Cambridgeshire. It has been taken by the Rev. W. Little at Raehills, Dumfriesshire.

21. A. quadripunctatus : nigrn-ceneus, thorace transverso, angulis posticis obtusis; elytris oblongo-ovatis, subtilitèr striatis, interstitio tertio foveolis quatuor impressis; pedibus nigris. (Pl. I. f. E.)

Carabus 4-punctatus, DeGeer, Ins.4.102.-Dufts. Faun.2. 146. Harpalus 4-punctatus, Gyll. Ins. Suec. 2. 159.

Agonum 4-punctatum, Sturm, D. F. 5.217.-Dej. Spec. 3. 176; Icon. 2. 384. pl. 122.

Anchomenus 4-punctatus, Erichson, Käfer, 112.

Agonum cupratum, Sturm, D. F. 5. 218.

This rare and remarkable species is smaller than any of the preceding. Head black, with a greenish tinge in the centre; mouth, palpi and antennæ black. Thorax greenish black or olivaceous, transverse, sides gradually rounded behind and with an elevated reflexed margin towards the posterior angles, disk convex, depressed towards the sides, base with two oblong foveæ. Elytra oblong-ovate, broader than the base of the thorax, with the shoulders rounded, dilated behind the middle, fincly striated, having four deep impressions between the second and third stria (rarely five) somewhat irregularly disposed, greenish or blackish green, shining; body beneath and legs black. Length $2 \frac{1}{2}$ lines.

The only British example I have seen was taken at Long Benton, by Mr. T. J. Bold, of Newcastle-on-Tyne, and it is recorded by him in his Catalogue of the Insects of Northumberland and Durham (p. 229).

\section{Genus 32. OLISTHOPUS, Dejean.}

Mentum dente medio nullo. Ligula apice truncata, paraglossis longior. Palpi articulo ultimo fusiformi, apice acuminato. Mandibulæ breves, rectiuscule. Labrum quadratum, apice truncatum. Tarsi antici maris articulis tribus dilatatis, unguiculi simplices.

1. O. rotundatus: fusco-aneus nitidus; thorace semiorbiculato; elytris oblongo-ovatis, striatis, striis obsoletè punctatis, interstitiis lavissimis, punctisque tribus impressis ; pedibus flavescentibus. 
Carabus rotundatus, Payk. Mon. 41.-Payk. Faun. 1. 136.

Harpalus rotundatus, Gyll. Ins. Suec. 2. 158.

Agonum rotundatum, Sturm, D. F. 5. 213.

Olisthopus rotundatus, Dej. Spec. 3.177 ; Icon.2.388. pl.123.-

Steph. Mand. 1. 96,,et Manual, p. 28.-Heer, Faun. Helv. 64.

Carabus rotundicollis, Marsham, Ent. 471.

Odontonyx rotundicollis, Steph. Mand. 1.96, et Manual, p. 28.

Brassy brown, very shining. Head convex, smooth, foveated between the antennæ, mouth, palpi and antennæ pitchy brown, some of the joints of the latter at the base yellow. Thorax broad and short, semi-orbicular, acutely margined, disk convex, transversely wrinkled, the dorsal furrow slight, base with two fover near the posterior angles, which together with the lateral margins are strongly punctured. Elytra oblong-ovate, rounded at the sides, rather narrowed at the apex, striated, the strix obsoletely punctured, interstices smooth and polished, having three deep impressions between the second and third striæ and the usual series on the external margin; legs pale yellow, with the underside of the body reddish pitchy. Length $3-3 \frac{1}{2}$ lines.

The difference between this insect and $O$. rotundicollis is imaginary. It is a very common species.

\section{Genus 33. PTEROSTICHUS, Bonelli.}

Mentum dente medio emarginato. Ligula apice truncata; paraglossis membranaceis, linearibus, ei aqualibus. Palpi articulo ultimo breviore, cylindrico, apice truncato. Mandibulæ mediocres, basi internè crenulata, acuta. Labrum quadratum, apice truncatum. Tarsi antici maris articulis tribus dilatatis, singulis obcordatis, subtùs biseriatim pectinatosetosis.

This genus is adopted to comprehend that group of insects to which Dejean assigned the name Feronia*, but which had been separated by Bonelli and others, under the names Pocilus, Pterostichus, Omaseus, Argutor, Steropus, Platysma, Abax, \&c., such divisions having been based chiefly upon certain external characters, which upon examination have not proved so invariableas to warrant their establishment as distinct genera. Redtenbacher divides them into two genera, Pccilus and Pterostichus, and among the latter

* The name Feronia cannot here be employed, because it had been proposed twenty years ago by Dr. Leach for a genus of Homalopterous Insects, and published with descriptive characters in the second volume of the Memoirs of the Wernerian Society.-J.F. Stephens. 
includes Argutor. Heer again maintains Argutor as a genus, on the ground of some slight variations in the mandibles and palpi, and assigns Prcilus, as well as Abax, Platysma and Omuseus, as subgenera to Pterostichus. Since, however, these distinctions appear to be unsatisfactory, seeing that the characters of some insects assigned to one group blend into those of others which are given to a different group, so as to render it extremely difficult to determine to which they really ought to belong, I have merely inserted the names in brackets, for the convenience of those English entomologists who may possibly be less familiar with the more generally received arrangement.

\section{(Pøcilus, Bonelli.)}

1. P. cupreus : alatus, oblongo-ovatus plerumque viridi-vel cupreo-aneus, nitidus; thorace transverso, posticè utrinque bistriato ; elytris striato-punctatis punctisque tribus posticè impressis; antennarum articulis duobus basi rufis.

Carabus cupreus, Linn. F. S. 801.-Fab. S. El. 1. 195.

Harpalus cupreus, Gyll. Ins. Suec. 2. 114.

Platysma cuprea, Sturm, D. F. 5. 94.

Feronia cuprea, Dej. Spec. 3. 207; Icon. 3. 12. pl. 126.

Pocilus cupreus, Steph. Mand. 1. 110, et Manual, p. 32.

Pterostichus cupreus, Erichson, Käfer,67.-Heer, Faun. Helv.68.

Var. b. Platysma versicolor, Sturm, D. F. 5. 99.

Precilus versicolor, Steph. Mand, 1. 110, et Manual, p. 32.

This species presents various shades of green, brassy green, brassy, coppery, purplish or black, very brilliant and shining. Head thickly and minutely punctured, having a fovea on each side, antennæ black, with two joints at the base red. Thorax narrowed in front, transverse, sides moderately rounded, broadly margined, posterior angles not quite complete right angles, disk convex in front, depressed on the sides and at the base, the latter punctured, having also two longitudinal foveæ on each side, the outer one shortest and close to the angle. Elytra oblong-ovate, slightly narrowed in front, sides a little rounded, deeply striated, the striæ finely punctured, the interstices convex, the third with three distinct impressed punctures behind; underside greenish black, thorax, breast and sides of the abdomen in front more or less punctured, legs black. Length $4 \frac{1}{2}-6$ lines.

$P$. versicolor is a rather smaller and narrower variety of this species, which is extremely common.

2. P. dimidiatus : alatus, oblongus ; capite thoraceque subquadrato posticè utrinque bistriato cupreis ; elytris viridibus, 
subparallelis, striato-punctatis; antennarum articulis duobus basi subtùs rufo-piceis.

Carabus dimidiatus, Oliv. Ent. 3. 35.-Fab. S. El. 1. 194.

Platysma dimidiata, Sturm, D. F. 5. 90.

Feronia dimidiata, Dej. Spec. 3. 213 ; Icon. 3. 16. pl. 126.

Pocilus dimidiatus, Steph. Mand. 1. 109, et Manual, p. 31.

Pterostichus dimidiatus, Erichson, Käfer, 68.-Heer, Faun.

Helv. 69.

Head and thorax more or less coppery, elytra rich green, sometimes black. Head with two deep striæ in front and otherwise wrinkled, eyes large and rather prominent, palpi and antennæ black, two joints at the base of the latter reddish beneath with a black line above. Thorax subquadrate, equally rounded at the sides, so that the width at the base about equals that of the anterior margin, posterior angles not quite rectangular, the disk all over transversely wrinkled, the dorsal furrow in front terminating in an elevated space, behind which there is a corresponding depression, the base rugose, having two longitudinal striæ on each side, the exterior one shortest. Elytra rather broader than the thorax, rounded at the shoulders but the sides very slightly rounded or somewhat straight, broadly margined, strongly punctate-striated, the third stria with three more deeply impressed punctures ; beneath black, sides of the thorax and of the abdomen in front punctured, legs black. Length $6 \frac{1}{2}$ lines.

It is a much larger insect than cupreus, and cannot be confounded with it. Like it, it is winged, but the head and eyes are larger, the fovex at the base of the thorax longer, especially the inner one which extends upwards considerably; the elytra are more oblong and their sides more parallel, the striæ conspicuously punctate, and the two joints at the base of the antennæ are red beneath only.

It is local, but may be taken abundantly on Hampstead Heath and Wandsworth Common; and at Folkstone in the spring. It is also found, as recorded by Mr. Stephens, at "Coombe Wood; Southend and in Norfolk."

3. P. lepidus : apterus, oblongus, plerumque cupreo-vel viridianeus, nitidus; thorace subquadrato, basi profundè bistriato ; elytris oblongis, striatis, striis obsoletissimè punctulatis, punctis tribus impressis; antennis pedibusque totis nigris.

Carabuslepidus, Fab. Mant. 1. 200 (1787).-Fab. S. El. 1. 189. -Payk. Mon. 32 (1790).

Harpalus lepidus, Gyll. Ins. Suec. 2. 94. 
Platysma lepida, Sturm, D. F. 5. 92.

Feronia lepida, Dej. Spec. 3. 218 ; Icon. 3. 21.pl. 127.

Pocilus lepidus, Steph. Mand. 1. 108, et Manual, p. 31.Ourtis, Ent. pl. 187.

Pterostichus lepidus, Erichson, Käfer, 67.-Heer, Faun. Helv. 70.

Wingless, narrower and more oblong than the preceding species, head and thorax brilliant shining greenish copper, purplish or greenish black, elytra also coppery or greenish brass, more rarely greenish or bluish black. Head convex behind, depressed in front of the antennæ, the frontal foveæ smaller, and the eyes less prominent than in dimidiatus, mandibles, palpi and antennæ wholly black. Thorax narrower, more quadrate, more finely margined, more contracted behind, more convex and smooth on the disk, the basal striæ more deeply impressed, the base smoother and the posterior angles more rectangular. Elytra oblong, rather contracted in front, sides very slightly rounded, strongly margined, disk rather flattish, moderately and less coarsely striated than in dimidiatus, the striæ so obsoletely punctulated as to be sometimes scarcely perceptible, the third with three impressions, interstices flattish; underside greenish black, sides of the breast and of the abdomen in front finely punctured, legs wholly black. Length 6 lines.

Rather a scarce species, but it has been taken sparingly in Norfolk, Devon and Hants; at Ely, Cambridge, Northampton, Hertford and Darenth Wood. It has on more than one occasion been found in some numbers at Charlton sand-pits in the spring, by breaking open the crevices in the rocks, in which they conceal themselves. "Tollcross, near Glasgow." Mr. Hislop.

\section{(Aваx, Bonelli.)}

4. P. striola : apterus, niger, depressus; thorace subquadrato, basi utrinque profundè bistriato, angulis posticis rectis; elytris profundè striatis, interstitiis planiusculis, lineâ laterali subcarinatâ.

Carabus striola, Fab. S. El. 1. 188.

Harpalus striola, Gyll. Ins. Suec. 2. 124.

Abax striola, Sturm, D. F. 4. 147.-Steph. Mand. 1. 125, et Manual, p. 35.

Feronia striola, Dej. Spec. 3. 378 ; Icon. 3. 151. pl. 148.

Pterostichus striola, Erichson, Käfer, 69.-Heer, Faun. Helv.79.

Wingless, broad, depressed, shining black. Head with an oblong fovea on each side between the eyes, and some elevated lines between them and the foveæ; antennæ with three joints 
at the base black and glabrous, the remainder fuscous and pubescent. Thorax subquadrate, narrowed in front, but nearly straight from about the middle to the hinder angles, which are right angles, the lateral margins incrassated, disk very strigose, with a strong dorsal furrow and two elongate very deeply impressed striæ on each side at the base. Elytra ovate, very broad, the breadth being slightly greater than that of the base of the thorax, humeral angles prominent, sides very slightly widest behind the middle, apex broadly rounded with the apical margin itself very slightly sinuated, deeply striated, having an elevated keel-shaped longitudinal ridge extending from the shoulders to about the middle of the seventh interstice, where it disappears, several of the interstices next the suture being elevated also at the extremity; legs incrassated, pitchy black, tibiæ and tarsi with red cilia. Length 8-9 lines.

Very common.

\section{(Pterostichus, Bonelli.)}

5. P. niger: oblongus, niger, subnitidus ; thorace quadrato, posticè utrinque levitèr impresso bistriatoque, angulis posticis rectis ; elytris profundè striatis, punctis tribus impressis.

Carabus niger, Ill. Käfer, 1. 182.-Fab. S. El. 1. 178.

Harpalus niger, Gyll. Ins. Suec. 2. 86.

Feronia nigra, Dej. Spec. 3. 337; Icon. 3. 108. pl. 142.

Platysma nigra, Steph. Mand. 1. 124, et Manual, p. 35.

Pterostichus niger, Erichson, Käfer, 70.-Heer, Faun. Helv. 81.

Oblong, black, slightly shining. Head with the usual foveæ between the antennæ, the latter with three joints at the base black and glabrous, the remainder fuscous and pubescent. Thorax quadrate, finely margined and the margins reflexed, slightly narrowed behind, posterior angles right angles, disk much wrinkled, depressed, with a deep dorsal furrow, base with a double impressed stria on each side. Elytra oblong, narrowest in front, dilated behind the middle, deeply striated, the striæ obsoletely punctate-crenate. $\delta$ with an elevated oblong tubercle on the last segment of the abdomen. Length 8-10 lines.

Common.

6. P. parumpunctatus : apterus, niger, nitidus; thorace quadrato, posticè angustato, basi utrinque profundè striato; elytris oblongo-ovatis, profundè striatis, interstitio tertio punctis tribus impressis.

Mas, abdominis segmento ultimo lineolâ acutè elevatâ. 
Germar, Spec. Nov. 19. 31 (1824).-Steph. Manual, p. 35.Heer, Faun. Helv. 72.

Feronia parumpunctata, Dej. Spec. 3. 342; Icon. 3. 112. pl. 142. Pterostichus brunnipes, Steph. Mand. 1. 121.

Wingless, shining black. Head with two transverse striæ in front and a slight fovea on each side behind them, apex of the palpi and of the antennæ ferruginous red. Thorax quadrate, anterior angles prominent, sides rounded and dilated in front, much narrowed behind, the margins reflexed, the hinder angles rectangular with their apex slightly obtuse, disk with a very deeply impressed dorsal furrow and a profound stria on each side at the base, exterior to which is a small ovate impression close to the angle. Elytra oblong-ovate, shoulders rounded, deeply striated, interstices rather coarsely elevated, with three impressions on the third; $\delta$ with a longitudinal acutely-elevated ridge on the last segment of the abdomen. Length 7-8 lines.

"Local, but abundant at Newcastle, Benwell, Ouseburn Dene, Long Benton, Dunston, Ravensworth, Gateshead Fell, \&c.," in spring and autumn. Hardy and Bold's Catalogue.

\section{(Platysma, Bonelli.)}

7. P. oblongo-punctatus : alatus, obscurè æneus; thorace quadrato, posticè angustato, basi utrinque unistriato, angulis posticis acutiusculis ; elytris ovatis, striatis, foveolis quinque impressis ; palpis, tibiis tarsisque rufo-piceis.

Carabus oblongo-punctatus, Fab. Mant. 1. 202 (1787).-Fab. S. El. 1. 183.-Payk. Mon. 55 (1790).

Harpalus oblongo-punctatus, Gyll. Ins. Suec. 2. 85.

Platysma oblongo-punctata, Sturm, D. F. 5. 51.

Feronia oblongo-punctata, Dej. Spec. 3.316; Icon. 3. 99. pl. 140. Pterostichus oblongo-punctatus, Steph.Mand.1.122, et Manual, p. 35.-Erichson, Käfer, 76.-Heer, Faun. Helv. 71.

Winged, obscure brassy black. Head smooth and shining, with a faintly impressed fovea on each side in front connected by a transverse stria, antennæ black, palpi red. Thorax quadrate, the length being fully equal to the breadth in front, the anterior margin curved inwards in the middle considerably, so that the anterior angles are very prominent, sides rounded from the angles to behind the middle, then much contracted till just before the posterior angles, before which they become produced, so as to form, with the base, a little acute angle, the base itself being nearly straight, disk transversely wrinkled, dorsal furrow abbreviated in front and terminating in a curved stria, rather deeper behind just before it reaches the base, the latter much 
depressed, punctured on each side, and with a large punctured fovea terminating in an oblong stria about midway between the dorsal furrow and the exterior margin. Elytra broad, short, widest behind the middle, apex considerably narrowed, moderately striated, having from three to five large impressions irregularly disposed on or near the third interstice; beneath black, femora pitchy, tibiæ and tarsi reddish. Length $5 \frac{1}{2}-6$ lines.

At first sight this species appears to resemble Orinomus, but its characters are wholly dissimilar. The thorax is much longer and therefore more quadrate, the base more truncate, the posterior angles less elevated and more acute, the base more depressed and the basal impression extends more considerably upwards; the form and sculpture of the elytra also are equally dissimilar.

Local. Bagley Wood, Oxon; Harleston Woods, near Northampton, under chips of pine bark in abundance; Windsor; Devonshire, \&c. Found also in Ireland.

\section{(Adelosia, Stephens.)}

8. P. picimanus : alatus, nigro-piceus, depressus; thorace cordato, posticè coarctato, utrinque unistriato; elytris oblongis, subparallelis, punctato-striatis, punctis tribus impressis, antennis pedibusque rufis.

Carabus picimanus, Dufts. Faun. 2. 159.

Platysma picimana, Sturm, D. F. 5. 48.

Feronia picimana, Dej. Spec. 3. 310 ; Icon. 3. 87. pl. 138.

Pterostichus macer, Steph. Mand. 1. 123.

Adelosia picea, Steph. Manual, p. 35.

Winged, depressed, pitchy black or pitchy red, shining. Head large, with a slight fovea on each side between the antennæ, three joints of the latter smooth, the upper ones fuscous and pubescent. Thorax cordate, much contracted behind, but the posterior angles rectangular, often rusty red, the dorsal furrow strongly impressed, the base with two oblong smooth striæ. Elytra oblong, the shoulders rounded, the sides almost parallel, but a little waved before the middle, rounded and not narrowed at the apex, disk rather depressed, finely punctate-striated, the third stria with three deep impressions, one before the middle, another a little bchind the middle and the third at the extremity; underside and legs rusty red. Length 6 lines.

If piceus be Olivier's name for this insect, the more generally received one (picimanus) ought to stand, because the former had 
previously been employed by Linnæus to represent a different species of Carabus.

This is rather a local species. "Hackney Marshes, Battersea Fields, and near Southend;" "Common on the banks of the Tees," are the localities given by Mr. Stephens. I have found it not very commonly in the Isle of Wight. "Near Dublin by J. Tardy." A. H. Haliday, Esq.

\section{(Steropus, Megerle.)}

9. P. madidus: apterus, niger, nitidus; thorace subrotundato, posticè utrinque foveolato; elytris ovatis, striatis, puncto posticè impressis; pedibus nigris vel rufis.

Mas, abdominis segmento ultimo obtusè dentato.

Carabus madidus, Fab. Mant. 1. 199.-Fab. S. El. 1. 181.

Platysma madida, Sturm, D. F. 2. 49. pl. 112.

Feronia madida, Dej. Spec. 3. 294 ; Icon. 3. 79. pl. 136.

Steropus madidus, Steph. Mand. 1. 117, et Manual, p. 33.

S. arrogans, Steph. Mand. 5. 376, et Manual, p. 33.

Wingless, shining black, sometimes slightly brassy, palpi red, apex of the antennæ testaceous. Thorax quadrate, slightly rounded at the sides and narrowed a little behind, but again rounded at the posterior angles, disk convex, smooth, or slightly wrinkled, the dorsal line strongly impressed, the base with a broad rugged fovea close to each angle. Elytra ovate, convex, striated, the striæ obsoletely punctured, the third interstice with a deep puncture a little before the extremity ; underside black, legs sometimes black, sometimes entirely red; last segment of the abdomen in the $\delta$ armed with an obtuse tooth. Length 7-8 lines.

Steropus arrogans, Steph., does not differ from this species. Carabus arrogans, Dufts. (Feronia Gagatina, Dej.) is a considerably larger insect, which is found in Spain, but neither in France nor Britain. This species is very common in England, Scotland and Ireland.

10. P. Athiops : apterus, niger, nitidus; thorace subrotundato, basi utrinque foveolato, angulis posticis rotundatis; elytris ovatis, striatis, punctis tribus impressis.

Mas, abdominis segmento penultimo dentato.

Carabus AEthiops, Panz. Faun. 37. 22.-IIl. Käfer, 1. 161.

Pterostichus AEthiops, Sturm, D. F.5.31.-Heer, Faun. Helv.84. Feronia AEthiops, Dej. Spec. 3. 298 ; Icon. 3. 84. pl. 137.

Steropus Athiops, Steph. Mand. 1. 117, et Manual, p. 33. 
S. concinnus, Curtis, Ent. pl. 171.

S. cognatus, Steph. Mand. 5. 377, et Manual, p. 33.

Considerably smaller than madidus, wingless, deep shining black. Head with a transverse impression in front and two small foveæ placed further back than in maditus, tip of the palpi red. Thorax rotundate at the sides, narrowed and very much rounded behind at the angles, dorsal furrow entire, base with two deep foveæ. Elytra more ovate and shorter than in madidus, rather narrowed in front and rounded at the shoulders, sides also rounded and widest behind the middle and not narrowed at the apex, only very slightly sinuated, convex, deeply striated, the striæ impunctate, the third interstice with three punctures and the margin with the usual series; underside shining black, the penultimate segment of the abdomen of the $\delta$ armed with an obtuse tooth. Length $5 \frac{1}{2}$ lines.

This insect is found in the mountainous districts of the North of England, Wales and Scotland. Abundant on the Snowdon range, in August 1847. S. cognatus, Steph., does not differ from it.

\section{(Omaseus, Ziegler.)}

11. P. aterrimus : alatus, ater, nitidus; thorace transverso, posticè utrinque foveolato, angulis posticis subrotundatis; elytris oblongis, subparallelis, lævigatis, subtilissimè punctato-striatis, profundè trifoveolatis.

Carabus aterrimus, Payk. Mon. 127 (1790).-Fab. S. El. 1. 198 (1801).

Harpalus aterrimus, Gyll. Ins. Suec. 2. 153.

Platysma aterrima, Sturm, D. F. 5. 29.

Feronia aterrima, Dej. Spec. 3. 290 ; Icon. 3. 75. pl. 135.

Omaseus aterrimus, Curtis, Ent. pl. 15.-Steph. Mand. 1. 113, et Manual, p. 32.

Pterostichus aterrimus, Erichson, Käfer, 75.

Winged, black, smooth and shining. Head with a ridge in front on which are two small foveæ, and behind it an oblong fovea on each side, apex of the antennæ fuscous black and slightly pubescent. Thorax transverse or subquadrate, narrowed and rounded behind, the lateral margins broadly reflexed, especially at the posterior angles, disk convex on each side the dorsal furrow, which is interrupted in front by a deep depression, and anterior to that there is a corresponding elevation, base depressed, having on each side a large punctured fovea close to the angles. Elytra oblong, broader than the thorax, not narrowed in front, only the humeral angles a little rounded, sides very nearly straight, apex rounded, disk convex, finely striated, 
the strix obsoletely punctate, the second with two large impressions, one about the middle, the other further behind, the third stria with one impression in advance of the former, sometimes these impressions are on the third interstice, all the interstices very smooth and glabrous, the striæ in the $q$ are much fainter, sometimes almost obsolete, the margin has a continuous series of punctures; the underside and legs black. Length $6 \frac{1}{2}$ lines.

Very local: plentiful in the fens about Whittlesea Mere; Bottisham and the Cambridgeshire marshes; Horning Fen, Norfolk, \&c. Mr. Clear has taken it also in the neighbourhood of Cork.

12. P. Orinomus : alatus, obscurè æneo-niger, nitidus ; thorace subquadrato, posticè subangustato, utrinque parcè punctato foveolato, angulis posticis acutiusculis; elytris oblongoovatis, striatis, striis obsoletissimè punctatis, foveis quinque disco impressis.

Omaseus Orinomum, Steph. Mand. 1. 114, et Manual, p. 32.

O. Bulwerii, Steph. Mand. 1. 1]4, et Manual, p. 32 .

Winged, deep shining black, more or less metallic in the $\delta$, dull black in the $q$. Head with a transverse band in front bearing foveæ and two larger oblong foveæ behind it, antennæ brownish black and pubescent at the apex. Thorax subquadrate, but in some examples rather more nearly quadrate than in others, sides rounded below the anterior angles, narrowed behind, moderately margined, posterior angles rather acute, disk transversely wrinkled with an impressed dorsal furrow abbreviated in front and terminating in a depression, base with a deep punctured fovea on each side. Elytra oblong-ovate, rounded at the shoulders, thence slightly and gradually rounded and widening till behind the middle, obliquely sinuated and narrowed at the apex, finely striated, the striæ sometimes obsoletely punctured, especially on the sides, interstices convex in the $\delta$, flatter in the $q$, with five or six deep impressions irregularly placed on or near the third from the suture. Length 5 lines.

The variety $O$. Bulwerii has a more brassy surface and is found in Ireland.

Locally distributed in the mountainous districts of the North of England, Wales and Scotland. Near Hebden Bridge, \&c., Yorkshire; on the high moors near Llangollen, and on the left of the Ruthin road in July and August. "Langley Common, and on the summit of Hedgehope in June." Messrs. Hardy and Bold. 
13. P. melanarius : oblongus, niger ; thorace subquadrato, posticè subangustato, utrinque foveolato bistriato, angulis posticis obtusis ; elytris profundè striatis, interstitiis convexiusculis.

Carabus melanarius, Ill. Käfer, 1. 163.

Harpalus melanarius, Gyll. Ins. Suec. 2. 92.

Feronia melanaria, Dej. Spec. 3. 271 ; Icon. 3. 66. pl. 133.

Omaseus melanarius, Steph. Mand. 1. 115, et Manual, p. 33.

O. affinis, Steph. Mand. 1. 116.

O. sulcatus, Steph. Mand. 5. 376, et Manual, p. 33.

Carabus leucophthalmus, Fab. S. El. 1. 177.

Deep black, shining. Head with the usual impressed fovea on each side between the eyes very strongly marked. Thorax subquadrate, the breadth in front being greater than the length, the sides obliquely narrowed behind the middle, the posterior angles small and prominent, but the apex of the angle itself obtuse, disk much wrinkled, dorsal furrow entire and more deeply impressed at the base, the latter impunctate, but with two deep rough foveæ terminating in a longitudinal stria and exterior to these with an elevated fold running into the angle. Elytra broader than the thorax, and furthermore dilated behind the middle, convex, deeply striated, the second stria from the suture with two deep impressions, one about the middle and the other two-thirds the distance between that and the apex. Length $6 \frac{1}{2}-9$ lines.

Although this insect is the C. vulgaris of the Linnæean Collection as shown by the major part of the examples placed there under that name, it cannot be the species intended by Linnæus to represent his $C$. vulgaris, because he expressly describes the latter as nigro-aneus. It must consequently continue to bear the name assigned to it by Illiger:

The insects recorded under the names $O$. affinis and sulcatus in the Stephensian cabinet evidently belong to the present species. The former is a very large example, and the latter a somewhat small mountain variety which is abundant in North Wales.

Common.

14. P. nigrita: oblongus, niger ; thorace subquadrato, posticè subangustato, utrinque punctulato foveolato bistriatoque, angulis posticis obtusiusculis; elytris striatis, interstitiis planiusculis.

Mas, abdominis segmento ultimo tuberculato. 
Carabus nigrita, Fab. Ent. S. 1. 158.-Fab. S. El. 1. 200.

Harpalus nigrita, Gyll. Ins. Suec. 2. 88.

Feronia nigrita, Dej. Spec. 3. 284 ; Icon. 3. 68. pl. 134.

Omaseus nigrita, Steph. Mand. 1. 114, et Manual, p. 32.

O. rufo-femoratus, Steph. Mand. 1. 115, et Manual, p. 33.

Pterostichus nigrita, Erichson, Käfer, 71.

Winged, shining black. Head smooth, with an oblong wrinkled fovea on each side. Thorax subquadrate, sides rather rounded, narrowed behind, posterior angles obtuse, each with a deep bilobed punctured fovea. Elytra oblong, deeply striated, the striæ occasionally very faintly punctured, having also three deeper impressions between the second and third striæ; abdomen of the $\delta$ with a small tubercle on the last segment. Length $4 \frac{1}{2}-5$ lines.

O. rufofemoratus, Steph., is a variety of this very common species.

15. P. anthracinus : oblongus, niger; thorace subquadrato, basi utrinque punctulato foveolato bistriatoque, angulis posticis acutiusculis; elytris oblongis, subparallelis, striatis, interstitiis planis, summo apice ad suturam denticulo prominulo armatis.

Mas, abdominis segmento ultimo profundè foveolato.

Carabus anthracinus, Ill. Käfer, 1. 181.

Harpalus anthracinus, Gyll. Ins. Suec. 4. 425.

Feronia anthracina, Dej. Spec. 3. 286 ; Icon. 3. 69. pl. 134.

Omaseus anthracinus, Steph. Manual, p. 33.

More oblong than nigrita. Thorax longer, the sides straighter and the base more truncate, the posterior angles more acute, the basal foveæ larger and more densely punctured. Elytra more elongate, less narrowed in front, sides more parallel, armed at the extreme tip next the suture with a minute denticulation, a character which distinguishes it in both sexes from nigrita; and the $\delta$ has furthermore a large fovea on the last segment of the abdomen beneath. Length 5 lines.

Not uncommon in marshes; abundant at Whittlesea Mere and at Herringstone, Dorset; also within the London district, at Hammersmith, Battersea fields, \&c. It is found likewise in the north of England and in Ireland.

16. P. gracilis : oblongus, niger; thorace subquadrato, posticè utrinque punctato foveolato; elytris oblongis, striatis, striis obsoletè punctatis ; antennis pedibusque piceis. Abdominis segmento ultimo in utroque sexu lævigato. 
Feronia gracilis, Dej. Spec. 3. 287 ; Icon. 3. 71. pl. 135.

Pterostichus gracilis, Erichson, Käfer, 72.-Heer, Faun. Helv. 83.

Omaseus tetricus, Haliday, Curtis, 2nd ed. f. 15.-Steph. Manual, p. 33.

O. rotundicollis, Steph. Mand. 5. 376, et Manual, p. 33.

Shining black, apex of the antennæ and of the palpi testaceous, and the base of some of the joints pitchy red. Thorax subquadrate, a little narrowed behind, the sides acutely margined, the hinder angles right angles and a little prominent, the base with a very large rugose fovea on each side terminating as usual in two striæ. Elytra rather parallel, striated, the striæ obsoletely punctured, with three deeper impressions on the third interstice, two of them near the second stria and one near the third; abdomen beneath smooth in both sexes, the rudiments only of a raised line being discernible under a magnifying glass on the last segment, each segment having two punctures placed equidistant from each other so as to form two parallel lines of punctures; legs pitchy red, middle of the femora darkest. Length 4 lines.

The species is not common; Mr. Haliday captured it near Belfast. I have taken it in the marshes near Whittlesea Mere and at Herringstone near Dorchester in May and June, and in Hammersmith marshes, not unfrequently among refuse or under stones. The examples in the Stephensian cabinet which stand under the name rotundicollis belong to this species, and are stated to have been captured near London.

17. P. minor : alatus, niger; thorace subquadrato, posticè utrinque punctulato bistriatoque; elytris oblongis, striatis, striis subtilitèr punctatis ; antennis pedibusque rufo-piceis. Mas, abdominis segmento ultimo lineolâ elevatâ ornato.

Harpalus minor, Sahl. Ins. Fenn. 221.-Gyll. Ins. Suec. 4. 426. Feronia minor, Dej. Spec. 3. 287 ; Icon. 3. 71. pl. 135.

Pterostichus minor, Erichson, Käfer, 72.-Heer, Faun. Helv. 83. Harpalus anthracinus, Gyll. Ins. Suec. 2. 89.

Argutor anthracinus, Steph. Mand. 1. 105, et Manual, p. 31. Omaseus lavigatus, Steph. Mand. 1. 115, et Manual, p. 32.

Winged, black or pitchy black, mouth, palpi and antennæ pitchy red, base of the latter dusky ferruginous. Thorax subquadrate, sometimes entirely quadrate, rather narrowed behind, posterior angles right angles, the dorsal furrow more deeply impressed before and behind, the base with two foveæ much punctulated, the space between them being in some examples smooth, in others very much punctured, and the size of the foveæ varies 
in different individuals, in some assuming the form of an oblong impression, in others expanding considerably. Elytra oblong, narrow, sides rather parallel, striated, the striæ faintly punctured, having three larger impressions on the third interstice and the usual series on the margin; body beneath smooth with the sides of the breast alone punctured, tip of the abdomen testaceous red, and furnished with a slightly elevated longitudinal line in the $\delta$; legs pitchy red. Length $3 \frac{1}{4}$ lines.

Argutor anthracinus and Omaseus lavigatus, Steph., both belong to this species. It is found in marshy places, but is rather local. I have taken it plentifully in the Eridge Woods near Tunbridge Wells and in the Huntingdonshire and Cambridgeshire fens ; it is abundant on the edges of Whittlesea Mere both in spring and autumn. Mr. Haliday captured it also in Ireland.

\section{(Argutor, Megerle.)}

18. P. vernalis: alatus, niger, nitidus; thorace subquadrato, posticè utrinque punctato unistriatoque, angulis posticis subrectis ; elytris oblongis, subparallelis, fortitèr striatis, striis obsoletè punctatis; antennis pedibusque piceis.

Harpalus vernalis, Gyll. Ins. Suec. 2. 90.

Feronia vernalis, Dej. Spec. 3. 240 ; Icon. 3. 32. pl. 129.

Argutor vernalis, Steph. Mand. 1. 103, et Manual, p. 30.

Platysma crenata, Sturm, D. F. 5. 73.

Argutor rufomarginatus, Curtis, Ent. pl. 666.

A. inquinatus, Steph. Mand. 1. 103, et Manual, p. 30.

Winged, black and shining. Head smooth, with two transverse striæ in front, palpi and antennæ pitchy black, base of the latter pitchy red. Thorax subquadrate, sides very moderately and equally rounded, so that the width before and behind is nearly the same, posterior angles minute at the tip and not quite right angles, disk convex, dorsal furrow very slight, base impunctate in the middle, but strongly punctured on both sides, having also an oblong impression or stria in the midst of a wide shallow fovea in which the punctures are contained close to the hinder angles. Elytra wide, oblong, sides almost parallel, apex rounded, deeply striated, the striæ finely punctured, the third interstice with three more distinct impressions, the base without the short stria next the scutellum; sides of the breast strongly punctured, legs pitchy black. Length 3 lines.

A. inquinatus, Steph., is identical with this insect, of which also $A$. rufomarginatus, Curtis, is an immature example. It is a very abundant species in marshy places, on the banks of rivers, \&.c., throughout the kingdom. 
19. P. inæqualis : nigro-piceus, nitidus; thorace oblongo subquadrato, posticè punctulato utrinque foveolato, angulis posticis rectis; elytris oblongis, striatis, striis subtiliter crenulatis; antennis pedibusque rufescentibus.

Carabus inaqualis, Marsham, Ent. 456.

Argutor incequalis, Steph. Mand. 1. 103, et Manual, p. 30.

Carabus.Scalesii, Marsham, Steph. Mand. 1. 103, et Manual, p. 30.

C. longicollis, Dufts. Faun. 2. 180.

Argutor longicollis, Steph. Mand. 1. 104, et Manual, p. 30.Curtis, Ent. pl. 666.

Feronia negligens, Dej. Spec. 3. 249 ; Icon. 3. 35. pl. 129.

Smaller and less convex than the preceding, pitchy black, sometimes pitchy ferruginous, shining. Head very small and narrow, palpi and antennæ red. Thorax oblong, broad in front and much rounded below the anterior angles and dilated in the middle, from thence narrowed towards the base, just before which it becomes straight and with the posterior margin forms a right angle, disk very smooth and glossy on each side the dorsal furrow, which is entire and is met in front by a slight curved transverse stria, the entire base together with two oblong impressions midway between the dorsal furrow and the hinder angle closely punctured. Elytra oblong, sides nearly straight, not at all dilated behind the middle, the entire surface equally and regularly striated, the striæ finely crenulated, sometimes with one or more punctures on the third interstice, the base without the short stria next the scutellum; the whole underside thickly punctured, legs red. Length $2 \frac{3}{4}$ lines.

Abundant on the coast at Cowes, Ryde and Sandown, Isle of Wight ; Herne Bay; Gravesend; "Southend and among rejectamenta of the Irwell and Stirling." Also common in damp woods near Tunbridge Wells and Newark.

20. P. erythropus : nigro-piceus, nitidus; thorace subcordato, posticè punctato, utrinque striato, angulis posticis acutis; elytris oblongo-ovatis, punctato-striatis ; antennis pedibusque rufo-piceis.

Carabus erythropus, Marsham, Ent. 461.

Argutor erythropus, Steph. Mand. 1. 105, et Manual, p. 31.

Harpalus pygmaeus, Sturm, D. F. 4. 114.

H. strenuus, Gyll. Ins. Suec. 4. 428.

Feronia strenua, Dej. Spec. 3. 252 ; Icon. 3. 39. pl. 130.

Argutor interstinctus, Steph. Mand. 1. 104, et Manual, p. 30.

Pitchy black, shining, palpi and antennæ red, sometimes pitchy. 
Thorax subcordate, sides very much rounded and dilated in front, contracted behind, posterior angles acute, the entire base distinctly punctured and with an oblong punctured impression or narrow fovea on each side. Elytra oblong-ovate, much wider than the thorax, shoulders regularly rounded, sides very gradually widening and rounded about the middle, then insensibly narrowed again and the apex rounded, the disk convex, strongly striated, the striæ most distinctly punctured, the outer striæ less deeply punctured and less profoundly impressed than the others; the underside of the thorax punctured on the sides, legs red, sometimes pitchy. Length 3 lines.

The principal characters which distinguish this insect from strenuus, which it so nearly resembles as to be constantly confounded with it, consist in the distinct punctuation at the base of the thorax and its more rotundate form in front, the wider and more oval form of the elytra and its more deeply punctured striæ.

This species is rather scarce. Stephens remarks that it is "common in the London districts, in Scotland, \&c.," but that observation must be considered applicable rather to the next species, which he appears to have confounded with it, the two species being mixed up in his collection, though the description given is to be referred to the present insect. The species recorded by him as interstinctus is identical with it, and its localities given are "Hertford and Southend in the spring." I have taken it in Eridge Woods near Tunbridge Wells in the autumn, and a black variety near Hebden Bridge and in the neighbourhood of Newark.

21. P. strenuus: nigro-piceus, nitidus; thorace subquadrato, posticè utrinque striato, angulis posticis acutiusculis ; elytris striatis, striis subtilissimè punctatis; antennis pedibusque rufo-piceis.

Carabus strenuus, Panz. Faun. 38.-Ill. Käfer, 1. 185.

Argutor strenuus, Steph. Mand. 1. 105, et Manual, p. 30.Heer, Faun. Helv. 66.

Pterostichus strenuus, Erichson, Käfer, 74.

Harpalus pullus, Gyll. Ins. Suec. 4. 429.

Feronia pulla, Dej. Spec. 3. 254 ; Icos. 3. 41.pl. 130. Argutor pullus, Steph. Mand. 1. 105, et Manual, p. 31. A. diligens, Steph. Mand. 1. 104, et Manual, p. 30.

This insect closely resembles erythropus, but is usually rather smaller and narrower. The thorax is less dilated at the sides and more gradually contracted behind, the posterior angles being also a little more acute and prominent; the base of the thorax is 
either not at all punctured, or in some individuals presents a very slight punctuntion; the elytra are less wide and the sides less rounded, the entire disk is very equally striated, but the striæ most obsoletely punctured, the inner striæ being as delicately marked as the outer three; underside smooth; legs red, sometimes in darker individuals pitchy black. Length $2 \frac{3}{4}$ lines.

This insect is extremely common everywhere and is generally known among us as erythropus, but I have assigned that name to the preceding species on the ground of Marsham's description, "Elytra profundiusculè striata, in striis punctula plurima conspicienda." There is a variety of this also as well as of the preceding which is entirely shining black, including the antennæ and legs.

\section{(Platyderus, Stephens.)}

22. P. ruficollis : apterus, rufo-piceus; thorace rufescente, oblongo-quadrato posticè utrinque unistriato, angulis posticis obtusiusculis; elytris elongatis, subparallelis, striatis, punctisque tribus impressis; antennis pedibusque rufis.

Carabus ruficollis, Marsham, Ent. 456.

Platyderus ruficollis, Steph. Mand. 1. 101, et Manual, p. 30.

Feronia depressa, Dej. Spec. 3. 258 ; Icon. 3. 46. pl. 131.

Argutor depressus, Heer, Faun. Helv. 66.

Wingless, elongate, depressed, pitchy or ferruginous. Head pitchy, very smooth and shining, flattened in front and having a transverse stria between the antennæ, very convex behind; palpi and antennæ rusty red. Thorax oblong-quadrate, the anterior angles prominent, and below them the sides regularly and moderately curved, narrowed behind, posterior angles obtuse, rufescent, very smooth and glossy, having a deep dorsal furrow and a strongly impressed impunctate stria on each side at the base about midway between the dorsal furrow and the lateral margin, the base itself being also smooth and impunctate. Elytra elongate, rather wider than the thorax, rounded at the shoulders, but with the sides somewhat parallel, narrowed however at the apex, pitchy ferruginous, rather flattish, evenly and smoothly striated, the striæ impunctate, with three impressions on the third from the suture and a series on the exterior margin ; underside smooth, legs red. Length $3 \frac{1}{4}$ lines.

The colour varies, probably according to maturity; sometimes the elytra are ferruginous red, in other individuals pitchy with their base slightly rufous, but the thorax is always rufescent. This insect was first described by Marsham under the name which I have retained for it in right of priority. It is better known on 
the continent as Feronia depressa, Dej., and is apparently everywhere uncommon.

Stephens states that it is found under moss at the roots of trees in Richmond Park. "Scarce beneath loose cinders and stones on the coast at South Shields in April and May." $T . J$. Bold. I have found it under stones by the road-side between Folkstone and Sandgate in May rather plentifully.

\section{Genus 34. STOMIS, Clairville.}

Mentum dente medio integro. Ligula apice obtusa; paraglossis membranaceis, linearibus, eam longè superantibus. Palpi articulo ultimo subfusiformi, apice truncato, penultimo subaquali. Mandibulæ elongate, porrecte. Labrum breve, emarginatum. Tarsi antici muris articulis tribus dilatatis, subtùs biseriatìm pectinato-setosis.

1. S. pumicatus : nigro-piceus, nitidus; thorace elongato cordato, posticè coarctato utrinque unistriato punctulatoque; elytris oblongis, punctato-striatis, antennis pedibusque rufis.

Carabus pumicatus, Panz. Faun. 30. 16.

Stomis pumicatus, Clairv. Ent. Helv. 2.49. - Sturm, D. F. 6.4.Dej. Spec. 3. 435 ; Icon. 3. 207. pl. 156.-Steph. Mand. 1. 118, et Manual, p. 34.-Erichson, Käfer, 76.-Heer, Faun. Helv. 64.

Harpalus pumicatus, Gyll. Ins. Suec. 3. 693.

Elongate, wingless, pitchy black, shining. Head narrow, smooth, with a small impression in the centre of the crown and a slight punctured fovea on each side, palpi and antennæ red. Thorax elongate cordate, sides very much rounded and dilated below the anterior angles, much contracted behind, posterior angles rather elevated, small and acute, disk convex, the dorsal line bordered by a few punctures, the base with an even transverse depression and an oblong striated fovea on each side of it. Elytra elongate ovate, having the shoulders narrowed and rounded, punctate-striated and somewhat crenulated; underside of the thorax, breast and sides of the abdomen punctured, legs red. Length 3 lines.

Not uncommon beneath stones in England, Scotland and lreland, though apparently nowhere abundant.

\section{Genus 35. BROsCUS, Panzer.}

Mentum dente medio integro. Ligula apice truncata; paraglossis membranaceis, apice rotundatis, ei aqualibus. Palpi articulo 
ultimo subcylindrico, apice truncato; maxillares articulo ultimo penultimo aquali, labiales eo breviore. Mandibulæ valida, inermes. Labrum truncatum. Tarsi antici maris articulis dilatatis, primo elongato triangulari, secundo tertioque breviter obcordatis.

1. B. cephalotes : ater, opacus ; thorace cordato, posticè coarctato ; elytris elongatis, subparallelis, subtilissimè punctatostriatis.

Carabus cephalotes, Linn. F. S. 788.-Fab. S. El. 1. 187. Harpalus cephalotes, Clairv. Ent. Helv. 2. 71.-Gyll. Ins. Suec. 2. 147.

Broscus cephalotes, Sturm, D. F. 4. 141.-Steph. Mand. 1. 118, et Manual, p. 34.

Cephalotes vulgaris, Dej. Spec. 3. 428 ; Icon. 3. 203. pl. 155. -Erichson, Käfer, 77.-Heer, Faun. Helv. 19.

Elongate, opake black. Head sparingly punctured and strigose, with two broad punctured foveæ between the antennæ, the latter black, with some of the upper joints fuscous testaceous. Thorax cordate, very much contracted behind, very convex, with the usual central line and the disk transversely wrinkled, the base coarsely punctured; scutellum semirotundate, with an impression on each side. Elytra elongate, shoulders rounded, sides somewhat parallel, but slightly widest behind the middle, convex, very faintly punctate-striate, with seven or eight small remote punctures near the outer margin; legs elongate, anterior tibiæ armed with two long spines, one at the apex and the other about the middle. Length 8-10 lines.

The generic name Cephalotes, Bonelli, is now commonly received on the Continent to represent a group of five remarkable insects, two only of which occur in Europe. The species before us is the most commonly known, and stands as Cephalotes vulgaris, Bonelli ; but Panzer's name Broscus claims rather the priority, and the specific name vulgaris had already been employed.

This insect is very abundant, burrowing under stones and marine rejectamenta, on many of the sandy coasts of England, Scotland and Ireland; it is not, however, as has been commonly supposed, exclusively a coast species, for it has been taken by T. V. Wollaston, Esq. on a sandy common near Twigmoor, in the north of Lincolnshire, forty miles from the sea; and I myself have captured specimens near Woburn, in Bedfordshire, more than double that distance from the coast. 
Genus 36. MISCODERA, Eschscholtz.

Mentum dente medio minimo, obtuso. Ligula obtusa; paraglossis membranaceis, ei aqualibus. Palpi articulo ultimo subcylindrico, truncato. Mandibulæ acuta, unidentata. Labrum quadratum, truncatum. Tarsi antici maris articulis tribus dilatatis.

1. M. arctica : anea nitidissima; thorace subgloboso, posticè coarctato; elytris ovatis, dorso obsoletè punctato-striatis ; antennis pedibusque rufis.

Scarites arcticus, Payk. Faun. 1. 85.

Clivina arctica, Gyll. Ins. Suec. 2. 168.-Dej. Spec. 1. 420; Icon. 1. 21\% pl. 23.

Miscodera arctica, Steph. Mand. 1. 377, et Manual, p. 34.

Leiochiton Readii, Curtis, Ent. pl. 346.

L. arcticum, Heer, Faun. Helv. 19.

Variable in colour, usually brownish brass, sometimes greenish or bluish black. Head smooth, with a transverse ridge in front and an impression on each side, palpi and antennæ red. Thorax truncate in front, sides very much rounded and dilated before the middle and contracted behind, globose and shining, with a slight dorsal line, but without basal foveæ, base with a narrow depresed neck remote from the elytra, and furnished with a few punctures on the sides. Elytra ovate, with the shoulders rounded, dilated behind the middle, very convex and shining, having a few irregular more or less obsolete punctured striæ near the suture, which vanish towards the extremity, and a scarcely punctured one next the margin, which is continued to the apex, the margin itself being sometimes narrowly edged with red; body beneath blue-black, apex of the abdomen rufous, legs short and wholly red. Length 3 lines.

This species was first described by Eschscholtz, in the 'Bulletin de la Société Impériale des Naturalistes de Moscou,' in 1830. It is very local and nowhere abundant. It is found upon some of the high moors in Derbyshire, Yorkshire, and in Scotland. I have taken it also on the mountains near Llangollen in North Wales, in August.

\section{Genus 37. ZABRUS, Clairville.}

Mentum dente medio integro. Ligula apice retusa; paraglossis membranaceis, extùs rotundatis, ligulam parum superantibus. 
Palpi articulo ultimo subcylindrico, penultimo breviore. Mandibulæ valida, breves. Labrum emarginatum. Tibiæ antica spiná apicali duplice. Tarsi antici maris articulis tribus dilatatis, singulis obcordatis, subtùs biseriatìm pectinatosetosis.

1. Z. piger : niger, convexus ; thorace transverso, posticè punctato, utrinque obsoletè impresso; elytris interdùm nigrosubaneis, parallelis, valdè convexis, punctato-striatis ; antennis tibiis tarsisque rufo-piceis.

Buprestis piger, Fourc. Ent. Paris. 1. 52 (1785).

Carabus gibbus, Fab. Ent. S. 4. 442 (1794).

Zabrus gibbus, Clairv. Ent. Helv. 2. 82.-Sturm, D. F. 4. 128. -Dej. Spec. 3. 453; Icon. 3. 234. pl. 159.-Steph. Mand. 1. 140, et Manual, p. 39.

Winged, convex, deep black, with sometimes a brassy tinge on the elytra. Head with an elevated transverse fold or band in front, behind which is a longitudinal impression in the middle of the forehead and a rugged fovea on each side; palpi and antennæ rusty red. Thorax transverse, narrowed in front, sides rather straight behind, posterior angles right angles, base as broad as the elytra, disk much wrinkled all over, the dorsal line crossed in front by a depressed space, on the sides of which appear a few punctures and longitudinal striæ, the base also depressed and much punctured, the punctures extending partly up the margins, the basal foveæ very slight. Elytra broad, parallel, very convex, coarsely punctate-striated; underside of the thorax in the middle, breast and sides of the abdomen punctured; femora black, tibiæ and tarsi red. Length $6 \frac{1}{2}$ lines.

This species, the only one of the genus found in Britain, is apparently local and uncommon. According to Stephens it occurred " in plenty at Worthing, in August 1817, and at Brighton the following year," - "in profusion at Hastings in September,"- " every autumn plentifully in the open corn-fields about Cambridge." It has been found also at Walmer and Richmond.

\section{Genus 38. AMARA, Bonelli.}

Mentum dente medio emarginato vel subemarginato, rariùs integro. Ligula apice truncata; paraglossis membranaceis, eam haud superantibus. Palpi maxillares articulo ultimo ovato, labiales articulo ultimo fusiformi vel subcylindrico. Mandibulæ breves, valida. Labrum levitèr emarginatum, vel subtruncatum. Tarsi antici maris articuïis tribus dilatatis. 
The genus Amara consists of two divisions; the first comprises those species which have the thorax quadrate or subquadrate, and dilated behind; and the second comprehends those which have the thorax narrowed behind. Amara, or the first division, has been furthermore subdivided by Zimmermann into the subgenera-

Amara, or species which have the posterior tibiæ of the $\delta$ densely pilose within.

Celia (from which Acrodon does not materially differ), or species which have the posterior tibiæ of the $\delta$ glabrous within or slightly pilose.

Percosia, or species which have the posterior tibiæ in both sexes glabrous.

The second division is likewise supposed to comprehend-

Leirus (Bradytus, Steph.), or species which have the posterior tibiæ densely pilose within.

Braditus (Curtonotus, Steph.), or species which have the posterior tibiæ in both sexes glabrous.

I am not, however, disposed to place much reliance on these subdivisions.

* Prothorax quadratus, subquadratus, posticè dilatatus.

1. A. obsoleta : ovata, plerumque anea; thorace posticè utrinque obsoletissimè bi-impresso; elytris striatis, striis posticè profundioribus; antennarum articulis tribus basi rufis; pedibus nigris.

Dej. Spec. 3. 460; Icon. 3.241.pl.160.-Steph.Mand.1.129, et Manual, p. 36.-Erichson, Käfer, 85.-Heer, Faun. Helv. 93. Carabus trivialis, Dufts. Faun. 2. 116.

Amara trivialis, Sturm, D. F. 6. 46. pl. 145.

Carabus ovatus, Fab. S. El. 1. 196.

Amara ovata, Sturm, D. F. 6. 51. pl. 146.-Steph. Mand. 1. 129 , et Manual, p. 36.

A. ingenua et subanea, Steph. Manual, p. 38.

Ovate, broad, above brassy, greenish brass, brassy black, blueblack, or, more rarely, brilliant shining green. Head smooth, transversely striated in front, palpi and antennæ brownish black, three joints at the base of the latter red. Thorax narrowed in front, anterior angles prominent, sides rounded and gradually widened to about the middle and presenting a somewhat dilated 
appearance, then straight, posterior angles very little produced, with the tip itself obtuse, disk convex, very smooth and sbining, the dorsal furrow very slender, the base with two obsolete foveæ on each side and a transverse indistinct impression at the base of the dorsal furrow. Elytra in front as broad as the thorax, ovate, sinuated a little at the apex, striated, the strix impunctate, but deeper at the extremity; legs black, tibiæ and tarsi with red cilia. Length $4 \frac{1}{2}$ lines.

Fabricius described an unusual variety of this insect (probably immature) under the name ovatus, having a brownish body and red legs. A. obsoleta, Dej., presents the typical characters of the species. A. ingenua, subanea and lata of the Stephensian collection belong to the present species.

Generally distributed, but not very abundant.

2. A. similata : oblongo-ovata, anea; thorace anticè angustato, basi utrinque subpunctato obsoletè bi-impresso; elytris striatis, striis subtilissimè punctulatis ; antennarum articulis tribus basi rufis, tibiis obscurè rufis.

Harpalus similatus, Gyll. Ins. Suec. 2. 138.

Amara similata, Dej. Spec. 4. 461 ; Icon. 3. 243. pl. 160.Steph. Mand. 1. 128, et Manual, p. 36.-Erichson, Käfer, 85. Carabus obsoletus, Dufts. Faun. 2. 116.

Amara obsoleta, Sturm, D. F. 6. 52. pl. 145.

Smaller and proportionally narrower than obsoleta, brassy brown. Head small, with a slight fovea on each side between the eyes, the antennæ brownish, with three joints at the base red. Thorax more narrowed in front than in obsoleta and less broad at the sides, the basal impressions more distinct and faintly punctured. Elytra striated, the striæ very faintly punctulated; tibiæ obscurely red. Length 4 lines.

Commonly distributed, and in profusion at Dover and on the South Downs.

3. A. acuminata : lata, ovata, anea; thorace posticè utrinque profundè uni-impresso; elytris apice subacuminatis, striatis, interstitiis subelevatis; antennarum articulis tribus basi rufis, pedibus nigris.

Carabus acuminatus, Payk. Faun. 1. 166.

Harpalus acuminatus, Gyll. Ins. Suec. 2. 136.

Amara acuminata, Sturm, D. F. 6. 42. pl. 143.-Erichison, Käfer, 86.-Heer, Faun. IIelv. 93.

Carabus eurynotus, Ill. Käfer, 1. 167. 
Amara eurynota, Dej. Spec. 3. 458 ; Icon. 3. 239. pl. 160.Steph. Mand. 1. 127, et Manual, p. 36.

A. arata, Steph. Mand. 1. 127.

Ovate, very broad, shining brassy. Head smooth, mouth, palpi and antennæ black, three joints at the base of the latter red. Thorax narrowest in front, anterior angles produced, very wide behind, having a slight abbreviated dorsal furrow and on each side at the base a very deep small pit remote from the posterior margin, hinder angles produced and acuminated. Elytra scarcely wider than the thorax, ovate, apex obliquely sinuated and acuminated, striated, the striæ impunctate, interstices rather elevated; legs black, tibix and tarsi with red cilia. Length 5 lines.

Generally distributed.

4. A. trivialis : oblongo-ovata, plerumque anea; thorace anticè angustato, basi utrinque foveolâ unicâ profundè impresso; elytris subtilitèr striatis; antennarum articulis tribus basi rufis; tibiis rufo-piceis.

Harpalus trivialis, Gyll. Ins. Suec. 2. 140.

Amara trivialis, Dej. Spec. 3. 464 ; Icon. 3. 246. pl. 160.Steph. Mand. 1. 129, et Manual, p. 36.-Erichson, Käfer, 87. -Heer, Faun. Helv. 94.

A. atra, Steph. Mand. 1. 134, et Manual, p. 37.

Variable in colour, being brassy, greenish brass, bright green, coppery, black or occasionally cyaneous. Head with an obsolete fovea on each side in front; three joints at the base of the antennæ red, the rest black. Thorax narrowed in front, as wide behind as the elytra, the angles produced, disk with a slight dorsal furrow and a deep small pit on each side at the base, somewhat after the manner of that in the preceding species, also close to the angles a small shallow impression. Elytra oblongovate, narrowed at the apex, finely striated; tibiæ pitchy red. Lergth $3 \frac{1}{2}$ lines.

$A$, atra, Steph., is a black individual of this species, which is extremely abundant everywhere.

5. A. spreta : ovata, fusco-cenea ; thorace anticè angustato, posticè utrinque bifoveolato obsoletèque punctato; elytris striatis, striis subtilissimè punctulatis; antennarum articulis tribus basi rufis; tibiis rufo-piceis.

Dej. Spec. 5. 791; Icon. 3. 248. pl. 161.-Erichson, Käfer, 87. - Heer, Faun. Helv. 94.

A. curta, Steph. Manual, p. 36 . 
Allied to vulgaris, brownish brassy with a coppery and greenish hue, sometimes brassy black, often entirely brassy. Head obscurely foveated in front, two joints at the base of the antennæ red, the rest wholly black and all the joints rather slender. Thorax shorter and narrower in front than in the next species, the dorsal furrow deeply impressed, the base with two very deeply impressed foveæ on each side and much punctulated, the anterior angles produced and the posterior ones rather acuminated. Elytra evenly striated throughout, the striæ very faintly punctulated, legs black, tibiæ pitchy reddish. Length $3 \frac{1}{2}$ lines.

$A$. curta, Steph., is a dark representative of this species, which is not very common. I have taken it in Kent and in some of the midland counties, and have received it from the north of England. "Hertford," Mr. Stephens. "On the Bents at South Shields, in May and June," Mr. Hardy. "Fifeshire," Mr. Murray.

6. A. vulgaris : oblongo-ovata, plerumque anea; thorace posticè utrinque obsoletè bistriato; elytris striatis, striis posticè profundioribus; antennis basi rufis ; tibiis rufo-piceis.

Carabus vulgaris, Linn. F. S. 799.-Müller, Prod. Zool. Dan. 79. Harpalus vulgaris, Gyll. Ins. Suec. 2. 138.

Amara vulgaris, Sturm, D. F. 6. 48.-Dej. Spec. 3. 463; Icon. 3. 243. pl. 160.-Steph. Mand. 1. 128, et Manual, p. 36.Heer, Faun. Helv. 94.

A. convexior, Steph. Mand. 1. 131.

A. obtusa, Steph. Mand. 1. 132.

A. laticollis, Steph. Mand. 1. 133, et Manual, p. 37.

Oblong-ovate, brassy black, or brassy brown, or dark metallic green, sometimes blue-black, rarely bright green. Head with a small impression on each side close to the eyes, first and second, sometimes also the third joint at the base of the antennæ red. Thorax narrowest in front, sides gradually widening till near the base when they turn a little inwards to meet the elytra, disk rather convex in front, the dorsal furrow slender and interrupted before, but reaching behind to the posterior margin, the base depressed, having on each side a double subpunctate impression, sometimes very indistinct and the usual little puncture close to the angle. Elytra oblong-ovate, convex, finely striated, the striæ deepening towards the extremity; legs brassy black, tibiæ and sometimes the tarsi pitchy red. Length $3 \frac{1}{2}$ lines.

The name contrusa, given to it by Schiodte, has been adopted on the Continent for this species, on the grounds that vulgaris, Linn., belongs, according to the Linnæan Collection, to the 
insect we know as Pterostichus melanarius, but, as before stated, the Linnæan diagnosis will not accord with that insect; I have therefore retained the name vulgaris for this.

A. obtusa, Steph., is a black variety of this insect: A. laticollis is an imperfectly formed of the same, to which also $A$. convexior must be assigned. A. plebeia of the Stephensian collection is represented by some examples of this species, but as the descriptions given by Stephens manifestly apply to the true plebeia, I have given his references to that insect.

This species, with all its varieties of colour, is generally distributed throughout the kingdom.

7. A. communis : oblonga, anea, nitida; thorace amplo, posticè utrinque subtilitèr punctulato foveolato; elytris subtilitèr striatis, striis subtilissimè punctatis ; antennis basi tibiisque rufis.

Harpalus communis, Gyll. Ins. Suec. 2. 145.

Amara communis, Sturm, D. F. 6. 49.-Dej. Spec. 3. 467 ; Icon. 3. 250. pl.161. - Steph. Mand. 1. 133, et Manual, p. 37. -Erichson, Käfer, 90.-Heer, Faun. Helv. 94.

Smaller, more oblong and more convex than vulgaris, brilliant brassy. Head as in the preceding species, palpi and antennæ black, two joints at the base of the latter red. Thorax broad, the anterior margins straight in the middle, but the angles produced, the sides less narrowed, the disk more convex, having numerous fine wrinkles on each side the dorsal furrow, and the entire base very minutely and closely punctured, and furnished on each side with a double obsolete fovea. Elytra oblong, sides almost straight, convex, finely striated, the striæ obsoletely punctured, the punctuation being sometimes almost imperceptible; legs black, tibiæ rusty red. Length 3 lines.

A. anea, Meg., is a brassy green variety of this insect, and $A$. ferrea, Sturm, a darker example of the same.

Commonly distributed.

8. A. curta : ovata, obscurè anea; thorace posticè utrinque obsoletè bistriato ; elytris striatis, striis apice profundioribus ; antennarum articulis duobus basi rufis; tibiis rufo-piceis.

Dej. Spec. 3. 468 ; Icon. 3. 253. pl. 161.--Erichson, Käfer, 88. - Heer, Faun. Helv. 95.

Shorter and wider in proportion to its sinaller size than communis, less convex, generally obscure brassy black or bronze with 
a greenish tinge, sometimes more brilliant brass. Head blackish, convex behind, obsoletely impressed in front of the antennæ, the latter with two joints at the base red, the rest brownish black with the tip testaceous. Thorax narrowed in front, sides rounded below the anterior angles, which are slightly prominent, then straight behind the middle and as broad as the elytra, the dorsal furrow transversely wrinkled in the middle and terminating at the base in some very fine longitudinal strix, between which and the angles are two obsolete impressions on each side, the inner one oblong and reaching to the hinder margin, the exterior one round. Elytra broad and rather shortish ovate, being a little widest behind the middle, simply striated, the striæ somewhat deeper at the apex, interstices flat; legs black, tibiæ rusty red. Length $2 \frac{3}{4}$ lines.

Not uncommon on the sand-hills at Deal in company with $A$. lucida and tibialis, but immediately distinguishable from either by its broader form.

9. A. familiaris : oblongo-ovata, anea; thorace anticè angustato, posticè obsoletè bi-impresso ; elytris subtilitèr striatis; antennarum articulis tribus basi pedibusque rufis.

Carabus familiaris, Dufts. Faun. 2. 119.

Harpalus familiaris, Gyll. Ins. Suec. 4. 145.

Amara familiaris, Dej. Spec. 3. 469 ; Icon. 3. 254. pl. 161.Steph. Mand. 1. 133, et Manual, p. 37.-Erichson, Käfer, 90. - Heer, Faun. Helv. 96.

A. cursor, Sturm, D. F. 6. 57.-Steph. Mand. 1. 130, et Manual, p. 37.

A. lavis, Steph. Mand. 1. 130.

A. lucida, Steph. Mand. 1. 134, et Manual, p. 37.

Oblong-ovate, brassy or greenish brass, bronzed black, sometimes pitchy with the margins of the thorax reddish. Head with a small impression on each side a little behind the antennæ, three joints at the base of the latter red. Thorax narrowed in front, with the anterior angles prominent, straight from about the middle to the posterior angles, which are rectangular, the dorsal furrow very slender, the base with two very shallow impressions on each side and without any appearance of punctuation. Elytra ovate, with the sides moderately rounded, very finely striated, the striæ a little deeper at the apex; legs entirely red. Length 3 lines.

A. lavis and lucida, Steph., are identical with the present species, which is extremely common.

10. A. Iucida : oblongo-ovata, viridi-anea ; thorace posticè utrin- 
que levitèr bifoveolato ; elytris punctato-striatis, striis apice profundioribus; antennarum articulis tribus basi pedibusque rufis.

Carabus lucidus, Dufts. Faun. 2. 121.

Amara erythropa, Steph. Mand. 1. 134, et Manual, p. 37.

A. infima, Steph. Mand. 1. 135, et Manual, p. 38.

A. gemina, Zimm. Gist. Faun. 1. 37.-Erichson, Käfer, 91 .

Similar in form to familiaris, but much smaller. Oblongovate, brassy green or green, blue-black or piceous; three joints at the base of the antennæ testaceous red. Thorax narrowed in front, the anterior angles not so prominent as in familiaris, but rather obtuse, sides rounded in front below the angles, then straight and as wide behind as the elytra, base with two lightly impressed fover on each side, the inner one largest and rather rugged. Elytra ovate, punctate-striated, the striæ rather deeper before the apex; legs entirely red. Length $2 \frac{1}{5}$ lines.

This species is found abundantly on sandy commons among moss, under stones and at the roots of plants in company with tibialis. Very plentiful at Deal, Rye, Isles of Wight and Portland; Hampstead Heath, \&c. \&c.

11. A. tibialis : oblongo-ovata, convexa, anea; thorace posticè utrinque profundè bifoveolato; elytris punctato-striatis; antennis basi tibiisque rufo-testaceis.

Carabus tibialis, Payk. Faun. 1. 168.

Harpalus tibialis, Gyll. Ins. Suec. 2. 145.

A. tibialis, Dej. Spec. 3. 471 ; Icon. 3. 256. pl. 162.-Steph. Mand. 1. 135, et Manual, p. 38.-Erichson, Käfer, 91.Heer, Faun. Helv. 96.

Carabus viridis, Dufts. Faun. 2. 120.

A. viridis, Sturm, D. F. 6. 60. pl. 147.

Smaller, narrower and more convex than lucida, shining brassy, or brassy black, sometimes purplish; antennæwith two (sometimes three) joints at the base testaceous red. Thorax narrower and more convex than in the preceding species, anterior angles slightly prominent, the basal fover more distinct and very deeply impressed, the interior one largest, somewhat triangular and touching the posterior margin, the exterior one being a deep round pit close within the angle. Elytra deeply punctatestriated throughout; legs black, with the tibir alone testaceous red. Length 2 lines.

Its narrower and more convex form, more brassy appearance, the deeper fover at the base of the thorax and the testaceous tibiæ sufficiently distinguish it from lucida.

Abundant on sandy commons. 
12. A. strenua : oblonga, convexa, anea; thorace basi utrinque profundè unistriato; elytris punctato-striatis, striis posticè profundioribus; antennarum articulis tribus basi rufotestaceis ; tibiis tarsisque ferrugineis ; tibiis anticis spinâ apicali tricuspi.

Zimm. Gist. Faun. 1. 32.-Erichson, Käfer, 84.

A. Vectensis, Dawson, Ann. Nat. Hist. 3. 213 (1849).

A. tricuspidata, Steph. Manual, p. 38.

Oblong, convex, above brassy brown, greenish brass, more rarely blue-black, head, thorax and elytra not always concolorous ; antennæ fuscous black, with the first, second, third and basal half of the fourth joints red. Thorax subquadrate, the breadth greater than the length, narrowed in front, anterior angles scarcely prominent, sides rounded till about the middle, after that nearly straight to the hinder angles, which are acutely prominent, the basal margin being sloped downwards at the extremities so as to give that appearance, disk convex, dorsal furrow transversely wrinkled and terminated before and behind in a slight depression, having numerous fine stria impressed thereon, the base being furthermore furnished with a very deep oblong stria or small fovea on each side about midway between the dorsal furrow and the lateral margins and a smaller one close to each angle. Elytra oblong, sides very slightly rounded, convex, finely punctatestriated, the punctures vanishing before the extremity when the striæ deepen; thighs pitchy black, tibiæ and tarsi rusty red; anterior tibiæ with the spine at the apex tricuspid, the middle mucro being longest, stoutest and slightly incurved, the inner one smallest. Length 4 lines.

This species has hitherto in this country been found exclusively in the Isle of Wight, and is usually abundant in the marshes near Ryde early in the spring.

13. A. plebeia : oblongo-ovata, anea, nitida; thorace posticè utrinque bifoveolato, foveis crebrè punctulatis; elytris punctato-striatis; antennarum articulis tribus basi tibiisque rufo-testaceis; tibiis anticis spinâ apicali tricuspi.

Harpalus plebeius, Gyll. Ins. Suec. 2. 141.

Amara plebeia, Dej. Spec. 3. 467; Icon. 3. 249.pl. 161.-Steph. Mand. 1. 132, et Manual, p.38.-Erichson, Käfer, 84.-Heer, Faun. Helv. 92.

A. nitida, Steph. Manual, p. 37.

Above brassy black, or greenish brass. Head convex, smooth and shining, obsoletely impressed in front, palpi and antennæ black, three joints at the base of the latter red. Thorax narrowed 
in front, anterior angles acutely prominent, sides regularly curved to behind the middle, then straight before the posterior angles, which are produced, disk convex in front, depressed behind, having two deep punctured foveæ on each side. Elytra oblongovate, narrowed and obliquely sinuated at the apex, striated, the striæ finely but distinctly punctured; femora black, tibia alone testaceous, tarsi pitchy; the spine at the apex of the anterior tibice tricuspid. Length 3 lines.

A. nitida, Steph. (not Sturm), is identical with this species; with which also that author's descriptions of plebeia correspond, though the individuals in his collection standing with that name belong to $A$. vulgaris.

This species is generally distributed.

\section{(Celia, Zimmermann.)}

14. A. ingenua : ovata, fusco-anea; thorace transverso, anticè subangustato, posticè utrinque bifoveolato, foveis punctatis ; elytris punctato-striatis; antennis pedibusque rufis.

Carabus ingenuus, Dufts. Faun. 2. 110.

Harpalus ingenuus, Gyll. Ins. Suec. 4. 443.

Amara ingenua, Dej. Spec. 3. 498 ; Icon. 3. 286. pl. 166.Erichson, Käfer, 92.-Heer, Faun. Helv. 88.

A. lata, Sturm, D. F. 6. 23.

A. subanea, Sturm, D. F. 6. 29.

Ovate, broad, obscure brassy, or dull blackish brass. Head very short, with two impressions behind the antennæ, which with the palpi are red. Thorax transverse, very short, narrowed in front, broad behind yet slightly sluped to the posterior angles which are rectangular, the base has two deep foveæ which are slightly punctured, the exterior fovea runs into the angle with an elevated ridge by the side of it externally. Elytra broader than the thorax, rounded and widening a little at the sides, narrowed at the apex, punctate-striated, the outer margin with a series of impressions at the base and before the apex; legs red. Length 4 lines.

This species appears to be very rare in this country; the only indigenous example I have seen was sent me from Scotland; it perfectly agrees with specimens received from Paris. The supposed examples in the Stephensian collection are to be referred to $A$. obsoleta.

15. A. oricalcica : oblongo-ovata, fusco-cenea ; thorace subquadrato, basi punctato utrinque bifoveolato, angulis posticis 
rectis; elytris punctato-striatis; antennis pedibusque ferrugineis.

Carabus oricalcicus, Müller, Prod. Zool. Dan. 79 (1776).

Harpalus bifrons, Gyll. Ins. Suec. 2. 144.

Amara bifrons, Dej. Spec. 3. 485; Icon. 3. 269. pl. 164.-Steph.

Mand. 1. 130, et Manual, p.38.-Erichson, Käfer, 94.-Heer,

Faun. Helv. 90.

A. brunnea, Sturm, D. F. 6. 56.

Carabus lividus, Fab. S. El. 1. 201.

Amara discrepans, Steph. Mand. 1. 131.

About the size of $A$. familiaris. Oblong-ovate, brassy brown, shining; mouth, palpi and antennæ rusty red, tip of the mandibles black. Thorax short, sides a little rounded below the anterior angles, broad behind, posterior margin almost straight, and the basal angles right angles, these together with the lateral margins rusty red, the base much depressed and punctured, with two large foveæ on each side which are strongly punctured. Elytra very little rounded on the sides, moderately convex, punctate-striated throughout, apex testaceous; legs wholly red. Length 3 lines.

This species, commonly known under the name $A$. bifrons, had been previously described as Carabus oricalcicus in the 'Zoologix Danicæ Prodromus,' 1776, which name I have restored to it in right of priority. The original example of C.lividus, Fab., in the Copenhagen Museum, is according to Erichson an immature individual of this species, to which also C. discrepans, Marsham, belongs. It is not a very common species, but has been taken near Richmond; at Hertford; South Shields and Berwick-uponTweed; and is likewise included among the Irish species.

\section{(Acrodon, Zimmermann.)}

16. A. brunnea : ovata, obscurè nigro-enea; thorace amplo, basi utrinque bifoveolato punctatoque, angulis posticis subrotundatis; elytris fortitèr punctato-striatis; antennis pedibusque rufis.

Harpalus brunneus, Gyll. Ins. Suec. 2. 143.

Amara brunnea, Dej. Spec. 3. 483 ; Icon. 3. 266. pl. 163.Steph. Mand. 1. 131, et Manual, p. 38. - Erichson, Käfer, 95.

Pitchy, thorax and elytra with a greenish metallic tinge, margins of the former narrowly red. Head smooth and convex behind, with a small oblong impression on each side in front, palpi and antennæ red. Thorax short and broad, a little narrowed in front and the anterior angles produced, sides dilated and rounded below them, then nearly straight or very slightly 
sloped inwards towards the base, which is depressed and punctured and has two punctured foveæ on each side, the exterior one smallest. Elytra ovate, moderately convex, strongly punctatestriated; underside black, legs red. Length $2 \frac{1}{2}$ lines.

Stephens's description corresponds with this species, but the examples in his cabinet belong to the preceding species.

Rare. Stated by Mr. Haliday to have been taken at Portmarnoch in Ireland, by Messrs. Tardy and Furlong.

\section{(Percosia, Zimmermann.)}

17. A. patricia : ovata, nigro-picea, nitida ; thorace transverso, posticè punctato, utrinque bifoveolato, angulis posticis rectis; elytris punctato-striatis; antennis pedibusque rufis.

Carabus patricius, Dufts. Faun. 2. 110.

Amara patricia, Dej. Spec. 3. 502; Icon. 3. 292. pl. 167.Erichson, Käfer, 92.-Heer, Faun. Helv. 87.

A. zabroides, Dej. Spec. 3. 504 ; Icon. 3. 294. pl. 167.

Bradytus marginatus, Curtis, Ann. Nat. Hist. 5. 274,-Steph. Manual, p. 39.

Pitchy black, very shining, margins of the thorax sometimes more or less red, broader, less convex and more ovate than the next species; palpi and antennæe wholly red. Thorax as wide again as the head, very short, the width about half as much more as the length, a little narrowed at the anterior angles, which are not prominent, rounded below them as far as the middle, then straight and with the posterior angles produced, the base very depressed punctured and with two large and very broad somewhat united punctured foveæ quite extending from the dorsal line to the hinder angles on each side. Elytra very broad ovate, deeply striated, the striæ finely punctured, interstices very smooth and glossy; legs red. Length 4-5 lines.

Not common. Mr. Curtis's examples of Bradytus marginatus, which correspond with this species, were taken at Boxhill. I have captured it at Deal; Folkstone; and near Beddgelert in North Wales in August.

** Prothorax posticè plus minus angustatus.

(Bradytus, Stephens.)

(Leirus, Zimmermann.)

18. A. consularis : oblongo-ovata, nigro-picea, nitida ; thorace subquadrato, posticè utrinque profundè bifoveolato, foveis 
punctatis; elytris crenato-striatis; antennis pedibusque ferrugineis.

Carabus consularis, Dufts. Faun. 2. 112.

Amara consularis, Sturm, D. F. 6. 26.-Dej. Spec. 3.501 ; Icon.

3. 290. pl.167.-Erichson, Käfer, 82.-Heer, Faun. Helv. 97.

Bradytus consularis, Steph. Mand. 1. 136.

B. crassus, Steph. Mand. 1. 131, et Manual, p. 39.

Harpalus latus, Gyll. Ins. Suec. 2. 133.

Oblong-ovate, pitchy black, very shining, the elytra of the $\delta$ sometimes metallic. Head smooth, a little rugose in front, palpi and antennæ ferruginous. Thorax short, slightly narrowed in front and very little rounded on the sides, scarcely narrowed behind, the posterior angles right angles, disk smooth and glossy, with an impressed dorsal furrow and two deep punctured foveæ on each side at the base, the inner one largest, and exterior to the outer one with an elevated fold running into the angle. Elytra rather broader than the base of the thorax, sides slightly rounded, crenate-striated, the strix deepening at the extremity, the outer margin with a series of deeper impressions interrupted in the middle; body beneath pitchy red, breast punctured, legs entirely ferruginous. Length $3 \frac{1}{2}-4$ lines.

This species resembles the preceding, but is narrower and more convex, and the basal fover are less expanded. B. crassus, Steph., is specifically identical with it. It is not a very common species, but has been taken occasionally within the London district and at Winterbourne Stoke. It is very abundant in Holme Fen, Huntingdonshire, under pieces of turf in May, and at Moor Park near Farnham under refuse left in turnip fields. It is likewise found in the north of England, in Scotland and Ireland.

19. A. apricaria : oblongo-ovata, fusco-subanea; thorace posticè subangustato bifoveolato, foveis punctatis; elytris punctatostriatis; antennis pedibusque rufis.

Carabus apricarius, Fab. Ent. S. 1. 163.-Fab. S. El. 1. 205. Harpalus apricarius, Gyll. Ins. Suec. 2. 104.

Amara apricaria, Sturm, D. F. 6. 19.-Dej. Spec. 3. 506 ; Icon. 3. 298. pl. 168.-Erichson, Käfer, 81 .

Bradytus apricarius, Steph. Mand. 1. 137, et Manual, p. 39. B. torridus, Steph. Mand. 5. 379.

Oblong-ovate, fuscous black, with a greenish brassy tinge on the elytra, palpi and antennæ ferruginous. Thorax convex, more narrowed behind as well as in front than in the preceding, so that the sides appear rather rounded and widest about the middle, the posterior angles likewise are a little more acute. Elytra 
broader than the base of the thorax, convex, punctate-striated, the punctures disposed across the striæ and disappearing behind the middle, leaving the striæ smooth to the extremity, the outer margin with a series of larger impressions; beneath pitchy, breast and sides of the abdomen punctured, legs red. Length $3 \frac{1}{2}$ lines.

Bradytus torridus, Steph., is an immature $q$ of this common species.

20. A. fulva: ovata, ferruginea; thorace brevi, subquadrato, posticè utrinque bifoveolato, foveis punctatis ; elytris æneomicantibus, punctato-striatis.

Carabus fulvus, De Geer, Ins. 4, 62.-Dufts. Faun. 2. 107.

Harpalus fulvus, Gyll. Ins. Suec. 2. 105.

Amara fulva, Dej. Spec. 3. 511 ; Icon. 3. 303. pl. 169.

Bradytus fulvus, Steph. Mand. 1. 137.

B. ferrugineus, Steph. Mand. 1. 137, et Manual, p. 39.

Ovate, ferruginous, paler beneath. Head short, with an impression on each side between the antennæ, which are pale testaceous. Thorax short and broad, with the sides rounded below the anterior angles, narrowed behind, hinder angles right angles, disk wrinkled, having a slight dorsal furrow, base with two punctured foveæ on each side, and exterior to them an elevated ridge running obliquely into the angle. Elytra rather broader than the base of the thorax, disk glossed with greenish or bluish brass, punctate-striated, the punctures vanishing before the apex; legs pale testaceous. Length $4 \frac{1}{2}$ lines.

Abundant at Low Moor near Bradford under the shale and stones; also found on sandy coasts at Ryde, Deal, Swansea, Lowestoff; and at Ripley, Surry.

\section{(Curtonotus, Stephens.) \\ (Braditus, Zimmermann.)}

21. A. spinipes : oblongo-ovata, nigro-picea; thorace lateribus rotundato, posticè coarctato, utrinque bistriato, basi apiceque punctulato ; elytris striato-punctatis ; antennis pedibusque rufis.

Carabus spinipes, Linn. F. S. 793.-Schrank, Enum. Ins. Aust. 212.

C. bicolor, Fab. Mant. 1. 199.-Payk. Mon. 122.

C. aulicus, Panz. Faun. 38 .

Harpalus aulicus, Gyll. Ins. Suec. 2. 101. 
Amara aulica, Dej. Spec. 3. 515; Icon. 3. 308. pl. 170. A. picea, Sturm, D. F. 6. 10.-Erichson, Käfer, 80.

Curtonotus piceus, Steph. Manual, p. 39.

Pitchy black. Head convex, with two foveæ between the eyes and a transverse line in front; mouth pitchy, palpi and antennæ red. Thorax with the sides rounded and widest about the middle, much contracted behind, the posterior angles acute, disk convex, anterior and posterior margins punctulated, the base with two very deep striæ on each side terminating below in a broad punctured fovea and exterior to these an elevated ridge running into the angle. Elytra ovate, widest behind the middle, deeply striated, the striæ finely punctured, the margin with about eight deep impressions placed between the middle and the extremity; underside pitchy, legs red. Length 5-6 lines.

The name given to this insect by Linnæus and Schrank is restored in right of priority. It is generally distributed, but apparently not very abundant.

22. A. convexiuscula : elongata, fusco-picea, subcenea; thorace lateribus rotundato, posticè coarctato punctato utrinque bifoveolato; elytris punctato-striatis ; antennis pedibusque rufis.

Carabus convexiusculus, Marsham, Ent. 462.

Curtonotus convexiusculus, Steph. Mand. 1. 138. pl. 8, et Manual, p. 39.

Amara convexiuscula, Dej. Spec. 3.517; Icon. 3. 310. pl. 170.

Narrower and more elongate than the preceding species; pitchy fuscous with a slight brassy tinge. Head smaller, the impressions between the eyes slighter, the mouth, mandibles (except the tip which is black), palpi and antennæ red. Thorax short, narrower, the anterior angles more rounded, sides less dilated, hinder angles acute, disk convex, the anterior margin either not at all punctulated or with merely a few scattered punctures, and the basal fover less deep and rugged. Elytra narrower and more elongate, striated, the striæ more distinctly punctured; body beneath pitchy, legs and apex of the abdomen wholly red. Length $5 \frac{1}{2}$ lines.

An abundant species on the banks of the Thames, below Gravesend; near Southend, Whitstable and Herne Bay; Ryde; shores of the Tees, \&c., \&c.; and in the salt marshes near Cork. 


\section{Genus 39. ANISODACTYLUS, Dejean.}

Mentum dente medio nullo. Ligula apice truncata; paraglossis coriaceis, acuminatis. Palpi articulo ultimo fusiformi. Labrum quadratum, apice vix emarginatum. Tibiæ anticæ spiná apicali unica. Tarsi anteriores maris articulo secundo, tertio et quarto valdè dilatatis, primo angustiore, omnibus his subtùs densè spongiosis.

1. A. binotatus : niger, thorace subquadrato, posticè punctulato utrinque foveolato; elytris striatis; antennarum articulo primo tarsisque rufis.

Carabus binotatus, Fab. Mant. 1. 199.-Fab. S. El. 1. 193.

Harpalus binotatus, Gyll. Ins. Suec. 2. 122.-Steph. Mand. 1. 157.

Anisodactylus binotatus, Dej. Spec. 4. 140; Icon. 4. 72. pl. 177. -Steph. Manual, p. 46.-Erichson, Käfer, 42.

Harpalus rufitarsis, Steph. Mand. 5. 381.

H. calceatus, Steph. Manual, p. 45.

Oblong, deep black. Head with two red (sometimes confluent and occasionally obsolete) spots on the crown, basal joint of the antennæ red. Thorax subquadrate, the breadth greater than the length, sides rounded, obliquely narrowed behind, posterior angles acute, disk obsoletely wrinkled, with an impressed central line, and two shallow punctured foveæ at the base, which is likewise punctured. Elytra oblong, sides somewhat parallel, apex slightly sinuated, disk strongly striated, the outer margin with numerous punctures; legs black with the tarsi reddish, the legs sometimes entirely red, Length $4 \frac{1}{2}-5 \frac{1}{2}$ lines.

H. rufitarsis and calceatus of the Stephensian cabinet are identical with this species, which is generally distributed in marshy places.

2. A. pœciloides : viridi-cneus vel nigro-cupreus; thorace subquadrato, posticè utrinque foveolato punctatoque, angulis posticis subrotundatis; elytris striatis; antennarum articulo primo rufo.

Harpalus pociloides, Steph. Mand. 1. 154.

Anisodactylus pociloides, Steph. Manual, p. 45.

A. virens, Dej. Spec. 4. 135 ; Icon. 4. 67. pl. 176.

Above brassy green or dusky copper, sometimes brilliant shining green. Head with two fover in front and sometimes a 
red spot on the crown, basal joint of the antennæe red, with a dusky streak above. Thorax subquadrate, rather short, sides rounded and widest in the middle, posterior angles rather rotundate, disk transversely wrinkled, the dorsal line deeply impressed in the middle, base with a large punctured fovea on each side more or less strongly impressed, the punctures extending a little way up the lateral margins. Elytra oblong, a little sinuated before the apex, striated, the margin with a few scattered punctures, and the third interstice occasionally with from one to five impressions near the extremity; underside greenish black, minutely punctured; legs black. Length $5 \frac{1}{2}$ lines.

Rather local: shores of the Thames below Gravesend, near the Fort; Isle of Sheppey; Southend; Deal; Lymington Salterns in May and June.

\section{Genus 40. DIACHROIMUS, Erichson.}

Mentum dente medio brevi obtusiusculo. Ligula porrecta cornea, apice medio sinuata; paraglossis membranaceis, obtusis, ligulam paululùm superantibus. Palpi articulo ultimo fusiformi. Labrum quadratum, apice emarginatum. Tibiæ anticæ spinâ apicali duplici. Tarsi anteriores maris articulis dilatatis, subtùs aqualiter spongiosis, ultimo transversim cordato.

1. D. germanus : ovatus, subpubescens, confertissimè punctatus; capite elytris antennis pedibusque rufo-testaceis; thorace elytrorumque maculâ posticâ cyaneis.

Carabus germanus, Linn. S. N. 2. 671.-Fab. S. El. 1. 204. Harpalus germanus, Sturm, D. F. 4. 99.-Dej. Spec. 4. 230; Icon. 4. 130. pl. 184.

Ophonus germanus, Curtis, Ent. pl. 191.-Steph. Mand. 1. 164. Diachromus germanus, Erichson, Käfer, 44.-Steph. Manual, p. 48.

Head testaceous red, densely and finely punctured, and with an obsolete fovea on each side; palpi and antennæ red, eyes and tip of mandibles black. Thorax bluish or greenish, short, sides dilated and rounded below the anterior angles, contracted behind, posterior angles right angles, the entire surface densely punctured, base with two impressions, central line obsolete. Elytra ovate, testaceous red, with a bluish or greenish black patch at the apex, striated, interstices thickly and minutely punctured, 
very pubescent; underside of thorax and abdomen black, legs pale testaceous. Length $4-4 \frac{1}{2}$ lines.

"Near Kingsbridge in Devonshire." Dr. Leach.

\section{Genus 41. HARPAIUS, Latreille.}

Mentum dente medio brevi obtuso, vel obsoleto. Ligula apice truncata vel sinuata; paraglossis membranaceis, rotundatis, ligulam haud superantibus. Palpi filiformes, articulo ultimo fusiformi. Mandibulæ breves, obtusiuscula. Labrum quadratum, vix emarginatum. Tarsi anteriores maris articulis quatuor valdè dilatatis, subtùs biseriatìm pectinato-setosis, primo triangulari, cateris obcordatis.

The genus Ophonus was established by Ziegler and Megerle in order to receive certain species of Harpali, which were supposed to present characters at variance with those that properly belong to that genus. Dejean, and after him, most entomologists, have now suppressed it and restored the species it comprised to the genus Harpalus, because it was found upon examination that they did not present points of distinction sufficiently important and decided to warrant their separation. In common with the other Harpali, they have a simple tooth (obtuse or obsolete) in the middle of the mentum; the upper lip, the mandibles, the palpi and antennæ do not differ; and although in some species the anterior and intermediate tarsi of the males are densely spinose and the upper surface of the body in both sexes is pubescent, yet these are characters which they possess in common with some of the indisputable Harpali; all that remains therefore is the punctuation of the upper surface, which, of itself, cannot be considered of sufficient importance to characterize a genus.

* Prothorax punctatus ; elytra striata, interstitia creberrimè punctata.

\section{(Ophonus, Ziegler.)}

1. H. sabulicola : oblongus, subpubescens, capite thoraceque nigro-piceis, punctatis, hoc quadrato posticè angustato, angulis posticis obtusis ; elytris cyaneo-violaceis, striatis, interstitiis punctatissimis; antennis pedibusque rufis.

Carabus sabulicola, Panz. Faun. 30.

Harpalus sabulicola, Sturm, D. F. 4. 87.-Dej. Spec. 4. 195; Icon. 4. 93. pl. 179.-Heer, Faun. Helv. 101.

Ophonus sabulicola, Steph. Mand. 1. 160, et Manual, p. 46. 
Oblong, subpubescent, head and thorax pitchy black, strongly punctured, palpi and antennæ red. Thorax quadrate, sides rounded, narrowed behind, posterior angles obtuse but not rounded, disk very convex, more coarsely punctured than in obscurus, the punctures larger and most numerous at the base, the latter not depressed. Elytra violaceous, oblong, striated, interstices strongly punctured, apex entire; legs red. Length $5 \frac{1}{2}-6 \frac{1}{2}$ lines.

Local: Southend; Dorking; Winterbourne Stoke; Halesworth, Suffolk; abundant under stones and clods of earth about the arable fields near Basingstoke and many chalky districts of the south.

2. H. obscurus: oblongus, subpubescens, capite thoraceque nigropiceis, subtilitèr punctatis, hoc subquadrato, angulis posticis subrotundatis ; elytris cyaneis, striatis, interstitiis punctatissimis; antennis pedibusque rufis.

Carabus obscurus, Fab. S. El. 1. 192.

Harpalus obscurus, Sturm, D. F. 4. 85. pl. 92.-Dej. Spec. 4. 197 ; Icon. 4. 96. p. 179.-Heer, Faun. Helv. 102.

Ophonus obscurus, Steph. Mand. 1. 160, et Manual, p. 46. O. stictus, Steph. Mand. 1. 159. pl. 8.

This species bears a considerable resemblance to sabulicola, but is sufficiently distinct. Head smaller, more finely punctured, palpi and antennæ red. Thorax subquadrate, the breadth much greater than the length, so as to appear sensibly shorter than in sabulicola, sides rounded, but scarcely narrower behind than in front, posterior angles evidently more rounded and a little elevated, disk less convex, more finely sculptured, base depressed and with two obsolete foveæ. Elytra cyaneous, striated, interstices very closely and minutely punctured, apex obliquely sinuated; legs red. Length 5-6 lines.

Commonly distributed in chalky districts.

3. H. azureus: oblongo-ovatus, subpubescens, viridis vcl cyaneus ; capite subtilitèr thorace profundè punctatis, hoc subquadrato, angulis posticis obtusiusculis ; elytris striatis, interstitiis punctatissimis; antennis pedibusque rufis.

Carabus azureus, Fab. Mant. 1. 201.-Fab. S. El. 1. 196. IHarpalus azureus, Dej. Spec. 4. 207 ; Icon. 4. 107. pl.181.Erichson, Käfer, 45.-Heer, Faun. Helv. 102.

Ophonus azureus, Steph. Mand. 1. 161, et Manual, p. 47.

C. chlorophanus, Panz. Faun. 73. 
H. chlorophanus, Sturm, D. F. 4. 108.-Dej. Spec. 4. 205; Icon. 4. 106. pl. 181.

Var. $\beta$. Pauld major; capite thoraceque nigro-piceis, elytris subvirescentibus.

Oblong-ovate, slightly pubescent, above bright green or cyaneous. Head depressed in front, convex behind, moderately and finely punctured; mouth, palpi and antennæ red. Thorax subquadrate, the breadth rather greater than the length, sides moderately rounded, posterior angles somewhat obtuse, disk convex, deeply and coarsely punctured, the punctures most numerous at the base and at the hinder angles. Elytra a little wider than the thorax, sides very moderately rounded, obliquely sinuated before the apex, striated, the interstices closely and minutely punctured; legs red. Length $3 \frac{1}{4}$ lines.

This species is extremely abundant on the south coast of the Isle of Wight, near the Culver Cliffs, \&c. "Taken occasionally beneath stones, in June and July, near Darenth Wood and at Hertford; also at Bottisham, Kimpton, Leith Hill and Newmarket." Mr. Stephens.

The variety $\beta$. (which I was at first disposed to consider a distinct species) differs from it chiefly in having the head and thorax pitchy black, without any tinge of green, and the elytra very obscurely green; it is also a rather larger insect, but its form and sculpture are similar. I have two examples (both $q$ ) taken by myself in the Isle of Wight: Mr. Wollaston has one from Devonshire and the Rev. H. Clark another from the neighbourhood of Northampton, the characters of all which agree most perfectly.

4. F. punctatulus : oblongo-ovatus, subpubescens, obscurè viridis, capite subtilitèr thorace fortiùs punctatis, hoc subquadrato posticè subangustato, angulis posticis rectis; elytris striatis, interstitiis punctatissimis; antennis pedibusque rufo-testaceis.

Carabus punctatulus, Dufts. Faun. 2. 89.

Harpalus punctatulus, Sturm, D. F. 4. 101.pl. 93.-Dej. Spec.

4. 202 ; Icon. 4. 102. pl. 180.-Erichson, Käfer, 45.

Ophonus punctatulus, Steph. Mand. 1. 160.

O. nitidulus, Steph. Mand. 1. 161, et Manual, p. 46.

Oblong-ovate, rather depressed, subpubescent, above green, sometimes cyaneous. Head convex, shining, finely and remotely punctured in front, nape smooth and glossy; mouth pitchy red, palpi and antennx entirely red. Thorax subquadrate, broad, 
sides rounded in front below the angles, narrowed behind the middle, but straight before the hinder angles, so as to form with the base a right angle, disk convex in the middle, but depressed before and behind, strongly punctured, the punctures most numerous at the base, which has a broad, obsolete fovea on each side. Elytra very little wider than the base of the thorax, sides very gradually rounded from below the humeral angles to just before the apex, which latter is obliquely sinuated, striated, interstices thickly and finely punctured; legs red. Length 4 lines.

Ophonus nitidulus, Steph., is identical with this species, which is local, and occurs chiefly in the early spring, under stones and clods of earth, at Newark, Bottisham, Hertford, Richmond, Kimpton, Swansea, near Sandown in the Isle of Wight, and in other parts of England.

5. H. cordatus : elongatus, subpubescens, ferrugineus; capite thoraceque fortitèr punctatis, hoc cordato pasticè coarctato, angulis posticis rectis; elytris subparallelis, striatis, interstitiis punctatissimis, maculâ oblongâ posticâ fuscâ; antennis pedibusque rufo-testaceis.

Carabus cordatus, Dufts. Faun. 2. 169.

Harpalus cordatus, Sturm, D. F. 4. 106. pl. 94.-Dej. Spec. 4. 214 ; Icon. 4. 115. pl. 182.-Heer, Faun. Helv. 103.

Elongate, subpubescent, ferruginous red. Head finely punctured, with a shallow fovea on each side in front, eyes black, palpi and antennæ testaceous. Thorax heart-shaped, sides very much rounded from the anterior angles to about the middle, thence much narrowed till just before the hinder angles, when they become straight so as to form with the base a right angle, disk convex, regularly punctured, with a slight dorsal line and an obsolete fovea on each side at the base. Elytra oblong, wider than the thorax, shoulders very little rounded, sides almost parallel, striated, interstices thickly and finely punctured, the posterior portion covered by an oblong obscure dark patch extending up the sides and leaving the centre more or less ferruginous; underside of the body and the legs testaceous. Length 4 lines.

A single example only of this species has fallen under my notice, which I captured near Deal, at the roots of the tall wiry grass which grows on the sand-hills.

6. H. rupicola: elongatus, subpubescens, capite thoraceque punctatis, rufescentibus, hoc subcordato, angulis posticis subrectis; elytris piceis, obscurè nigro-subvirescentibus, 
striatis, interstitiis punctatissimis; antennis pedibusque rufo-testaceis.

Sturm, D. F. 4. 105. pl. 94.

H. subcordatus, Dej. Spec. 4. 215 ; Icon. 4. 116. pl. 183.Heer, Faun. Helv. 103.

Elongate, slightly pubescent. Head rufescent, distinctly punctured, palpi and autennæ testaceous. Thorax longer than in puncticollis, anterior angles less prominent, sides rounded in front but more obliquely narrowed behind, which gives it the appearance of a more cordate form (Pl. II. f. 4), and renders the posterior angles less rectangular, disk more convex and the base less depressed, strongly but not densely punctured. Elytra narrower and more elongate, pitchy with occasionally an obscure greenish tinge, striated, the interstices very closely punctured; legs testaceous. Length $3 \frac{1}{2}$ lines.

The more convex and more cordate form of the thorax, which has its sides obliquely narrowed behind and its posterior angles more obtusely formed, as well as the narrower and more elongate shape of the entire insect, readily serve to distinguish this species from more slender and paler examples of puncticollis. One individual standing under the name foraminulosus, and two or three under that of punctatissimus in the Stephensian collection, may be referred to this species.

Not common : chalky districts, Dorking, Basingstoke, Isle of Wight, \&c.

7. H. puncticollis : oblongo-ovatus, subpubescens, piceus ; capite thoraceque punctatis, hoc subquadrato, angulis posticis rectis ; elytris striatis, interstitiis punctatissimis; antennis pedibusque rufo-testaceis.

Carabus puncticollis, Payk. Faun. 1. 120.

Harpalus puncticollis, Gyll. Ins. Suec. 2. 108.-Dej. Spec. 4. 216 ; Icon. 4. 117. pl. 183.

Carabus foraminulosus, Marsham, Ent. 457.

Ophonus foraminulosus, Steph. Mand. I. 162.

O. punctatissimus, Steph. Mand. 1. 162.

O. puncticeps, Steph. Mand. 1. 163, et Manual, p. 47.

Oblong-ovate, pitchy, slightly pubescent. Head usually reddish, sparingly and finely punctured; palpi and antennæ testaceous. Thorax nearly quadrate (Pl. II. f. 3), but the width rather less than the length, sides a little rounded below the anterior angles and a little narrowed behind, but having the hinder angles rectangular, disk subconvex, moderately punctured, 
the base depressed and more coarsely punctured, having the usual obsolete impression on each side. Elytra oblong-ovate, striated, interstices closely and finely punctured; body beneath pitchy red with the sides darker; legs testaceous. Length $2 \frac{3}{4}-3 \frac{1}{4}$ lines.

This species is very variable in size and somewhat in the colour of the thorax. Some examples do not exceed two-thirds the stature of others. The thorax is rufescent as well as the head in frequent individuals, which likewise present a narrower form. The typical example of Carabus foraminulosus, Marsham, must be referred to this species. The Stephensian collection is in a very confused state with regard to some of these allied species, but the references given apply to the major part of the individuals standing under the respective names to which I have assigned them.

Widely distributed.

8. H. cribellum : oblongo-ovatus, subpubescens, piceus; capite thoraceque parciùs punctatis, hoc breviore, lateribus anticè dilatato, angulis posticis rectis; elytris striatis, interstitiis punctatissimis; antennis pedibusque rufo-testaceis.

Ophonus cribellum, Steph. Mand. 1. 163, et Manual, p. 47.

O. subpunctatus, Steph. Mand. 1. 163, et Manual, p. 47.

Harpalus brevicollis, Dej. Spec. 4. 218 ; Icon. 4. 119. pl. 183.Erichson, Käfer, 46.-Heer, Faun. Helv. 103.

Oblong-ovate, pitchy or pitchy black, pubescent, palpi and antennæ testaceous. Thorax very short, the sides much dilated and rounded below the anterior angles, hinder angles right angles, the disk more sparingly punctured than in the preceding species. Elytra broad and rather depressed, finely striated, interstices minutely punctured; legs red. Length $2 \frac{3}{4}-3 \frac{1}{2}$ lines.

The chief points of distinction between this insect and puncticollis consist in the remarkable shortness of its thorax and the greater breadth before the middle. $O$. cribellum, subpunctatus and puncticollis of the Stephensian cabinet must be assigned to the present species.

Not uncommon; especially in chalky districts.

9. H. pubescens : oblongus, pubescens, punctatus, piceus vel piceo-testaceus; thorace cordato, basi utrinque impresso; elytris striatis, subparallelis, maculâ communi posticâ abdomineque nigro-piceis; pedibus rufo-testaceis.

Carabus pubescens, Payk. Mon. 61.-Payk. Faun. 1. 124. 
Harpalus pubescens, Gyll. Ins. Suec. 2.109.-Dej. Spec. 4. 236; Icon. 4. 137. pl. 185.

Ophonus pubescens, Steph. Mand. 1. 164, et Manual, p. 47.

Oblong, very pubescent, sometimes entirely pitchy, with the margins of the elytra testaceous, sometimes ferruginous with a common black or pitchy black or brown patch on the elytra, and sometimes wholly ferruginous or paler. Head punctured, usually rusty red with a dusky stripe extending down the centre; palpi and antennæ ferruginous. Thorax cordate, sides rounded in front below the angles and narrowed behind, the entire surface strongly punctured, having the usual dorsal furrow and a deep impression close to each hinder angle. Elytra oblong, sides nearly straight, finely striated, striæ minutely punctured, interstices distinctly but not closely punctured; legs reddish testaceous. Length 3 lines.

Common in marshy places and on the banks of tidal rivers.

10. H. obsoletus : oblongo-ovatus, subpubescens, subtilitèr punctatus, testaceus; thorace brevi, subquadrato, basi utrinque impresso; elytris striatis, maculâ oblongâ nigro-piceâ.

Dej. Spec. 4. 252 ; Icon. 4. 132. pl. 184.

Ophonus obsoletus, Steph. Manual, p. 47.

This insect is nearly allied to the preceding, but sufficiently distinguished by several important characters. It is always a broader and more robust insect, and never attains to the dark colour of pubescens. It is uniformly testaceous with an oblong pitchy or dusky streak on each elytron, the head being also occasionally dark. Though immature examples of pubescens resemble it in colour, its form and sculpture are dissimilar. The thorax is shorter, broader, less convex and distinctly margined; the elytra are wider, their humeral angles prominent and the sides evidently rounded, and the entire surface is minutely and closely punctured, the punctuation on the interstices of the wing-cases especially instead of being sparingly distributed as in pubescens is very densely placed. Length $3 \frac{1}{2}$ lines.

Abundant under clods of earth in the Salterns near Lymington.

** Elytra striata, interstitia lavigata rariùs subtilissimè punctulata.

(HaRPalus $p r$.)

11. H. ruficornis: oblongus nigro-piceus; thorace subquadrato posticè punctato-rugoso utrinque foveolato ; elytris striatis, 
interstitiis subtilissimè punctulatis, fulvo-pubescentibus ; antennis pedibusque rufis.

Carabus ruficornis, Fab. Mant. 1. 199.-Fab. S. El. 1. 182.

Harpalus ruficornis, Gyll. Ins. Suec. 2. 107.-Steph. Mand. 1.

158, et Manual, p. 45.-Dej. Spec. 4. 249; Icon. 4. 142.

pl. 186.-Erichson, Käfer, 47.-Heer, Faun. Helv. 105.

Oblong, head and thorax black; mouth, palpi and antennæ red. Thorax subquadrate, slightly narrowed behind, posterior angles right angles, disk transversely strigose, dorsal furrow met in front by a longitudinally strigose impression, base punctured and with two rough shallow fovex. Elytra opake, clothed with a short griseous pubescence with more or less of a golden gloss, finely striated, the interstices minutely punctulated, the exterior margin with a series of small impressions; underside black, legs red. Length 6-7 lines.

Very common.

12. H. æneus : oblongus, plerumque viridi-aneus; thorace subquadrato, basi utrinque foveolato punctato ; elytris striatis, lateribus obsoletè punctulatis, apice profundè sinuatis subdentatis; antennis pedibusque rufis.

Carabus eneus, Fab. S. El. 1. 197.-Dufts. Faun. 2. 74.

Harpalus aneus, Gyll. Ins. Suec. 2. 116.-Steph. Mand. 1. 155, et Manual, p. 45.-Dej. Spec. 4. 269; Icon. 4. 148. pl. 187. -Erichson, Käfer, 47.-Heer, Faun. Helv. 105.

Var. $\beta$. Pedibus nigro-piceis.

H. confusus, Dej. Spec. 4. 271 ; Icon. 4. 150. pl. 187.

Var. $\gamma$. Elytris apice levitèr sinuatis.

This insect is extremely variable in colour, being brassy, greenish brass, greenish copper, bright green, purple, blue-black, or black, thorax and elytra not always concolorous. Head convex, shining, with a fovea on each side in front, antennæ red. Thorax subquadrate, the width rather greater than the length, very slightly narrowed behind, the disk convex, dorsal line met in front by a transverse depression, base punctured very finely in the middle, having a punctured shallow fovea on each side. Elytra oblong, sides almost straight, apex obliquely sinuated and more or less deeply notched, finely striated, the marginal interstice and sometimes the two next obsoletely punctured; legs red, sometimes pitchy black. Length 5 lines.

The variety with pitchy black legs is very common. Individuals with purple elytra have their legs always dark.

Very common. 
13. H. honestus : oblongus, plerumque viridi-cyaneus; thorace brevi subquadrato basi utrinque profundè unistriato; elytris striatis, interstitio septimo apice punctato; antennis rufis articulo 2, 3 et 4 basi fuscis; tibiis tarsisque piceis.

Carabus honestus + , Dufts. Faun. 2. 85. 93.

Harpalus honestus, Dej. Spec. 4. 299; Icon. 4. 162.pl. 189.Heer, Faun. Helv. 106.

Carabus ignavus ठో, Dufts. Faun. 2. 85. 94.

Harpalus rufipalpis, Sturm, D. F. 4.70.pl.89.-Steph. Manual, p. 44.

H. annulicornis et atrocceruleus, Steph. Mand. 1. 150.

$H$. notatus et obscuricornis, Steph. Mand. 1. 151.

H. nitidus, Steph. Mand. 1. 153, et Manual, p. 44.

H. maculicornis, Steph. Mand. 5. 381, et Manual, p. 43.

Variable in colour, blue, blue-black, bronzed, sometimes bright green, with all intermediate shades; in this country the colour is more subdued, the elytra being usually blue-black or cyaneous in the $\delta$ and entirely dull black in the $q$, with the head and thorax shining black in both sexes. Head depressed in front, with a small deep pit on each side connected by a transverse line; palpi and antennæ red, the second, third and fourth joints of the latter more or less dusky at their base. Thorax short and broad, sides rather rounded and widest about the middle, posterior angles not quite rectangular, the dorsal line interrupted before and behind, base with two deep striæ touching the hinder margin. Elytra broader than the thorax and rather short, a little rounded at the sides and sinuated at the apex, striated, the seventh interstice with a few punctures at the extremity and the marginal one with a series of impressions; legs pitchy black, tarsi red. Length 4 lines.

H. rufipalpis, annulicornis, atrocaruleus, notatus, obscuricornis, nitidus and maculicornis, Steph., belong to this species, which is plentiful in sandy districts, especially in the south; abundant on Woking Common, \&c., and near Bristol.

14. H. sulphuripes : oblongus, nigro-subcyaneus; thorace subquadrato, posticè magis angustato utrinque unistriato, angulis posticis subrectis; elytris striatis; antennis tibiis tarsisque rufis.

Germ. Spec. Nov. 1. 24.-Dej. Spec. 4. 302 ; Icon. 4. 165. pl. 189.-Heer, Faun. Helv. 106.-Redt. Faun. Aust. 100.

Oblong, narrower than honestus, black, elytra of the $\delta$ with a cyaneous tinge. Head with two small punctures between the eyes; palpi and antennæ entirely red and immaculate. Thorax 
longer than in honestus, sides more rounded below the anterior angles, more contracted behind, dorsal furrow intersected by a few transverse wrinkles, base with two oblong deep impressions. Elytra oblong, finely striated, the seventh interstice impunctate at the apex; femora pitchy black, tibiæ and tarsi ferruginous red. Length $3 \frac{3}{4}$ lines.

This species is now for the first time introduced into the British Fauna on the authority of an example taken near Bristol, which perfectly corresponds with specimens received from Paris. One of the insects standing under the name servus in the Stephensian cabinet appears to correspond with this species.

15. II. cuniculinus: capite thoraceque nigrts, elytris subcyaneis; thorace lateribus anticè rotundato, posticè subangustato, utrinque unistriato, angulis posticis rectis ; elytris striatis, interstitio septimo apice punctato ; antennis rufo-testaceis, articulo 2, 3 et 4 nigro-maculatis ; pedibus nigro-piceis, tarsis rufis.

Carabus cuniculinus, Dufts. Faun. 2.87 (1812).

Harpalus cuniculinus, Sturm, D. F. 4. 61. pl. 87 (1818).Steph. Mand. 1. 15\%, et Manual, p. 44.

This insect is narrower than honestus, to which it bears considerable resemblance; the head and thorax are shining black, the elytra have a distinct purplish or cyaneous tinge, the palpi and antennæ are testaceous red, the second, third and fourth joints of the latter ringed with black at their base. Thorax quadrate, not so short as in honestus, the sides dilated and rounded in front below the anterior angles, then contracted towards the hinder angles, which are right angles, the disk smooth, the dorsal furrow very fine, the base impunctate, with a single short stria on each side touching the posterior margin. Elytra oblongovate, sides nearly even or very slightly rounded, sinuated at the apex, flattish on the disk, simply striated, the seventh interstice with a few punctures at the extremity and the margins with a series of deeper impressions; underside of the body and legs pitchy black, tarsi red. Length 4 lines.

This species was first established by Duftschmidt, on the authority of a single $\delta$ in his possession, and has since been received as an acknowledged species. It bears a close affinity to honestus, of which it is perhaps no more than a narrower and more slender variety. Stephens's description of cuniculinus appears to correspond with this insect, but the examples standing under this name in his cabinet belong more properly to 
honestus. I have seen a pair, however, in the collection of Mr. Curtis, which perfectly correspond with the description and figure given by Sturm of this insect.

16. H. Iuteicornis : oblongo-ovatus, niger; thorace quadrato, posticè utrinque levitèr unistriato obsoletèque punctulato, angulis posticis rectis; elytris striatis, ante apicem levitèr emarginatis; ore antennis tarsisque rufo-testaceis.

Carabus luteicornis, Dufts. Faun. 2. 86.

Harpalus luteicornis, Sturm, D. F. 4. 60. pl. 87.-Gyll. Ins. Suec. 4. 435.-Dej. Spec. 4. 329 ; Icon. 4. 189. pl. 192.Erichson, Käfer, 51.-Heer, Faun. Helv. 108.

H. servus, Steph. Mand. 1. 152, et Manual, p. 44.

Black or pitchy black, sometimes with the margins of the thorax narrowly edged with red. Head smooth, mouth, palpi and antennæ entirely reddish testaceous. Thorax quadrate, rather convex, rounded at the angles before the middle, the posterior angles right angles, the base with an oblong impression on each side touching the posterior margin, in which are a few obsolete punctures, and the disk with the usual dorsal furrow. Elytra about the width of the thorax, sides rather straight or very little rounded, narrowed behind and with the margin very slender just before the apex, disk convex, simply striated; femora blackish, tibiæ and tarsi red, the latter sometimes palest. Length 3 lines.

Of the two individuals contained in the Stephensian collection, standing incorrectly under the name servus, one appears to correspond with this species and the other with sulphuripes, but neither of them have anything in common with the true servus, Sturm. There are two other examples in Mr. Curtis's cabinet and two or three in the National Collection, which will likewise, I believe, be found to accord with it, besides the examples which may exist in private collections. The insect is found very sparingly in sandy districts in the south.

17. H. attenuatus : oblongo-ovatus, nigro-piceus; thorace subquadrato, posticè subangustato, utrinque profundè foveolato, foveis punctatis, angulis posticis rectis; elytris striatis ; antennis tibiis tarsisque rufis.

Steph. Mand. 1. 152, et Manual, p. 44.

H. consentaneus, Dej. Spec. 4. 302 ; Icon. 4. 166. pl. 189.

H. picilabris, Steph. Mand. 5. 381, et Manual, p. 43.

Smaller and narrower than honestus, oblong, pitchy black, or pitchy without any tinge of blue. Head glossy, with two deeper punctures connected by a transverse line between the eyes; palpi 
and antennæ entirely red. Thorax subquadrate, more narrowed behind, posterior angles more entirely rectangular, disk very convex, with a central longitudinal line touching the base and met in front by a transverse curved impression, on each side at the base a broad punctured fovea midway between the dorsal line and the hinder angles. Elytra broader than the thorax, sides less rounded, apex broader and less sinuated, deeply striated, interstices more convex, the seventh wholly impunctate; femora pitchy black, tibiæ and tarsi red. Length $3 \frac{1}{2}-4$ lines.

This species is found abundantly on Woking Common; near Folkstone and Sandgate; also at Swansea; in Devonshire, Hants, Isle of Wight, and North Wales on sandy commons; as well as in the London districts.

18. I. atricormis : oblongo-ovatus, ater; thorace subquadrato, anticè posticèque subangustato, posticè leviter punctulato, utringue fovenlato; elytris striatis, apice subsinuatis ; antennis pedibusque piceo-nigris.

Steph. Mand. 5. 379, et Manual, p. 40.

H. nigricornis, Steph. Mand. 5. 381, et Manual, p. 44.

Deep shining black. Head with a fovea on each side between the eyes ; antennæ pitchy black, with the basal joint red. Thorax short, the width being greater than the length, rather narrowed before and behind, the sides rounded, posterior angles right angles, the dorsal stria fine and the base with a shallow fovea on each side, which together with the entire base is finely punctured. Elytra oblong-ovate, slightly widest behind the middle, apex obliquely sinuated, convex, inoderately striated, margins with a few slight impressions at the base and towards the extremity. Length 4 lines.

This insect, which I have been unable to identify with any foreign species, is represented in the Stephensian collection by four examples under the name atricornis, and by one under that of nigricornis; the localities given are "near London, Windsor, and in Glamorganshire."

19. H. Wollastoni : oblongus, niger; thorace subquadrato, posticè punctato, utrinque foveolato, angulis posticis subrectis ; elytris fortitèr striatis; antennis palpis tarsisque rufo-ferrugineis, femoribus tibiisque nigro-piceis.

Oblong, black. Head with a deep fovea on each side between the antennæ connected by a fine transverse line, palpi and antennæ ferruginous red. Thorax subquadrate, the breadth greater than the length, the anterior margin straight in the middle, but the 
angles slightly prominent, sides rather narrowed in front, then rounded as far as the middle, from whence they are obliquely sloped to the posterior angles which are nearly rectangular, but the apex of the angle itself is somewhat obtuse, disk convex, transversely wrinkled, the dorsal furrow abbreviated before and behind, and terminating at both extremities in a distinct impression, the base and basal angles punctured, and with a large shallow roughly punctured fovea on each side about midway between the dorsal furrow and the hinder angles. Elytra oblong, broader than the thorax, sides scarcely rounded, apex obliquely sinuated, convex, deeply striated, the margin with a series of coarse impressions below the shoulders and before the apex; legs pitchy with the tarsi always and the tibiæ occasionally ferruginous red. Length $5 \frac{1}{2}$ lines.

Four or five examples of this species were captured by Mr. Wollaston, in May 1852, at Slapton Ley, Devonshire; and as I have not been able to identify it with any recorded species, I have named it after the captor.

20. H. discoideus : oblongus, nigro-piceus; thorace elytrisque tenuitèr rufo-marginatis, illo quadrato, posticè punctato utrinque levitèr impresso, angulis posticis rectis; elytris maris viridi-æneis, striatis; antennis pedibusque mufis.

Carabus discoideus \&, Fab. Ent. S. 1. 157.-Fab. S. El. 1. 199. Harpalus discoideus, Erichson, Käfer, 49.

H. perplexus \&, Gyll. Ins. Suec. 4. 434.-Dej. Spec. 4. 314 ; Icon. 4. 173. pl. 190.-Steph. Mand. 5. 380, et Manual, p. 43. H. Caffer, Steph. Mand. 1. 157, et Manual, p. 45.

Oblong, pitchy black, shining, elytra of the $\delta$ brassy green or cyaneous, margins of the thorax and of the elytra, together with the suture, narrowly edged with red. Head with a small fovea on each side between the eyes and a transverse line in front; palpi and antennæ testaceous red. Thorax nearly quadrate, sides slightly rounded and widest in the middle, posterior angles right angles, disk shining, transversely wrinkled, dorsal line abbreviated in front, base with a broad rugose fovea on each side, the fover and the entire base being also thickly punctured. Elytra oblong, sides not quite parallel, striated, interstices smooth; legs and tip of the abdomen red. Length $4 \frac{1}{2}$ lines.

Erichson informs us that he has seen in the Fabrician collection a $q$ of this insect placed as $C$. discoideus; and that C. Petiffi, Dufts., and H.perplexus, Gyll., are the $q$, but H. Petiffi, Sturm, the $\delta$ of the same species. The Fabrician name must therefore be adopted. H. Caffer of the Stephensian cabinet also must be 
assigned to this species. The true C. Caffer, Dufts., is a larger insect and is not found in Britain.

Not common: I have found it only in the Isle of Wight and near Sandy, in Bedfordshire, very early in the spring; it is to be sought for in 'sandy districts.

21. H. fulvipes : oblongo-ovatus, nigro-piceus; thorace subquadrato, basi punctato utrinque subfoveolato, angulis posticis obtusiusculis ; elytris striatis; antennis pedibusque rufis.

Carabus fulvipes, Fab. S. El. 1. 180.- + , Dufts. Faun. 2. 84.91. Harpalus fulvipes, Sturm, D. F. 4. 58. pl. 86.-Erichson, Käfer, 50.

Carabus limbatus đ̊, Dufts. Faun. 2. 84. 92.

Harpalus limbatus $\delta^{\circ}$, Sturm, D. F. 4. 50. pl. 83.-Steph. Mand.

1. 149, et Manual, p. 43.-Dej. Spec. 4. 327; Icon. 4. 186. pl. 192.

H. acuminatus et lateralis, Steph. Mand. 5. 380, et Manual, p. 43.

Oblong-ovate, pitchy black, with the margins of the thorax narrowly testaceous. Head wide, depressed in front, with a transverse line more or less evident between the eyes, palpi and antennæ red. Thorax subquadrate, the width rather greater than the length, anterior margin nearly straight, sides rounded at the angles, then almost straight to the base, posterior angles rather obtuse, disk depressed, transversely wrinkled on each side the dorsal furrow, which in some examples is met in front by a few longitudinal striæ, the base, together with two wide foveæ fincly punctulated, sometimes a little rough. Elytra ovate, widest behind the middle, striated, most deeply in the $\delta$, interstices very smooth, the seventh impunctate at the apex; legs red. Length 4 lines.

Erichson informs us that he has seen this insect standing as C. fulvipes in the Fabrician collection, and C. rufibarbis, Fab., agreeing therewith; also that $C$. fulvipes, Dufts., is the $q$ and C. limbatus, Dufts., the $\delta$ of the same species, of which also H. flaviventris, Sturm, is an immature example. In the Linnæan cabinet a portion of the specimens placed to represent $C$. latus belong to this species, but they can scarcely have been intended by our great naturalist to represent the insect referred to by him under that name. $H$. acuminatus and lateralis of the Stephensian cabinet belong to this species. Examples sometimes occur with red heads, and these represent $C$. erythrocephalus, Fab., and $H$. ruficeps of British collections.

\section{Common.}


22. H. rubripes : oblongo-ovatus; thorace subquadrato, posticè utrinque punctulato, subfoveolato, angulis posticis subrectis ; elytris striatis, interstitio septimo apice punctis pluribus impresso; antennis pedibusque rubris.

Mas, suprà viridi-aneus vel cyaneus nitidus: fœmina, capite thoraceque nigro subcyaneis, elytris opacis.

Carabus rubripes, Dufts. Faun. 2. 77.

Harpalus rubripes, Sturm, D. F. 4. 55.-Dej. Spec. 4. 339 ; Icon. 4. 194. pl. 193.-Steph. Mand. 1. 147, et Manual, p. 42.-Erichson, Käfer, 49.-Heer, Faun. Helv. 107.

H. azurescens, Gyll. Ins. Suec. 4. 432.

H. azureus, Steph. Mand. 1. 147, et Manual, p. 42.

H. chloropterus, marginellus et fulvipes, Steph. Mand. 1. 148, et Manual, p. 42.

H. subsinuatus, Steph. Mand. 1. 149, et Manual, p. 43.

H. lentus, Steph. Mand. 1. 150, et Manual, p. 43.

H. ignavus, Steph. Mand. 1. 153, et Manual, p. 44.

II. Petiffi, Steph. Mand. 5. 380, et Manual, p. 42.

Var. $\beta$. pedibus nigro-piceis.

H. punctiger et nigro-caruleus, Steph. Mand. 1. 149, et Manual, p. 42.

Head and thorax greenish black, elytra brilliant green, purple or blue-black and shining in the $\delta$; head and thorax black, elytra obscure dull green in the $q$. Head smooth and convex behind, depressed in front, with a small deep pit on each side, connected by a transver'se line, palpi and antennæ red. Thorax subquadrate, the breadth greater than the length, slightly narrowed in front, posterior angles nearly rectangular, disk covered with numerous transverse wrinkles, the dorsal furrow strongly marked and terminating in a deeper impression behind, base with two foveæ, which, together with the base itself, are punctured, but more sparingly and less distinctly in the $q$. Elytra as broad as the base of the thorax, sides very slightly rounded, deeply striated, interstices convex in the $\delta$, less deeply striated and the interstices flatter in the $q$, the seventh sometimes with a few small punctures near the extremity, margin with a series of deeper impressions ; underside black, legs red, femora sometimes blackish with the tibiæ and tarsi pitchy, cilia red. Length $4 \frac{1}{2}-5$ lines.

H. rubripes, azureus, chloropterus, fulvipes, marginellus, lentus, subsinuatus, Petiffi, ignavus, nigro-creruleus, and punctiger (in part) must be assigned to this species. The two last are varieties with pitchy black legs, and lentus an immature $q$. The true lentus, Sturm, is identical with tardus. 
Abundant in sandy and gravelly localities in the south of England and midland counties, more sparingly distributed northward of London.

23. I. cupreus : oblongo-ovatus, latior, plerumque viridi-aneus; thorace subquadrato, posticè obsoletè punctato, utrinque subfoveolato ; elytris profundè striatis ; antennis basi rufis; pedibus nigro-piceis.

Dej. Spec. 4. 281; Icon. 4. 160.pl. 188.-Steph. Mand. 1. 146, et Manual, p. 42.

Larger and broader than rubripes, generally coppery, or brassy green, the elytra sometimes brilliant green. Head smooth and very convex, forehead with a deep impression on each side, connected by a transverse line in front; antennæ rusty red with the basal joint brighter red. Thorax subquadrate, broad, slightly narrowed in front, hinder angles rather obtuse, disk with a slight dorsal line and two wide shallow foveæ, which, together with the base itself and the hinder angles, are thickly and finely punctured. Elytra deeply striated, the usual short sutural striæ longer than in others of the genus, interstices convex, the margin with a few punctures near the apex, the suture generally brownish brass; underside of the body black, legs pitchy black with the claws and cilia reddish. Length 6 lines.

This insect appears to be very scarce: I have met with it only at Ryde, Cowes and Sandown in the Isle of Wight. Stephens gives as its locality, the shores of the Thames below Gravesend.

24. H. depressus : oblongo-ovatus, niger, thorace viridi-cyaneo, subquadrato, anticè subangustato, posticè punctulato utrinque obsoletè impresso, angulis posticis obtusiusculis; elytris profundè striatis, interstitio quinto septimoque punctis impressis ; antennis basi rufis.

Carabus depressus, Dufts. Faun. 2. 73.

Harpalus depressus, Sturm, D. F. 4. 15. pl. 80.-Steph. Mand. 1. 146, et Manual, p. 41.-Heer, Faun. Helv. 111.

Carabus melampus, Dufts. Faun. 2. 96.

Harpalus melampus, Sturm, D. F. 4. 19. pl. 80.-Steph. Mand. 5. 379, et Manual, p. 41.

H. thoracicus, Steph. Mand. I. 145, et Manual, p. 41.

H. semiviolaceus, Dej. Spec. 4. 346 ; Icon. 4. 203. pl. 194.

Oblong-ovate, shining black, with the base of the thorax (more rarely its entire surface) greenish blue or cyaneous in the $\delta$, dull black in the $q$. Head depressed in front, and with a transverse 
impression between the eyes; palpi and base of the antennæ bright red, the third and fourth joints of the latter dusky, the rest dull red. Thorax subquadrate, broad, anterior angles prominent, sides very slightly rounded, hinder angles rather obtuse, disk much wrinkled transversely on each side the shallow dorsal furrow, base with two obsolete greenish foveæ, which, together with the hinder angles, are punctured. Elytra scarcely so wide in front as the base of the thorax, the sides rather rounded, but again narrower at the apex which is obliquely sinuated, disk deeply striated, interstices convex in the $\delta$, the fifth and seventh with several impressions near the extremity, and the margin with a continuous series; legs black, claws red. Length 6-7 lines.

Rather local, but plentiful in chalky districts of the south; in profusion on the side of Box Hill, also at Dover, and in the Isles of Wight and Portland.

25. II. tardus : oblongo-ovatus, niger; thorace antrorsùm subangustato, posticè utrinque impresso ; elytris striatis, striis obsoletissimè punctatis; antennis tarsisque rufo-testaceis.

Carabus tardus, Panz. Faun. 37.-Fab. S. El. 1. 194.

Harpalus tardus, Gyll. Ins. Suec. 2. 120.-Dej. Spec. 4. 363 ; Icon. 4. 217. pl. 195.-Erichson, Käfer, 54.

Carabus rufimanus, Marsham, Ent. 441.

Harpalus rufimanus, Steph. Mand. 1. 143.

H. fuliginosus et latus, Steph. Mand. 1. 143, et Manual, p. 40.

Oblong-ovate, shining black, the elytra of the $q$ duller black. Head obsoletely impressed in front, palpi and antennæ testaceous red. Thorax broad, slightly narrowed in front and the anterior angles a little prominent, posterior angles rather obtuse, disk smooth on each side the dorsal furrow, base with a more or less distinct oblong impression on each side touching the posterior margin. Elytra slightly narrower in front than the thorax, a little sinuated at the apex, striated, the striæ less strongly impressed in the o and very obsoletely punctulated in both sexes; femora and tibiæ pitchy black, basal part of the latter and the tarsi red. Length $4 \frac{1}{2}$ lines.

Carabus rufimanus, Marsham, is the insect here described, but $H$. tardus of the Stephensian collection is identical with $H$. serripes, from which the present species is easily distinguished by its less convexity of form, its rufous tarsi, and the absence of the dusky rings on the third and fourth joints of the antennæ. $H$. fuliginosus and latus, Steph., also belong to this species, which is very common in sandy districts, but more sparingly distributed in the north. 
26. II. melancholicus : oblongus, subdepressus, niger; thorace subquadrato, antrorsùm subangustato, posticè utrinque impresso, angulis posticis subrectis; elytris subparallelis, striatis, interstitio octavo apice punctis impresso ; antennis ferrugineis nigro-maculatis; pedibus piceis. (Pl. II.f.1.)

Dej. Spec. 4. 359; Icon. 4.213.pl.195.-Erichson, Käfer, 55.Redt. Faun. Aust. 99.

Rather smaller and narrower than tardus, and as depressed as the $f$ of that species, with which it cannot be confounded on account of its remarkably parallel form. Head smooth, with an impression on each side in front; palpi and antennæ red, the second, third and fourth joints of the latter dusky. Thorax subquadrate, a little narrowed in front and rounded below the angles, but the hinder portion of the sides straight, and the posterior angles not quite rectangular but a little obtuse, disk very much corrugated, base considerably depressed, with a fovea on each side midway between the dorsal furrow and the exterior margin. Elytra rather parallel, the apex obliquely sinuated and contracted, the striæ much deeper than in tardus, with some impressions on the eighth interstice from the suture behind and numerous punctures all along the margin; legs pitchy, tarsi palest. Length $4 \frac{1}{4}$ lines.

Examples of this insect, which I have recorded for the first time among our indigenous Harpali, were captured by $\mathrm{Mr}$. Wollaston near Swansea in 1845.

27. H. serripes : oblongo-ovatus, convexus, niger ; thorace antrorsùm subangustato, posticè utrinque impresso, angulis posticis subrectis; elytris striatis; antennis ferrugineis nigro-maculatis; pedibus nigro-piceis.

Carabus serripes, Schönh. Syn. 1. 199.-Dufts. Faun. 2. 98. Harpalus serripes, Sturm, D. F. 4. 26. pl. 81.-Steph. Mand. 1. 142, et Manual, p. 40.-Dej. Spec. 4. 371; Icon. 4. 222. pl. 196.-Erichson, Käfer, 55.

H. stygius, Steph. Mand. 1. 142, et Manual, p. 40.

H. fuscipalpis, Steph. Mand. 1. 144, et Manual, p. 40.

H. tenebrosus, Steph. Mand. 1. 382, et Manual, p. 45.

Oblong-ovate, convex, deep black. Head depressed in front, with a fovea on each side at the base of the antennæ connected by a transverse line and also a small round pit in the centre of the crown; the basal joint of the antennæ bright red, the rest dull ferruginous with the second and some of the following joints dusky at their base. Thorax with the anterior margin curved inwards in the middle so that the angles appear prominent, a 
little narrowed, sides gradually rounded and widening to about the middle, when they insensibly curve inwards to the posterior angles which are somewhat obtuse, disk transversely wrinkled, dorsal furrow deep in the middle but abbreviated or obsolete before and behind, base rather rugose, having an oblong impressed fovea on each side. Elytra narrowed in front to meet the base of the thorax, then wider but with the sides very slightly rounded, apex obliquely sinuated, convex, striated, the third interstice with a puncture behind close to the second stria; legs pitchy black. Length 5 lines.

H. stygius, fuscipalpis and tenebrosus, Steph., agree with this species, which is common in sandy districts near the southern coasts.

28. H. anxius: oblongo-ovatus, niger; thorace anticè subangustato, posticè utrinque impresso, angulis posticis subrectis ; elytris striatis; antennis palpisque ferrugineis; pedibus nigro-piceis.

Carabus anxius, Dufts. Faun. 2. 101.

Harpalus anxius, Sturm, D. F. 4. 72. pl. 89.-Gyll. Ins. Suec. 4. 439.-Dej. Spec. 4. 375; Icon. 4. 227. pl. 197.-Steph. Mand. 1. 144, et Manual, p. 41.-Erichson, Käfer, 57.

$H$. nigripes et piger, Steph. Mand. 1. 144, et Manual, p. 41.

$H$. femoralis, coracinus et flaviventris, Steph. Mand. 1. 145, et Manual, p. 41.

H. luteicornis, Steph. Mand. 1. 153, et Manual, p. 44.

Shining black. Head depressed in front, transversely impressed on each side between the antennæ, which with the palpi are entirely red, occasionally pitchy red. Thoras subquadrate, broad, a little narrowed in front and rounded below the angles to about the middle, thence continued almost straight towards the posterior angles which are a little obtuse, the posterior margin being slightly curved or obliquely sloped towards them, the disk with a fine dorsal furrow transversely wrinkled on each side and met in front and behind by some distinct longitudinal striæ, on each side at the base about midway between the dorsal furrow and the hinder angles and tuuching the posterior margin is a deep oblong impression; the lateral margins sometimes ferruginous. Elytra oblong-ovate, with the sides very slightly rounded, moderately and simply striated, the striæ more slender in the $q$ and the interstices smoother and flatter; femora pitchy black, tibiæ and tarsi pitchy red, the latter palest. Length $3-3 \frac{3}{4}$ lines.

H. coracinus, flaviventris and luteicornis, Steph., are immature 
examples of this insect, the last being a small $q$. Individuals frequently occur which are more or less ferruginous red. $H . n i$ gripes, piger and femoralis of the Stephensian cabinet must likewise be referred to this species, which is found in great profusion on sandy coasts.

\section{(Actephilus, Stephens.)}

29. F. neglectus : ovatus, niger, nitidus; thorace brevi, lateribus rotundato, posticè utrinque profundè uni-impresso, angulis posticis obtusis; elytris striatis, antennis basi tarsisque ferrugineis, femoribus tibiisque nigro-piceis.

Dej. Spec. 4.306 ; Icon. 4. 171.pl. 190.-Erichson, Käfer, 58. -Redt. Faun. Aust. 101.

H. piger, Sturm, D. F. 4.31.-Gyll. Ins. Suec. 4.438.-Heer, Faun. Helv. 111.

Actephilus pumilus, Steph. Mand. 1. 155, et Manual, p. 46.

Ovate, shining black. Head smooth and convex, with a transverse line between the antennæ, basal joint of the latter (with the palpi) red, the second and some of the following joints dusky, the apex dull red. Thorax short, sides rounded and dilated about the middle, posterior angles obtuse, disk very smooth and glossy, dorsal furrow distinctly impressed, base with an oblong very deep impression on each side touching the basal margin, the exterior margin with a few fine punctures just above the hinder angles. Elytra ovate, moderately convex, deeply striated, the third interstice with a puncture behind close to the second stria; legs pitchy black, cilia and tarsi red. Length $3 \frac{1}{2}$ lines.

This species has the thorax considerably shorter, less narrowed in front, less wide behind and the sides more rounded and dilated about the middle than in anxius, and it may be furthermore distinguished from that species by the dusky rings on some of the joints of the antennæ:

The name piger having previously been appropriated to another species, Dejean's name is employed for this. It is found on sandy coasts; in profusion under stones on the Chesil bank.

30. H. vernalis : ovatus, nigro-piceus ; thorace transverso, lateribus et angulis posticis rotundato; elytris striatis; antennis palpisque ferrugineis, pedibus rufo-piceis.

Carabus vernalis, Fab. S. El. 1. 207.-Dufts. Faun. 2. 106. Actephilus vernalis, Steph. Mand. 1. 154, et Manual, p. 46. Carabus picipennis, Dufts. Faun. 2. 102. 
Harpalus picipennis, Sturm, D. F. 4. 75. pl. 90.-Gyll. Ins. Suec. 4. 439.-Dej. Spec. 4. 379 ; Icon. 4. 231. pl. 197.Erichson, Käfer, 58.-Heer, Faun. Helv. 115.

Ovate, pitchy black. Head with the usual small impression on each side in front, palpi and antennæ red. Thorax transverse, sides gradually and very slightly rounded from the anterior angles to the base, with the posterior angles likewise somewhat rounded, disk convex, transversely wrinkled, the dorsal furrow well impressed, base with an oblong stria on each side which sometimes assumes the form of a deep pit, wholly impunctate. Elytra ovate, finely striated; legs pitchy red. Length $2-3$ lines.

This species is the Carabus vernalis of Fabricius, but not Harpalus vernalis of Gyllenhal; the latter has been already recorded (Pterostichus). It is a coast species, but rather local; not uncommon under stones on the Chesil bank and in similar localities in the south, as well as on the coasts of Norfolk, Suffolk and Essex.

\section{Genus 42. MASOREUS, Dejean.}

Mentum dente medio nullo. Ligula apice truncata; paraglossis membranaceis, eam longè superantibus. Palpi articulo ultimo subovato, apice truncato. Tarsi articulo quarto integro: unguiculis simplicibus.

1. M. Wetterhallii : rufo-piceus nitidus ; thorace brevi, dilatato, lateribus rotundato; elytris ovatis, subtilitèr punctatostriatis, basi ferrugineis; palpis antennis pedibusque rufotestaceis.

Harpalus Wetterhallii, Gyll. Ins. Suec. 3. 698.

Masoreus Wetterhallii, Erichson, Käfer, 25.

M. luxatus, Dej. Spec. 3. 537 ; Icon. 3. 325. pl. 171.-Curtis, Ent. pl. 287.-Steph. Mand. 5. 383, et Manual, p. 48.

Trechus laticollis, Sturm, D. F. 6. 103.

Above pitchy red, very shining. Head pitchy black, very smooth and glossy, having a small pit on each side at the base of the antennæ, which together with the palpi are entirely testaceous red, eyes and tip of the mandibles black. Thorax transverse, very short and broad, with its sides rounded, posterior angles subrotundate, disk convex, dorsal furrow strongly impressed and extending to the base. Elytra somewhat ovate, with the apex obliquely truncate, moderately convex, finely striated, the striæ delicately punctured, interstices flat, the base ferruginous red, the rest pitchy black; legs entirely testaceous. Length $2 \frac{1}{2}$ lines. 
Gyllenhal's name is restored to this species in right of priority.

The insect is somewhat local, but maybe taken rather plentifully on the Chesil bank, in the Isle of Portland; on the sand-hills at Deal ; and near Sheerness, in May and June.

\section{Genus 43. STENOLOPHUS, Megerle.}

Mentum dente medio nullo. Ligula apice truncata; paraglossis membranaceis, subrotundatis, ligulam haud superantibus. Palpi articulo ultimo fusiformi, apice subacuminato. Mandibulæ breves, acutiuscula. Labrum transversum, quadratum, apice truncatum. Tarsi anteriores maris articulis dilatatis, subtìs biseriatìm pectinato-setosis, ultimo aut bifido, aut obcordato.

* Tarsi antici maris articulo penultimo profundè emarginato, bilobo.

1. S. Teutonus : oblongus; capite pectore abdomineque nigris ; thorace rufo, quadrato, posticè utrinque subfoveolato, angulis posticis subrotundatis ; elytris rufis, striatis, maculâ magnâ communi posticâ nigro-subcyaneâ ; antennarum basi pedibusque testaceis.

Carabus Teutonus, Schrank, Enum. Ins. Aust. 214. no. 404 (1781).

C. vaporariorum, Fab. Mant. 1. 205 (1787).-Fab. S. El. 1. 206.-Panz. Faun. 16 (1789-1810).-Dufts. Faun. 2. 141. Harpalus vaporariorum, Gyll. Ins. Suec. 2. 161.-Sturm, D. F. 4. 120.

Stenolophus vaporariorum, Dej. Spec. 4. 407 ; Icon. 4. 239. pl. 198.-Steph. Mand. 1. 165. pl. 9, et Manual, p. 48.Erichson, Käfer, 59.-Heer, Faun. Helv. 115.

Oblong. Head black, with a small deep fovea on each side in front; mouth, palpi and two joints at the base of the antennæe testaceous, the rest of the antennæ fuscous black. Thorax red, quadrate, sides very slightly rounded, the posterior angles obtuse or subrotundate, the dorsal line very indistinct, transversely wrinkled and met in front by a slight depressed space, the base with a smooth shallow impression on each side. Elytra oblong, sides almost straight, obliquely sloped at the tip, striated, interstices flat, red in front, and with a large blue-black or cyaneous patch covering the hinder part, common to both and extending more or less upwards, sometimes leaving the shoulders alone 
red; underside of the thorax red, breast and abdomen black; legs testaceous. Length 3 lines.

Schrank's name is restored to this species in right of priority. It is local ; but occasionally plentiful in Hammersmith marshes, Battersea fields, \&c.; Fakenham; and in the Cambridgeshire fens.

2. S. Skrimshiranus: oblongus, capite pectore abdomineque nigris; thorace rufo, subquadrato, posticè utrinque sub. foveolato, angulis posticis rotundatis; elytris rufis, striatis, disco posteriore brunneo; antennarum basi pedibusque pallidè testaceis.

Steph. Mand. 1. 166, et Manual, p. 48.

Like Teutonus, but inferior in size, and having the elytra entirely rufous, with the exception of a dusky, more or less indistinct iridescent cloud at their extremity which blends with the rufous colour. Head shorter, with similar impressions, mouth, palpi and two joints at the base of the antennæ testaceous, the rest of the latter fuscous. Thorax shorter, subquadrate, the breadth being greater than the length, the posterior angles more rounded, disk convex, the basal impressions smaller and a little deeper. Elytra oblong, more narrowed at the shoulders than in the preceding species, the sides more rounded, disk more deeply striated and the interstices more convex; underside as in the above species, legs paler testaceous. Length $2 \frac{3}{4}$ lines.

Abundant near Niton, Isle of Wight, in the spring and autumn; also taken at Madingley Wood and in the Cambridgeshire fens, and near Yaxley, but very local.

3. S. vespertinus : oblongus, ater; thorace quadrato, posticè utrinque foveolato, foveis punctatis, angulis posticis subrotundatis ; elytris brunneo-testaceis, striatis, disco posteriore atro subcyaneo; thoracis margine antennarum basi pedibusque testaceis.

Carabus vespertinus, Ill. Käfer. 1. 197 (1798).-Panz. Faun. 37 (1789-1810).-Dufts. Faun. 2. 147 (1812).

Stenolophus vespertinus, Dej. Spec. 4. 421 ; Icon. 4. 241.pl. 198. -Steph. Mand. 1. 166, et Manual, p. 48.-Erichson, Käfer, 60.-Heer, Faun. Helv. 116.

Var. $\beta$. elytris atris cyaneo micantibus, margine pallido.

Carabus Ziegleri, Panz. Faun. 108. 
This insect resembles Teutonus in form, but is smaller. Head black and shining, with a fovea on each side in front, palpi testaceous, penultimate joint ringed with fuscous black, antennæ fuscous black with the basal joint testaceous. Thorax quadrate, a little rounded at the sides, posterior angles subrotundate, entire margin narrowly, and the posterior angles, edged with testaceous, base with a wide punctate fovea on each side. Elytra oblong, rather narrow, deeply striated, the interstices convex, dusky testaceous, with a black, somewhat cyaneous patch behind, extending upwards considerably and sometimes covering the entire disk and leaving the shoulders and margins alone pale; underside black, legs pale testaceous. Length $2 \frac{1}{2}$ lines.

Pale examples of this species cannot be confounded with Skrimshiranus, because the form is different. The thorax is more quadrate and the posterior angles are less rounded, in which respects it resembles Teutonus; whereas in Skrimshiranus the thorax is shorter, more narrowed behind, and the posterior angles are distinctly rounded; the basal foveæ, moreover, in vespertinus are broader and evidently punctured.

This species is somewhat local, but in many places abundant. It is found in marshes and on the banks of rivers, \&c. Hammersmith; Battersea fields ; Brentford and Kingsbury; Southend; Whittlesea Mere and the Cambridgeshire fens; near Norwich, \&c.

4. S. elegans: oblongus, capite pectore abdomineque nigris, thorace ferrugineo, lato, subquadrato, posticè coarctato utrinque foveolato, angulis posticis rotundatis; elytris rufotestaceis, striatis, maculâ oblongâ posticâ nigro-subcyaneâ; antennarum basi, tibiis tarsisque testaceis, femoribus obscurioribus. (Pl. II. f. B.)

Dej. Spec. 4. 412 ; Icon. 4. 243. pl. 198.-Redt. Faun. Aust. 102.

Head black, smooth and convex, with a minute fovea on each side in front at the base of the antennæ, the latter fuscous black with two joints at the base testaceous, palpi testaceous, with the penultimate joint fuscous black. Thorax subquadrate, broad, the width rather greater than the length, sides rounded, narrowed behind, but the posterior angles rounded and very slightly elevated, disk very convex, smooth and shining, ferruginous red, immaculate, the dorsal line faint and met in front by a curved transverse stria, base with a moderately deep fovea on each side, close to the posterior margin. Elytra wider than the thorax, 
the shoulders rounded, sides nearly straight, slightly emarginate before the apex, testaceous, having a blue-black or cyaneous patch spread over each behind the middle, only leaving the apex, the exterior margins and the suture narrowly edged with testaceous, disk convex, striated, the striæ impunctate; body beneath black, legs reddish testaceous, femora rather obscure. Length 2 lines.

This species is for the first time introduced into the British fauna on the authority of two specimens captured by the Rev. H. Clark, in the Isle of Sheppey, between Sheerness and Queenborough, in May 1853.

** Tarsi antici maris articulo penultimo levitèr emarginato, cordato.

5. S. consputus : elongatus, niger ; thorace rufo-piceo, cordato, posticè utrinque foveolato, angulis posticis rectis; elytris testaceis, striatis, plagâ oblongâ nigro-piceâ ; antennarum basi pedibus abdominisque apice flavis.

Carabus consputus, Dufts. Faun. 2. 148.

Trechus consputus, Sturm, D. F. 6.71.pl. 149.-Steph. Mand. 1. 173, et Manual, p. 49.

Acupalpus consputus, Dej. Spec. 4. 443 ; Icon. 4. 258. pl. 199. Stenolophus consputus, Erichson, Käfer, 61. - Heer, Faun. Helv. 116.-Redt. Faun. Aust. 102.

Elongate, rather narrow. Head black, with two deep foveæ between the eyes; mouth, palpi and two joints at the base of the antennæ testaceous, the rest fuscous black. Thorax pitchy red, very little wider than the head, slightly rounded below the anterior angles, much contracted behind, posterior angles right angles, disk very convex, base with a deep fovea on each side. Elytra oblong, rather straight in front, with the humeral angles only a little rounded and elevated, sides somewhat parallel, disk convex and deeply striated, yellowish testaceous, having a large oblong bluish-black patch behind, extending more or less upwards but leaving the margins and suture always pale; underside of the body black, apex of the abdomen and legs pale testaceous. Length 2 lines.

This species may be readily distinguished from its allies by its more elongate and narrow form, by its cordate thorax, which is likewise obliquely contracted behind and has distinct right angles; and by the long parallel-sided elytra, which are of a paler colour and have merely an oblong dark patch behind.

An individual of this species (with one of Bembidium littorale) is placedin the Fabrician collection, as Erichson hasinformed us, under 
the name dorsalis, but the Fabrician description of the latter insect can refer only to the species to which we have given that name.

It is very local: "Battersea fields and Old Brompton, sparingly," Mr. Waterhouse. "Taken rather plentifully in a gravelpit near Windsor," Mr. Griesbach (as quoted by Mr. Stephens). In May 1849, I procured a fine series on the banks of a stream in Herringstone marsh near Dorchester.

6. S. dorsalis : oblongus, rufo-testaceus; thorace subquadrato, posticè utrinque foveolato, angulis posticis subrotundatis, disco plerumque fusco; elytris striatis, plagâ oblongâ posteriore nigrâ; antennarum basi pedibusque testaceis.

Carabus dorsalis, Fab. Mant. 1. 205.-Fab. S. EI. 1. 208.

Harpalus dorsalis, Gyll. Ins. Suec. 2. 164.

Trechus dorsalis, Sturm, D. F. 6. 72. pl. 149.-Steph. Mand. I. 167, et Manual, p. 48.

Acupalpus dorsalis, Dej. Spec. 4. 446; Icon. 4. 260. pl. 200.

Stenolophus dorsalis, Erichson, Käfer, 61.-Heer, Faun. Helv. 116.-Redt. Faun. Aust. 102.

Trechus parvulus, Steph. Mand. 1. 167, et Manual, p. 48.

Oblong, rather wide. Head black, smooth and shining, with two obsolete foveæ in front, external edge of the mandibles, base and apex of the palpi and basal joint of the antennæ testaceous, penultimate joint of the palpi and rest of the antennæ pitchy. Thorax reddish testaceous with a dusky patch in the centre of the disk, sometimes almost or quite covering it and leaving the edges only pale and sometimes almost obsolete, subquadrate, the breadth greater than the length, sides slightly rounded, posterior angles somewhat rounded, disk rather flattish, with a fine dorsal furrow and an impressed fovea at the base close to each angle. Elytra oblong, broad, sides almost straight, finely striated, interstices flat, testaceous, with a blue-black oblong patch behind, in some examples interrupted at the suture, in others covering the entire disk except the shoulders, in others again more or less obsolete; body beneath black, legs pitchy or pale testaceous. Length $1 \frac{2}{3}$ line.

This insect, which somewhat resembles meridianus, cannot be confounded with it. It is much broader; the thorax especially is shorter and broader, and not like that of meridianus distinctly narrowed behind, and is always more or less rufous with a dusky patch in the middle. Stephens has given as its localities, "Wandsworth Common and Copenhagen Fields at the roots of grass on gravelly banks by the sides of ponds;" and "marshes near Fakenham." I am indebted to Mr. Hadfield for a fine series of varieties, which he procured from a gravel-pit on Stapleford Common near 
Newark, where he has taken them both in spring and autumn, among grass and rushes. It is also stated to have been taken at Raehills, Dumfriesshire, by the Rev.W.Little; and near Paisley. The Rev. Mr. Jarman captured it abundantly in May 1853 near the railway bridge that crosses the lode in Holme Fen, Hunts.

7. S. meridianus : oblongus, niger; thorace posticè angustato, utrinque foveolato punctatoque, angulis posticis obtusis; elytris striatis, basi suturâ pedibusque testaceis.

Carabus meridianus, Linn. F. S. 797.-Fab. S. El. 1. 206.

Harpalus meridianus, Gyll. Ins. Suec. 2. 165.

Acupalpus meridianus, Dej. Spec. 4. 451; Icon. 4.265. pl. 200. Trechus meridianus, Steph. Mand. 1. 170, et Manual, p. 49.

Stenolophus meridianus, Erichson, Käfer, 62.-Heer, Faun. Helv. 117.

Trechus suturalis, Steph. Mand. 1. 168, et Manual, p. 49.

Oblong. Head and thorax shining black, very glossy; palpi and antennæ pitchy testaceous, base of the latter pale. Thorax broad in front, and about equal to the length, and rounded below the angles, obliquely narrowed behind, posterior angles obtuse, dorsal furrow entire, having on each side at the base a large punctured fovea. Elytra oblong, very slightly widest behind the middle, rather convex and distinctly striated, black, with the base and the suture testaceous; underside black, legs testaceous. Length $1 \frac{2}{3}$ line.

$T$. suturalis of the Stephensian collection belongs to this common species.

8. S. derelictus: oblongus, nigro-piceus; thorace quadrato, posticè utrinque foveolato, angulis posticis subrotundatis; elytris subtilitèr striatis; antennarum basi pedibusque pallidè testaceis.

Oblong, pitchy black. Head with a minute fovea on each side in front, palpi and two joints at the base of the antennæ testaceous. Thorax reddish pitchy, with its margins testaceous, broad and nearly quadrate, sides rounded and very slightly narrowed behind, posterior angles somewhat rounded, very moderately convex, the base depressed, having an impunctate fovea on each side. Elytra about half as wide again as the thorax, shoulders somewhat elevated, sides almost straight or very slightly widest behind the middle, the apex distinctly emarginate, disk moderately convex, finely striated, the striæ impunctate; underside black, legs pale testaceous. Length $1 \frac{2}{3}$ line.

This apparently unique insect is about the size of $\mathbf{S}$. dorsalis, 
but rather wider. It is very nearly allied to S. brunnipes, Sturm (a species of which no British example has hitherto occurred), but it is broader, paler, less convex, the base of the thorax depressed, and the basal foveæ are entirely smooth and impunctate, characters which appear to disconnect them. The specimen from which I have taken my description is however a $q$. It was captured near London, probably at Plumstead, by Mr. F. Smith of the British Museum, who kindly gave it to me. It was returned to me from Paris as a species of Stenolophus unknown there.

9. S. flavicollis : oblongus, capite nigro, thorace rufo-testaceo, lato subquadrato, posticè utrinque foveolato, angulis posticis subrotundatis; elytris striatis, fusco-testaceis subcyaneis, margine suturấque rufo-testaceis ; antennarum basi pedibusque testaceis.

Trechus favicollis, Sturm, D. F. 6. 87. pl. 151.

Stenolophus favicollis, Erichson, Käfer, 63.-Heer, Faun. Helv.

117.-Redt. Faun. Aust. 103.

Acupalpus nigriceps, Dej. Spec. 4. 453; Icon. 4. 267. pl. 200.

Oblong, broad. Head black and convex, with the usual small foveæ in front; mandibles, palpi and basal joint of the antennæ testaceous, apex of the mandibles; penultimate joint of the palpi and the rest of the antennæ brownish. Thorax reddish testaceous, subquadrate, broad (Pl. II. f. 5), a little rounded at the sides, scarcely narrowed behind, posterior angles rather rounded, but not elevated, disk moderately convex, smooth, with a faint dorsal line intersected by a fine transverse impression in front, base with a neatly sculptured fovea near each angle. Elytra pitchy red, or reddish testaceous, with an obscure cloud on each, the suture always paler testaceous, broader than the thorax, not narrowed in front, but with the shoulders wide and rounded, sides almost parallel, disk convex and finely striated; legs pale testaceous. Length $1 \frac{1}{2}$ line.

This insect is entirely distinct from $T$. flavicollis, Steph., which belongs to the next species. The thorax is much wider and not narrowed behind as in that insect, the elytra are also wider and more parallel and not at all contracted in front. It was first captured in England by Mr. Dale several years ago, who obtained two specimens from the neighbourhood of Lymington. I secured a fine series in a marshy piece of ground near Shanklin and Luccombe in the Isle of Wight in the months of April and May $1847-48$.

10. S. Iuridus : oblongus; capite fusco-testaceo, thorace testaceo, 
subquadrato, posticè subangustato, utrinque foveolato, angulis posticis obtusis ; elytris striatis, fusco-testaceis, margine suturâque pallidioribus ; antennarum basi pedibusque testaceis.

Acupalpus luridus, Dej. Spec. 4. 454 ; Icon. 4. 268. pl. 201. Stenolophus luridus, Redt. Faun. Aust. 103.

S. exiguus, var., Erichson, Käfer, 63.

Trechus favicollis, Steph. Mand. 1. 168, et Manual, p. 48.

T. nitidus, Steph. Mand. 5. 384, et Manual, p. 49.

Oblong. Head pitchy or fuscous testaceous, convex, with the usual impressions on each side between the antennæ, which are pitchy brown with two joints at the base pale testaceous. Thorax testaceous, much narrower than in flavicollis (Pl. II. f. 6), a little rounded below the anterior angles, narrowed behind, delicately margined and the margin a little elevated at the posterior angles which are obtuse, disk convex, with a fine dorsal line and a deep fovea on each side at the base. Elytra rusty brown or pitchy testaceous, more or less obscure, with the suture and margins paler, oblong, narrowed in front, shoulders rounded, sides very gradually and obliquely widening till behind the middle, moderately convex, evenly and finely striated; breast and abdomen brownish black; legs pale testaceous. Length $1 \frac{1}{3}$ line.

Not very abundant, but widely distributed; Wandsworth Common; Hampstead Heath; Weybridge; Ripley; Hastings ; Isle of Wight. "Moffat hills," Rev. W. Little. It is also included among the Irish species.

11. S. exiguus: oblongus, nigro-piceus; thorace subquadrato, posticè subangustato, utrinque foveolato, angulis posticis obtusis ; elytris striatis, antennarum basi pedibusque piceotestaceis.

Acupalpus exiguus, Dej. Spec. 4. 456 ; Icon. 4. 270. pl. 201. Stenolophus exiguus, Erichson, Käfer, 63.-Redt. Faun. Aust. 103.

This rare little species is somewhat smaller than the preceding. It is uniformly shining pitchy black, and independent of the difference of colour, it appears to have constant characters to distinguish it from the foregoing species. The form is narrower and more depressed. Head small and round; antennæ pitchy black, two joints at the base together with the mouth and palpi pitchy testaceous. Thorax narrower, more contracted behind, posterior angles obtuse, disk with the usual dorsal furrow, base with a fovea on each side. Elytra narrower in front but with the shoulders prominent, rather widest behind the middle, but the 
sides not rounded, disk more depressed, finely striated; legs pitchy testaceous. Length $1 \frac{1}{4}$ line.

This insect was first discovered in England by Mr. S. Stevens, who captured a few specimens on Bury hill near Arundel; a single example was taken by Mr. Wollaston near Luccombe in the Isle of Wight; and I subsequently secured a series from beneath rejectamenta on the sands in Pegwell Bay near Ramsgate in Feb. 1849.

\section{Genus 44. BRADYCELLUS, Erichson.}

Mentum dente medio acuto. Ligula apice medio sinuata; paraglossis membranaceis, acuminatis, ligulam paululùm superantibus. Palpi articulo ultimo fusiformi, apice subacuminato. Mandibulæ breves, acutiuscula. Labrum transversum, truncatum. Tarsi antici maris articulis quatuor dilatatis, primo subquadrato, reliquis obcordatis, singulis subtùs biseriatìn pectinato-setosis; intermedii in utroque sexu simplices.

1. B. placidus : oblongus, rufo-testaceus; thorace subquadrato, posticè subangustato, utrinque foveolato punctatoque, disco plerumque infuscato; elytris striatis, testaceis, maculâ oblongâ juxta suturam nigro-piceấ; antennarum basi pedibusque testaceis.

Harpalus placidus, Gyll. Ins. Suec. 4. 453.

Acupalpus placidus, Dej. Spec. 4. 441 ; Icon. 4. 256. pl. 199.Heer, Faun. Helv. 118.

Trechus placidus, Steph. Mand. 5. 384, et Manual, p. 50.

Bradycellus placidus, Erichson, Käfer, 65.-Redt. Faun. Aust. 103.

Harpalus vespertinus, Gyll. Ins. Suec. 2. 162.

Head large, pitchy, convex, the sides punctured behind the eyes, which are large and prominent; palpi and three joints at the base of the antennæ testaceous. Thorax ferruginous, with a dark blotch in the middle, wide and rounded in front below the angles, obliquely narrowed behind, disk moderately convex, having a fine dorsal line which is met in front by a transverse curved depression on which are several small punctures, base punctured, and with a large punctured fovea on each side. Elytra testaceous, with a narrow lanceolate dark stripe on each near the suture, the latter being always pale, oblong-ovate, shoulders a little rounded, sides rather widest about the middle, evenly striated, striæ deepest next the suture; legs pale testaceous. Length 2 lines. 
Not common; but found in the marshes about Whittlesea Mere and in the Cambridgeshire fens. "Banks of the Thames and Stockton-on-Tees," Mr. Stephens. "Dunston in June," J. Hardy.

2. B. cognatus : oblongus, subpubescens, nigro-piceus; thorace subquadrato, posticè subangustato, utrinque foveolato punctatoque, angulis posticis subrotundatis; elytris piceoferrugineis, striatis, maculâ magnâ oblongâ nigro-piceâ; antennarum basi tibiisque rufo-testaceis.

Harpalus cognatus, Gyll. Ins. Suec. 4. 455.

Acupalpus cognatus, Dej. Spec. 4. 440 ; Icon. 4. 255. pl. 199.

This insect is nearly allied to the preceding, but is smaller, darker and very finely pubescent. Head-black, palpi and antennæ pitchy, apex of the former and the basal joint of the latter red. Thorax pitchy black or black with the margins narrowly and the base more broadly obscure testaceous, subquadrate, a little narrowed behind, posterior angles rather more rounded than in placidus, the dorsal furrow terminating in front in a depressed space extending transversely to the anterior angles and carrying numerous punctures, the base also punctured and with a punctured fovea on each side, as in the allied species. Elytra pitchy black, with the suture, the shoulders and the lateral margins ferruginous, more or less pitchy, sometimes reddish testaceous with a large dark cloud covering the hinder portion and extending more narrowly upwards, disk convex, very finely pubescent, rather less deeply striated and the sides less dilated behind than in placidus; legs pitchy black, tibiæ reddish testaceous. Length 2 lines.

This is peculiarly a mountain species and has never occurred in the south. In Wales, Yorkshire and other northern counties, as well as in Scotland, it is taken upon the high moors. Stephens made a mistake when he recorded its capture near London; the specimen which he mistook for this insect is an immature meridianus. Abundant on Midgeley Moor, \&c., Yorkshire; in profusion on Griben Oernant, Moel y Gamelin and other moors near Llangollen. Mr. Haliday has captured a single specimen on the hills near Belfast. "Near Edinburgh; Renfrewshire, Berwickshire." Murray's Catalogue.

3. B. fulvus : oblongo-ovatus, rufo-piceus; thorace subquadrato, posticè utrinque foveolato punctatoque, angulis posticis obtusis ; elytris striatis, striis externis obsoletè punctulatis ; antennis pedibusque testaceis.

Carabus fulvus, Marsham, Ent. 456. 
Trechus fulvus, Steph. Mand. 1. 167, et Manual, p. 49.

T. pallidus, Steph. Mand. 1. 169.

Acupalpus harpalinus, Dej. Spec. 4.471 ; Icon.4.274.pl.201.

- Heer, Faun. Helv. 118.

Bradycellus harpalinus, Redt. Faun. Aust. 103.

Trechus brunnipes, Steph. Manual, p. 49.

Head convex, smooth, with the usual impressions in front; palpi and antennæ testaceous. Thorax nearly quadrate, a little narrowed behind and with the hinder angles obtuse, more rarely inclined to right angles, base usually broad and almost truncate, the dorsal furrow strongly marked and met in front by a depression curved so as to enclose a triangular raised space above it, base with a large punctured fovea on each side. Elytra oblongovate, sides very slightly rounded in some examples, but more ovate and more dilated behind the middle in others, convex, moderately striated, some of the exterior striæ obsoletely punctured; legs pale testaceous. The colour is very variable, sometimes reddish testaceous or fulvous, pitchy red, or pitchy brown or ferruginous with an obscure dusky oblong dash on each elytron, the paler colours not being always indicative of a less degree of maturity. It is also very variable in size. Length $1 \frac{3}{4}-2 \frac{1}{4}$ lines.

$T$. brunnipes, Steph., is a dark individual of this species. The true T. brunnipes, Sturm, is not found in Britain and is altogether a different insect.

This species is very abundant and generally distributed.

4. B. collaris : oblongo-ovatus, rufo-ferrugineus; thorace subquadrato, posticè subangustato, utrinque foveolato punctatoque, angulis posticis obtusis; elytris striatis; antennarum basi pedibusque testaceis.

Carabus collaris, Payk. Faun. 1. 146.

Harpalus collaris, Gyll. Ins. Suec. 2. 166.

Acupalpus collaris, Dej. Spec. 4. 472 ; Icon. 4.275. pl.202.Heer, Faun. Helv. 118.

Bradycellus collaris, Erichson, Käfer, 65. - Steph. Manual,p. 50.

- Redt. Faun. Aust. 103.

This species is about two-thirds the ordinary stature of fulvus, and very small examples of that insect are liable to be confounded with it. It is oblong-ovate, reddish ferruginous with the thorax usually paler. Head smooth and very convex with a small round fovea on each side in front; antennæ pitchy with three joints at the base pale; eyes black. Thorax nearly quadrate, more convex, base with two deep fover punctured within and on the edges, the 
hinder angles obtuse. Elytra oblong-ovate, not so broad in front nor so dilated behind the middle as in fulvus, but more convex, distinctly striated, the striæ wholly impunctate; underside of the head and thorax rusty red, breast and abdomen pitchy black; legs pale testaceous. Length $1 \frac{2}{3}$ line.

The insect described by Sturm under the name collaris is thought by Erichson to belong to the foregoing species; at any rate the descriptions given by Sturm do not correspond with the insect before us. It is a mountain species and is found upon the high moors in North Wales, Yorkshire, Lancashire and Scotland; less frequent in more southern districts.

5. B. similis: oblongo-ovatus, piceus; thorace subquadrato, posticè utrinque foveolato, foveis punctatis ; elytris striatis, striis externis obsoletè punctatis ; antennarum basi pedibusque testaceis.

Acupalpus similis, Dej. Spec. 4. 474; Icon. 4. 277. pl. 202.

Bradycellus similis, Erichson, Käfer, 694.-Redt.Faun.Aust.103.

Harpalus collaris, var. b, Gyll. Ins. Suec. 4. 455.

Trechus ruficollis, Steph. Mand. 1. 168, et Manual, p. 48.

Smaller than collaris, pitchy black, with the thorax sometimes and the suture always pitchy red, palpi and base of the antennx pale. Thorax subquadrate, much shorter and wider than in collaris, a little rounded in front below the angles, very slightly narrowed behind so that the base appears broad, the posterior angles less obtuse, base with a deep punctured fovea on each side. Elytra oblong-ovate, broadest behind the middle, striated, some of the external striæ very obsoletely punctured; underside black; legs pitchy or rusty red. Length $1 \frac{1}{2}$ line.

As the name ruficollis had been previously employed, I have adopted that which Dejean gave to the species. The insect is extremely abundant on sandy and moory commons where heather grows all over the kingdom.

\section{Genus 45. TRECHUS, Clairville.}

Mentum dente medio integro, vel emarginato. Ligula apice rotundata; paraglossis linearibus, eam multùm superantibus. Palpi articulo ultimo penuitimo minore, conico, acuto. Mandibulæ prominula, acuta. Labrum transversum, apice plus minus emarginatum. Tarsi antici maris articulis duobus dilatatis triangularibus, introrsims dilatatis.

1. T. discus : oblongus, rufo-testaceus ; thorace cordato, angulis posticis acutis; elytris subtilitèr punctato-striatis subpu- 
bescentibus, maculâ communi posticâ fuscâ; antennis pedibusque testaceis.

Carabus discus, Fab. S. El. 1.207.-Dufts. Faun. 2. 171.

Trechus discus, Sturm, D. F. 6. 80.-Dej. Spec. 5. 4 ; Icon. 4. 287. pl.203. -Erichson, Käfer, 120.-Heer, Faun. Helv. 119. Blemus discus, Steph. Manual, p. 50.

B. unifasciatus, Steph. Mand. 1. 172.

Oblong, testaceous red, subpubescent. Head with a deep oblong impression on each side, eyes black and prominent. Thorax cordate, much narrowed behind, posterior angles acute, disk with a deep dorsal furrow and a transverse impression and two foveæ at the base. Elytra oblong, rounded at the shoulders, finely punctate-striated, with two impressions on the third stria, interstices obsoletely punctulated and pubescent, disk with a common fuscous or blue-black patch behind the middle; legs paler testaceous. Length $2 \frac{1}{4}$ lines.

Frequents humid places in Norfolk, Suffolk, Cambridgeshire and midland counties, and in the London district. Meadows by the Trent near Newark; Vale of Towey; islands of the Ouse in Bedfordshire, \&c.

2. T. micros : elongatus, testaceus; thorace subcordato, angulis posticis rectis; elytris subparallelis, subtilitèr punctatostriatis, interstitiis subtilissimè punctulatis, pubescentibus ; antennis pedibusque testaceis.

Carabus micros, Herbst, Archiv, 142. 60.

Trechus micros, Sturm, D. F. 6. 82.-Dej. Spec. 5. 5 ; Icon. 4. 289. pl.203.-Erichson, Käfer, 120.-Heer, Faun. Helv. 119.

Blemus micros, Curtis, Ent. pl. 310.-Steph. Manual, p. 50.

Carabus rubens, Dufts. Faun. 2. 112.

Blemus rubens, Steph. Mand. 1. 172.

Narrower and more elongate than the preceding species and of a duller testaceous colour. Head dusky, rather depressed, with a fovea on each side, palpi and antennæ testaceous red. Thorax subcordate, rounded at the anterior angles and rather dilated, obliquely narrowed behind, posterior angles right angles, base with two foveæ. Elytra oblong, somewhat parallel, faintly striated, pubescent, with two impressions, one before and the other behind the middle, interstices very minutely and densely punctulated, each elytron with a dusky cloud towards the apex; legs testaceous. Length 2 lines.

Local. "Lambeth, Chelsea and Hackney marshes; Windsor; Thruxton, Hants ; Carlisle ; the Vale of Towey in South Wales; banks of the Trent, near Newark;" Berwickshire; "Falkirk, Paisley, Mull, Glasgow." Murray's Catalogue. 
3. T. longicornis : elongatus, rufo-brunneus ; thorace cordato, posticè utrinque absoletè foveolato, angulis posticis rectis ; elytris subparallelis, striis tribus dorsalibus distinctis, externis obsoletis; antennis pedibusque testaceis.

\section{Sturm, D. F. 6. 83. pl. 151.-Heer, Faun. Helv. 119.}

Blemus longicornis, Steph. Mand. 1. 172, et Manual, p. 50.

Trechus littoralis, Dej. Spec. 5. 7; Icon. 4. 290. pl. 103.

Elongate, narrow, reddish brown. Head obscure black, with two curved impressions approximating in front, and forming an elevated ridge on each side behind the eyes, the latter rather small; palpi and antennæ testaceous. Thorax separated from the hinder part of the body by a short collar or neck, cordate, posterior angles right angles, disk with the usual dorsal furrow terminating before and behind in a transverse impression, base with two foveæ. Elytra somewhat parallel, disk flattish and very finely striated, the three strix nearest the suture rather more distinct, the sutural one disappears just before the extremity, the second and third reach to the apex, just before which they form a curve, the fourth stria disappears behind the middle, and the remainder become obsolete before they reach it, on the third stria there is an impression a little behind the middle and another near the apex; legs testaceous. Length $1 \frac{3}{4}$ line.

This rare species has hitherto occurred but in one locality in Britain, having been taken from under rejectamenta at the Dudden Sands near Broughton, Lancashire, in June.

4. T. rubens: oblongus, piceus; thorace subquadrato, posticè utrinque foveolato, angulis posticis acutis; elytris oblongoovatis, violaceo-micantibus, punctato-striatis, striis externis obsoletis; antennis pedibusque testaceis.

Carabus rubens, Fab. S. El. 1. 187.

Bembidium paludosum, Gyll. Ins. Suec. 2. 34 .

Trechus paludosus, Sturm, D. F. 6. 89.-Dej. Spec. 5. 8; Icon. 4. 292. pl. 203.-Heer, Faun. Helv. 120.

Blemus paludosus, Steph. Mand. 1. 171, et Manual, p. 50.

Oblong, pitchy or pitchy red, shining. Head depressed, with a deeply impressed stria on each side between the eyes, palpi and antennæ red. Thorax subquadrate, sides rounded in front, narrowed behind, posterior angles acute and rather prominent, disk rather convex, the central line terminated in front by a slight impression, the base with two deep foveæ. Elytra oblongovate, sides wider and more rounded behind the middle, disk a little depressed in front, having a bluish or cyaneous reflection, 
punctate-striated, the punctured striæ rather obsolete on the sides, the outer margins with a few larger impressions behind the shoulders; body beneath pitchy black, with the apex of the abdomen pale; legs red. Length $2 \frac{3}{4}$ lines.

For restoring the Fabrician name to this insect, $I$ have the authority of Erichson, who informs us that he found it so labelled in the Fabrician collection. It occurs in the north of England and in Scotland, and more rarely in Ireland.

5. T. lapidosus : rufo-testaceus, nitidus, capite interdùm piceo, oculis nigris ; thorace subquadrato, posticè utrinque foveolato, angulis posticis acutis ; elytris punctato-striatis punctisque duobus impressis; antennis pedibusque pallidis. (Pl. II. f. D, Pl. III. f. 3.)

Blemus lapidosus, Dawson, Ann. Nat. Hist. 3. 214 (1849).

B. pallidus, Steph. Manual, p. 50.

Above reddish testaceous, paler beneath. Head sometimes pitchy, oblong depressed, with a deep longitudinal impression on each side behind the eyes; the latter black and depressed, palpi and antennæ pale testaceous. Thorax subquadrate, sides margined, rounded below the anterior angles, obliquely narrowed behind, posterior angles acute and prominent, disk flattish with an impressed dorsal line, base depressed, with two wide foveæ. Elytra much depressed, punctate-striated, the third interstice with two deeper impressions; legs pale testaceous. Length $2 \frac{3}{4}$ lines.

Very local ; near Ventnor, Isle of Wight; South Shields and Berwick-upon-Tweed. A single specimen has been taken by Mr. Haliday on the shore at Holywood, in Ireland.

6. T. incilis: subtùs niger, abdominis apice testaceo, suprà nigro-piceus; thorace subquadrato, posticè utrinque foveolato, angulis posticis acutis; elytris oblongo-ovatis, striis quatuor dorsalibus abbreviatis in singulo impressis; antennarum articulo 2,3 et 4 basi nigris, reliquis, palpis pedibusque testaceis. (Pl. II. f. C.)

Dawson, Ann. Nat. Hist. 3. 213 (1849).

Oblong-ovate, pitchy black. Head with two deep frontal impressions, with an elevated ridge between them; antennæ reddish testaceous, the second, third and fourth joints ringed with black. Thorax subquadrate, sides rounded and acutely margined, contracted behind, posterior angles acute, disk rather 
convex, with the dorsal line entire, and two deep foveæ nearly covering the base. Elytra oblong-ovate, with a cyaneous reflection, rather convex, the disk of each furnished with three coarse abbreviated striæ and a fourth interrupted and somewhat obsolete, sides and apex smooth, with four or five impressions within the margins, near the humeral angles; body beneath shining black, with the tip of the abdomen broadly testaceous, legs red. Length $2 \frac{1}{4}$ lines.

I captured a pair of this remarkable species at Whittlesea Mere, in July 1847.

7. T. minutus : rufo-piceus; thorace transverso, posticè utrinque foveolato, angulis posticis obtusis; elytris oblongo-ovatis, striis quatuor dorsalibus distinctis, externis obsoletis; antennis pedibusque testaceis.

Carabus minutus, Fab. S. El. 1. 210.

Trechus minutus, Steph. Mand. 1. 169.-Erichson, Käfer, 121. -Heer, Faun. Helv. 120.

Carabus tempestivus, Panz. Faun. 73. 6.

Bembidium 4-striatum, Gyll. Ins. Suec. 2. 31 .

Trechus rubens, Clairv. Ent. Helv. 2. 26.-Sturm, D. F. 6. 97. -Dej. Spec. 5. 12 ; Icon. 4. 296. pl. 204.

T. aquaticus, fuscipennis et tristis, Steph. Manual, p. 49.

T. lavis, Steph. Mand. 5. 394.

Var. $\beta$. elytris stria tertia punctis duobus impressis.

C. 4-striatus, Dufts. Faun. 2. 185.

Trechus obtusus, Erichson, Käfer, 122.

Variable in colour, pitchy red or ferruginous, the head usually pitchy black, sometimes also the thorax with the margins reddish. Head with a deep elongate impression on each side, between which and the eye is an elevated fold; the parts of the mouth and the antennæ testaceous. Thorax transverse, the breadth in front greater than the length, the sides rounded below the anterior angles, more or less obliquely narrowed behind, posterior angles obtuse, disk very smooth and shining, with a deep dorsal furrow terminating before and behind in an evident depression, the base with a large fovea on each side near the angle. Elytra oblong-ovate, much broader than the thorax, sides rounded and dilated behind the middle, depressed, each with four striæ next the suture, the exterior ones more or less obsolete and not reaching the apex; the first next the suture forms a bend at the apex, and passing along the margin is carried upwards beyond the next three, presenting the appearance of a regular curve; under a strong magnifying power the striæ appear obsoletely punctured 
in some examples, but in others perfectly smooth, and generally there are two distinct impressions on the third stria; legs testaceous. Length $1 \frac{3}{4}$ line.

Extremely common and abundant everywhere.

\section{(Epaphius, Leach.)}

8. T. secalis: ferrugineus; thorace cordato subgloboso, angulis posticis rotundatis; elytris ovatis, striis quinque dorsalibus punctatis, externis obsoletis; pedibus pallidè testaceis.

Carabus secalis, Payk. Faun. 1. 146.-Dufts. Faun. 2. 62. Bembidium secale, Gyll. Ins. Suec. 2. 36 .

Trechus secalis, Sturm, D. F. 6.96.-Dej. Spec. 5. 24 ; Icon. 4. 310. pl.206.-Erichson, Käfer, 122.-Heer, Faun. Helv. 123. Epaphius secalis, (Leach, MSS.), Sam. Ent. Comp. p. 149.Steph. Mand. 1. 172, et Manual, p. 50.

Ferruginous, shining. Head with a deep furrow on each side and an elevated fold on which is a round puncture close to the eyes, which are black, antennæ pale testaceous. Thorax cordate, globose, much narrowed behind and so rounded as to leave scarcely any posterior angles, convex, very glabrous and shining, with an impressed dorsal line and with two fover at the base. Elytra ovate, shoulders rounded, the sides widest behind the middle, each wing-case with five strix next the suture deeply striated till behind the middle, the strix exterior to these slightly marked, the apex and sides smooth, the third stria nearest the suture with two larger impressions, and the margins with a few just below the shoulders; legs pale testaceous. Length $1 \frac{3}{4}$ line.

This insect is found abundantly in many parts of England, but is rather local : on the coast of Norfolk and the banks of the Humber; midland counties; near Newark; north of England; Berwickshire; and in South Wales.

\section{Genus 46. Ä̈PYS, Leach.}

Mentum dente medio obtuso. Ligula parva, paraglossis tenuibus setisque duabus mediis armatis. Palpi maxillares maxillis vix longiores, articulo ultimo penultimo breviore illo attenuato, labiales articulo ultimo penultimo longitudine aquali attenuato. Mandibulæ porrecta, intùs acutè tridenticulatæ, denticulis distantibus. Labrum profundè emarginatum. Tarsi anteriores articulo penultimo subtùs spiná incurvâ armati, singulis subtùs pubescentibus.

1. A. marinus : apterus, depressus, pallidè jlavus, subpubescens; 
thorace cordato, angulis posticis subrectis; elytris oblongis, subparallelis, obsoletissimè striatis punctisque tribus vel duobus impressis.

Cicindela marina, Ström. Act. Hafn. (1783) p. 63. f. 8. Aëpus fulvescens, (Leach, MSS.) Sam. Ent. Comp. p. 149.Curtis, Ent. pl. 203.-Steph. Mand. 1. 174, et Manual, p. 51. Trechus fulvescens, Dej. Spec. 5. 27 ; Icon. 4. 311. pl. 206.

Wingless, very depressed, subpubescent, pale ochreous yellow, paler beneath. Head very large, with a deep curved impression on each side; eyes minute and black. Thorax cordate, truncate in front, sides obliquely narrowed to the base, which is contracted and has two obsolete foveæ, hinder angles not quite rectangular, but more or less obtuse. Elytra oblong, humeral angles rounded, sides rather parallel, disk irregularly and more or less obsoletely punctulated and striated, generally with two or three more distinct impressions; legs pale. Length 1 line.

"Taken in plenty on the southern coast of Devonshire, beneath stones at the mouths of the rivers Tamar and Yealm; and at Tamarton, Bantham and Kingsbridge." Dr. Leach. Berwickupon-Tweed. "Ballyhuish Ferry, Scotland." Mr. Curtis. Found in great abundance also by my friend Mr. Adam White, at South Queensferry, at low water, in the interstices of the stratified sandstone into which silt had been washed by the tide. "Strangford Lough, Ireland." Mr. Haliday.

2. A. Robinii : apterus, depressus, pallidè flavus, subpubescens ; thorace cordato, angulis posticis subrotundatis; elytris oblongo-ovatis, lævigatis, punctisque tribus vel duobus impressis.

Trechus Robinii, Lab. Ann. Soc. Ent. (2nd series) 7. 35. pl. 2.

This insect, which bears a close affinity to the preceding, differs in the following particulars. The posterior angles of the thorax are more rotundate; the elytra are more narrowed and rounded in front and the sides are distinctly rounded instead of being parallel; the mandibles are less prominent; and the spine beneath the penultimate joint of the anterior tarsus is shorter and less curved; the entire upper surface is likewise more glabrous and shining. Mons. Laboulbène, in the seventh volume of the "Annales de la Société Entomologique de France," has fully described the species from examples captured near Boulogne. I have received specimens from Scotland of both insects, which will probably be found mixed up in collections. Mr. Wollaston 
took three or four in my presence from a salt marsh in the Isle of Portland, which correspond with the present insect; and my friend Mr. Guyon secured a single example on the sea-shore at Ventnor.

\section{Subfam. 5. Bembidides, Westwood.}

The genus Bembidium, first established by Latreille, is now generally re-adopted to comprehend that little group of insects of semi-aquatic habits, which, upon the authority of Megerle and Ziegler, had been subdivided under the names Tachys, Notaphus, Peryphus, Lopha, Leja, Tachypus and Blemus, to which have been added by our British entomologists Cillenus, Ocys, Philocthus and Lymnaum, because the characters upon which these subdivisions are based were considered insufficient to warrant the establishment of distinct genera. Of these, Blemus, Lymnoum and Cillenus are represented by solitary types of a very remarkable character, which, from their general habit of passing a considerable portion of their existence (more especially the insect which represents the latter genus) in a state of submersion, nearly approximate to Aëpys, and form, in fact, a valuable connecting link between the Trechi and the true Bembidia. Between Cillenus and the other Bembidia no material variation of internal structure is observable, but the insects which represent Blemus (Pl. III. f. 1) and Lymnaum (Pl. III. f. 2) differ from them in several particulars, and I have consequently ventured to retain them as distinct genera. It is questionable, indeed, whether they might not, with equal propriety, be placed among the Trechi, more especially the remarkable species which represents the genus Blemus, as it more nearly resembles the typical characters of Trechus in the ligula, paraglossa and palpi; the apical joint of the labial and maxillary palpi, though shorter than the preceding, being more than double the length of the corresponding one in Bembidium. In fact, M. Jacquelin-Duval has excluded it from his monograph on the European Bembidia on those grounds.

\section{Genus 47. BLEMUS, Ziegler.}

Mentum lateribus valdè rotundato-dilatatis, dente medio integro. Ligula lata membranacea apice subrotundata; paraglossis linearibus ligulam multùm superantibus. Palpi maxillares articulo secundo margine externo inflato, penultimo elongato incrassato paululùm securiformi, labiales articulo penultimo subovali, ultimis gracillimis subelongatis at penultimis brevioribus. Maxillæ graciles, acuta, lobo interno intùs spinuloso- 
ciliata, externo biarticulato, articulo secundo dimidio breviore. Mandibulæ-arcuata, acuta, intùs in medio tridenticulata. Labrum minutum, anticè profundè emarginatum, posticè fortitèr coarctatum. Tarsi antici maris articulis duobus dilatatis, primo triangulari, secundo abcordiformi, introrsìm dilatatis, articulo penultimo subtùs in utroque sexu spiná incurvâ armato.

1. B. areolatus: nigro-piceus, depressus; thorace oblongo-cordato posticè coarctato unistriatoque, angulis posticis acutiusculis; elytris elongatis, parallelis, subpubescentibus, plagá media rufo-ferrugined, punctato-striatis, punctisque duobus impressis; antennis basi pedibusque rufo-testaceis.

Carabus areolatus, Creutz. Ent. Ver. 115.

Bembidium areolatum, Sturm, D. F. 6. 155.-Dej. Spec. 5. 37 ; Icon. 4. 322. pl. 207.-Heer, Faun. Helv. 123.

Lymnceum areolatum, Steph. Manual, p. 52.

L. depressum, Steph. Mand. 2. 3.

Oblong, depressed, pitchy black, sometimes reddish. Head with an elongate curved impression on each side enclosing the eyes; labrum, palpi and two joints at the base of the antennæ red, the rest of the antennæ brownish. Thorax oblong, heartshaped, much contracted behind, posterior angles rather acute, disk with a deeply impressed dorsal furrow and a stria on each side at the base. Elytra depressed, elongate, sides parallel, finely pubescent, pitchy, with a red patch common to both across the middle, more or less distinct, punctate-striated, the punctured striæ effaced at the apex, the third interstice with two impressions; legs red. Length $1 \frac{1}{2}$ line.

Rare: Dudden Sands, near Broughton-in-Furness, Lancashire; and at the confluence of the Conway and Llugwy in North Wales.

\section{Genus 48. LYMNAEUM, Stephens.}

Mentum lateribus mediocritèr dilatato-rotundatis, dente medio integro. Ligula mediocris, membranacea, apice subrotundata ; paraglossis gracilibus ligulam superantibus. Palpi maxillares articulo secundo gracili, penultimo inflato, labiales articulo penultimo incrassato, ultimis subuliformibus penultimis brevioribus. Maxillæ graciles, lobo apicali intùs spinulis armato, lobo externo biarticulato, articulo basali dimidio breviore. Mandibulæ porrecta, conica, apice acuto inflexo, intùs ad 
basin sub-bidenticulate. Labrum breve, transversum, anticè subemarginatum. Tarsi antici maris articulis duobus dilatatis, articulo penultimo subtìs in utroque sexu spinâ incurvâ armato.

1. I. nigropiceum : nigro-piceum, nitidum, thorace subcordato, posticè fortitèr coarctato, utrinque profundè impresso, angulis posticis acutiusculis; elytris elongatis subparallelis, profundè striatis, punctis duobus impressis; antennis pedibusque ferrugineis.

Carabus nigropiceus, Marsham, Ent. 468.

Lymnaum nigropiceum, Steph. Mand. 2. 3, et Manual, p. 51. Bembidium sulcatulum, Chaud. Carab. p. 233 (1846).

Oblong, wingless, depressed, pitchy black, sometimes with a rusty hue. Head large, flattened, with two deep longitudinal frontal furrows; antennæ long, and, together with the palpi, rusty red. Thorax heart-shaped, wider than the head, sides rounded below the anterior angles, much contracted behind, posterior angles rather acute, base with two deeply impressed foveæ. Elytra rounded off at the shoulders, the sides almost parallel, disk depressed, deeply striated, the striæ deepest next the suture, all of them entire, with some of the marginal ones distinctly though finely punctured, the interstice between the third and fourth striæ furnished with two deep impressions, one about the centre and the other nearer the apex; legs red. Length 2 lines.

This species is rare; in 1845-6 I found it in some abundance among the fine shingle on the sea-beach at Ventnor and Steephill, Isle of Wight; since which time it had not occurred till 1852, when Mr. Guyon again procured it in the last-named locality. M. Chaudoir found it in the Crimea; and it is not a little remarkable that it has been discovered only in these two localities, so widely remote from each other.

\section{Genus 49. BEMBIDIUM, Latreille.}

Mentum dente medio integro. Ligula apice subrotundata; paraglossis sublinearibus, cam parùm supcrantibus. Palpi articulo penultimo maximo, obconico, ultimo minutissimo, acuto, subuliformi. Mandibula arcuata, acuta. I Labrum breve, transversum. Tarsi antici maris articulis duobus dilatatis, primo maximo, quadrato. 


\section{(Cillenus, Leach.)}

1. B. laterale : capite thoraceque viridi-æneis, hoc cordato posticè fortitèr coarctato; elytris elongatis, parallelis, flavo-testaceis æneo infuscatis, striatis, striis obsoletè punctatis, punctis quatuor impressis; antennis basi pedibusque pallidè testaceis.

Cillenus lateralis (Leach, MSS.), Sam.Ent. Comp.p. 148(1819). Cillenum laterale, Curtis, Ent. 200 (1828).-Steph. Mand. 2.4, et Manual, p. 52.

Bembidium laterale, Jacq.-Duv. Ann. Soc. Ent. 10. 213 (1851). B. Leachii, Dej. Spec. 5. 36 ; Icon. 4. 320. pl. 207.

Wings rudimentary. Head and thorax brassy green, slightly coppery, the former large, with a roughish fovea on each side enclosing an elevated space on the crown very smooth, shining and coppery; eyes large and prominent; mandibles and antennx reddish, three joints at the base of the latter together with the palpi testaceous. Thorax heart-shaped, in front broad from angle to angle, thence gradually rounded and narrowed towards the base, where it becomes much contracted, posterior angles small and acutely elevated, the extremities of the base being sloped towards them, disk convex, with an impressed central furrow, the surface on each side faintly reticulated and very minutely wrinkled throughout, the entire base depressed and somewhat rugose. Elytra elongate, sides parallel, apex obtuse, disk rather depressed, finely but distinctly striated, the striæ entire and very obscurely punctured, the third interstice with four deeper impressions, yellowish testaceous at the base and on the margins, with an obscure metallic fuscous cloud behind extending more or less upwards; underside brassy black, legs pale testaceous. Length $1_{4}^{\frac{3}{4}}$ line.

This species is recognized by its elongate and parallel form, its short moniliform antennæ and prominent mandibles. It is a local species, but occurs in great profusion near Liverpool and on the sands by the Chesil beach in the Isle of Portland when the tide is out. It is likewise found on the shores of the Firth of Forth sparingly, and in abundance on the shores of the Clyde at Kilpatrick, as well as on the eastern coast of Ireland.

\section{(TAchys, Ziegler.)}

2. B. scutellare : capite thoraceque brunneo-nigris, hoc subquadrato, posticè subangustato, angulis posticis oblusiusculis; elytris oblongis, subparallelis, obsoletè striatis, striis exterris 
deletis, testaceo-lividis maculâ suturali communi fuscâ ; antennis basi pedibusque testaceis.

Trechus scutellaris, Germ. Archiv, 2. f. 1.11 (1829).

Tachys scutellaris, Steph. Mand. 2.5 (1829), et Manual, p. 52.

Bembidium scutellare, Dej. Spec. 5. 39; Icon. 4. 324. pl. 207. -Jacq.-Duv. Ann. Soc. Ent. 10. 209.

Head and thorax black or brownish black, antennæ pitchy with the base testaceous. Thorax subquadrate, sides a little rounded below the anterior angles, narrowed behind the middle and obliquely sloped towards the posterior angles which are obtuse but rather elevated, disk convex, smooth and shining, the dorsal furrow terminating in front in a triangular impressed space, the base depressed and with a fovea near each angle. Elytra rather straight in front, with the humeral angles obtuse but not narrowed, sides almost parallel, disk depressed, livid testaceous, with the scutellum and a triangular patch at the base of the suture fuscous, the rest of the surface being sometimes more or less clouded, generally with the lateral margins and a patch behind (in rarer examples entirely) fuscous, the disk is likewise rudimentally striated and very obsoletely punctulated on some of the halfeffaced fragments of striæ near the suture, three of which are frequently more evident, each elytron has also an impression about the middle; legs testaceous, femora dusky. Length $1 \frac{1}{8}$ line.

Abundant in the salt marshes at Lymington and at Christ. church, Hants.

3. B. bistriatum : piceum, interdùm flavescens; thorace subquadrato, posticè subangustato, angulis posticis subrectis; elytris oblongo-ovatis, dorso bistriatis, interstitio quarto puncto impressis; antennarum basi pedibusque testaceis.

Elaphrus bistriatus, Dufts. Faun. 2. 205.

Bembidium bistriatum, Sturm, D. F. 6. 152. pl. 160.-Dej. Spec. 5. 42 ; Icon. 4. 327. pl. 207.--Heer, Faun. Helv. 123. -Jacq.-Duv. Ann. Soc. Ent. 10. 205.

Cillenum minimum, Curtis, Ent. 200. note.

Tachys minutissimus, Steph. Mand. 2. 7, et Manual, p. 53.

T. maritimus, Steph. Manual, p. 52.

Pitchy brown, sometimes paler. Head with the usual strix between the eyes, which are black, mouth, base of the palpi and of the antennæ testaceous. Thorax subquadrate, narrower than the elytra, somewhat obliquely contracted towards the hinder angles, which are elevated but a little obtuse, base with two fover. Elytra oblong-ovate, disk with two distinct striæ next the suture, 
which are a little waved as they approach the extremity and exterior to these with the vestiges of other abbreviated or broken strix, the fourth of which has an impression in front, the sides and apex smooth; legs testaceous. Length $\frac{3}{4}$ line.

Scarce, but found occasionally on the coast of South Wales; at Ryde, and on a broken sandy undercliff between Luccombe and Shanklin, Isle of Wight.

4. B. obtusum : capite thoraceque nigro-piceis, hoc transverso, lateribus rotundato, angulis posticis obtusis; elytris oblongo-ovatis, obscurè viridi-cyaneis, punctato-striațis, striis externis obsoletis ; antennarum basi tibiis tarsisque testaceis, femoribus brunneis.

Sturm, D. F. 6. 165. pl. 161.-Dej. Spec. 5. 177; Icon. 4.443. pl. 222.-Heer, Faun. Helv. 136.-Jacq.-Duv. Ann. Soc. Ent. 10.182.

Tachys obtusus, Steph. Mand. 2. 6, et Manual, p. 52.

T. immunis, pusillus et gracilis, Steph. Mand. 2. 6, et Manual, p. 52.

Head and thorax pitchy black, sometimes obscurely brassy, base of the antennæ testaceous. Thorax transverse, broad, sides dilated and rounded, scarcely narrowed behind, but with the base almost as wide as the anterior margin, posterior angles obtuse but elevated, disk convex, very smooth and shining, dorsal furrow slender, base narrowly depressed and furnished with two deep foveæ close to the hinder margin. Elytra oblong-ovate, broader than the thorax, convex, punctate-striated, one or two striæ nearest the suture carried to the apex, the others abbreviated before the apex, which exterior to these is smooth, the lateral striæ likewise very obsolete, the third interstice has two impressions, the surface is entirely pitchy black, sometimes with an obscure greenish or bluish tinge and not unfrequently more or less pitchy rust-colour, perhaps the result of a less degree of maturity; legs red with the femora generally pitchy. Length $\mathrm{J} \frac{1}{4}$ line.

Tachys immunis, pusillus and gracilis, Steph., belong to this species ; the latter is a smaller example. It is generally distributed.

\section{(Ocys, Kirby.) ,}

5. B. 5-striatum : capite thoraceque nigro-piceis, hoc transverso, angulis posticis obtusis; elytris oblongo-ovatis, obscurè viridi-cyaneis, punctato-striatis, striis externis obsoletis; antennis pedibusque testaceis. 
Gyll. Ins. Suec. 2.34 (1810) et 4. 413.-Erichson, Käfer, 131. -Jacq.-Duv. Ann. Soc. Ent. 10. 185.

Elaphrus pumilio, Dufts. Faun. 2. 214 (1812).

Bembidium pumilio, Sturm, D. F. 6. 148. pl. 159.-Dej. Spec. 5. 48 ; Icon. 4. 330. pl. 208.-Heer, Faun. Helv. 124.

Ocys currens, Steph. Mand. 2. 10, et Manual, p. 53.

Head and thorax pitchy black, obscurely bronzed, the former channeled on each side; antennæ and palpi reddish testaceous, penultimate joint of the latter dusky. Thorax transverse, sides rounded, lateral margins elevated, especially behind, posterior angles not quite rectangular but a little obtuse, dorsal furrow entire, base narrowly depressed, with two large foveæ. Elytra oblong-ovate, rounded at the shoulders, widest behind the middle, disk punctate-striated, the two striæ nearest the suture entire, then three more abbreviated, the rest rudimentary or nearly obliterated, apex and sides smooth, the third interstice with an impression behind, the entire surface pitchy black, sometimes rusty, with an obscure greenish or cyaneous reflection; underside ferruginous, legs reddish testaceous. Length 2 lines.

Not common : found chiefly in sandy localities ; Isle of Wight ; Hastings; Ockham Park near Ripley; Battersea fields; midland and eastern counties; Maplethorpe, Lincolnshire; Castle Eden Dene; near Edinburgh, Fife and Dollar, \&c. ; rarely in Ireland.

6. B. rufescens : ferrugineum; thorace transverso lateribus latè marginato, angulis posticis acutis; elytris ovatis, subcyaneomicantibus, punctato-striatis, striis externis obsoletis ; antennis pedibusque testaceis.

Tachis rufescens, Guérin, Note Topog. 123 (1823).

Bembidium rufescens, Dej. Spec. 5. 47 ; Icon. 4.329. pl. 208.-

Heer, Faun. Helv. 123.-Jaca.-Duv. Ann. Soc. Ent. 10. 187.

Ocys melanocephalus, Steph. Mand. 2. 10, et Manual, p. 53.

O. tempestivus, Steph. Mand. 2. 11, et Manual, p. 54.

Rusty red. Head often more or less pitchy, with a rough channel on each side; palpi and antennæ testaceous. Thorax short, transverse, about as wide behind as in front, sides rounded and widest about the middle and broadly margined, hinder angles acute, the dorsal line strongly marked, the anterior impression which meets it fine, the posterior one forming a depression which carries a few minute punctures between the two large basal foveæ. Elytra ovate, rather clouded and with an iridescent tinge, punctate-striated, the three punctured striæ nearest the suture deepest, the sides and apex smooth, the third interstice with an impression, the eighth with a raised fold and a depression by the 
side of it at the extremity; underside and the legs pale. Length $2 \frac{1}{2}$ lines.

Local, but widely distributed and frequently abundant; rare in Ireland.

\section{(Philocthus, Stephens.)}

7. B. biguttatum : nigro-subaneum; thorace transverso, lateribus rotundato, basi pone angulos emarginato, angulis posticis subrotundatis ; elytris oblongo-ovatis, disco fortitèr punctato-striatis, maculâ apicali antennarum basi pedibusque rufo-testaceis.

Carabus biguttatus, Fab. Mant. 1. 205 (1787).-Fab. S. El. 1. 208.

Bembidium biguttatum, Gyll. Ins. Suec. 2. 28.-Dej. Spec. 5 . 180 ; Icon. 4. 446. pl. 222.-Heer, Faun. Helv. 137.-Jacq.Duv. Ann. Soc. Ent. 10. 174.

Philocthus biguttatus, Steph. Mand. 2. 8, et Manual, p. 53.

P. fuscipes, Steph. Mand. 2. 8, et Manual, p. 53.

Var. $\beta$. viridi-æneum, elytrorum macula apicali antennarum basi pedibusque testaceis.

Bembidium biguttatum, Sturm, D. F. 6.162. pl. 161.-Erichson, Käfer, 131.

B. vulneratum, Dej. Spec. 5. 182 ; Icon. 4. 448. pl. 222.

Philocthus subfenestratus, Steph. Mand. 2. 8, et Manual, p. 53.

Above brassy black, sometimes greenish black, shining; antennæ pitchy black, with the base testaceous. Thorax transverse, rounded at the sides, not strictly speaking narrowed behind, but so rounded as to give it in a great measure that appearance, the posterior margin distinctly emarginate behind the angles which are somewhat rounded (Pl. II. f. 7), disk moderately convex, the dorsal furrow intersected by numerous fine transverse wrinkles and terminated before and behind in distinct impressions, the anterior one minutely strigose, the posterior one more distinct and somewhat rugose, the base also with an oblique deeply impressed fovea on each side. Elytra oblong-ovate, deeply striated near the suture, less deeply on the sides, all the striæ punctured, but the apex smooth, and with a round testaceous red spot near the outer margin more or less distinct; underside black, legs reddish testaceous. Length 2 lines.

This species may be distinguished from both aneum and guttula, by the more rotundate hinder part of the thorax, though some examples scarcely exceed the latter in size. It varies also in depth of colour; some examples have a more decided greenish tinge, and purplish varieties occasionally occur.

It is generally distributed and abundant. 
8. B. æneum : nigro-aneum; thorace breviore, transverso, basi pone angulos emarginato, angulis posticis obtusiusculis; elytris oblongo-ovatis, subtilitèr punctato-striatis; antennis pedibusque nigro-brunneis, femoribus obscurè aneis.

Germ. Spec. Nov. 1.28 (1824).-Jacq.-Duv. Ann. Soc. Ent. 10. 176.

Philocthus aneus, Steph. Mand. 2.7 (1829), et Manual. p. 53.

Bembidium biguttatum, var. A., Dej. Spec. 5. 180.

B. marinum, Schiödte, Dan. El. p. 333 .

This insect is of an obscure bronze colour and rather smaller than biguttatum. Head narrower and more convex, the frontal furrows less deeply impressed and the longitudinal space between them broader, smooth and shining, palpi and antennæ obscurely black, the basal joint of the latter sometimes pitchy, all the joints more robust than in biguttatum. Thorax decidedly shorter and more transverse, the lateral margins more reflexed and elevated at the posterior angles, which are consequently more evident, the base being emarginate below them, the dorsal furrow fine and met in front by a distinct depression, the disk being also faintly wrinkled, but not rugose at the base, which has on each side a narrow deep oblique fovea. Elytra oblong-ovate, not wide in front, as in the allied species, but somewhat narrowed at the angles which are more rounded off, the sides being likewise more rounded, the disk more finely punctate-striated and the punctured striæ less effaced towards the apex; the underside of the body and legs bronzed black. In some examples which I possess, possibly offering less degrees of maturity, the elytra are brownish black and there are indistinct traces of a pale spot behind, with the apex also slightly rusty, as well as the legs and basal joint of the antennæ, but these examples have still the same short thorax and finely punctate striæ of the elytra which distinguish the species.

This insect is found upon the coast; very abundantly in the north of England; on the shores of the Humber ; and near Bridport, Dorset, \&c. Also in Ireland.

9. B. guttula : nigro-subaneum; thorace brevi transverso, angulis posticis obtusis; elytris oblongo-ovatis, punctato-striatis, maculá apicali antennarum basi pedibusque rufo-testaceis.

Carabus guttula, Fab. Ent. S. 1. 166.-Fab. S. El. 1. 208. Bembidium guttula, Gyll. Ins. Suec. 2.27.-Dej. Spec. 5. 178;

Icon. 4. 444. pl. 222.-Jacq.-Duv. Ann. Soc. Ent. 10. 179. Philocthus guttula, Steph. Mand. 2. 9, et Manual, p. 53. 
Tachys binotatus, Steph. Mand. 2. 5, et Manual, p. 52 .

T. vittatus, Steph. Mand. 2. 5, et Manual, p. 52.

Var. $\beta$. suprì nigro-piceum, thorace lateribus rotundato, elytris immaculatis.

Philocthus homorrhous, Steph. Mand. 2. 9, et Manual, p. 53.

Bronzed black, antennæ dusky, with some of the joints at the base rusty red. Thorax transverse, short, with the sides less rounded, and wider behind than in biguttatum, the base subemarginate behind the angles, which are obtuse and more evident (PI. II. f. 8), the dorsal furrow slight, the transverse impressions distinctly marked, the basal foveæ large and deep. Elytra oblong-ovate, strongly punctate-striated on the disk, sides and apex smooth, the third interstice with the usual impressions, the exterior margin with a round testaceous spot before the apex; underside black, legs reddish testaceous. Length $1 \frac{1}{2}$ line.

Tachys binotatus and vittatus, Steph., are perfectly identical with this species, of which Philocthus hamorrhous, Steph., is a permanent variety.

Very common.

\section{(Peryphus, Megerle.)}

10. B. femoratum : nigro-aneum, subvirescens; thorace subcordato, basi obsoletè punctulato, utrinque foveolato; elytris oblongo-ovatis, punctato-striatis, striis externis obsoletis, maculis duabus magnis antennarum basi pedibusque testaceis, femoribus obscuris.

Sturm, D. F. 6. 117. pl. 155.-Dej. Spec. 5. 116 ; Icon. 4. 383. pl. 214.-Erichson, Käfer, 130.-Heer, Faun. Helv. 129.Jacq.-Duv. Ann. Soc. Ent. 10. 131.

Peryphus femoratus, Steph. Mand. 2. 12, et Manual, p. 54.

$P$. maritimus, Steph. Mand. 5. 385, et Manual, p. 54.

Head and thorax brassy brown, or brassy black, more rarely with a greenish tinge; palpi and antennæ obscure, two joints at the base of the latter testaceous red. Thorax subcordate, sides moderately rounded below the anterior angles, more narrowed behind than in either of the two following species, posterior angles nearly rectangular, disk convex, very glossy, having a slender dorsal furrow much wrinkled transversely and met by the usual impression in front which is finely marked, the base however with a considerable depression and faintly rugose or occasionally subpunctate between the basal fover which are deeply impressed. Elytra oblong-ovate, with the sides very slightly curved, so as to appear at first view somewhat parallel, moderately but distinctly punctate-striated on the disk, more slightly so on the sides, the 
seventh stria being very indistinct, more frequently quite obsolete and the apex entirely smooth, the colour is obscure brassy black or brassy brown, with an oblong testaceous patch on each shoulder and a smaller roundish or oblique one (sometimes connected therewith externally) before the apex; legs testaceous, femora pitchy at their base. Length $2 \frac{1}{4}$ lines.

This species is distinguishable from the three following by its narrower, more elongate and more convex form. The thorax especially is narrower, less dilated at the sides before the middle, which gives it that narrower appearance; the colour also is usually brassy black, whereas in concinnum and littorale the brassy green predominates, which is only seen in occasional examples of femoratum so distinctly. The elytra are more elongate and the sides more parallel, partaking less of the ovate form than in the next species, being also more finely punctate-striated and having the testaceous spots larger and clearer.

$P$. maritimus of the Stephensian collection is represented by examples of this species mixed up with others of littorale. I have examined the single example of $P$. maritimus in the late Mr. Rudd's collection (now in the Museum of the York Philosophical Institution), and find that it is a somewhat aberrant individual of the present species with the thorax rather greener; I therefore give maritimus as synonymous with $B$. femoratum. All the examples in the Stephensian cabinet which stand under the name $P$. concinnus are likewise perfectly identical with this insect; but the descriptions given by the late Mr. Stephens of $P$. concinnus, Kirby, as well as the examples standing under that name in the Kirbian collection, correspond with the insect recorded in this work as B. concinnum.

Commonly distributed.

11. B. Bruxellense : viridi-aneum; thorace brevi subcordato, basi distinctè punctulato; elytris oblongo-ovatis, fortitèr punctato-striatis, striis externis obsoletis, maculis duabus magnis antennarum basi pedibusque rufo-testaceis, femoribus obscuris.

Wesmael, Bull. Acad. p. 47 (1835).-Jacq.-Duv. Ann. Soc. Ent. 10. 130 .

B. femoratum, Gyll. Ins. Suec. 4. 406.

B. obscurum, Redt. Faun. Aust. 111.

Rather larger and considerably darker than the preceding species. Head broader, more coarsely foveated; antennæ brownish black, the basal joint alone entirely and merely the base of some of the following joints red. Thorax usually greener bronze, 
evidently broader, less convex, posterior angles more acute, the dorsal furrow and transverse impressions more strongly marked, and the depression of the base running into the basal foveæ, which are much larger, the space between them being not merely subpunctate, but impressed with a distinct punctuation. Elytra broader, the sides less parallel, the punctured striæ more strongly impressed, the testaceous red spots being also smaller and more obscure; legs red, femora dusky. Length $2 \frac{1}{2}$ lines.

Not uncommon at Whittlesea Mere; it had also been taken by Mr. Curtis many years ago, and stands in his cabinet under the MS. name palustris. Mr. Haliday includes this insect among the species captured by him in Ireland; and it is stated by Mr. Murray to be not rare in Scotland.

12. B. concinnum : viridi-ceneum; thorace brevi subcordato, basi obscurè rugoso ; elytris oblongis, subparallelis, fortitèr punctato-striatis, striis externis obsoletis, pallidè testaceis, maculâ suturali latâ in medio dilatatâ fusco-æneâ; antennis palpis pedibusque pallidè testaceis.

Peryphus concinnus (Kirby), Steph. Mand. 2. 12 et 5. 385, et Manual, p. 54.

Bembidium concinnum, Putz. Stett. Ent. p. 138.-Jacq.-Dur. Ann. Soc. Ent. 10. 139.

This insect is broader and more depressed than either of the two preceding and more parallel than Bruxellense. Head and thorax distinctly green, somewhat brassy; palpi and antennæ entirely pale testaceous. Thorax shorter, wider and less convex than in femoratum, the disk very much wrinkled transversely, the base somewhat rugose and subpunctate, the posterior angles slightly acute. Elytra (Pl. II. f. 13) oblong, sides rather parallel, disk deeply punctate-striated, the punctures very evident, the margins and apex smooth, pale testaceous, with a broad brassy brown longitudinal stripe down the suture, extending about as far as the outside of the third interstice, in width, expanding about the middle but not reaching so far as the outer margin, then contracting again as it approaches the apex, assuming altogether somewhat the appearance of a cross placed in the centre, but leaving the outer margins of the wing-cases always entirely pale testaceous; legs likewise pale testaceous. Length $2 \frac{1}{2}$ lines.

The individuals placed under this name in the Kirbian collection perfectly correspond with the species here described, with which also Stephens's descriptions correspond, though the supposed examples in his cabinet must be referred to femoratum. 
This species is found in salt marshes and estuaries, and on the banks of tidal rivers, as well as on the sea-shore, often in great abundance, and is widely distributed. Banks of the Derwent, Tyne and Tees; Barmouth; shores of the Thames at Richmond, \&c.; estuary of the Shannon at Limerick.

13. B. littorale: capite thoraceque viridi-aneis; thorace subcordato posticè punctulato; elytris oblongo-ovatis, dorso profundè punctato-striatis, nigro-ceneis, maculis duabus magnis antennarum basi palpis pedibusque rufo-testaceis.

Carabus littoralis, Oliv. Ent. 3.110(1795).-Marsham, Ent.452.

Peryphus littoralis, Steph. Mand. 2. 13, et Manual, p. 54.

B. rupestre, Gyll. Ins. Suec. 2. 19, et 4. App. 405.-Dej. Spec. 5. 111 ; Icon. 4. 377. pl. 213.-Heer, Faun. Helv. 129.

B. Andrea, Erichson, Käfer, 129.

B. ustulatum, Jacq.-Duv. Ann. Soc. Ent. 10. 143.

Peryphus tetraspilotus, Steph. Mand. 5. 385.

P. elegans, Steph. Mand. 5. 386, et Manual, p. 54.

Head and thorax brassy green; antennæ with three joints at the base testaceous, the remainder dusky, palpi testaceous with the penultimate joint occasionally somewhat pitchy. Thorax rounded at the sides almost to the base, then suddenly narrowed, but straight just before the angle so as to form with the base a right angle, moderately convex, dorsal furrow much wrinkled transversely, the base depressed and very distinctly punctured, the punctures extending a little way up the dorsal furrow, and with two large foveæ also punctured. Elytra oblong-ovate, obscure bronze with two large testaceous red patches on each, one upon the shoulder oblong and extending backwards nearly to the middle of the elytra, the other nearer the apex placed obliquely, the punctured striæ deeply impressed, but disappearing before the apex, the lateral ones less evident, the third interstice with the usual deep impressions; legs pale testaceous. Length $2 \frac{3}{4}$ lines.

$P$. tetraspilotus, Steph., belongs to this species; and $P$. elegans, Steph., appears to be a variety with pitchy black femora.

Very common.

14. B. fluviatile : viridi-aneum, convexum; thorace oblongocordato, posticè angustato; elytris elongato-ovatis, fortitèr punctato-striatis, nigro-aneis, maculis duabus magnis antennarum basi pedibusque testaceis. (Pl. III. f. B.)

Dej. Spec. 5. 113 ; Icon. 4. 379. pl. 213.-Heer, Faun. Helv. p. 129.-Jacq.-Duv. Ann. Soc. Ent. 10. 142.

This species is more elongate and convex than littorale. Head 
narrower, antennæ longer, smoother at the base, the penultimate joint of the palpi pitchy. Thorax very convex, narrow, oblongcordate, contracted behind, the dorsal furrow finer, the transverse impression in front only slightly strigose, the basal foveæ smaller and the space between them more delicately punctured. Elytra more elongate and convex, the punctured striæ more distinct on the sides, the exterior one being very evident, but the punctures disappear from all the strix sooner. as they approach the apex which is quite smooth, the testaceous spots are sinilar and the legs are also pale. Length 3 lines.

This insect is for the first time introduced into the British fauna from a fine series of specimens received from Mr. Hadfield, of Newark, who captured them on the banks of the Trent at Kelham.

15. B. lunatum : viridi-aneum; thorace brevi subcordato, basi punctulato; elytris oblongo-ovatis, profundè punctato-striatis, macula communi posticâ semilunatâ antennarum basi palpis pedibusque testaceis.

Elaphrus lunatus, Dufts. Faun. 2. 211.

Bembidium lunatum, Sturm, D. F. 6. 119.-Gyll. Ins. Suec. 4. App. 405.-Dej. Spec. 5. 108 ; Icon. 4. 375. pl. 213.Jacq.-Duv. Ann. Soc. Ent. 10. 148.

Peryphus lunatus, Steph. Mand. 2. 13.

P. ustus, Steph. Mand. 2. 14, et Manual, p. 54.

This species is considerably broader than littorale. Thorax wider and less convex, the sides more dilated and rounded, the base broader and less strongly punctured and the basal foveæ less rugged. Elytra about twice the width of the thorax at the base, depressed, profoundly punctate-striated, but the apex smooth, obscure greenish bronze, with a large obliquely-formed or semilunate testaceous spot common to both before the apex; legs also pale testaceous. Length 3 lines.

$P$. ustus, Steph., is a mature example of this species. The true C. ustus of Schönherr has not been taken in Britain.

Abundant on the banks of the Irthing and other places in the north of England; on the shores of the Humber; in Norfolk, \&c.

16. B. saxatile : obscurè viridi-aneum; thorace subcordato, posticè punctulato; elytris oblongis, subparallelis, fortiter punctatostriatis, striis omninò integris, maculis duabus magnis rufotestaceis; antennis basi pedibusque rufis. 
Gyll. Ins. Suec. 4. App. 406.-Dej. Spec. 5. 119; Icon. 4. 385. pl. 214.-Heer, Faun. Helv. 130.-Jacq.-Duv. Ann. Soc. Ent. 10. 125.

Peryphus saxatilis, Steph. Mand. 2. 12, et Manual, p. 54.

Above obscure greenish brass. Head and thorax sometimes a little coppery; base of the palpi and three joints at the base of the antennæ testaceous red, the remainder brownish black. Thorax subcordate, rather short, moderately rounded at the sides and narrowed behind, posterior angles right angles, the base depressed, and together with the two deep basal foveæ punctured, the dorsal furrow strongly impressed. Elytra oblong, rather narrowest in front, sides somewhat parallel, disk flatter than in the preceding species, strongly punctate-striated, the three or four strix nearest the suture as usual deeper than the rest, but the exterior ones also distinct and all of them carried to the apex, the third interstice with the usual evident impressions, two testaceous spots on each elytron, the one at the shoulder extending from the outer margin almost, if not quite, to the suture, the posterior one round and always rather the palest and most conspicuous; legs reddish testaceous, with the femora sometimes rather obscure. Length $2 \frac{1}{4}$ lines.

There is a permanent variety of this species, which I have found in profusion in the Isle of Wight and elsewhere in the south of England, presenting very constant characters. It is more depressed, never narrower in front, the sides therefore more parallel, and the colour is always much paler and the spots larger, that before the apex round and very conspicuous, and the anterior one occasionally expanding over the surface very considerably; and it is to be remarked that this paler variety is found only in the south, while the darker examples are confined to the more northern and eastern districts: abundant on the banks of the Tyne and Derwent, \&c., as well as in Ireland and Scotland, and occasionally near London: the pale variety all along our southern coasts.

17. B. testaceum : capite thoraceque viridi-aneis; thorace angustiore, subcordato, angulis posticis rectis, aut paululùm acutis; elytris oblongis, subparallelis, punctato-striatis, rufo-testaceis, suturâ distinctè fasciâque sinuatâ posticâ obsoletissimè virescentibus; antennis basi pedibusque rufotestaceis.

Elaphrus testaceus, Dufts. Faun. 2. 214.

Bembidium testaceum, Sturm, D. F. 6. 139. pl. 157.

B. obsoletum, Dej. Spec. 5.118; Icon. 4.384. pl. 214.-Heer, Faun. Helv. 130.--Redt. Faun. Aust. 111. 
B. tricolor, var. C., Jacq.-Duv. Ann. Soc. Ent. 10. 121.

Peryphus neglectus, Dawson, Ann. Nat. Hist. 3. 214 (1849).

Head and thorax dark metallic green and shining, palpi testaceous, with the penultimate joint slightly testaceous brown, the antennæ fuscous black, with the basal, second, third and basal half of the fourth joints pale testaceous, all the joints except the second rather long. Thorax subcordate, rather narrow, sides rounded, posterior angles right angles, sometimes more acute and prominent, disk convex, base depressed and punctured more or less between the basal foveæ, which are also punctate within. Elytra oblong, wide, twice as broad as the thorax at the base, humeral angles a little rounded, but not narrowed, sides parallel, disk deeply punctate-striated, the outer striæ obsolete and the apex smooth, the third interstice with the usual impressions; the whole surface suffused with reddish testaceous, except the suture which is obscure brassy green and a very indistinct fascia of the same colour behind, but under a powerful magnifying glass the surface appears more or less cloudy rufous with an obscure elongate testaceous patch at the shoulder extending downwards till it almost reaches another nearer the extremity, which slopes obliquely towards the suture and forms with the one on the other elytron a semilunar band; legs testaceous red. Length $2 \frac{1}{2}$ lines.

M. Jacquelin-Duval has united this insect with Carabus tricolor, Fab., without any doubt. No typical example, however, of that species has been found in Britain. Elaphrus testaceus, Dufts., presents the true characters of our insect; I have therefore retained the name.

It is found rarely in the north of England.

18. B. decorum: capite thoraceque viridi-aneis, hoc cordato, posticè angustato, basi obsoletè punctulato; elytris elongatis, subparallelis, punctato-striatis, viridi-cyaneis; antennis basi pedibusque rufis.

Carabus decorus, Panz. Faun. 73 (1789-1810).

Elaphrus decorus, Dufts. Faun. 2. 207 (1812).

Bembidium decorum, Sturm, D. F. 6. 122.-Dej. Spec. 5.135; Icon. 4. 401. pl. 216.-Heer, Faun. Helv. 132.-Jacq.-Duv. Ann. Soc. Ent. 9. 568.

Peryphus viridi-aneus, Steph. Mand. 2. 15, et Manual, p. 55.

$P$. albipes, Steph. Mand. 5. 386, et Manual, p. 55.

This species is more elongate than any of the other green species which follow it, and also flatter. Head and thorax brassy green, the former has the usual oblong impressions on each side rather rugged, and is distinctly punctured behind the eyes; the 
bases of the palpi and antennæ testaceous, the rest fuscous black. Thorax cordate, moderately rounded at the sides in front, narrowed behind, but straight immediately before the angles, which are right angles and slightly prominent, the disk very much but very finely wrinkled, the dorsal furrow strongly impressed, the anterior transverse impression faintly strigose, the basal foveæ slightly punctate, and the space between them obsoletely so. Elytra elongate, shoulders very little rourded, sides rather parallel, the disk depressed, brassy green with a bluish reflection, inclining more or less to reddish, strongly but not coarsely punctate-striated, the punctured striæ quite ceasing before the extremity and obsolete on the sides, the third interstice with two impressions as usual; the body beneath black, legs red. Length $2 \frac{3}{4}$ lines.

Peryphus viridi-aneus, Steph., is represented by examples of this species, and P.albipes, Steph., is an immature individual of the same: the true B. albipes, Sturm, has never been found in Britain. $P$. agilis, Spence, though represented in the Stephensian cabinet by specimens of decorum, is identical with $B$. monticulum as proved by the examples in the collection of the Entomological Society, as well as in that of Mr. Curtis.

This species is very abundant on the gravelly beaches of rivers in Wales and in the north of England, Scotland and Ireland, as well as in the London district.

19. B. Stomoides : viridi-aneum, valdè convexum; thorace oblongo cordato, posticè fortitèr coarctato punctatoque; elytris oblongo-ovatis, punctato-striatis, striis posticè evanescentibus, octavâ apice profundè impressâ; antennis pedibusque testaceis.

(PI. III. f. A.)

Dej. Spec. 5. 146; Icon.4. 413. pl.218.-Redt. Faun. Aust. 108. B. albipes, Heer, Faun. Helv. 133.

B. rufipes, var. A., Jacq.-Duv. Ann. Soc. Ent. 9. 553.

Above brassy green. Head with two rugose furrows, punctured within, antennæ and palpi entirely testaceous red, the upper joints of the former duller and darker rust-colour. Thorax oblong, heart-shaped, sides much and regularly rounded in front, considerably contracted behind, posterior angles right angles, very convex, the dorsal furrow much wrinkled transversely, terminated before and behind in a deeper impression, the base considerably depressed and strongly punctured between the two very deep punctured foveæ, which are placed close within the angles. Elytra oblong-ovate, shoulders very much 
rounded, sides also rounded and rather widest behind the middle, disk very convex, deeply punctate-striated, the punctured striæ becoming fainter as they approach the extremity, the apex being quite smooth, but the outer strix not effaced till behind the middle, and the eighth is continued nearly to the tip, before which it assumes the form of a deeply impressed groove, the third interstice has two impressions close to the third stria; in some examples there is an obscure blood-red spot on the wingcases near the suture behind; underside greenish bronze, apex of the abdomen sometimes testaceous; legs testaceous. Length $2 \frac{1}{2}$ lines.

M. Jacquelin-Duval considers this insect an extreme variety of Elaphrus rufipes, Ill., of which species no typical example has occurred in Britain, if indeed the latter be distinct from B. rufipes, Gyll., Dej. It is readily distinguished by its very convex form and its similarity to the insect from which its specific name is derived (Stomis pumicatus); it is now introduced for the first time into the British fauna, having been discovered by Mr. Bold, of Newcastle, on a sandy bank of the river between Lanercost Abbey and Naworth Castle, Cumberland, in the month of June 1848 , but it is apparently very scarce.

20. B. monticulum : viridi-aneum; thorace cordato, posticè vix punctulato ; elytris oblongo-ovatis, convexiusculis, punctato-striatis, striis externis obsoletis, viridi-cyaneis; antennis basi pedibusque testaceis.

Sturm, D.F. 6.135. pl.158.-Jacq.-Duv. Ann. Soc. Ent. 9.565. Peryphus monticulus, Steph. Mand. 5. 386, et Manual, p. 55. $P$. agilis, (Spence) Steph. Mand. 2. 15, et Manual, p. 55.

Bembidium fuscicorne, Dej. Spec. 5. 139; Icon. 4. 406. pl. 217. -Heer, Faun. Helv. 132.- Redt. Faun. Aust. 765.

Brassy green, palpi and antennæ brownish, with the base testaceous. Thorax rather small, cordate, sides very little rounded before the middle, narrowed behind, posterior angles rather acute, base depressed, sometimes finely strigose between the two fover, but not distinctly punctured and sometimes indeed nearly smooth, the dorsal furrow well impressed, the disk finely wrinkled and moderately convex. Elytra oblongovate, much broader than the thorax, sides moderately and regularly rounded, convex, deeply punctate-striated next the suture, more finely so externally and the outside stria obsolete, leaving the sides as well as the apex smooth, the colour is greenish black with a cyaneous reflection; the underside bronzed black; the legs pale testaceous. Length $2 \frac{1}{2}$ lines. 
This species is more local and less abundant than many of its allies, and from its habit of remaining concealed in crevices of banks and old stumps, apt to be overlooked. It is found in the north of England and in Scotland. "Banks of the Tyne and in the gravel of a rivulet in a dene above Winlaton Mill." Messrs. Hardy and Bold. It is also found in willow stumps near Burtonon-Trent; and in July 1852 I captured a fine series by the side of the Dee, at Llangollen, by digging them out of a clayey bank.

21. B. nitidulum : viride, subcneum, nitidum; thorace, brevi, subcordato, angulis posticis rectis; elytris oblongo-ovatis, fortitèr punctato-striatis ; antennis basi pedibusque testaceis, femoribus basi nigro-piceis.

Carabus nitidulus, Marsham, Ent. 454.

Peryphus nitidulus, Steph. Mand. 2. 14, et Manual, p. 55.

Bembidium nitidulum, Jacq.-Duv. Ann. Soc. Ent. 9. 559.

B. rufipes, Gyll. Ins. Suec. 2. 18.-Dej. Spec. 5. 141; Icon. 4. 408. pl.217.-Erichson, Käfer, 130.-Redt. Faun. Aust. 107.

Above shining metallic green, sometimes bluish. Head (Pl. II. f. 15) short and triangular, narrowed in front so as to render the eyes rather prominent; base of the palpi and two or three joints at the base of the antennæ testaceous, the remainder, together with the penultimate joint of the palpi, pitchy brown. Thorax short, subcordate, much broader than in monticulum, sides moderately rounded in front and a little narrowed behind, but rather abruptly so, posterior angles right angles, the dorsal furrow transversely wrinkled and terminating before in an evident impression strongly marked, the base much depressed and rather coarsely punctured, the basal foveæ large and deep. Elytra oblong-ovate, convex, deeply punctate-striated, the striæ entire on the sides (but the punctuation finer) and carried nearly if not quite to the apex, before which however the punctures disappear, the third interstice with two impressions; underside brassy black, the apex of the elytra sometimes rusty red, legs testaceous, with the thighs more or less pitchy black at the base, sometimes wholly testaceous. Length $2 \frac{1}{2}$ lines.

Extremely abundant and generally distributed.

22. B. affine : viride, subaneum; capite oblongo, oculis haud prominulis; thorace subcordato, angulis posticis prominulis; elytris oblongo-ovatis, leviùs punctato-striatis, ante apicem rufescentibus; antennis basi pedibusque totis rufotestaceis. 
Peryphus affinis, (Rudd) Steph. Mand. 5. 386.

$P$. rufipes, Steph. Manual, p. 55.

Bembidium nitidulum, var. C., Jacq.-Duv. Ann. Soc. Ent. 9.560

Above green, very slightly brassy, shining, considerably larger than nitidulum. Head more oblong and flatter, broader in front, so that the eyes do not appear at all prominent (PI. II. f. 14), palpi and three joints at the base of the antennæ testaceous, the rest of the antennæ brownish and all the joints longer than in nitidulum. Thorax sensibly less short, the sides less dilated in front and less abruptly narrowed behind, the base very slightly or altogether obsoletely punctulated. Elytra broad, more rounded on the sides, strongly striated on the disk, but the punctuation finer and entirely effaced at the extremity, at some distance from which there is frequently an obscure red blotch common to both wing-cases and extending quite across them; legs entitely testaceous red. Length $2 \frac{3}{4}$ lines.

M. Jacquelin-Duval has considered this insect a variety of the preceding, but as I have never been able to unite them satisfactorily by intermediate links, I have retained it under the name affine, to which it is fully entitled, because the name rufipes, Ill., is applicable to a different species, whilst rufipes, Gyll., is identical with nitidulum. The examples of Peryphus affinis in the late Mr. Rudd's collection which I have examined, perfectly accord with the present species. They were captured by him near Marton, Yorkshire; and the insect is widely distributed though somewhat local, in gravel-pits near London, Woking, Isle of Wight, Northampton, North Wales, \&c.

23. B. tibiale : obscurè viridi-aneum, subcyaneum; thorace subquadrato, posticè subangustato, angulis posticis rectis; elytris oblongo-ovatis, punctato-striatis; antennarum basi tibiis tarsisque testaceis.

Elaphrus tibialis, Dufts. Faun. 2. 209.

Bembidium tibiale, Sturm, D. F. 6. 127. pl. 156.-Dej. Spec. 5. 134 ; Icon. 4. 399. pl. 216.-Heer, Faun. Helv. 131.

Peryphus tibialis, Steph. Mand. 2. 15 et 5. 387, et Manual, p. 56.

P. cnemerythrus, Steph. Manual, p. 55.

Bembidium fasciolatum, var. C., Jacq.-Duv. Ann. Soc. Ent. 10. 109.

Var. $\beta$. minus; suprà obscurè cyaneum, striis leviùs punctatis.

Peryphus atrocaruleus, Steph. Mand. 2. 17, et Manual, p. 56.

Obscure brassy green, with a bluish tinge, sometimes on the thorax only, sometimes very sparingly diffused over the elytra 
also, but the latter are usually dull brassy green, or obscurely bronzed. Head with a deep rough oblong fovea on each side, and a transverse impression and ridge in front, palpi obscure pitchy, antennæ fuscous black, with the basal joint alone red. Thorax somewhat quadrate, sides very little rounded from below the anterior angles to behind the middle, then straight, and forming, with the base, a right angle, which is very slightly elevated, the disk rather depressed, having a deep central furrow terminating in front in a small transverse impression, the base very much depressed and furnished with a very large fovea close to each angle, and extending more than half-way to the dorsal furrow, the space between the two being finely strigose longitudinally. Elytra oblong-ovate, broad, rather depressed, moderately striated, striæ distinctly punctured, interstices flat, the third stria with two deeper impressions, one about the middle, the other nearer the apex; underside bronzed, femora pitchy black, tibiæ and tarsi testaceous. Length $2 \frac{3}{4}$ lines.

The variety Peryphus atrocaruleus, Steph., is smaller and usually blue-black; its thorax is rather more narrowed behind, its elytra are less dilated and the striæ more slender and the punctuation finer; but none of these variations are to be relied upon as constant, as they more or less blend' into one another in a long series of individuals. M. Jacquelin-Duval, to whom I communicated some of my varieties, has connected atroccruleus, the variety above mentioned, with cyanescens, Wesmael, and by means of other links, with B. caruleum, Dejean, and has, moreover, united them all with Elaphrus fasciolatus, Dufts. (B. fasciolatum, Sturm) as the type, but as that particular form has never been found in Britain, I have retained the name tibiale for the present species.

This insect is extremely abundant on the gravelly beaches of rivers in mountainous districts, especially in the north of England and Wales, Scotland and Ireland.

24. B. prasinum : obscurè viridi-aneum; thorace brevi, subquadrato, angulis posticis prominulis; elytris oblongis, distinctè striatis, striis integris impunctatis; antennarum articulo primo plus minus rufo; pedibus nigris.

Elaphrus prasinus, Dufts. Faun. 2. 201.

Bembidium prasinum, Sturm, D. F. 6. 146.-Dej. Spec. 5. 129 ;

Icon. 4. 394. pl. 215.-Jacq.-Duv. Ann. Soc. Ent. 10. 104. B. olivaceum, Gyll. Ins. Suec. 4. 408.

Peryphus olivaceus, Steph. Mand. 2. 16, et Manual, p. 56.

P. Leachii, (Spence) Steph. Mand. 2. 16, et Manual, p. 55. 
Above obscure greenish bronze, depressed. Head with a short fovea on each side, terminated in front by a stria and transverse ridge; palpi and antennæ black, the basal joint of the latter sometimes entirely, at other times only underneath dull red. Thorax very short and broad, very slightly narrowed behind, so that the base is sensibly wider than in any of the preceding species, posterior angles prominent, the base and two wide shallow foveæ near the angles very much wrinkled so as to present the appearance of being finely rugose, the disk on each side the dorsal line being also finely strigose. Elytra broad, slightly widest behind, striated, the striæ entire on the sides and at the apex, the first and second, third and fourth and sometimes the fifth and sixth united at their extremity, but the fifth often more deeply impressed in the form of a curve carried round the ends of the third and fourth and almost united with the first and second, all the striæ are wholly impunctate, with the interstices flat, the third with two impressions; underside of the body bronzed black, legs obscure black. Length $2 \frac{1}{2}$ lines.

Immediately distinguishable from the preceding by its impunctate striæ and by the great width of the thorax. The insect described by Stephens as Fellmanni probably belongs to this species, as the description corresponds, but there are no examples in the Stephensian cabinet to represent it. P. Leachii and olivaceum also belong to this species, to which the name prasinum must be assigned in right of priority.

It appears to be a rare species, but is found occasionally in the north of England and in Scotland; Castle Eden Dene and the banks of the Derwent; Carlisle; Carfin; Loch Lomond. I have captured it also on the banks of the Dee near Llangollen, North Wales.

\section{(Notaphus, Megerle.)}

25. B. flammulatum : capite thoraceque obscurè viridi-æneis, hoc subcordato, angulis posticis prominulis ; elytris fuscoæneis testaceo-variegatis, fortitèr punctato-striatis ; antennarum basi abdominis apice pedibusque piceo-testaceis.

Ocydromus flammulatus, Clairv. Ent. Helv. 2. 20 (1806).

Bembidium flammulatum, Jacq.-Duv. Ann. Soc. Ent. 10. 163.

B. undulatum, Sturm, D. F. 6. 156. pl. 160.-Dej. Spec. 5.63; Icon. 4. 342. pl. 209.-Heer, Faun. Helv, 125.

Notaphus undulatus, Steph. Mand. 2. 17, et Manual, p. 56.

Head and thorax greenish or blackish brass, the former with an impressed stria on each side; antennæ brownish black, with 
the base more or less testaceous. Thorax subcordate, longer and more quadrate than in ustulatum (Pl. II. f. 9), the sides rounded and rather dilated about the middle, very gradually narrowed behind till a little before the angles, then straight, so as to form with the posterior margin right angles, with the apex a little prominent, the disk very much wrinkled, the dorsal furrow strongly impressed and the anterior impression which meets it well defined, base with a deep fovea on each side, the space between which is depressed and very much striated longitudinally. Elytra oblong-ovate, shoulders distinctly rounded, much wider than the thorax, sides only slightly rounded, a little narrowed at the apex, very strongly striated, especially near the suture in front, the striæ distinctly punctured till behind the middle when the punctures disappear and the strix become smooth and less deep from thence to the extremity, between the second and third strix are two deep impressions and a few distinct punctures on the outer margin near the shoulders, the colour is usually brassy brown, more or less dark, and there is always a testaceous zigzag or wavy band extending transversely from the outer margin to the suture at no great distance from the apex, and a very obscure or obsolete one before the middle, which, in immature examples, extends over the surface of the anterior portion of the wing-cases; the apex of the abdomen testaceous, legs pitchy testaceous, with a greenish metallic hue on the upper side of the femora. Length $2 \frac{1}{2}-2 \frac{3}{4}$ lines.

Extremely abundant on the banks of rivers, in damp woods and marshes throughout the kingdom.

26. B. ustulatum : obscurè viridi-cneum; thorace breviore, angulis posticis rectis vix prominulis; elytris testaceovariegatis, subtilitèr punctato-striatis ; antennis basi pedibusque piceo-testaceis.

Carabus ustulatus, Linn. F. S. 810.-Fab. Mant. 205.-Fab. S. El. 1. 208.-Payk. Mon. 86.

Bembidium ustulatum, Sturm, D. F. 6. 158.-Dej. Spec. 5. 64; Icon. 4. 343. pl. 209.-Heer, Faun. Helv. 125.

Notaphus ustulatus, Steph. Mand. 2. 18, et Manual, p. 56.

N. nebulosus, Steph. Mand. 2. 18, et Manual, p. 56.

N. bifasciatus et obliquus, Steph. Mand. 2. 19.

Carabus varius, Oliv. Ent. 3. 110. pl. 14.

Bembidium varium, Jacq.-Duv. Ann. Soc. Ent. 10. 159.

Smaller than flammulatum, obscure brassy greenish or bluish black. Head with a shallow impression on each side, antennæ rather slender, having two or three joints at the base testaceous. 
Thorax (Pl. II. f. 10) shorter, the width greater than the length, the sides much less rounded below the anterior angles and but slightly narrowed behind just before the base, the posterior angles less prominent and smaller, the dorsal furrow very slender, the basal fover smoother and the space between them smoother also. Elytra shorter, the shoulders squarer and not narrowed, having the angles only a little obtuse and prominent, sides straighter, apex obtuse, disk finely striated, the striæ punctured to behind the middle, then smooth, having two deeper impressions between the second and third strix, the interstices smoother and flatter than in flammulatum; the colour more obscure, with usually two very indistinct reddish testaceous bands, commencing at the outer margin and disappearing entirely before they reach the suture, in frequent examples almost entirely obliterated or interrupted by the darker striæ, appearing as merely irregular spots, whilst at the shoulders and at the apex there are occasion. ally also pale spots of irregular shape; in less frequent examples the whole surface is more testaceous variegated with dusky markings; underside black, with the apex of the abdomen usually concolorous; legs pitchy testaceous. Length $2 \frac{1}{4}$ lines.

In the Linnæan collection examples of this species (mixed up with others of $B$. flammulatum) stand under the name Carabus ustulatus, Linn.; Notaphus nebulosus, bifasciatus and obliquus of the Stephensian cabinet must likewise be referred to the same species.

It is extremely abundant in marshy places and on muddy deposits.

27. B. obliquum : obscurè nigro-æneum; thorace subquadrato; elytris testaceo-variegatis, subtilitèr punctato-striatis ; antennis pedibusque nigris. (Pl. II. f. E.)

Sturm, D. F. 6. 160. pl. 161.-Dej. Spec. 5. 68; Icon. 4. 347 . pl. 210.-Erichson, Käfer, 126.-Heer, Faun. Helv. 125.Jacq.-Duv. Ann. Soc. Ent. 10. 157.

B. ustulatum, Gyll. Ins. Suec. 2. 29 .

Considerably smaller than ustulatum; above bronzed, or obscure greenish black. Head small, smooth, depressed in front, and with the usual oblong impression on each side behind the eyes, antennæ black, with the underside of the basal joint and the base of the palpi rusty. Thorax subquadrate, short, sides rounded in front below the angles, very little narrowed behind, and with the base still rather wide, the lateral margins finely but distinctly reflexed, the posterior angles right angles, disk finely 
channeled and the base with a deep fovea on each side. Elytra broader than the thorax, not at all narrowed in front, but with the humeral angles only a little rounded and slightly prominent, sides subparallel, or little rounded till beyond the middle, when they slightly curve off towards the apex, finely punctate-striated, the punctures vanishing before the apex, the third interstice with the usual impressions, brownish black with two transverse testaceous curved bands, more distinct externally next the outer margin, disappearing towards the suture, near which are four spots of the same colour placed somewhat quadrately, the hinder pair more oblong in form, and sometimes these bands are entirely wanting and a patch of testaceous spots next the suture alone is visible, or it is otherwise varied, the apex of the wingcases is also very narrowly edged with testaceous; underside of the body and the legs black. Length 2 lines.

Apparently rare, or generally overlooked; the only indigenous example which has come under my notice was captured by Mr. Bold, at Gosforth.

28. B. rupestre: viridi-ceneum; thorace brevi, subquadrato, angulis posticis rectis; elytris oblongo-ovatis, testaceis viridi-ceneo variegatis, fortitèr punctato-striatis; antennis basi pedibusque piceo-ferrugineis.

Cicindela rupestris, Linn. S. N. 2. 658.

Elaphrus rupestris, Fab. Mant. 1. 188.-Fab. S. El. 1. 246.

Carabus ustulatus, var. $\delta$, Payk. Mon. 87.

C. varius $\beta$, Oliv. Ent. 3. 110 . pl. 14.

Bembidium varium, var. A, Jacq.-Duv. Ann. Soc. Ent. 10. 160. Notaphus fumigatus, Steph. Mand. 2. 20, et Manual, p. 56. Bembidium fumigatum, Dej. Spec. 5. 72; Icon. 4. 348. pl. 210.

About the size of B. fumigatum. Head and thorax brownish or greenish brass; base of the antennæ testaceous. Thorax shorter, subquadrate, very slightly narrowed behind, so that the base appears much broader than in fumigatum (Pl. II. f. 11). Elytra shorter, less dilated on the sides, more convex, more deeply punctate-striated, obscurely bronzed, and very much variegated with testaceous, which latter colour assumes the form of interrupted transverse bands, or the testaceous colour predominates and is speckled and varied with bronze; underside brassy black, legs red, femora sometimes dusky. Length 2 lines.

M. Jacquelin-Duval has united this insect with B. ustulatum under the name varium, Oliv.; Paykull in his Monograph likewise records it as a variety of that insect. It has long been a matter of dispute as to what insect Cicindela rupestris of Linnæus 
ought to be referred, that name having been successively applied to $B$. femoratum, articulatum and littorale, but rejected on the ground that Linnæus states the legs to be black. In the Linnæan collection we find a mutilated individual of the species before us (B. fumigatum, Dej.); and I have accordingly ventured to restore the name as originally asserted by Paykull (C. ustulatus var. $\delta$. $=C$.rupestris, L.). Linnæus probably described his insect from an example with unusually dark legs.

The species, which appears very distinct, is extremely rare in Britain. The only indigenous examples $I$ have seen are in the Stephensian cabinet and are stated to have been found at Swansea.

29. B. fumigatum : nigro-ceneum; thorace subcordato, posticè subangustato, angulis posticis rectis; elytris oblongoovatis, testaceo-variegatis, fortiter punctato-striatis ; antennis basi pedibusque rufo-testaceis.

Elaphrus fumigatus, Dufts. Faun. 2. 204 (1812).

Bembidium fumigatum, Jacq.-Duv. Ann. Soc. Ent. 10. 166.

Notaphus stictus, Steph. Mand. 2. 20, et Manual, p. 56.

Bembidium assimile, var., Erichson, Käfer, 167.

B. Dejeanii, Putz. Prem. Ent. 61.

About the size of the preceding species, but narrower in front. Head and thorax obscure greenish bronze, tip of mandibles and two joints at the base of the antennæ testaceous red, the rest of the antennæ and palpi obscure. Thorax (PI. II. f. 12) subcordate, sides more rounded and dilated about the middle, then contracted, but just before the angles sensibly straight, so as to form with the base a right angle, disk moderately convex, the dorsal and transverse lines well defined, the base with two foveæ. Elytra oblong-ovate, deeply punctate-striate on the disk, the sides and apex smooth, the first stria nearest the suture entire, the next rather abbreviated, all the others still more so, the colour varies from testaceous spotted or banded with fuscous or bronzed black, or the latter predominates and is more or less variegated with testaceous, very much after the manner of flammulatum; the underside is bronzed black, the legs are testaceous red. Length $1 \frac{3}{4}-2$ lines.

Abundant in marshy places, but rather local: Hammersmith marshes; the fens of Essex and Lincolnshire, \&c.

30. B. ephippium : capite thoraceque viridi-ceneis, nitidis ; thorace subcordato, posticè coarctato, angulis posticis rec- 
tis ; elytris oblongis, punctato-striatis, pallidè testaceis, maculá communi posticá fusco-brunneâ; antennis pedibusque pallidis.

Carabus ephippium, Marsham, Ent. 462.

Notaphus ephippium, Steph. Mand. 2. 20, et Manual, p. 57. Bembidium ephippium, Redt. Faun. Aust. 107.-Jacq.-Duv. Ann. Soc. Ent. 10. 156.

B. pallidipenne, Dej. Spec. 5. 74 ; Icon. 4. 350. pl. 210.

This little species has the head and thorax greenish black and very shining; palpi and antennæ testaceous, penultimate joint of the former pitchy. Thorax subcordate, sides rounded in front, contracted behind the middle, with the posterior angles right angles, but distinctly elevated, the dorsal line transversely wrinkled, the basal foveæ large. Elytra oblong, sides almost parallel, distinctly and regularly punctate-striated throughout, the third interstice with the usual impressions, the surface testaceous with a more or less obsolete or widely diffused dusky patch behind, extending entirely across, and sometimes a small darker one at the base of the suture; legs pale testaceous. Length $1 \frac{1}{2}$ lines.

Abundant in salt marshes: Lymington; Christchurch ; Whitstable; Isle of Sheppey; Great Yarmouth, \&c.

31. B. assimile: obscurè viridi-aneum; thorace subcordato, posticè parùm angustato utrinque foveolato, angulis posticis rectis; elytris oblongo-ovatis, fortitèr punctato-striatis, apice maculâ rotundatâ ante apicem antennarum basi pedibusque testaceis.

Gyll. Ins. Suec. 2. 26.-Dej. Spec. 5. 175; Icon. 4. 411.pl. 221. -Erichson, Käfer, 135.-Heer, Faun. Helv. 136.-Jacq.-Duv. Ann. Soc. Ent. 10. 168.

Lopha Doris, Steph. Mand. 2. 25, et Manual, p. 58. L. Spensii, Steph. Mand. 2. 25, et Manual, p. 58.

Notaphus castanopterus, Steph. Mand. 2.21, et Manual, p. 57.

Above greenish or bluish black. Head striated obliquely on each side and with a longitudinal ridge on the crown between the striæ, which approximate in front; antennæ brownish black, basal and next joint red. Thorax subcordate, the width across the middle greater than the length, rather contracted behind, posterior angles right angles, disk moderately convex, the dorsal furrow met before and behind by a shallow transverse impression, base with a deep fovea close to each angle. Elytra oblong-ovate, deeply punctate-striated, the punctured striæ deepest next the 
suture and vanishing before the apex, the third interstice with two impressions, near the outer margin behind is a testaceous spot, more or less distinct and large, the apex being likewise sometimes livid testaceous; body beneath black, legs testaceous red. Length $1 \frac{1}{2}$ line.

Notaphus castanopterus, Steph., is a pale and immature variety of this insect, from which Lopha Spensii and Doris of the Stephensian cabinet do not differ.

It is an abundant species in marshy places and is widely distributed: Whittlesea Mere and the fens of Cambridgeshire, Huntingdonshire and Lincolnshire, in profusion; and in the London district. It is included likewise among the Irish Bembidia.

32. B. Clarkii : nigro-piceum, interdùm obscurè viridi-ceneum; thorace latiore, subquadrato, posticè subangustato utrinque foveolato bistriatoque, angulis posticis rectis; elytris oblongo-ovatis, fortitèr punctato-striatis, maculâ obsoletâ ante apicem antennarum basi pedibusque rufis. (Pl. III. f. E.)

Lopha Clarkii, Dawson, Ann. Nat. Hist. 3. 215 (1849).

Bembidium Clarkii, Jacq.-Duv. Ann. Soc. Ent. 10. 170 (1851).

Above pitchy black, occasionally obscure greenish brass. Head with a deep slightly flexuous furrow on each side, somewhat approximating in front, enclosing a strongly elevated ridge on the crown; mandibles pitchy red, palpi and antennæ pitchy black, basal joint of the latter wholly and base of some of the following joints red. Thorax subquadrate, sides dilated and rounded before the middle, rather narrowed behind, but the base still wider than in the preceding species, posterior angles right angles or slightly prominent, disk convex, the dorsal furrow met in front by a semicircular impression, and behind also by a slightly rugose depression, the base with a large bistriated fovea on each side. Elytra oblong-ovate, rather broad, convex, deeply punctate-striated, the punctured strix abbreviated before the apex which is smooth, the strix nearest the suture very deep, the exterior ones much more slender, the third interstice with two impressions, near the outer margin behind is a more or less obsolete round red spot; underside black, legs entirely red. Length $1 \frac{2}{3}$ line.

In its general structure and in the deep striæ and punctuation of the elytra, this species is allied both to assimile and gilvipes, but it is a more robust insect, the thorax especially is larger and 
broader at the base, and the head is more deeply sulcated than either.

It is a local species, which I first discovered in the marshes at Herringstone, near Dorchester, in May 1848; and named it after my friend and companion, the Rev. Hamlet Clark. I found it still more plentifully in the same locality in 1852; and have taken it likewise on the seashore in Pegwell Bay, near Ramsgate.

\section{(LeJA, Meg.)}

33. B. lampros : aneum, nitidum; thorace lateribus anticè latè rotundato, posticè coarctato, profundè foveolato, angulis posticis rectis; elytris oblongo-ovatis, striis punctatis apice evanescentibus sex distinctis; antennis basi rufis, pedibus rufo-testaceis.

Carabus lampros, Herbst, Archiv, 164 (1781).

Bembidium lampros, Jacq.-Duv. Ann. Soc. Ent. 9. 503.

Carabus celer, Fab. Ent. S. 1. 167 (1792).-Fab. S. El. 1. 210.

Bembidium celere, Gyll. Ins. Suec. 2. 17.-Sturm, D. F. 6. 140. -Dej. Spec. 5. 157; Icon. 4.421.pl.219._Erichson, Käfer, 135.

Tachypus celer, Steph. Mand. 2. 26.

T. properans, Steph. Mand. 2. 26, et Manual, p. 58.

T. acutus, chalceus et orichalceus, Steph. Mand. 2.27, et Manual, p. 58.

Var. $\beta$. elytris striis punctatis apice evanescentibus 7 distinctis, pedibus totis rufescentibus.

B. velox, Erichson, Käfer, 134.-Heer, Faun. Helv. 134.

Lopha pulchella, Steph. Mand. 2. 23, et Manual, p. 57.

Brassy, shining. Head with two deep parallel impressions between the eyes; antennæ dull black, with the first and second joints at the base more or less red and always so beneath; palpi dull pitchy. Thorax cordate, truncate before and behind, sides dilated and rounded considerably in front, much contracted behind, posterior angles right angles, disk very smooth and convex on each side the dorsal furrow, base with a deep fovea near each angle punctured within, the space between them being also punctured. Elytra oblong-ovate, narrowed and rounded at the shoulders, sides gradually and regularly rounded, disk convex, having six punctured strix distinctly marked, which vanish before they reach the extremity, leaving the apex smooth, the sides being also smooth, except that the outer margin has some irregular impressions, and on the third interstice are two punctures; underside of the body black, legs red, tibiæ often paler testaceous. Length $1 \frac{1}{2}$ line. 
This species commonly has but six punctured striæ on each wing-case and usually rather coarsely impressed, but in rarer instances there are seven rows of punctures, in which case they are generally finer, and this variety forms B. velox of Erichson; it has usually a duller and darker appearance, and something of a bluish tinge. Lopha pulchella, Steph., belongs tofthis variety, which is of unfrequent occurrence in Britain. Tachypus properans, chalceus and orichalceus of the Stephensian cabinet are perfectly identical with the typical insect, which is found in profusion everywhere.

34. B. Schuppelii : nigro-subvirescens; thorace subcordato, angulis posticis rectis ; elytris ovatis, fortitèr punctato-striatis; antennarum basi pedibusque rufo-testaceis, femoribus rufo-piceis. (Pl. III. f. D.)

Dej. Spec. 5. Supp. 860 ; Icon. 4. 440. pl. 221.-Jacq.-Duv. Ann. Soc. Ent. 9. 519.

Obscure greenish or bluish black. Head with two oblique furrows approximating in front; antennæ pitchy black with two joints at the base red, palpi rusty red with the penultimate joint obscure. Thorax broader than in gilvipes, sides rounded from below the anterior angles to behind the middle, then contracted a little, but straight immediately before the angle, so as to form with the posterior margin a right angle, disk convex, the dor'sal furrow and anterior transverse impression well marked, the base narrowly depressed and with a broad fovea on each side, which becomes distinctly bifid above. Elytra more ovate than in any of the allied species, strongly punctate-striated, the striæ carried very nearly to the extremity, before which they become finer and the punctuation disappears, but the apex itself is smouth ; underside bluish black, legs red, with the femora at their base pitchy. Length $1 \frac{1}{4}$ line.

This species is allied to gilvipes, but the thorax is evidently broader and less narrowed behind and the elytra are shorter and more ovate. Two examples were taken first by Messrs. Bold and Murray on the banks of the Irthing, near Naworth Castle, Cumberland; and subsequently about a dozen more by Mr. Wailes in the same locality; it has been taken occasionally also near Edinburgh.

35. B. gilvipes : nigrum; thorace subcordato, posticè coarctato, angulis posticis rectis; elytris oblongo-ovatis, fortitèr 
punctato-striatis; antennarum basi pedibusque rufo-testaceis.

Sturm, D. F. 6. 149. pl. 159 (1825).-Jacq.-Duv. Ann. Soc. Ent. 9. 520.

B. Mannerheimii, Dej. Spec. 5. 167 ; Icon. 4. 432. pl. 229.

Lopha nigra, Steph. Mand. 2. 24 (1829), et Manual, p. 57.

Black or pitchy black. Head less convex than in the preceding species, with two oblong frontal impressions very slightly approximating in front; antennæ obscure black, the basal, second and sometimes the third joints red. Thorax subcordate, narrower, rounded on the sides and more contracted behind than in Schuppelii, the posterior angles right angles, disk convex, dorsal furrow fine and intersected by minute wavy wrinkles, base with two fover, the space between which is somewhat depressed and punctulated. Elytra oblong-ovate, about twice the width of the thorax, sides evenly rounded, very convex, strongly punctate-striated on the disk, the striæ becoming finer at the apex and the punctures themselves wanting, the third interstice with two small impressions; legs wholly red. Length $1 \frac{1}{4}$ line.

Dejean has quoted this species as Mannerheimii of Sahlberg, but as the descriptions given by that author to represent his insect by no means correspond with the characters of the one before us, the appellation given to it by Sturm is now generally adopted.

It is very abundant in marshy districts.

36. B. pusillum : nigrum, subcyaneum; sulcis frontalibus parallelis ; thorace brevi subcordato, lateribus valdè rotundato, posticè fortitèr coarctato; elytris oblongo-ovatis, fortitèr striato-punctatis; antennis pedibusque brunneonigris.

Gyll. Ins. Suec. 4.403.-Dej. Spec. 5.165; Icon. 4.430.pl. 220. -Erichson, Käfer, 136.-Heer, Faun. Helv. 135.-Jacq.-Duv. Ann. Soc. Ent. 9. 525.

Lopha pulicaria, Steph. Mand. 2. 24, et Manual, p. 58.

L. minima, Steph. Mand. 2. 24, et Manual, p. 58.

Above black or blue-black. Head with two parallel frontal furrows ; palpi and antennæ obscure, the basal joint of the latter in some examples reddish. Thorax short, subcordate, very much rounded on the sides and much narrowed behind, the lateral margins acutely reflexed, especially behind, posterior angles obliquely formed and a little elevated, convex, the dorsal furrow 
slender, very minutely wrinkled on each side, the base depressed and furnished with numerous minute punctures which give it a finely rugose appearance, the foveæ small, deep and punctured within. Elytra oblong-ovate, humeral angles rounded but not narrowed, sides very little rounded, disk moderately convex, strongly punctate-striated, the punctured striæ entire on the sides but effaced at the extremity, the third interstice with an impression rather before the middle very distinct and another less evident behind, in rarer instances there is an indistinct reddish spot behind near the outer margin and sometimes the apex itself is rusty red; underside of the body and the legs black, tibiæ a little brownish. Length $1 \frac{1}{4}$ line.

Lopha pulicaria and minima of the Stephensian cabinet are identical with this species. Stephens has given as one of the characters of the former insect, 'oblique frontal striæ,' but this was probably through inadvertency. Whether Lopha nana, Steph., is to be referred as a small variety to this species I cannot determine, as that name has no representative in the Stephensian cabinet.

\section{Common.}

\section{(Lopна, Megerle.)}

37. B. doris : aneo-nigrum, nitidum; sulcis frontalibus obliquis, profundè impressis; thorace cordato, posticè fortitèr coarctato, angulis posticis prominulis; elytris oblongoovatis, punctato-striatis, apice maculâque rotundatâ ante apicem rufis; antennis basi pedibusque rufo-testaceis.

Carabus doris, Panz. Faun. 38 (1789-1810).

Elaphrus doris, Ill. Käfer, 1. 232 (1798).

Bembidium doris, Gyll. Ins. Suec. 2. 24.-Sturm, D. F. 6. 170. -Dej. Spec. 5. 172; Icon. 4. 437.pl.221.-Erichson, Käfer, 137.-Heer, Faun. Helv. 136.-Jacq.-Duv. Ann. Soc. Ent. 9. 529.

Brassy black, sometimes greenish or bluish. Head broader than in the next species, with two oblique frontal furrows strongly marked, which approximate and unite in front (Pl. II. f. 17); palpi and antennæ obscure with their base red. Thorax cordate, very convex, sides rounded more in front and not so much in the middle as in the preceding species, lateral margins very fine and not reflexed, the posterior angles rather prominent, the dorsal furrow and the usual transverse impression in front slenderly marked, the base with two foveæ and a puncture on each side the termination of the dorsal line as in the next species. Elytra oblong-ovate, convex, strongly striated, the striæ distinctly punctured, the punctured striæ effaced at the apex and on the 
sides, the third interstice with two small impressions and the exterior margin with a round red spot at no great distance from the apex, which latter is sometimes pale and the red colour occasionally suffused over the whole extremity; underside black, legs testaceous red. Length $1 \frac{1}{2}$ line.

This species is very liable to be confounded with $B$. normannum, which however is a somewhat narrower insect and has the frontal furrows parallel, for which reason I have assigned Lopha pusilla and hamorrhoidalis, Steph., to that species, though Dr. Schaum in his notes referred them to this; all the examples however in the Stephensian cabinet (with one exception, which is placed on one side with the MS. name virescens) evidently=normannum. Nearly all the specimens in British collections which stand under the name doris will, I suspect, prove identical with normannum.

Found rarely in salt marshes.

38. B. normannum : obscurè viridi-aneum, nitidum; sulcis frontalibus parallelis; thorace cordato, posticè fortiter coarctato, angulis posticis rectis; elytris oblongo-ovatis, punctato-striatis, apice antennarum basi pedibusque rufotestaceis.

Dej. Spec. 5. 164 ; Ieon. 4. 429. pl. 220.-Heer, Faun. Helv. 135.-Jacq.-Duv. Ann. Soc. Ent. 9. 522.

Var. $\beta$. elytris oblongo-ovatis, maculâ posticâ rotundatâ apiceque rufo-testaceis.

Lopha pusilla et assimilis, Steph. Manual, p. 57.

L. hamorrhoidalis, Steph. Mand. 5. 387, et Manual, p. 58.

Above obscure greenish bronze. Head smaller than that of doris, with two parallel frontal furrows (Pl. II. f. 16), antennæ dusky, with the basal and sometimes the two next joints red. Thorax cordate, very convex, widest and rounded before the middle, considerably contracted behind, posterior angles right angles, base with an oblique deep fovea placed close within the angle, the space between them and the slender dorsal furrow with some faint punctuation. Elytra oblong-ovate, sides very slightly rounded, very convex, punctate-striated, but with the apex smooth, the third interstice with the usual impressions, near the outer margin at no great distance from the apex is a red spot, often obsolete, sometimes very widely diffused and of a greater or less depth of colour, and sometimes the apex itself alone is red; underside black, legs testaceous red, femora occasionally obscure. Length $1 \frac{1}{2}$ line.

The individuals standing under the names Lopha pusilla, 
assimilis and hamorrhoidalis in the Stephensian cabinet are (with one exception) perfectly identical with this species. Stephens appears to have transposed the species $L$. assimilis and doris (normannum) in his collection.

This insect is common in salt marshes, on the sides of ditches in marshy districts and on the banks of tidal rivers. Lymington Salterns; shores of the Thames below Gravesend; Whitstable and Herne Bay; Isle of Sheppey and Southend; eastern counties, \&c.

39. B. articulatum : capite thoraceque obscurè viridi-aneis; hoc oblongo-cordato, posticè fortiter coarctato, angulis posticis rectis;-elytris oblongo-ovatis, punctato-striatis, testaceis, fasciâ pone medium et alterâ ante apicem fuscobrunneis ; antennis basi pedibusque testaceis.

Carabus articulatus, Panz. Faun. 30.

Bembidium articulatum, Gyll. Ins. Suec. 2. 23.-Dej. Spec. 5 . 188 ; Icon. 4. 456. pl. 223.-Heer, Faun. Helv. 138.-Jacq.Duv. Ann. Soc. Ent. 9. 535.

Lopha pocila, Steph. Mand. 2. 21, et Manual, p. 57.

Head and thorax brassy green, or bluish, more or less obscure; elytra reddish testaceous, with a fuscous irregular band a little behind the middle, behind which is a pale testaceous patch near the margin, then another fuscous band just before the apex. Head large, with an oblique oblong impression on each side uniting in front; eyes large; antennæ with three joints at the base testaceous, the rest of the antennæ and the penultimate joint of the palpi obscure. Thorax oblong, heart-shaped, very convex, sides much rounded in front, much contracted behind, the lateral margins not reflexed, the posterior angles rectangular but the tip acute and elevated, the dorsal furrow and transverse stria very slender, the base with two foveæ and a row of distinct punctures between them. Elytra oblong-ovate, very convex, distinctly punctatestriated, with the apex smooth, on the third interstice before the middle is a very evident impression and a fine puncture also behind; underside black, legs pale. Length $1 \frac{1}{2}$ line.

Not uncommon in damp gravel and sand pits, humid places in woods, \&c. throughout the kingdom.

40. B. 4-guttatum: capite thoraceque viridi-aneis vel nigroaneis; hoc oblongo-cordato, posticè fortitèr coarctato, angulis posticis subrectis ; elytris oblongo-ovatis, basi punctato-striatis, nigris, maculis in singulo duabus albidis; pedibus pallidis. 
Carabus 4-guttatus, Fab. Mant. 1. 205.-Fab. S. El. 1. 207. Elaphrus 4-guttatus, Ill. Käfer, 1. 233.

Bembidium 4-guttatum, Gyll. Ins. Suec. 2. 21.-Dej. Spec. 5. 183 ; Icon. 4. 450. pl. 222.-Heer, Faun. Helv. 137.Jacq.-Duv. Ann. Soc. Ent. 9. 537.

Lopha 4-guttata, Steph. Mand. 2. 22.

Head and thorax brilliant brassy black, or sometimes with a greenish gloss, the former with two oblong rugose impressions parallel to each other; mouth, palpi and antennæ brownish, the bases of the two latter testaceous. Thorax oblong, heart-shaped, very convex, much narrowed behind, posterior angles not prominent, basal foveæ broad with a fine punctuation between them, the dorsal and anterior transverse lines slender. Elytra oblongovate, rather wide, punctate-striated at the base only, the third interstice with two and the outer margin just below the shoulder with several deeper impressions, disk moderately convex, brilliant shining brassy black, with two whitish testaceous spots on each, one angularly formed placed a little below the shoulder and another smaller and round one a little behind the middle near the outer margin, but neither of them touching it; underside bronzed black; legs pale, with the knees and edges of the femora dusky. Length $2 \frac{1}{4}$ lines.

Common.

41. B. callosum : subaneo-nigrum, nitidum; thorace oblongocordato, angulis posticis subrectis; elytris oblongo-ovatis, anticè leviùs punctato-striatis, maculis in singulo duabus pallidis, lateraliter junctis; antennis basi pedibusque pallidis. (Pl. III. f. C.)

Kust. Käfer, 9. 23 (1847).-Jacq.-Duv. Ann. Soc. Ent. 9.540 (1851).

B. laterale, Dej. Spec. 5. 185 ; Icon. 4. 452. pl. 222.-Heer, Faun. Helv. 137.

This species very nearly resembles 4-guttatum, but is rather smaller, narrower and more delicately formed; the principal characters which distinguish it from that species are stated as follows : the colour of a deeper black; the base of the first joint of the antennæ alone testaceous red; the elytra more finely striated and the punctuation more minute, the humeral spot continued, but more narrowly along the lateral margin till it unites with the lower one which is smaller and less round than the corresponding one in 4-guttatum; in other respects they do not differ. Length 2 lines.

This species was first named by Dejean laterale, but as that name had previously been applied to the insect which represents 
the subgenus Cillenus by Dr. Leach, it has become necessary to adopt the next in priority. The insect is now for the first time introduced into the British Fauna on the authority of a single example, which was captured by Mr. Steuart on Woking Common in the summer of 1851, and is now in my possession.

42. B. 4-maculatum : nigro-ceneum, nitidum; thorace subcordato, posticè coarctato, angulis posticis subacutis; elytris oblongo-ovatis, dorso punctato-striatis, maculis in singulo duabus pallidis; antennarum articulo 1, 2, 3 et 4 basi pedibusque testaceis.

Cincidela 4-maculata, Linn. S. N. 1. 658.

Elaphrus 4-maculatus, Ill. Käfer, 1. 232.

Bembidium 4-maculatum, Gyll. Ins. Suec. 2. 22.-Dej. Spec. 5. 187 ; Icon. 4. 454. pl. 223.-Heer, Faun. Helv. 138.-Jacq.Duv. Ann. Soc. Ent. 9. 542.

Lopha 4-maculata, Steph. Mand. 2. 22, et Manual, p. 57.

Head and thorax brassy black, with a faint greenish coppery tinge, the former with parallel striæ; antennæ and palpi obscure, four joints at the base of the former red and the base of the palpi testaceous. Thorax subcordate, the posterior angles very minutely dentate, or subacute, the sculpture as in 4-guttatum. Elytra oblong-ovate, lightly but distinctly punctate-striated almost to the apex, with two pale testaceous patches on each, the form and position of which are much the same as those in 4-guttatum; underside bronzed black; legs testaceous, femora sometimes dusky. Length $1 \frac{1}{2}$ line.

Common.

\section{(Bembidium $p r$.)}

43. B. bipunctatum : aneo-cupreum, nitidum; capite punctato; thorace subcordato, anticè posticèque punctato; elytris punctato-striatis, foveolis duabus in singulo impressis; antennis pedibusque aneo-nigris.

Carabus bipunctatus, Linn. F. S. 806.-Fab. S. El. 1. 209.

Bembidium bipunctatum, Gyll. Ins. Suec. 2. 16.-Dej. Spec. 5. 98 ; Icon. 4. 365. pl. 212.-Heer, Faun. Helv. 127.-Jacq.Duv. Ann. Soc. Ent. 9. 493.

Tachypus bipunctatus, Steph. Mand. 2. 28, et Manual, p. 59.

Above brownish coppery, or bronzed, very shining. Head sparingly punctured on the crown and with a thickly punctured oblong channel on each side; palpi and antennæ black, the latter rather short. Thorax subcordate, sides dilated and rounded below the anterior angles, narrowed behind, the posterior angles 
rather prominent, disk convex, the dorsal furrow intersected by numerous transverse wavy wrinkles and the entire limb punctured, but the punctures on the sides very minute and sparingly distributed, the base with a punctured fovea near each angle. Elytra considerably broader than the thorax, shoulders a little rounded, sides somewhat parallel, oblong, finely punctate-striated till beyond the middle, when the punctured striæ disappear, the third interstice with two deep impressions; underside of the body and legs dark bronze; sides of the thorax punctured. Length 2 lines.

Abundant on the gravelly beaches of rivers in the north of England, in Wales, Scotland and Ireland; as well as in the London district and in many other parts of the kingdom. My friend G. Guyon, Esq., has found it in plenty on the shores of the Thames near Richmond.

44. B. velox: plerumque aneum; capite thoraceque punctatis, hoc cordato, posticè coarctato; elytris punctato-striatis, striis integris, interstitio tertio punctis duobus impressis; antennis basi pedibusque rufis.

Carabus velox, Linn. F. S. $22 \cdot 2$.

Elaphrus striatus, Dufts. Faun. 2. 198.

Bembidium striatum, Sturm, D. F. 6. 186. pl. 163.-Dej. Spec. 5. 93 ; Icon. 4. 300. pl. 211.

Tachypus striatus, Steph. Mand. 2. 28, et Manual, p. 59.

Bembidium punctatulum, Drapiez, Ann. 7. 275 (1820).--Jacq.Duv. Ann. Soc. Ent. 9. 483.

Bembidium chlorophanum, Sturm, D. F. 6. 187. pl. 163.

Tachypus chlorophanus, Steph. Mand. 2. 28, et Manual, p. 59. Bembidium aerosum, Erichson, Käfer, 124.

Brownish brassy or occasionally blue-black, variable in colour. Head thickly punctured, with an oblong fovea on each side; antennæ longer than in the preceding species and more slender, brownish black with the basal joint red. Thorax cordate, much contracted behind, convex, punctured throughout, but most closely in front and at the base. Elytra oblong, broad, sides almost parallel, apex rounded, disk convex, deeply punctatestriated, the punctures very evident, and the striæ continued to the apex, before which however the third and fourth, as well as the fifth and sixth unite in pairs, the third interstice has two deeper impressions ; underside black, blue-black, or bronzed, with some punctuation on the thorax and breast; legs. testaceous red, tibiæ with a greenish or bluish metallic tinge. Length $2 \frac{1}{2}$ lines.

This insect is the Carabus velox of the Fauna Suecica, and I have accordingly restored the name. 
It is very abundant on the gravelly beaches of rivers in the north of England, in Scotland and Wales. "Durham; by the Ouseburn and Derwent in April and June." Mr. Bold. Coasts of Lancashire and Cumberland; Midgeley Moor; shores of the Thames at Richmond and Kew, \&c.

45. B. pallidipenne: capite thoraceque viridi-aneis; capite punctato; thorace subcordato, posticè coarctato punctatoque; elytris ovatis, punctato-striatis, pallidè testaceis, fasciâ transversâ dentatâ in medio retrorsùm productâ fuscoæneâ; antennis pedibusque testaceis.

Elaphrus pallidipennis, Ill. Mag. 1. 489.

Tachypus pallidipennis, Steph. Manual, p. 59.

Bembidium pallidipenne, Jacq.-Duv. Ann. Soc. Ent. 9. 487.

B. Andrea, Gyll. Ins. Suec. 2. 15.-Dej. Spec. 5. 96 ; Icon. 4. 363. pl. 212.

Tachypus Andrea, Steph. Mand. 2. 29.

Head and thorax metallic green, or coppery, the former closely punctured and with a small fovea on each side; antennæ short and stout and together with the mandibles and palpi entirely testaceous ; eyes black and prominent. Thorax subcordate, sides dilated and rounded below the anterior angles, narrowed behind, disk convex, the base depressed and thickly punctured, the basal fover very shallow, the lateral margins sometimes very finely and sparingly punctured, the dorsal line met in front by a transverse depression and intersected by numerous fine wrinkles. Elytra ovate, convex, testaceous yellow, scutellum greenish, a triangular space at the base of the suture together with a transverse dentate or deeply waved band a little behind the middle brownish bronze, disk punctate-striated about as far as the middle, the punctured strix effaced at the extremity, the third interstice with two more distinct small impressions; legs testaceous. Length 2 lines.

This insect is not uncommon on the sedgy brinks of little streams and rills that run into the sea on the coasts of Norfolk, Suffolk, Essex, Dorset and Devon, \&c., and is found in similar localities in the north of England, in Scotland and Ireland. From its habit of remaining concealed during the day at the roots of moist sedgy grass, it is very liable to be overlooked. I have found it on the edge of a little stream that runs down to the Smalimouth sands near Weymouth, by treading the wet herbage, which brings them out of their places of concealment; though several entomologists, myself among the number, had previously searched the sides of that little rill without detecting it; and I have procured it under similar circumstances near Barmouth on 
the Welsh coast. Lough Neagh and Killarney are among its Irish localities.

46. B. paludosum : aneo-cupreum; thorace subquadrato, angulis posticis obliquis acutiusculis; elytris oblongis, punctatostriatis, foveolis duabus oblongis argenteis in singulo impressis.

Elaphrus paludosus, Panz. Faun. 20.

Bembidium paludosum, Sturm, D. F. 6. 179.-Steph. Mand. 2. 30, et Manual, p. 59.-Dej. Spec. 5. 79; Icon. 4.354. pl. 211. -Erichson, Käfer, 125.-Heer, Faun. Helv. 126.-Jacq.-Duv. Ann. Soc. Ent. 9. 473.

Above purplish brass variegated with copper, extremely brilliant during life. Head flattish, slightly channeled on each side between the eyes; antennæ obscure with the base coppery. Thorax wider than the head, somewhat quadrate, the breadth being very little greater than the length, anterior margin truncate, with merely the angles minutely prominent, sides very little rounded in front and only slightly narrowed behind, posterior angles minute and acute, the base being obliquely sloped upwards towards them so as to render them slightly prominent, the dorsal furrow entire, transversely wrinkled, and intersected in front by a shallow curved impression and behind by another which extends along the base between the two basal foveæ; the latter are deeply impressed. Elytra oblong-ovate, broadest from below the humeral angles to behind the middle, thence gradually narrowed to the extremity, disk convex, deeply punctate-striated, the striæ entire, but the punctures effaced towards the apex, the first and second strix unite at the extremity, the third and fourth and also the fifth and sixth are rather shorter and unite in pairs, the third interstice is broader than the others and bears two oblong silvery shallow pits, one about the middle, the other further behind, each with a minute puncture within it, the fourth and fifth striæ are sinuated about the middle and occasionally some of the others also; in fine fresh examples (but especially during life) all the spaces between the suture and the fourth stria are shining purplish copper, whilst the fifth, sixth and seventh interstices have patches of the same brilliant colour, the rest of the elytra being of a shining greenish copper colour, but the surface more or less variegated in different individuals; the underside of the body and the legs are obscure greenish bronze, base of the thighs testaceous. Length $2 \frac{1}{2}$ lines.

Plentiful on the banks of the Tees; near Sheffield, and Carlisle ; "Mitford and the banks of the Till; banks of the Derwent near 
Winlaton mill and Gibside, in June." Mr. Bold. "In profusion on the banks of the Rye near Helmsley, Yorkshire, in the autumn." Rev. A. Mathews. It is found likewise in Wales; Scotland; and at Lough Neagh and Kerry in Ireland.

\section{(TACHypus, Megerle.)}

47. B. flavipes : cupreo-coneum, subtilitèr punctatum; oculis magnis valdè prominulis ; thorace cordato; elytris oblongis, viridi nebulosis; antennis basi pedibusque testaceis.

Cicindela flavipes, Linn. S. N. 1. 658.-Marsham, Ent. 394. Elaphrus flavipes, Fab. Mant. 1. 187.-Fab. S. El. 1. 246. Bembidium favipes, Gyll. Ins. Suec. 2. 12.-Steph. Mand. 2. 30, et Manual, p. 59.-Dej. Spec. 5.192; Icon. 4. 460. pl. 223. -Jacq.-Duv. Ann. Soc. Fint. 9. 464.

Above brownish or greenish copper or brass, finely punctulated throughout; eyes very prominent and large; palpi and four joints at the base of the antennæ testaceous, the rest obscure. Thorax small, cordate, sides rounded and widest about the middle, considerably contracted behind, moderately convex, the dorsal line abbreviated, the base very obsoletely foveated. Elytra oblong, broad, rather straight in front and with the sides nearly parallel, clothed with a fine griseous pubescence and otherwise variegated with purplish and ashy streaks towards the sides, and exhibiting sufficiently evident though very faint traces of strix on the disk; the latter has likewise two larger impressions; underside bluish or greenish bronze, legs pale testaceous. Length $1 \frac{1}{2}$ line.

B. impressum of the Stephensian collection is a somewhat larger example of this insect, which is widely distributed in marshy places, in damp woods, on the banks of streams, \&c. throughout the kingdom.

48. B. pallipes : cupreo-ceneum, subtilissimè punctulatum; oculis magnis prominulis; thorace oblongo-cordato; elytris oblongo-ovatis, viridi nebulosis; antennis basi pedibusque pallidè flavis.

Elaphrus pallipes, Dufts. Faun. 2. 197.

Bembidium pallipes, Sturm, D. F. 6. 111. pl. 154.-Gyll. Ins. Suec. 4. 400.-Steph. Mand. 2. 30, et Manual, p. 59.-Dej. Spec. 5. 191 ; Icon. 4. 459. pl. 223.-Jacq.-Duv. Ann. Soc. Ent. 9. 468.

Head and thorax coppery brass, shining, finely rugose, eyes large and prominent, antennæ brown, with the basal joint above 
and the tip of the second brassy green, the third, fourth, and sometimes the fifth, together with the palpi, testaceous. Thorax oblong, heart-shaped, sides regularly and moderately rounded till behind the middle, then contracted, posterior angles subrectangular, the base being slightly sloped towards them, the disk very convex, the dorsal line and basal foveæ slightly impressed. Elytra oblong-ovate, clothed sparingly with an irregular ashy pubescence most distinct on the sides, coppery brass, rather clouded on the disk, which offers some faint traces of striæ near the suture and has two deep impressions, the sides variegated with rich green or purplish streaks, the punctuation of the entire surface very minute, with the exception of a few deeper impressions on the outer margin near the shoulder and at the apex, and the two deep impressions on each elytron above alluded to; the underside of the body is bluish or greenish bronze; the legs pale testaceous. Length $2 \frac{1}{2}$ lines.

Rather a local species; but found at Swansea; Cromer and Aldborough; on the banks of the Till and elsewhere in the north of England. 


\section{N D E X.}

Abax, 99

striola, 99

ACrodon, 126

Actephilus, 152

pumilus, 152

vernalis, 152

ACUPALPUS, 163

cognatus, 163

collaris, 164

consputus, 157

dorsalis, 158

exiguus, 161

harpalinus, 164

luridus, 161

meridianus, 159

nigriceps, 160

placidus, 162

similis, 165

Adelosia, 102

picea, 102

\section{Aëpys, 170}

fulvescens, 171

marinus, 171

Robinii, 171

\section{AёTOPHORUS, 6}

imperialis, 6

Agonum, 84

affine, 93

afrum, 89

atratum, 89, 91

Austriacum, 86

bipunctatum, 82

consimile, 91

cupratum, 95

cursitor, 92

emarginatum, 89

fulgens, 87

fuliginosum, 90

fuscipenne, 90

gracile, 90,91

lave, 89

livens, 82 marginatum, 85

micans, 92

modestum, 86

mœstum, 89

nigrum, 89

parumpunctatum, 88

pelidnum, 92-94

piceum, 90

picipes, 92

plicicolle, 88

pullum, 90

pusillum, 90

4-punctatum, 90, 95

rotundatum, 96

scitulum, 91

6-punctatum, 85

Simpsoni, 90

striatum, 90

Thoreyi, 94

versutum, 89

viduum, 88

vivale, 80

\section{Amara 116}

acuminata, 118

cerata, 119

apricaria, 128

atra, 119

aulica, 130

bifrons, 126

brunnea, 126

communis, 121

consularis, 127

convexior, 120

convexiuscula, 130

cursor, 122

curta, 119, 121

discrepans, 126

erythropa, 123

eurynota, 119

familiaris, 122

fulva, 129

gemina, 123

infima, 123

ingenua, 117, 125

lavis, 122

lata, 125

laticollis, 120

lucida, 122

nitida, 124 obsoleta, 117

obtusa, 120

oricalcica, 125

ovata, 117

patricia, 127

picea, 130

plebeia, 124

similata, 118

spinipes, 129

spreta, 119

strenua, 124

subanea, 125

tibialis, 123

tricuspidata, 124

trivialis, 117

Vectensis, 124

viridis, 123

vulgaris, 120

Zabroides, 127

Amblychus, 60

bipustulatus, 60

peltatus, 61

Amphyginus, 74

piceus, 74

Anchomenus, 81

albipes, 84

angusticollis, 82

atratus, 89

dorsalis, 83

fulgens, 87

fuliginosus, 90

gracilis, 91

junceus, 81

lævis, 87

livens, 82

lunatus, 68

marginatus, 84

memnonius, 82

micans, 92

modestus, 86

mœstus, 89

oblongus, 84

pallipes, 83

parumpunctatus, 88

pelidnus, 93

piceus, 92 
prasinus, 83

4-punctatus, 95

scitulus, 91

6-punctatus, 85

Thoreyi, 94

viduus, 88

\section{Anisodactylus, 131}

binotatus, 131

pœciloides, 131

virens, 131

\section{Argutor, 108}

anthracinus, 108

depressus, 112

diligens, 111

erythropus, 110

incequalis, 110

inquinatus, 109

interstinctus, 110

longicollis, 110

pullus, 11$]$.

rufomarginalus, 109

strenuus, 111

vernalis, 109

Attelabus, 5

melanurus, 5

Badister, 59

bipustulatus, 60

cephalotes, 60

humeralis, 61

lacertosus, 60

microcephalus, 60

peltatus, 61

sodalis, 62

suturalis, 60

unipustulatus, 60

\section{Bembidium, 174}

æneum, 180

aerosum, 208

affine, 190

albipes, 188

Andrea, 184-209

areolatum, 173

articulatum, 205

assimile, 198

biguttatum, 179

bipunctatum, 207

bistriatum, 176

Bruxellense, 182

callosum, 206

celere, 200

chlorophanum, 208

Clarkii, 199

concinnum, 183

decorum, 187

Dejeanii, 197 doris, 203

ephippium, 197

fasciolatum, 191

femoratum, 181

flammulatum, 193

flavipes, 211

fluviatile, 184

fumigatum, 197

fuscicorne, 189

gilvipes, 201

guttula, 180

lampros, 200

laterale, 175-206

Leachii, 175

littorale, 184

lunatum, 185

Mannerheimii, 202

marinum, 180

monticulum, 189

nitidulum, 190

normannum, 204

obliquum, 195

obscurum, 182

obsoletum, 186

obtusum, 177

olivaceum, 192

pallidipenne, 198-209

pallipes, 21]

paludosum, 210

prasinum, 192

pumilio, 178

punctatulum, 208

pusillum, 202

4-guttatum, 205

4-maculatum, 207.

5-striatum, 177

rufescens, 178

rufipes, 188-190

rupestre, 184-196

saxatile, 185

Schuppelii, 201

scutellare, 175

secale, 170

Stomoides, 188

striatum, 208

sulcatulum, 174

testaceum, 186

tibiale, 191

tricolor, 187

undulatum, 193

ustulatum, 194

varium, 194-196

velox, 208

velox, 200

vulneratum, 179

Blemus, 172

areolatus, 173

discus, 166

lapidosus, 168

longicornis, 167 micros, 166

pallidus, 168

paludosus, 167

rubens, 166

unifasciatus, 166

Blethisa, 53

multipunctata, 53

Brachinus, 19

crepitans, 20

explodens, 20

glabratus, 20

immaculicornis, 20

sclopeta, 20

Bradycellus, 162

cognatus, 163

collaris, 164

fulvus, 163

placidus, 162

similis, 165

Bradytus, 127

apricarius, 128

consularis, 128

crassus, 128

ferrugineus, 129

fulvus, 129

marginatus, 127

torridus, 128

\section{Broscus, 113}

cephalotes, 114

Buprestis, 116

bicolor, 83

piger, 116

\section{Calathus, 74}

apicalis, 77

Cisteloides, 75

crocopus, 76

flavipes, 76

fulvipes, 76

fuscus, 76

glabripennis, 78

melanocephalus, 77

microcephalus, 78

micropterus, 78

mollis, 77

nubigena, 79

ochropterus, 77

piceus, 74

rotundicollis, 74

rufangulus, 76

Callistus, 68

lunatus, 68 


\section{Calosoma, 41}

inquisitor, 42

Sycophanta, 42

\section{Carabus, 34}

acuminatus, 118

aneus, 140

Ethiops, 103

afer, 89

ayilis, 8

agrorum, 67

albipes, 84

angusticollis, 82

anthracinus, 107

anxius, 151

apricarius, 128

arenarius, 46

areolatus, 173

articulatus, 205

arvensis, 36

aterrimus, 104

atratus, 89

atricapillus, 6

aulicus, 130

auratus, 38

Austriacus, 86

axillaris, 22

azureus, 134

bicolor, 129

biguttatus, 179

binotatus, 131

bipunctatus, 207

bipustulatus, 60

borealis, 49

brevicollis, 48

cancellatus, 37

cassidens, 62

catenulatus, 35

celer, 200

cephalotes, 114

chalceus, 70

chlorocephalus, 19

chlorophanus, 134

Cisteloides, 75

clathratus, 38

collaris, 25, 164

complanatus, 46

consitus, 35

consputus, 157

consularis, 128

convexiusculus, 130

convexus, 40

cordatus, 137

crepitans, 20

crux major, 58

crux minor, 17

cuniculinus, 142

cupreus, 97

cyaneus, 34

cyanocephalus, 18 decorus, 187

depressius, 62-148

dimidiatus, 98

discoideus, 145

discus, 165

Doris, 203

dorsalis, 83, 158

dorsiger, 62

ephippium, 198

erythropus, 110

eurynotus, 118

exasperatus, 39

excavatus, 72

familiaris, 122

fasciatus, 11

fasciolatus, 24

femoralis, 13

fenestratus, 8

ferrugineus, 45

flavipes, 76

foraminulosus, 137

frigidus, 75

fuliginosus, 90

fulvipes, 146

fulvus, 129

fuscus, 76

yermanus, 132

gibbus, 116

glabratus, 40

granulatus, 37

guttula, 180

hamorrhoidalis, 18

Helopioides, 64

holosericeus, 64

honestus, 141

hortensis, 41

humeralis, 22

ignavus, 141

incequalis, 110

ingenuus, 125

inquisitor, 42

intricatus, 34

junceus, 82

lavis, 87

lampros, 200

lateralis, 47

lepidus, 98

leucophthalmus, 74

limbatus, 146

linearis, 8

littoralis, 47, 70, 184

lividus, 126

longicollis, 110

lucidus, 123

lunatus, 68

luteicornis, 143

madidus, 103

marginatus, 85

melampus, 148

melanarius, 106

melanocephalus, 77 meridianus, 159

micropterus, 78

micros, 166

minutus, 169

moestus, 89

mollis, 77

monilis, 35

multipunctatus, 53

nemoralis, 41

niger, 100

nigricornis, 66

nigrita, 107

nigropiceus, 174

nitens, 39

nitidulus, 190

nivalis, 48

oblongo-punctatus, 101

oblongus, 84

obscurus, 134

obsoletus, 118

ochropterus, 77

oricalcicus, 126

ovatus, 117

pallipes, 83

parumpunctatus, 88

patricius, 127

pelidnus, 92-93

peltatus, 61

Petiffi, 145

piceuis, 74-92

picimanus, 102

picipennis, 152

picipes, 92

pilicornis, 58

planus, 74

prasinus, 83

praustus, 45

pubescens, 138

pumicatus, 113

punctatulus, 135

puncticollis, 137

purpurascens, 39

4-guttatus, 206

4-maculatus, 9

4-notatus, 10

4-punctatus, 95

4-striatus, 169

rotundatus, 96

rotundicollis, 96

rubens, 167

rubripes, 147

rufangulus, 76

rufescens, 45

ruficollis, 112

ruficornis, 140

rufipes, 76

rufimanus, 149

sabulicola, 133

sabulosus, 47

Scalesii, 110

Sclopeta, 20 
secalis, 170

serripes, 150

6-punctatus, 85

sigma, 11

Silphoides, 63

spinibarbis, 43

spinilabris, 45

spinipes, 130

strenuus, 111

striola, 99

subcyaneus, 73

sulcicollis, 64

Sycophanta, 42

tardus, 149

tempestivus, 169

terricola, 73

Teutonus, 154

tibialis, 123

trivialis, 117

truncatellus, 13

turcicus, 17

ustulatus, 194-196

vaporariorum, 23, 154

varius, 194, 196

velox, 208

vernalis, 152

vespertinus, 155

vestitus, 67

vidures, 88

violaceus, 39

viridanus, 83

viridis, 123

vivalis, 80

vulgaris, 120

Ziegleri, 155

Celia, 125

Cephalotes, 114

vulgaris, 114

\section{Chlænius, 64}

agrorum, 67

fulgidus, 66

holosericeus, 65

melanocornis, 66

nigricornis, 66

sulcicollis, 64

vestitus, 67

xanthopus, 66

\section{Cicindela, 1}

aprica, 2

aquatica, 54

campestris, 3

flavipes, 211

germanica, 3

hybrida, 2

marina, 171

maritima, 3 riparia, 2 rupestris, 196

sylvatica, 1

sylvicola, 2

\section{Cillenum, 175}

laterale, 176

minimum, 24

Cillenus, 175

lateralis, 175

\section{Clivina, 24}

anea, 31

arenaria, 25

arctica, 115

collaris, 25

elongata, 27

fossor, 24

gibba, 32

metallica, 27

minima, 33

nigra, 30

nitida, 26

obscura, 29

polita, 27

thoracica, 30

Curtonotus, 129

convexiusculus, 130

piceus, 130

\section{Cychrus, 33}

rostratus, 33

\section{Cymindis, 21}

basalis, 23

homagrica, 22

humeralis, 21

punctata, 23

\section{Demetrias, 5}

atricapilla, 6

elongatula, 6

imperialis, 6

monostigma, 7

obscura, 6

unipunctata, 7

Diachromus, 132

germanus, 132

Dromius, 7

agilis, 8 angustatus, 13

bipennifer, 11

bipunctatus, 15

fasciatus, 12

femoralis, 13

fenestratus, 8

foveolus, 14

glabratus, 13

imperialis, 6

impunctatus, 15 .

linearis, 8

longiceps, 7

maurus, 13

melanocephalus, 12

meridionalis, 8

obscuroguttatus, 14

punctatellus, 14

quadrillum, 15

4 -maculatus, 9

4 -notatus, 10

4-signatus, 10

sigma, 11

spilotus, 15

truncatellus, 13

unipunctatus, 7

Drypta, 4

emarginata, 4

\section{Dyschirius, 25}

æneus, 31

cratus, 31

arenosus, 26, 30

cylindricus, 27

digitatus, 26

fulvipes, 26

gibbus, 33

globosus, 32

jejunus, 31

impunctipennis, 29

inermis, 26

minimus, 33

nitidus, 26

obscurus, 29

politus, 27

punctatus, 28

pusillus, 31

rufipes, 28

salinus, 28

thoracicus, 30

tristis, 31

\section{Elaphrus, 50}

aquaticus, 54

biguttatus, 56

bistriatus, 176

cupreus, 51

decorus, 187

Doris, 203 
flavipes, 211

fumigatus, 197

Lapponicus, 51

lunatus, 185

multipunctatus, 53

pallidipennis, 209

pallipes, 211

paludosus, 210

palustris, 54

prasinus, 192

pumilio, 178

4-guttatus, 206

4-maculatus, 207

riparius, 52

rupestris, 196

semipunctatus, 56

striatus, 208

testaceus, 186

tibialis, 191

uliginosus, $\mathbf{5 0}$

EpaphiUs, 170

secalis, 170

Feronia, 103

Ethiops, 103

anthracina, 107

aterrima, 104

cuprea, 97

depressa, 112

dimidiata, 98

gracilis, 108

lepida, 99

madida, 103

melanaria, 106

minor, 108

negligens, 110

nigra, 100

nigrita, 106

oblongo-punctata, 101

parumpunctata, 101

picimana, 102

pulla, 111

strenua, 110

striola, 99

vernalis, 109

Galerita, 24

fasciolata, 24

\section{Harpalus, 33}

acuminatus, 118, 146

æneus, 140

albipes, 84

angusticollis, 82

annulicornis, 141

anthracinus, 107

anxius, 151

apricarius, 128

aterrimus, 104 atricornis, 144

atroceruleus, 141

attenuatus, 143

aulicus, 129

azurescens, 147

azureus, 134, 147

bifrons, 126

binotatus, 131

brevicollis, 138

brunneus, 126

Caffer, 145

calceatus, 131

cephalotes, 114

chlorophanus, 135

chloropterus, 147

Cisteloides, 75

cognatus, 163

collaris, 164-165

communis, 121

confusus, 140

consentaneus, 143

coracinus, 151

cordatus, 136

cribellum, 138

cuniculinus, 142

cupreus, 148

cupreus, 97

depressus, 148

discoideus, 145

dorsalis, 158

emarginatus, 89

familiaris, 122

femoralis, 151

flaviventris, 151

foraminulosus, 137

fuliginosus, 149

fulvipes, 146

fulvipes, 76

fulvus, 129

fuscipalpis, 150

fuscus, 76

germanus, 132

gibbus, 116

gracilis, 91

Helopioides, 64

holosericeus, 65

honestus, 141

ignavus, 147

ingenuus, 125

lateralis, 146

latus, 128, 149

lentus, 147

lepidus, 98

leucophthalmus, 74

limbatus, 146

livens, 82

luridipennis, 69

luteicornis, 143

luteicornis, 151

maculicornis, 141

marginatus, 85 marginellus, 147

melampus, 148

melanarius, 106

melancholicus, 150

melanocephalus, 77

meridianus, 159

micropterus, 78

minor, 108

neglectus, 152

niger, 100

nigricornis, 144

nigripes, 151

nigroceruleus, 147

nitidus, 141

notatus, 141

oblongo-punctatus, 101

oblongus, 84

obscuricornis, 141

obscurus, 134

obsoletus, 139

parumpunctatus, 88

pelidnus, 93

perplexus, 145

Petiffi, 147 .

picipes, 92

picilabris, 143

picipennis, 153

piger, 151, 152

placidus, 162

plebeius, 124

prasinus, 83

pœeiloides, 131

pubescens, 138

pullus, 111

pumicatus, 113

punctatulus, 135

puncticollis, 137

puncíiger, 147

pygmaeus, 110

4-punctatus, 95

rotundatus, 96

rubripes, 147

ruficeps, 146

ruficornis, 139

rufimanus, 149

rifipalpis, 141

rufipes, 72

rufitarsis, 131

rupicola, 136

sabulicola, 133

semiviolaceus, 148

serripes, 150

servus, 143

6-punctatus, 85

similatus, 118

strenuus, 110

striola, 99

stygius, 150

subcordatus, 137

subcyancus, 73

subsinuatus, 147 
sulcicollis, 64

sulphuripes, 141

tardus, 149

tenebrosus, 150

thoracicus, 148

trivialis, 119

vaporariorum, 154

vernalis, 109, 152

vestitus, 67

viduus, 88

vulgaris, 120

Wetterhallii, 153

Wollastoni, 144

HeLobia, 47

athiops, 48

brevicollis, 47

Gyllenhalii, 48

lata, 48

Marshallana, 48

nivalis, 48

varicornis, 48

LAMPRIAS, 18

chlorocephalus, 18

cyanocephalus, 19

nigritarsis, 18

rufipes, 19

\section{Lebia, 16}

agilis, 8

atricapilla, 6

chlorocephala, 19

crux minor, 17

cyanocephala, 18

fasciata, 12

foveola, 14

glabrata, 13

hæmorrhoidalis, 18

homagrica, 22

humeralis, 21

linearis, 8

obscuroguttata, 14

punctatella, 14

quadrillum, 15

4-maculata, 9

4-notata, 10

truncatella, 13

turcica, 17

LEIOChITON, 115

arcticum, 115

Readii, 115

Leistus, 43

caruleus, 43

ferrugineus, 45

fulvibarbis, 44

indentatus, 44

Janus, 44 montanus, 44

nigricans, 43

rufescens, 45

spinibarbis, 43

spinilabris, 45

terminatus, 45

LEJA, 200

Iicinus, 62

depressus, 62

Silphoides, 63

Lronvchus, 15

quadrillum, 15

LOPHA, 203

assimilis, 204

Clarkii, 199

Doris, 198

homorrhoidalis, 204

minima, 202

nigra, 202

poecila, 205

pulchella, 200

pulicaria, 202

pusilla, 204

4-guttata, 206

4-maculata, 207

Spencii, 198

Loricera, 57

pilicornis, 58

Iymnæum, 173

areolatum, 173

depressum, 173

nigro-piceum, 174

Masoreus, 153

luxatus, 153

Wetterhallii, 153

Miscodera, 115

arctica, 115

Nebria, 46

arenaria, 46

borealis, 49

brevicollis, 47

complanata, 46

lateralis, 47

livida, 47

multipunctata, 53

nivalis, 48

sabulosa, 47

Notaphus, 193

bifasciatus, 194 castanopterus, 198

ephippium, 198

fumigatus, 196

nebulosus, 194

obliquus, 194

stictus, 197

undulatus, 193

ustulatus, 194

Notiophilus, 53

aquaticús, 54

biguttatus, 56

brevicollis, 54

brevis, 54

latior, 54

latus, 56

metallicus, 54

Newmanii, 54

nitidus, 56

palustris, 54

4-punctatus, 57

rufipes, 55

semipunctatus, 55

striatus, 56

substriatus, 56

tibialis, 54

OCyDromus, 193

fammulatus, 193

Ocys, 177

currens, 178

melanocephalus, 178

tempestivus, 178

Odacantha, 5

melanura, 5

ODONTONYx, 96

rotundicollis, 96

Olisthopus, 95

rotundatus, 95

Omaseus, 104

affinis, 106

anthracinus, 107

aterrimus, 104

Bulwerii, 105

lavigatus, 108

melanarius, 106

nigrita, 107

Orinomum, 105

rotundicollis, 108

rufifemoratus, 107

sulcatus, 106

tetricus, 108

Oödes, 63

Helopioides, 64 
INDEX.

Ophonus, 133

azureus, 134

cribellum, 138

foraminulosus, 137

germanus, 132

nitidulus, 135

obscurus, 134

obsoletus, 139

pubescens, 139

punctatissimus, 137

punctatulus, 135

puncticeps, 137

puncticollis, 138

sabulicola, 133

stictus, 134

subpunctatus, 138

Panagæus, 58

crux, 58

crux major, 58

4-pustulatus, 59

Patrobus, 71

alpinus, 72

excavatus, 72

rufipes, 72

septentrionis, 72

Pelophila, 49

borealis, 49

Percosia, 127

Peryphus, 181

affinis, 191

agilis, 189

albipes, 187

atrocceruleus, 191

cnemerythrus, 191

concinnus, 183

elegans, 184

femoratus, 181

Leachii, 192

littoralis, 184

lunatus, 185

maritimus, 181

monticulus, 189 .

neglectus, 187

nitidulus, 190

olivaceus, 192

rufipes, 191

saxalilis, 186

tetraspilotus, 184

tibialis, 191

ustus, 185

viridi-ceneus, 187

Prilocthus, 179

aneus, 180 biguttatus, 179

fuscipes, 179

guttula, 180

hamorrhous, 181

subfenestratus, 179

Platyderus, 112

ruficollis, 112

Platynus, 81

angusticollis, 82

Platysma, 101

aterrima, 104

crenata, 109

cuprea, 97

dimidiata, 98

lepida, 99

littoralis, 70

madida, 103

nigra, 100

oblongo-punctata, 101

picimana, 102

rufipes, 72

versicolor, 97

Pecilus, 97

cupreus, 97

dimidiatus, 97

lepidus, 98

versicolor, 97

Pogonus, 69

aruginosus, 70

Burrellii, 69

chalceus, 70

halophilus, 70

littoralis, 70

luridipennis, 69

Polystichus, 24

fasciolatus, 24

vittatus, 24

Pristonychus, 73

subcyaneus, 73

Terricola, 73

Pterostichus, 96

Ethiops, 103

anthracinus, 107

aterrimus, 104

brunnipes, 101

cupreus, 97

dimidiatus, 97

erythropus, 110

gracilis, 107

inæqualis, 110

lepidus, 98 macer, 102

madidus, 103

melanarius, 106

minor, 108

niger, 100

nigrita, 106

oblongo-punctatus, 101

Orinomus, 105

parumpunctatus, 100

picimanus, 102

ruficollis, 112

strenuus, 111

striola, 99

vernalis, 109

Scarites, 25

arenarius, 25

arcticus, 115

fossor, 25

gibbus, 32

globosus, 32

thoracicus, 30

Sphodrus, 73

leucophthalmus, 74

planus, 74

subcyaneus, 74

Stenolophus, 154

consputus, 157

derelictus, 159

dorsalis, 158

elegans, 156

exiguus, 161

flavicollis, 160

luridus, 160

meridianus, 159

Skrimshiranus, 155

'Teutonus, 154

vaporariorum, 154

vespertinus, 155

Steropus, 103

athiops, 103

arrogans, 103

cognatus, 104

concinnus, 104

madidus, 103

Stomis, 113

pumicatus, 113

Synuchus, 80

vivalis, 80

TACHIs, 178

rufescens, 178

TACHYPUS, 200

acutus, 200 
INDEX.

andrea, 209

bipunctatus, 207

celer, 200

chalceus, 200

chlorophanus, 208

orichalcicus, 200

pallidipennis, 209

properans, 200

striatus, 208

TACHYS, 175

binotatus, 181

gracilis, 177

immunis, 177

maritimus, 176

minutissimus, 176

obtusus, 177

pusillus, 177

scutellaris, 176

vittatus, 181

TAPHRIA, 80

vivalis, 80

Tarus, 21

angularis, 22

axillaris, 22

basalis, 23 coadnutus, 22

homagricus, 22

humeralis, 21

lavigatus, 22

macularis, 22

vaporariorum, 23

Tenebrio, 25

fossor, 25

rostratus, 33

Trechus, 165

aquaticus, 169

brunnipes, 164

cognatus, 163

collaris, 164

consputus, 157

discus, 165

dorsalis, 158

flavicollis, 160-161

fulvescens, 171

fulvus, 164

fuscipennis, 169

incilis, 168

lapidosus, 168

lævis, 169

laticollis, 153

littoralis, 167 longicornis, 167

meridianus, 159

micros, 166

minutus, 169

nitidus, 161

obtusus, 169

pallidus, 164

paludosus, 167

parvulus, 158

placidus, 162

Robinii, 171

rubens, 167

rubens, 169

ruficollis, 165

scutellaris, 176

secalis, 170

suturalis, 159

tristis, 169

Trimorphus, 61

confinis, 62

Erro, 61

scapularis, 62

Zabrus, 115

gibbus, 116

piger, 116

THE END.

PRINTED BY TAYLOR AND FRANCIS, RED LYON COURT, FLEET STREET.

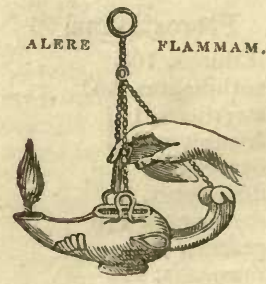





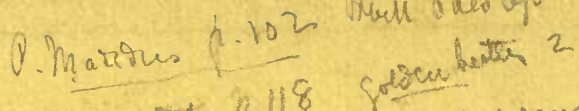

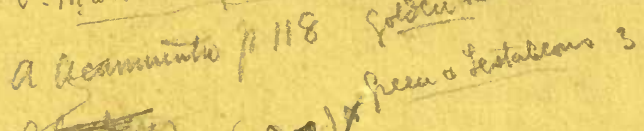

A Omane 83$)_{33}$ sor

Joolecens dic tis 



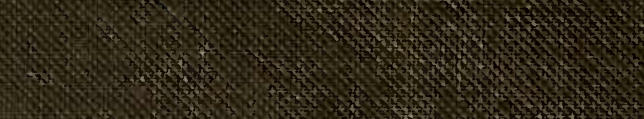

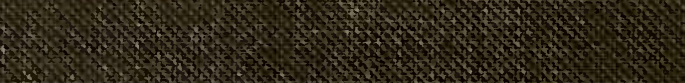

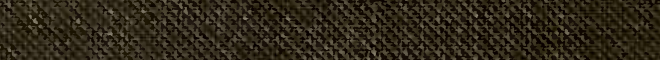

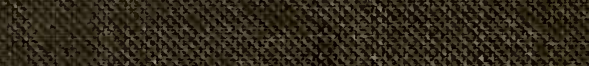

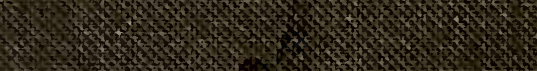

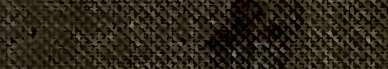

H.

Tht

A

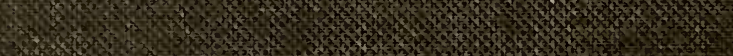

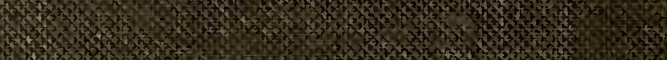

H.t.

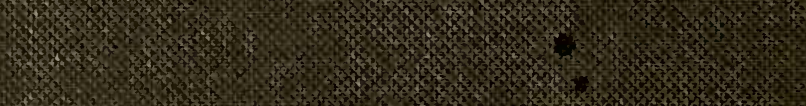

F.

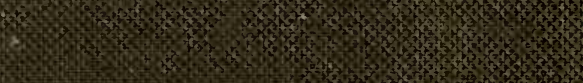

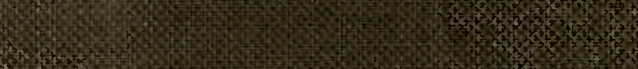

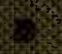

